Міністерство освіти і науки України Київський національний торговельно-економічний університет

\title{
ТЕОРЕТИКО-МЕТОДОЛОГІЧНІ ТРАНСФОРМАЦІЇ ЕКОНОМІЧНОЇ НАУКИ У ХХІ СТ.: ПЕРСПЕКТИВИ НОВОЇ ПАРАДИГМИ
}

\author{
МАТЕРІАЛИ ВСЕУКРАЇНСЬКОЇ \\ НАУКОВО-ПРАКТИЧНОЇ КОНФЕРЕНЦІЇ \\ (Київ, 28-29 травня 2019 року)
}

Київ 2019 


\section{Розповсюдження і тиражування без офіційного дозволу КНТЕУ заборонено}

УДК 330.1-044.922«20»

Теоретико-методологічні трансформації економічної науки у XXI ст. : перспективи нової парадигми: матеріали Всеукр. наук.-практ. конф. (Київ, 28-29 трав. 2019 р.). - Київ : Київ. нац. торг.-екон. ун-т, 2019. - 344 с.

ISBN 978-966-629-939-3

DOI: http://doi.org/10.31617/k.knute.2019-05-29.01

Збірник матеріалів учасників Всеукраїнської науково-практичної конференції «Теоретико-методологічні трансформації економічної науки у XXI ст.: перспективи нової парадигми» присвячений актуальним питанням трансформації економічної науки у XXI ст., питанням інформаційно-знаннєвої, мережевої, сервісної економіки та макро- й мікроекономічним проблемам розвитку сучасності. Матеріали друкуються в авторській редакції. Відповідальність за зміст публікацій та академічну доброчесність несуть автори.

Відповідальний редактор д-р екон. наук, проф., В. Д. Лагутін.

Редакційна колегія: В. Д. Лагутін, д-р екон. наук, проф.; Ю.М. Уманців, д-р екон. наук, проф; А.Г. Герасименко, д-р екон. наук, проф.; Л. В. Лебедева, канд. екон. наук, доц.

Відповідальний за випуск Л. В. Лебедева, канд. екон. наук, доц.

ISBN 978-966-629-939-3 


\section{MICT}

ПЕРЕДМОВА.

НАУКОВИЙ НАПРЯМ 1. ЕВОЛЮЦІЯ МЕТОДОЛОГЇ̈ ДОСЛІДЖЕННЯ В ЕКОНОМІЧНІЙ НАУЦ

Мазаракі А.А.,

ПОТЕНЦІАЛ ПАРАДИГМАЛЬНИХ ТА КОНЦЕПТУАЛЬНИХ ЗМІН В

ЕКОНОМІЧНІЙ НАУЦІ ХХІ СТОЛІТТЯ 12

Артьомова T.I.,

ЦІННІСНІ ЗАСАДИ СТАНОВЛЕННЯ РЕЛЯТИВІСТСЬКОЇ

ЕКОНОМІЧНОЇ НАУКИ 16

Броницька В.В.,

РИЗИКИ ТА ПРОБЛЕМИ СТАНОВЛЕННЯ НОВОЇ ЕКОНОМІЧНОЇ ПАРАДИГМИ

Вертелєва О.В.,

МАТЕМАТИЧНІ МЕТОДИ В ЕКОНОМІЧНІЙ ТЕОРІЇ ХХІ СТОЛІТТЯ

Гриценко АА.,

ГЛОБАЛЬНА НЕСТАБІЛЬНІСТЬ СОЦАЛЬНО-ЕКОНОМІЧНОЇ ДИНАМІКИ ЯК ОБ'ЄКТИВНЕ ПІДГРУНТЯ ПАРАДИГМАЛЬНИХ ЗРУШЕНЬ В ЕКОНОМІЧНІЙ НАУЦІ

Дзюба П. В.,

СУЧАСНА ТЕОРІЯ МІЖНАРОДНОГО ПОРТФЕЛЬНОГО

ІНВЕСТУВАННЯ: БІПАРАДИГМАЛЬНІ ОСНОВИ..._ТА ПЕРСПЕКТИВИ РОЗВИТКУ

Смець В.В.,

ЕВОЛЮЦІЯ МЕТОДОЛГІЇ ДОСЛІДЖЕННЯ ЕКОНОМІЧНОГО ПОНЯТТЯ «НАГРОМАДЖЕННЯ КАПІТАЛУ

Зайцев Ю.К.,

ФІЛОСОФІЯ РОЗВИТКУ ГЛОБАЛЬНОЇ ЕКОНОМІКИ ТА

СУСПІЛЬСТВА В УМОВАХ ЧЕТВЕРТОЇ ПРОМИСЛОВОЇ РЕВОЛЮЦІЇ 
Лагутін В.Д.,

ПЕРСПЕКТИВИ ОНОВЛЕННЯ МЕТОДОЛОГІЇ ЕКОНОМІЧНОЇ НАУКИ У ХХІ СТОЛІТТІ 48

Лебедева Л. В.,

ПРЕДМЕТ ДОСЛІДЖЕННЯ СУЧАСНОЇ ЕКОНОМІЧНОЇ НАУКИ..... 51

Лепак П.А.,

ДОСЛІДЖЕННЯ ЦІННІСНИХ ОРІЄНТИРІВ СУСПІЛЬСТВА, ЗАСОБАМИ WORLD VALUES SERVEY. 56

Максимюк В.А.,

ЕКОНОМІЧНА ТЕОРІЯ 3 ПОГЛЯДУ ФІЗИКИ 60

Мельник Т.М., Кудирко Л.П.,

РЕНЕСАНС ПАРАДИГМИ ПРОТЕКЦІОНІЗМУ В СТРАТЕГІЯХ ІМПОРТОЗАМІЩЕННЯ 66

Москаленко О.М.,

МІЖДИСЦИПЛІНАРНІСТЬ У СУЧАСНІЙ ЕКОНОМІЧНІЙ ТЕОРІЇ: ЧОМУ ЕКОНОМІСТИ ВИХОДЯТЬ ЗА ГЕДОНІСТИЧНІ ІНТЕРПРЕТАЦІЇ ПОВЕДІНКИ?

Ніколаєць К. М.,

ПЕРСПЕКТИВИ РОЗВИТКУ ФУТУРОЛОГІЧНИХ ДОСЛІДЖЕНЬ

НА ПОЧАТКУ ХХІ СТ. 76

Ожелевська Т.С.,

УКРАЇНСЬКИЙ МЕЙНСТРИМ ЕКОНОМІЧНОЇ ТЕОРІЇ: РОЗВИТОК ЧИ ІНСТИТУЦЙНА ПАСТКА?

Осецький В.Л.,

ІМПЕРАТИВИ ОНОВЛЕННЯ МЕТОДОЛОГІЇ ЕКОНОМІЧНОЇ АНАЛІТИКИ 86

Петренко В. П.,

РОЛЬ І ЗАВДАННЯ ЕКОНОМІЧНОЇ НАУКИ У ТРАНСФОРМАЦІЇ ІНСТИТУЦІОНАЛЬНОЇ МАТРИЦІ СУЧАСНОГО УКРАЇНСЬКОГО СУСПІЛЬСТВА 90

Поліванов В.С.,

ПАТЕРНАЛІЗМ ТА ЛІБЕРАЛІЗМ У НОВІЙ ПАРАДИГМІ ЕКОНОМІЧНОÏ СИСТЕМИ 
Романенко В.А.,

ЧИННИКИ ФОРМУВАННЯ ПАРАДИГМИ В ЕКОНОМІЧНІЙ НАУЦІ (ICTOРІЯ І СУЧАСНІСТЬ) 97

Уманців Ю. М.,

ВЗАСМОДІЯ ДЕРЖАВИ ТА РИНКОВИХ МЕХАНІЗМІВ ЗА_УМОВ ГЛОБАЛЬНИХ ТРАНСФОРМАЦІЙ. 100

Філіпенко А.С.,

МІЖДИСЦИПЛІНАРНІСТЬ У ЕКОНОМІЧНІЙ МЕТОДОЛОГІЇ: ФІЛОСОФІЯ, ЛОГІКА, МАТЕМАТИКА..... 104

Хрустальова В.В.,

ПРОБЛЕМИ ПЕСИМІЗМУ ТА ОПТИМІЗМУ У ЕКОНОМІЧНІЇ

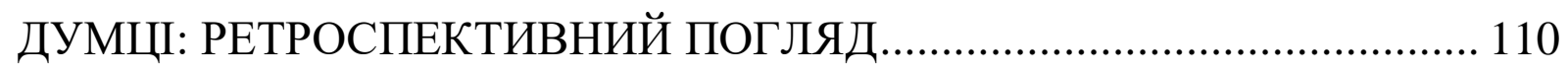

Шевчук В.О.,

ЖИТТССТВЕРДНИЙ СТАТУС ПИТОМО УКРАЇНСЬКОГО ЗНАННЯ: СТАНОВЛЕННЯ ПАРАДИГМИ РЯТІВНОГО ЕКОНОМІЧНОГО МИСЛЕННЯ. 115

Ясько Ю.І.,

ЕВОЛЮЦІЯ ТЕОРЕТИЧНИХ ПОГЛЯДІВ НА РОЛЬ ДЕРЖАВИ В ЕКОНОМІЦІ. 120

НАУКОВИЙ НАПРЯМ 2. ІНФОРМАЦЙНО-ЗНАННЕВА, МЕРЕЖЕВА, СЕРВІСНА ЕКОНОМІКА ХХІ СТ..

Волосович С.В.,

FINTЕСН ЯК ЧИННИК ЗРОСТАННЯ ФІНАНСОВОЇ ІНКЛЮЗИВНОСТІ

Гуменюк В.В.,

ВЕКТОР ВІДПОВІДАЛЬНОГО РОЗВИТКУ_В ДЕРЖАВНОМУ УПРАВЛІННІ ЕКОНОМІКОЮ ЗНАНЬ

Дідківська Л. В.,

ЕМІГРАЦІЯ УКРАЇЦІВ В УМОВАХ СТАНОВЛЕННЯ ЕКОНОМІКИ ЗНАНЬ 130

Лазебна I.B.,

ВПЛИВ МЕРЕЖЕВОЇ ЕКОНОМІКИ НА ЖИТТЯ СУСПІЛЬСТВА.... 133 
Левандівський О.Т., Казюка Н.П.,

МОДЕЛЬ ІНВЕСТУВАННЯ АГРАРНОГО СЕКТОРУ

Ліпін М.В.,

ЗНАЧЕННЯ ТВОЧОСТІ У «КРЕАТИВНІЙ ЕКОНОМІЦІ»

Марченко О. С.,

БІЗНЕС-КОНСАЛТИНГ У СТРУКТУРІ СЕРВІСНОЇ ЕКОНОМІКИ:

ГОЛОВНІ ХАРАКТЕРИСТИКИ ТА ФУНКЦІЇ. 147

Мудла Д.В.,

ТЕОРЕТИЧНІ АСПЕКТИ МЕРЕЖЕВОЇ ЕКОНОМІКИ 151

Носова О.В., Носова Т.Ю.,

ІЄРАРХІЧНІ І МЕРЕЖЕВІ СТРУКТУРИ В ІНСТИТУЦІЙНІЙ

ЕКОНОМІЦІ. 155

Підвисоцький Я. В.

МЕТОДИКА КОНСТРУЮВАННЯ ФІНАНСОВИХ ІННОВАЦІЙ 3

МЕТОЮ УПРАВЛІННЯ ІНВЕСТИЦІЙНИМИ РИЗИКАМИ.................... 160

Прутська O.O.,

СОЦІАЛЬНІ ІНВЕСТИЦІЇ В ПАРАДИГМІ РОЗВИТКУ ЕКОНОМІКИ XXI CT. 164

Романишин В.О., Гавриленко Ю.О.,

СТИМУЛЮВАННЯ ІННОВАЦІЙНОЇ ДІЯЛЬНОСТІ НАЦІОНАЛЬНИХ ПІДПРИЄМСТВ 167

Сливка T.O.,

ОСОБЛИВОСТІ УЧАСТІ МЕРЕЖЕВИХ ФОРМ КОРПОРАТИВНОГО КАПІТАЛУ У МІЖНАРОДНИХ ЛАНЦЮГАХ ДОДАНОЇ ВАРТОСТІ . 171

Стеценко Б.С.,

КОНКУРЕНТНА ПОВЕДІНКА ФІНАНСОВИХ ІНСТИТУЦІЙ В ЕКОНОМІЦІ ЗНАНЬ 176

Уманців Г.В., Мартинів І.К.,

«ІНДУСТРІЯ 4.0» У КОНТЕКСТІ ІНТЕЛЕКТУАЛІЗАЦІЇ ЕКОНОМІЧНОГО РОЗВИТКУ.

Н.В. Ушенко,

ПІДПРИСМНИЦЬКА ТРАНСФОРМАЦІЯ_УНІВЕРСИТЕТІВ УКРАЇНИ 
Штундер I.O.,

IННОВАТИЗАЦІЯ ЗАЙНЯТОСТІ В УМОВАХ ЕКОНОМІЧНИХ ТРАНСФОРМАЦІЙ.

Янчук А.Л.,

НАПРАВЛЕНИЯ ИННОВАЦИОННОГО РАЗВИТИЯ ГОСУДАРСТВ ACEAH

НАУКОВИЙ НАПРЯМ З. МАКРО- ТА МІКРОЕКОНОМІЧНІ ПРОБЛЕМИ РОЗВИТКУ

Бубон Т.В.,

ТАЙМ-МЕНЕДЖМЕНТ ЯК ТЕХНОЛОГІЯ РОЗВИТКУ ОРГАНІЗАЦЇ̈ 196

Весперіс С.3., Самусь Г.І.,

СУЧАСНИЙ СТАН АГРАРНОГО РИНКУ УКРАЇНИ 199

Гаращенко Е.А.,

СООТНОШЕНИЕ ТАРИФНОГО И НЕТАРИФНОГО

РЕГУЛИРОВАНИЯ ВНЕШНЕЙ ТОРГОВЛИ СТРАН. 203

Дугінець Г.В.,

ГЛОБАЛЬНІ ІМПЕРАТИВИ РОЗВИТКУ МІЖНАРОДНИХ ВИРОБНИЧИХ МЕРЕЖ.

Дуцька А. С.,

МІЖНАРОДНІ СТАНДАРТИ ФІНАНСОВОЇ ЗВІТНОСТІ У

КОНТЕКСТІ ПОСИЛЕННЯ КОНКУРЕНТНИХ ПЕРЕВАГ СУБ'ЄКТІВ

ГОСПОДАРЮВАННЯ 211

Дучинська Н.I.,

ДОВІРА ЯК ІНСТИТУЦІЙНИЙ ЧИННИК СОЦАЛЬНО-

ЕКОНОМІЧНОГО РОЗВИТКУ.

Ємельяненко Л. М., Москвіна В.І.,

ТРАНСФЕРТИ В РЕГУЛЮВАННІ_БЮДЖЕТНИХ ВІДНОСИН

СОЦАЛЬНОЇ СФЕРИ

Жаліло Я.А.

УКРАЇНА 2020-2024: ОБГРУНТУВАННЯ СТРАТЕГІЧНИХ IMПЕРАТИВІВ 223 
Катран M.В.,

ПРОБЛЕМИ ЗМІСТУ І МЕТОДИКИ ВИЗНАЧЕННЯ ОБСЯГУ ВНУТРІШНЬОГО РИНКУ

Ю.В. Кіндзерський,

КОНСЬЮМЕРИЗМ ЯК ПРИВНЕСЕНА ІДЕОЛОГІЯ ДЕГРАДАЦІЇ СУСПІЛЬСТВА, ДЕРЖАВИ, ЕКОНОМІКИ: ФЕНОМЕНОЛОГІЯ ПРОЯВУ В УКРАЇНІ

Корнєєва Ю.В.,

КЛАСИФІКАЦІЯ ІНВЕСТИЦІЙ В УКРАЇНІ: ОБЛІКОВИЙ ПІДХІД . 236

Крюкова I.O.,

РОЛЬ ЛОГІСТИКИ У СУЧАСНИХ СВІТОВИХ ТЕНДЕНЦІЯХ ЕКОНОМІЧНОГО РОЗВИТКУ

Kuzmenko V. M.,

FORMATION AND DEVELOPMENT OF INTERNATIONAL PROJECT FINANCE MARKET.

Куліш Л. П.,

ДЕРЖАВНА ПОЛІТИКА ПІДВИЩЕННЯ

КОНКУРЕНТОСПРОМОЖНОСТІ НАЦІОНАЛЬНОЇ ЕКОНОМІКИ ..... 253

Малий І.Й.

КОНВЕРСІЯ ПУБЛІЧНОГО УПРАВЛІННЯ ЕКОНОМІКОЮ В УКРАЇНI 256

Міняйло О.І., Міняйло В.П.,

СТИМУЛЮВАННЯ РОЗВИТКУ МАЛОГО ПІДПРИЕМНИЦТВА В УКРАЇНІ: ФІСКАЛЬНИЙ АСПЕКТ

Павлішина Н.М.,

АДАПТАЦІЯ ЛОГІСТИЧНИХ ПРОЦЕСІВ ДО ЕЛЕКТРОННОЇ ФОРМИ ТОРГІВЛІ 263

Петренко Н.В.

ПРІОРИТЕТНІ НАПРЯМИ ПРОТИДІЇ СИСТЕМНІЙ КОРУПЦІЇ В УКРАЇ̈I 267

Підчоса О.В.

ЗАГАЛЬНИЙ ОГЛЯД ОСНОВНИХ ВИДІВ ТРАНСПОРТНИХ ЗВ'ЯЗКІВ МІЖ ЄВРОПОЮ ТА АЗІЄЮ: РОЛЬ КРАЇН СХІДНОЇ ЄВРОПИ, ЩО НЕ ВХОДЯТЬ ДО ЄС 
Свистільник В.Ю.,

ВПЛИВ ІНФОРМАЦІЙНОЇ АСИМЕТРІЇ НА ДЕФОРМАЦІЮ СПОЖИВЧОГО ПОПИТУ В УКРАЇНІ.

Смагін В.Л.,

МЕТОДОЛОГІЧНЕ ПІДГРУНТЯ ФУНКЦІОНУВАНЯ ФІНАНСОВОГО РИНКУ В УМОВАХ СИСТЕМНИХ ТРАНСФОРМАЦІЙ . 279

Соколова Ю.О.,

РОЗВИТОК РЕГІОНУ В КОНТЕКСТІ КОНЦЕПЦІЇ ІНКЛЮЗИВНОСТІ

Соколовська І.П.,

ПЕРЕДУМОВИ ВІДНОВЛЕННЯ КРЕДИТУВАННЯ ЕКОНОМІКИ УКРАЇНИ

Стратійчук В.M.,

АНАЛІЗ РИНКУ ТУРИСТИЧНИХ ПОСЛУГ УКРАЇНИ 290

Струк Н. П.,

ЯКІСТЬ ЖИТТЯ НАСЕЛЕННЯ: АНАЛІЗ БАЗОВИХ КОМПОНЕНТ. 296

Тетеринец Т.А.,

ПРОБЛЕМЫ РАЗВИТИЯ ЧЕЛОВЕЧЕСКОГО КАПИТАЛА В

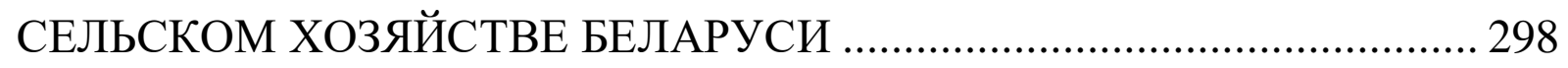

Тищенко О. П.,

ДИСБАЛАНСИ ІНКЛЮЗИВНОГО РОЗВИТКУ ЕКОНОМІКИ

УКРАЇНИ: ОЦІНКА ТА ШЛЯХИ ПОДОЛАННЯ 302

Феняк Л.А.,

СУЧАСНІ ТЕНДЕНЦІЇ РОЗВИТКУ ПІДПРИЄМСТВ ГАЛУЗІ

САДІВНИЦТВА У ВІННИЦЬКІЙ ОБЛАСТІ 307

Хаєцька О.П.,

ЕКОНОМІЧНЕ ЗРОСТАННЯ В УКРАЇНI

Хлопяк С.В.,

ПОЛІТИЧНІ ДЕТЕРМІНАНТИ РОЗВИТКУ МІЖНАРОДНОГО ТУРИЗМУ. 315

Цімболинець Г.І.,

ВПЛИВ СУЧАСНИХ ТА ПРОГНОЗОВАНИХ ТРЕНДІВ ТРУДОВОЇ МІГРАЦІЇ НА ЕКОНОМІЧНІ ПРОЦЕСИ В ЗАКАРПАТСЬКІЙ ОБЛАСТІ 
Черленяк I.I.,

ЕКОНОМІЧНА ВЛАДА ТА ЕВОЛЮЦЙНА ЕФЕКТИВНІСТЬ

ПОЛІТИЧНИХ ЦИКЛІВ В УКРАЇНІ

Шкуропадська Д.Б.,

ФАКТОРИ ЗАБЕЗПЕЧЕННЯ СТІЙКОСТІ ЕКОНОМІКИ

Шкутько О.Н.,

ОБРАБАТЫВАЮЩАЯ ПРОМЫШЛЕННОСТЬ РЕСПУБЛИКИ

БЕЛАРУСЬ: НАПРАВЛЕНИЯ РАЗВИТИЯ И ТОЧКИ РОСТА

Шубін В.Д.,

ДО ПИТАННЯ ФУНКЦІЙ ДЕРЖАВИ ТА ЇХ ФІНАНСОВОГО

ЗАБЕЗПЕЧЕННЯ

Щербакова Т.А.,

СТРАТЕГІЧНІ ПРІОРИТЕТИ НАЦІОНАЛЬНОЇ ЕКОНОМІКИ_В УМОВАХ ГЛОБАЛІЗАЦІї. 


\section{ПЕРЕДМОВА}

У сучасному суспільстві складних соціально-економічних систем, 3 економікою, що постійно змінюється, економічна наука повинна динамічно розвиватися аби відповідати поточним викликам. Саме обговоренню питань трансформації економічної науки, пошуку нової парадигми іiі розвитку й присвячена Всеукраїнська науково-практична конференція «Теоретико-методологічні трансформації економічної науки у XXI ст.: перспективи нової парадигми».

У матеріалах конференції висвітлені методологічні аспекти трансформації економічної науки, питання інформаційно-знаннєвої, мережевої, сервісної економіки XXI ст. та макро- й мікроекономічні проблеми розвитку сучасності. Суттєва увага приділяється питанням методології економічної науки, глобальній нестабільності макроекономічної динаміки та іiі висвітленню в економічній думці, економічному розвитку в умовах четвертої промислової революції, сучасним проблемам економічного розвитку в інформаційномережевій економіці та іншим проблемам макро- та мікроекономічного розвитку.

Матеріали Всеукраїнської науково-практичної конференції «Теоретико-методологічні трансформації економічної науки у XXI ст.: перспективи нової парадигми» будуть корисними для всіх учасників заходу і читачів, які цікавляться сучасними проблемами теоретикометодологічних трансформацій економічної науки. 


\section{НАУКОВИЙ НАПРЯМ 1. ЕВОЛЮЦІЯ МЕТОДОЛОГІЇ ДОСЛІДЖЕННЯ В ЕКОНОМІЧНІЙ НАУЦІ}

Мазаракі А.А., д.е.н., професор, Київський національний торговельноекономічний університет

\section{ПОТЕНЦАЛ ПАРАДИГМАЛЬНИХ ТА КОНЦЕПТУАЛЬНИХ ЗМІН В ЕКОНОМІЧНІЙ НАУЦІ ХХІ СТОЛІТТЯ}

Наявність парадигми - необхідна форма існування і розвитку науки. Прагнення і досягнення істини на основі об'єктивного дослідження, і відкритого неупередженого дискурсу можливе лише шляхом дотримання дослідниками певних парадигмальних принципів i підходів. Сформована парадигма закономірно спрямовує логіку мислення дослідників, які пізнають предмет науки. Поняття парадигми тісно корелює із поняттям мейстриму науки.

Враховуючи багатогранність поняття «парадигма» слід виокремлювати ряд іiі типів на основі критеріального застосування трьох фундаментальних категоріальних планів: онтологічного, гноселогічного i аксіологічного. Онтологічна парадигма, або парадигма буття відображає центральний пріоритетний вектор розвитку економіки. Гносеологічна парадигма, або парадигма власне науки вказує на концептуальну єдність досліджень для переважної більшості представників економічної науки. Аксіологічна парадигма, або парадигма цінностей, у крайній формі - ідеології, відображає загальновизнану ціннісну систему, якої притримується наука. Найгірший варіант тут коли економічна наука фактично перетворюється на ідеологію, тобто починає виконувати роль засобу обслуговування інтересів політичної владної еліти.

Наукова парадигма вибудовує систему логічних зв'язків i категорій, а також обгрунтовує засоби зіставлень їх 3 економічною реальністю. Ідеологічна парадигма базується на ціннісній аксіоматиці, 3 якої можна погоджуватися або не погоджуватися, говорити про іiі обмеженість, але все ж в цілому застосовувати іiї в дослідницьких програмах. Різні типи парадигм пов'язані між собою. Коли гносеологічна парадигма стає непорушною та незаперечною, то існує загроза, що вона дійсно може перетворитися на ідеологію, тобто 
починає наполягати на вірі у власну непогрішність i моральну виправданість.

Важливе значення сьогодні мають парадигмальні та концептуальні новації в економічній науці. Наукове осмислення сутності сучасних економічних відносин вимагає застосування в дослідженнях оновленої парадигми. 3 приводу еволюції парадигм T. Кун зазначав, що вони можуть і повинні конкретизуватись в умовах, що змінюються. Успіх нової парадигми полягає у перспективах науки щодо вирішення нових проблем, а також розширення знань про факти об'єктивної дійсності [1]. Оновлення парадигми означає, що в науці розвиваються інші (порівняно з тими, що існували до цього) теоретикометодологічні засади дослідження об'єктивної дійсності.

На нашу думку, сучасна економічна наука перебуває в пошуку нової парадигми. Глобальна фінансово-економічна криза 2008-2009 рр. наочно продемонструвала суперечливість i неефективність нормативних наслідків ортодоксальної неокласичної парадигми 3 iї численними методологічними припущеннями (спрощеннями).

Розбудова нової парадигми економічної теорії бачиться на шляху відходу від неокласичних моделей, забезпечення активного пошуку гетеродоксальних концептуальних схем за межами мейнстріму. Однак чи є сьогодні такі концепції (концептуальні моделі)? Вважаємо, що таких загальновизнаних концепцій не може бути доти, поки остаточно не сформується нова економічна система XXI ст. Інша справа, що змістовні моменти нової наукової парадигми складаються вже сьогодні i ïx можна осмислювати i використовувати хоча б частинами й фрагментарно.

Постає питання: наскільки адекватно сьогодні наукові концепції в економічній науці відображають економічну реальність? Наша відповідь: в цілому, неадекватно. I проблема не лише в стані самої науки, а в масштабній трансформації економіки XXI ст. Неокласична наукова парадигма існує, в т. ч. й у нас в Україні (якби ми її не критикували), але знаходиться "в русі". До чого в підсумку ми прийдемо, наприклад, в 2050 р. чи 2070 р. сказати складно. Поки, важливо фіксувати зміни, тренди зрушень, бачити новації які відбуваються в теоретико-методологічному базисі науці.

Думається, що серед гетеродоксальних наукових напрямків, які претендують на статус нової парадигми, основним слід розглядати інституціоналізм. Інституціональна теорія має найвищий потенціал щодо оновлення парадигми економічної науки. Проте існує загроза, що інституціоналізм 3 часом може інтегруватися в ортодоксальний 
мейнстрім. Тим більше, що цей процес інтеграції відбувається уже сьогодні.

У XX ст. було кілька спроб кардинальної зміни парадигми економічної теорії. У 1940-1970-х рр.; коли на роль наукової парадигми претендувала неокейнсіанська макроекономічна концепція (кейнсіанська революція). Зауважимо тут, що на думку Й. Шумпетера, хоча Дж. М. Кейнс театрально відмовлявся від своєї прихильності до школи А. Маршала (читай - неокласиці) «він ніколи не відхилявся від маршаліанської лінії більше, ніж це було необхідно для його аргументації» [2, Р. 353]. У 1920-1980-х рр.: коли на роль аксіологічною парадигми реально претендувала марксистськоленінська теорія. Проте 3 розпадом СРСР марксистська модель ціннісно-ідеологічної парадигми економічної науки втратила свою значущість.

Можливий шлях вирішення проблеми парадигмальних та концептуальних змін в економічній науці XXI ст. - не заміна однієї парадигм на іншу, а досягнення міжпарадигмального компромісу. При цьому виникає потреба у виході за межі дискурсу між різними парадигмами економічної науки (так званого парадигмального глухого кута). Приклад - концепція неокласичного синтезу 1960-1970-х рр. (зокрема ідеї П. Самуельсона).

Сучасна парадигма економічної теорії - продукт розвитку передової західної цивілізації, яка зуміла осмислити еволюцію ринкової економічної системи XVIII - XX ст. у всій іiї суперечливості і неоднозначності. Безумовно, ця неокласична та ліберальна парадигма універсальна і $є$ реально корисною при осмисленні економічних систем усіх країн світу. Інша справа, що наукове дослідження національної економічної системи повинно бути, насамперед, результатом рефлексії економічної науки цієї країни. Думається, що механічне копіювання «чужих», хоча й універсальних теорій не дає повноцінного позитивного результату.

Який внесок може внести (і чи це взагалі реально) українська економічна наука в загальносвітову? Вітчизняна наука може бути багата відкриттями і формуванням нових наукових напрямів. В даному випадку корисними будуть, наприклад, дослідження за такими напрямами: в макроекономіці - малі відкриті економіки, макроекономічна нестабільність; в мікроекономіці - ринкова нерівновага, турбулентність конкурентного середовища, ринкова модель поведінки «бідного» споживача; в інституціональній теорії зміст та форми прояву низької якості інститутів, механізм підвищення ефективності інститутів, специфіка інституційних змін в економіках 3 
ринками, що розвиваються та ін. Вищенаведений перелік далеко невичерпний. Проте, очевидним є й той факт, що будь-якого роду "провінційність" («хуторянство»), тобто звернення виключно до місцевих проблем без урахування загальносвітових трендів тупиковий шлях розвитку української економічної науки.

Актуальною $\epsilon$ методологічна проблема демаркації за $\mathrm{K}$. Поппером, тобто розмежування науки і псевдонауки. Науковість теорії (концепції) виявляється в процесі дискурсу, а також на основі перевірки емпіричними (фактичними) даними. Йдеться про так званий принцип фальсифікаціонізму. Якщо теорія не фальсифікується фактичними даними, вона вважається науковою і визнаною (що доводиться на основі дискурсу) дослідницьким співтовариством [3].

Основою дійсних наукових досліджень завжди була i $\epsilon$ методологічна тріада: «об'єктивна дійсність» - «неупереджений аналіз» - «достовірні результати». Псевдонауковість досліджень формує хибний трикутник «викривлена (фейкова) дійсність» «недоброчесність в аналізі» - «маніпулятивні результати». Як підсумок - дезорієнтація суспільства як генерального кінцевого споживача наукових досліджень, викривлення суспільних уявлень про економіку та економічні відносини.

Легкодоступна інтернетівська інформація дає можливість псевдонауковцям перетворювати тривалий та важкий процес наукового дослідження у простір плагіаторства і наукового нігілізму. Етика академічної недоброчесності виявилася надзвичайно агресивною, що не могло не применшити суспільну значущість позицій справжніх науковців. Доброчесність тих, хто генерує релевантну наукову інформацію повинна бути вирішальною i найважливішою.

У цілому зрозуміло, що насамперед фаховий рівень та академічна доброчесність дослідників $є$ надійною основою належної науковості проведення досліджень. Низький фаховий рівень та академічна недоброчесність - прямий шлях до деградації нашої науки.

Потенціальні можливості формування нової наукової парадигми не проявлятимуться доти, поки не з'являться відповідні для цього суспільні умови. Йдеться про суспільну затребуваність нової парадигми економічної науки. Якщо така затребуваність відсутня, зусилля лише окремих груп науковців внести якісь парадигмальні зміни в економічну науку будуть в кращому випадку подібні лише на зовнішнє косметичне «оновлення» парадигми. 


\section{Список використаних джерел}

1. Kuhn T. The Structure of Scientific Revolutions, 2 nd ed. - Chicago: University of Chicago Press, 1970. - P. 121-143.

2. Schumpeter J. Science and Ideology// American Economic Review. 1949. Vol. 39 No. 2. - P. 345-359.

3. Popper K. Science: Conjectures and Refutations // K. Popper Conjectures and Refutations: The Growth of Scientific Knowledge. -London: Routledge, 1969. - P. 33-65.

Артьомова T.I.,

д. е. н., доцент, ДУ « Інститут економіки

та прогнозування НАН України»

\section{ЦІННІСНІ ЗАСАДИ СТАНОВЛЕННЯ РЕЛЯТИВІСТСЬКОӤ ЕКОНОМГЧНОЇ НАУКИ}

Становлення інформаційного суспільства 3 осередком у формі мережевої економіки ознаменувало початок глобальної ціннісної модифікації системи економічних відносин і законів. В умовах масового подрібнення ціннісних поглядів, поширення феноменів символічної цінності явища економічної процесуальності стають все більш непередбачуваними. Характер зазначених явищ 3 усією очевидністю було продемонстровано у ході глобальної фінансовоекономічної кризи, руйнівні наслідки якої не подолано й досі. Наростання явищ соціально-економічної процесуальності й невизначеності господарських перспектив актуалізувало проблему суспільного вибору, а разом з нею і глобальний соціальний запит на формування принципово нової логічної парадигми суспільного буття в усіх його проявах. Наполегливо заявила про себе потреба соціальноекономічного осмислення теорії відносності. Адекватною відповіддю на вказаний запит $\epsilon$ формування релятивістської соціальноекономічної теорії, здатної відобразити генезис та історичні долі свого об'єкта як складного багатовимірного утворення в єдиній просторовочасовій системі координат, яка містить передумови й можливості багаторівневого вибору суб'єктів у вірогідному діапазоні від абсолютної випадковості до жорсткої детермінації .

При цьому релятивістська економічна парадигма повинна забезпечити не просто споглядальне світосприйняття, але діяльний 
(перетворювальний) світогляд для господарюючих суб'єктів, тобто висвітлити передумови та обгрунтувати механізми трансформування усього різноманіття варіантів можливого соціально-економічного вибору до русла керованої процесуальності, що відображає, як сказав би К. Поппер, «взаємопов'язану систему з хмар і годинників, в якій навіть найкращі годинники в своїй молекулярній структурі виявляються хмароподібними». Дійсно, абсолютна свобода вибору, так само як і жорстка причинно-наслідкова його детермінація є лише граничними варіантами (законами) розвитку складних систем. Тільки у своєму проміжному, взаємно перетікаючому, відносному становищі вони можуть бути адекватно відображені логікою пізнання, що не зводиться до імовірнісних уявлень і розкриває шляхи конструювання гармонійного порядку 3 хаосу, на яких знімається сама проблема вибору і супутній їй стан невизначеності господарських перспектив. Логіку Серединного шляху як русло, що пролягає між двома крайніми (граничними) підходами, кожен 3 яких символізує відчуження, «концепцією світу, керованого законами, що не залишають місця для новації і творчості, і концепцією ... абсурдного, акаузального світу , в якому нічого не можна зрозуміти» [1, с.216], покликана сьогодні сформувати політична економія за допомогою теорії економічної цінності.

Загальнометодологічний статус теорї економічної цінності у вузькому (у системі економічних наук) і широкому (як ядра філософії господарства) розумінні обумовлюється трансиендентною сутністю поняття і відносин економічної иінності як блага, єдиного в троїстій визначеності граничної корисності, вартості $i$ ичіни [2, с. 11]. Основоположним інститутом економічної цінності $\epsilon$ ціна. Відображаючи взаємне перетікання відносин вартості (буття економічного часу) і граничної корисності (буття економічного простору), інститут ціни виступає генетичної одиницею господарської системи, що здатна ефективно синтезувати, зберігати і транслювати соціально-економічну інформацію, забезпечуючи підпорядкування механізму сукупного суспільного відтворення законам економічної ефективності та соціальної справедливості. Економічне благо (цінність) як інститут, таким чином, в згорнутому вигляді містить у собі не тільки суто економічну, а й соціальну складову суспільного господарського організму (універсуму). Інститут ціни є умовою, змістом, результатом і мірою економічного вибору господарюючих суб'єктів у системі природа - людина - суспільство, що об'єднує природно-економічні, організаційно-економічні та соціальноекономічні відносини й зв'язки. Будь-який індивідуальний вибір у такій 
системі є лише елементом суспільного вибору і в згорнутому вигляді містить у собі (у своїй ціннісній генетичній пам'яті) всю історичну спадщину минулого вибору, а в ціннісних очікуваннях - усе різноманіття варіантів майбутнього вибору. Ціна вибору $\epsilon$ багатоосмисленою і прояснюється в ході взаємодії цінностей, норм i оцінок, що відображає взаємозв'язок вибору цілей і засобів реалізації господарської діяльності в умовах економічних альтернатив.

Інститут вибору фокусує ціннісні відносини, об'єднуючи економічну цінність з усіма іншими iї формами та проявами, а, отже, закладає засади для формування цілісної інституційної картини світу. Ціннісне підгрунтя вибору врешті-решт виводить його за межі економічного, буття сущого і націлює на Вище благо, вищий вибір, вибір духовний .

Витоки ціннісної методології як способу гармонійного світосприйняття і світооблаштування криються в первісному суспільстві; іiі засади були закладені філософами античності і розвинені теологами середньовіччя. У найзагальнішому вигляді ціннісна методологія є рефлексією (від пізньолатинської reflexio - «звернення назад»), логікою пізнання об'єкту, законів його функціонування i розвитку через самопізнання діяльного господарюючого суб'єкту в системі координат природа - людина - суспільство. Це самоспостереження через вихід за власні межі, подолання власного «я»; самозбагнення, що спрямоване назовні і обумовлює сходження до Вищого блага. В умовах, коли економіка не відігравала визначальної ролі у формуванні системи відносин та інститутів господарського організму суспільства, теорія цінності розвивалася переважно зусиллями філософії і теології. 3 часом економічні відносини в системі суспільного господарювання набувають загального характеру, а вартість утворює зміст цільової функції цієї системи. Одночасно повноваження в поясненні ціннісних механізмів функціонування i розвитку суспільного господарства переходять до економічної теорії. Наступність ціннісної методології в працях В. Петті, А. Сміта, Д. Рікардо дозволила цим авторам сформувати логіку Серединного шляху - класичне русло течії економічної думки, що відображає методологію перетворених економічних форм .

Протягом XX століття в розвитку економічної науки позначилися дві протилежні тенденції, що обумовили іiі дослідницькі можливості і статус в суспільстві на початок XXI століття. 3 одного боку, тут були сформовані теоретичні засади моделі загальної економічної рівноваги $i$ сталого розвитку системи суспільного господарства. Наприкінці XX століття ця модель переросла вузькі 
рамки локальної теоретичної концепції і набула глобального значення, по-перше, як інтегративна (міждисциплінарна) парадигма, по-друге як ідейна платформа для обгрунтування умов рівноважного функціонування і сталого розвитку глобального господарюючого соціуму (універсуму). Одночасно статусу провідної наукової доктрини набула економічна теорія в цілому. 3 іншого боку, иіннісний розкол методологічного ядра економічної науки, щзо позначився в XIX столітті, у другій половині XX століття досяг свого апогею. Системно «замкнені» абсолютно трудова теорія вартості та маржинальна доктрина неокласичного синтезу остаточно відійшли від логіки Серединного шляху, спровокувавши кризу економічної теорії та iii загальнометодологічну неспроможність. Відхід основоположних гілок економічної науки від логіки Серединного шляху мав не тільки умоглядні теоретичні наслідки; він відобразив і ознаменував феномен «суб'єктивізації» ринкової ціни під впливом діяльності підприємництва, великого бізнесу, держави. Інструментальне ставлення до ціни як знаряддя реалізації корисливих цілей господарюючих суб'єктів, вихолощування іiї трансцендентної сутності за допомогою політики господарської монополії та економічної демократії обумовили ціннісну деградацію самих суб'єктів.

Проте, ціннісна методологія сьогодні не зникла i не девальвувалася. Методологічну наступність зі спадщиною класичної політичної економії можна чітко спостерігати в працях А. Маршалла, Й. Шумпетера, Ф. Найта, Дж. Кейнса, П. Сраффи, Дж. Робінсон, Дж. Гелбрейта. Незважаючи на те, що ідеї, підходи, концепції цих та інших авторів сьогодні «приховані на задвірках» офіційно пануючої маржинальної доктрини i розглядаються тут як доповнення до теоретичної конструкції неокласичного синтезу, саме вони забезпечували справжні наукові дослідження та творчі «прориви» в економічній теорії протягом XX століття. У 1960-ті роки в надрах логіки Серединного шляху сформувалася нова модель економічної рівноваги. Ця модель як форма реалізації рікардіанської ідеї незмінної міри економічної цінності, свого часу передбаченої А. Смітом, була розгорнута в концепції стандартного товару П. Сраффи, яка методологічно поєднала трудову теорію вартості, загальну теорію зайнятості, відсотка і грошей, модель загальної економічної рівноваги, інституційну теорію ціни - тобто практично всю теоретичну економічну науку в єдності іiі маржинального, вартісного та інституціонального підходів. Модель стандартного товару можна вважати одним з найважливіших наукових досягнень XX ст. на шляху прояснення соціально-економічних засад теорії відносності. Проте, 
переважно з ідеологічних причин, концепція П. Сраффи тривалий час була прихованою для ретельного дослідження i до сьогодні не отримала адекватного осмислення і гідного розвитку в економічній науці.

Розмивання рівноважних підвалин господарської системи сьогодні триває, воно відбувається внаслідок модифікації механізмів ринкового ціноутворення. Глобальний виклик буття полягає в тому, що світовий господарський соціум (універсум) знаходиться в точці біфуркації. В умовах свавілля і хаосу, покладаючись виключно на закони економічної самоорганізації, людство не може зробити глобальний вибір на користь життя. Новий господарський порядок не може бути сформований традиційними методами, він повинен будуватися з урахуванням зміни цільової функції економічної системи, колективними зусиллями на основі відносин доброї волі і довіри між суб'єктами усіх рівнів господарювання. Методологічне обгрунтування такого порядку 3 необхідністю вимагає відновлення логіки Серединного шляху через:

a) подолання наукових амбіцій представниками трьох найвпливовіших економічних шкіл (теорії трудової вартості, маржиналізму, інституціональної економіки), а отже, ідеологічної неприязні і відчуження між ціннісними підходами у дослідженнях;

б) методологічну «чистку» ціннісного ядра кожної з названих шкіл, звільнення теорії вартості, граничної корисності і ціни від сформованих у минулому стереотипів їх розуміння;

в) відродження теорії вартості і ціни на об'єднуючій платформі економічної цінності (блага) як теорії буття економічного просторучасу.

Логіко-історичний процес формоутворення економічної цінності $\epsilon$ актуальним, бо він $є$ одночасно «розгортанням історії у сучасність», a отже, становить серцевину теорії перехідної економіки i процесуальності взагалі. Відтворюючи і аналізуючи цей процес, політична економія здатна сформувати передумови нового світорозуміння і світоустрою.

\section{Список використаних джерел}

1. Пригожин И., Стенгерс И. Время, хаос, квант. К решению парадокса времени. - М.: Прогресс, 1999.

2. Артемова Т. И. Стоимость и цена: логико-исторический процесс формообразования. - К.: Основа, 2006. 
Броницька В.В., к.е.н., доцент, Київський національний торговельноекономічний університет

\section{РИЗИКИ ТА ПРОБЛЕМИ СТАНОВЛЕННЯ НОВОЇ ЕКОНОМІЧНОЇ ПАРАДИГМИ}

На початку XXI століття економічна наука переживає, мабуть, найбільш затяжну та глибоку кризу, що актуалізує становлення нової наукової парадигми. Пошук варіантів парадигмальних змін економічної науки адекватних реаліям світу, що глобалізується, відбувається в умовах прискореного накопичення протиріч i багатовекторних змін.

Для того, щоб окреслити риси нової економічної парадигми, необхідно звернути увагу на ті аспекти, що суттєво змінилися в світі, а також на ризики формування нової парадигми, враховуючи головні сучасні тренди. По-перше, глобалізація на даному етапі розвитку світової економіки все більш приймає форму глобалізму ТНК, що призводить до згортання ролі держави та передачі частки іiі управлінсько-регуляторних функцій до наддержавних, транснаціональних структур. Ця проблема ще недостатньо проаналізована сучасною економічною теорією. За інерцією іiі певні напрямки, зокрема й ті, що належать до сучасного мейнстріму, відводять державі традиційну роль.

Мінливість, невизначеність, перманентні ризики - риси сучасного світу, в якому повинна формуватися нова економічна парадигма, роблять цю задачу ще більш складною.

Наступний серйозний момент, пов'язаний 3 посиленням ідеологічного диктату, що створює додаткові труднощі для формування дійсно відповідної сучасним та майбутнім реаліям, практично-орієнтованої парадигми.

Адам Сміт свого часу, формулюючи трудову теорію вартості, був абсолютно не зацікавлений у зміні існуючого стану речей, але в своїх працях відображав те, що вважав за істину, не йдучи проти совісті вченого. В сучасних умовах вчені не є незалежними, що не означає, що ніхто чесно не може створювати соціально-корисне знання, але ступінь розповсюдження, популяризації теорії, матеріальна винагорода, ресурси для творчості, кар'єра залежать від ідеологічної адаптованості теорій до економічної політики, яку формують суб'єкти транснаціонального капіталу. 
Звідси - ще один суттєвий момент. Вчені-економісти не $\epsilon$ суб'єктами економічної політики, чи, можуть бути її суб'єктами лише в межах коридору, що визначається справжніми суб' єкти економічної політики. Відповідно, парадигма, що має бути практично орієнтованою, слугувати базою для формування економічної політики та прийняття вірних економічних рішень, не може сформуватися як цілісне всезагальне знання у сучасних умовах, бо можливість змінити певні фактори, вплинути на них - у вчених майже відсутня. Можливо створити парадигму, в якій будуть максимально реально відображені, проаналізовані та систематизовані сучасні процеси, але, при цьому, звернення до суб'єктів державного управління, коли держава втрачає суб'єктність - профанація, а звернення до наднаціональних структур, що реально впливають на характер глобалізації - неможливо, як в силу їх невизначеності, так й в силу їх власного вектору визначення змін світової системи, який може суперечити інтересам суспільства. Суб'єкт, на якого вчений ще може вплинути, це - населення, але практичні рекомендації переважної більшості наукових робот адресують рекомендації виключно органам місцевого самоврядування, що не $є$ незалежними, та державним органам влади, ігноруючи «низи», в той час, коли, саме, через самоорганізацію населення, створення нових форм соціальної творчості і можливі варіанти адаптації до мінливих, ризикованих умов сучасної економіки, що глобалізується.

Це, до речі, створює ситуацію, коли незаангажоване знання витісняється 3 наукової сфери до популярної літератури, в якій можливо відкрито визнавати наявний стан речей. Об'єктивні ризики формування нової парадигми стосуються внутрішньої потенції науки, що від архаїчного, але цілісного стану, по мірі розвитку після модерну, приходить до дрібнення, формування значної кількості течій, яким притаманні окремі предмети, власні предметні поля, особливі понятійні апарати, специфічна термінологія, причому часто пов'язати такі поняття, використати в іншому предметному полі неможливо. Все це вимагає створення універсальної парадигми, в якій предметні поля можуть мати площину взаємопереходу, і накопичений досвід кожної галузі економічної науки може бути використаний іншою. В ідеалі - не лише економічною наукою, а іншими різноманітними сферами знання.

Але, не зважаючи на дуже складні, мінливі умови, в яких доводиться формувати наукове знання, є немало досягнень, в сфері розробки нової парадигми економічної науки, зокрема такі розробки проводять А. Гриценко [1], [2], В. Базилевич [3], В. Лагутін [4], О. Субетто [5], В. Тарасевич [6], [7], та інші. 
Для ноосферізації сучасної науки необхідно відмовитися від соціально-економічного детермінізму i вписати суспільство в біосферно-ноосферні процеси, велику логіку соціобіосферноноосферної еволюції. Можливість збереження цінності марксистської матеріалістичної діалектики доповнюючи іï синтезом природного технічного і соціального знання пропонує А. Субетто, вписуючи малу логіку соціальної еволюції в більшу логіку - соціоприродну. Ноосферна парадигма отримала у нього найбільший розвиток. Універсоміка В. Тарасевича побудована на схожих принципах. Синтез існує як результат пошуку пропорційності частин цілого і одночасно між частиною i цілим. Це дві сторони єдиного процесу. Голографічність, як один з універсумних принципів побудови всесвіту, знаходить все більшу кількість доказів різних наук, і економічна парадигма не може не враховувати цього. Економічна метафізика В. Базилевича i В. Ільїна значною мірою відповідає цілісному, інтегральному розуміння парадигми.

Загальні процеси ноосферизації, інтеграції та синтезу знань для оновлення парадигми економічної науки можуть сприяти не тільки іiі проривній цілісній розробці, але й поступовому синтезу наукових знань: попарно-психологічна політекономія, екологічна політекономія тощо. Але найбільш значний потенціал нами вбачається саме у ноосферної політекономії, ноосферної філософії господарства.

Загальні ж принципи творення нової парадигми, на наш погляд, такі: максимальне використання потенціалу космізму і ноосферізму, не вибір між різними несуперечливими, але не дуже пов'язаними між собою теоріями, а максимальне вписування їх в більш цілісну світоглядну конструкцію. Загальні принципи нового знання, недоліки знання постмодерну і навіть модерну, визначив видатний вчений О. Панарін: «Сучасний глобальна екологічна криза вимагає кардинального методологічного перевороту: знання про загальне (про загальні основи буття тих чи інших об'єктів) повинно передувати процедурам використання тих чи інших речей. Іншими словами, для того, щоб зберегти унікальні властивості біоценози, треба незрівнянно більше знати про світ, ніж це потрібно для того, щоб поставити на службу нам окремі корисні - в короткостроковій перспективі властивості речей. Збереження знання, яке належить прискорено напрацьовувати людству, вимагає незрівнянно більшої фундаментальної глибини, ніж колишнє, перетворене, проектне знання» [8, с. 182].

Має сенс нову соціально-економічну парадигму формувати відразу із новою глобальною світоглядною науковою епістемою, що 
включає в себе багато несуперечливих між собою парадигм. Для цих цілей можливою ключовою темою може стати духовне виробництво, оскільки воно зараз визначає соціально-економічний, політичний, історичний, соціокультурний розвиток світу. Більш того, крім соціально-економічного змісту воно має в собі всю сукупність духовно-інтелектуальних аспектів, будучи предметом дослідження i творення багатьох областей знань. По суті, для дослідження духовного виробництва найбільш застосовні інтегральні, комплексні знання постнекласичної науки з іiі інтуїтивним навантаженням і холізмом. В свою чергу, якщо духовне виробництво може стати інтегральною базою розробки не тільки нової парадигми, а й епістеми, що включає в себе багато несуперечливих парадигм, то це вимагає інтегральної методології й інтегральних категорій. Що стосується останнього категорії, що застосовуються різними науками мають різні значення, що суттєво ускладнює синтез різних областей знань. Якщо в різних науках використовувати категорії, які можуть бути приведені до єдиного розуміння, синтез єдиного знання здійснюється значно легше. На наш погляд, однією $з$ таких інтегральних категорій є інформація. При виробленні адекватного розуміння цієї дефініції в соціальноекономічному аналізі, значно простіше структурується духовне виробництво, правильно аналізуються багато, зовні однорідних, але внутрішньо суперечливих соціально-економічних процесів. Крім цього, хоча «інформація» сама по собі інтегральна категорія, але використовуються в більшості випадків різні ії значення в філософії, кібернетиці, соціально-економічному аналізі. «Інформація» або інші інтегральні категорії, що застосовуються в різних областях знань можуть, природно і мати свою специфіку в залежності від предмета i специфіки досліджень, однак, крім цього, вони мають ту універсальну частина змісту, прочитання якої трактується однаково в різних наукових системах. Це невід'ємний елемент творення нової економічної парадигми, що формується в умовах глобалізації.

\section{Список використаних джерел}

1. Гриценко А. Методологічні основи модернізації України / А. Гриценко // Економіка України. - 2011. - № 2. - С. 13-27.

2. Гриценко А.А. Фундаментальные и актуальные основания обновления классической политической экономики / А.А. Гриценко // Горизонты экономики. - 2012. - № 2. - С. 45-58.

3. Базилевич В.Д. Метафізика економіки / В.Д. Базилевич, В.В. Ільїн. - К.: Знання, 2007. -718 с. 
4. Лагутін В. Можливості інституційного аналізу суспільної стабільності та розвитку // Вісник КНТЕУ: науковий журнал, 2018. №3 (119). - С. 37-52.

5. Субетто А.И. Мировой экономический кризис как начало исторического краха глобальной капиталистической системы и перехода человечества к ноосферному социализму / А.И. Субетто // Социальная экономика. - 2010. - №1 - С. 34-54.

6. Тарасевич В. Ідеологічні доктрини: Цивілізаційні аспекти та національний колорит / В. Тарасевич // Економіка України. - 2011. - № 2. - C. 13-27.

7. Тарасевич В.Н. Об экономическом научном и универсумном знании / В.Н. Тарасевич // Социальная экономика. - 2010. - № 1. - С. 25-34.

8. Панарин А. Правда железного занавеса [монография] / А. Панарин. - М.: Алгоритм, 2006. -336 с.

Вертелєва О.В.,

к. ф.-м. н., доцент,

Київський національний торговельно- економічний університет

\section{МАТЕМАТИЧНІ МЕТОДИ В ЕКОНОМІЧНІЙ ТЕОРІЇ ХХІ СТОЛІТТЯ}

Сучасні мегатренди економічного розвитку та зміна економічної парадигми, що нині відбувається, призводять до необхідності переосмислення, серед усього іншого, і можливостей, доцільності та перспектив застосування математичних методів при дослідженнях економічних явищ та систем, які постійно видозмінюються i трансформуються під впливом глобалізації, науково-технічного прогресу, інформатизації, а також ментальної та духовної еволюції людини, іiі світосприйняття і економічної поведінки.

Традиційно прийнято вважати, що початок процесу математизації економіки було покладено у 1758 р. публікацією економічних таблиць доктора Ф. Кене та розробками I. Тюнена, який у 1826 р. запропонував модель державного господарства, що 
дозволило в подальшому сформулювати поняття виробничої функції. Більш складна економічна модель, в якій було вперше використано кількісні методи для аналізу конкуренції на дуопольному ринку, була запропонована О. Курно у 1838 p. Пізніше математична інтерпретація економічних явищ лягла в основу наукових доробок Лозанської школи маржиналізму, започаткованої Л. Вальрасом, та Англійської наукової школи маржиналізму під проводом С. Джевонса (кінець XIX ст.).

$\mathrm{XX}$ століття без перебільшення ознаменувало розквіт та бурхливе застосування математичних методів в економіці. До найвідоміших досягнень початку XX століття у цій сфері можна віднести праці американського математика Ч. Кобба та економіста П. Дугласа, які у 1928 р. вперше на підставі статистичних даних зробили спробу встановити залежність між обсягом залученого капіталу та трудових ресурсів і обсягом виробленої продукції, запропоновану у 1928 р. В Рамсеєм модель довгострокового росту економіки, розроблену у 1932 р. Джоном фон Нейманом багатосекторну модель розширеної економіки, появу у 1936 р. моделі міжгалузевого балансу В.В. Леонтьєва, праці одного 3 перших фахівців у галузі економіко-математичних досліджень у радянський період А.А. Конюса, присвячені, зокрема, проблемам оцінювання індексу вартості життя (1924р.). Історичну роль у розвитку економіко-математичної теорії цього періоду відіграли праці Є. Слуцького, Дж. Хікса, відомого українського ученого М. ТуганБарановського та ін.

Якщо дослідження окремих економічних проблем у XIX ст. грунтувались переважно на алгебраїчних співвідношеннях та використанні лінійних, квадратичних, експоненціальних, поліноміальних, тригонометричних і комбінованих функціональних залежностей, то на початку XX ст. стали застосовувати диференціальні рівняння, зокрема для загального аналізу динаміки економічної системи. Розроблені наприкінці XIX ст. статистичні методи і підходи до аналізу економічних явищ, описані в працях Р. Гамільтона, К. Пірсона, Р. Фішера, Ф. Еджворта створили передумови для виникнення економетрії, що стала окремою науковою галуззю після заснування у 1930 р. з ініціативи I. Фішера, Р. Фріша, Я. Тімбергена, Й. Шумпетера, О. Андерсона та ін. економетричного товариства - «Міжнародного товариства для розвитку економічної теорії та іiї зв'язку зі статистикою i математикою». 
На початку 40-х років XX століття сформувався ще один самостійний науковий напрямок - математичне програмування, яке дало змогу використовувати новий науковий інструментарій для розв'язання фундаментальних економічних проблем (теорії ренти, ціноутворення, ефективності капіталовкладень, тощо). Це, перш за все, запропоновані у 1939 р. Л. Канторовичем методи розв'язання задач лінійного програмування за допомогою розв'язувальних множників, симплекс-метод розв'язання задачі ЛП Дж. Данціга, транспортна задача організації перевезень із мінімальними витратами Хічкока, метод потенціалів Л.В. Канторовича та М.К. Гавуріна.

3 середини 40-х років розвивається теорія ігор, яку вперше систематизовано виклали Дж.фон Нейман і О. Моргенштерн у 1944 р. у контексті аналізу економічної поведінки та прийняття рішень в умовах невизначеності та конфліктних ситуацій. Цим же періодом датується виникнення кібернетики, засновником якої став американський математик, професор Норберт Вінер, ідеї та методи якої, будучи застосовані до дослідження економічних систем, сформувалися в окрему науку - економічну кібернетику.

У 50 - 70 роках, у зв'язку із розвитком електроннообчислювальної техніки, відбувався процес удосконалення економіко-математичних методів і моделей та розширення сфери їх практичного застосування. На зміну статистичним та жорстко детермінованим моделям прийшли динамічні та стохастичні моделі, які враховують фактор випадковості та невизначеності (Р. Фріш, Я. Тінберген, С. Кузнець, К. Ерроу, Л.Клейн та ін.). Розвиваються проекційно-ітеративні та варіаційно-ітеративні методи, які дають змогу розв'язувати задачі великої розмірності (Н.Н. Боголюбов, Н.М. Крилов, М.Ф. Кравчук, А.Ю. Лучка), методи сіткового планування (метод критичного шляху СРМ, метод оцінки і аналізу програм PERT), що дозволяють мінімізувати тривалість проектів, виникає новий інструментарій економетричних досліджень у вигляді моделей одночасних рівнянь (Т.Кумпанс, Т.Хаавельмо, Г.Гейл та ін.), удосконалюються моделі економічного розподілу та оцінки ресурсів для планового періоду, зокрема оцінки капіталовкладень 3 позицій теорії двоїстості, розробляються оптимальні моделі перспективного планування (Л.В. Канторович, В.С. Немчинов, В.Л. Макаров, А.Б. Горстко).

Загалом на кінець XX ст. використання різноманітних математичних методів та підходів до розв'язання економічних задач на мікро- та макрорівнях сформувало певні наукові напрямки, які можна структурувати наступним чином: кореляційний аналіз, 
спектральний аналіз, дисперсійний аналіз, регресійний аналіз, кластерний аналіз, факторний аналіз, панельний аналіз стали основою економетрії.

Базу дослідження операцій склали аналітичні методи (теорія ймовірностей, теорія марковських процесів, теорія масового обслуговування, динаміка середніх), статистичні методи (послідовний аналіз, метод статистичних випробувань), математичне програмування (лінійне, нелінійне, динамічне, методи мережевого планування), теоретико-ігрові методи (теорія ігор, теорія статистичних рішень).

Основними напрямами розвитку економічної кібернетики стали теорія економічних систем i моделей (системний аналіз i моделювання економіки, економічне регулювання), теорія економічної інформації (теорія інформаційних потоків, економічна семіотика), теорія керуючих систем (планування, проектування i впровадження автоматизованих систем керування).

До математичної економіки увійшли моделі міжгалузевого балансу (статичні та динамічні), матричні моделі підприємств, лінійно-програмні моделі раціоналізації перевезень, теорії економічного росту, теорії виробничих функцій, аналіз попиту та пропозиції, регіональний та просторовий аналіз, глобальне моделювання і т.д.

До окремої групи можна віднести експертні методи економіки, a саме: математичні методи аналізу i планування економічних експериментів; імітаційне моделювання; ділові ігри; методи експертних оцінок (метод комісії, дельфійський метод, метод прогнозованого графа); методи оцінки ризиків; а також методи прогнозування.

3 початку XXI ст. по сьогоднішній день відбувається поглиблення і розширення процесів математизації і комп’ютеризації економічної науки, пов'язане із наростанням складності та абстрактності фундаментальних наукових знань, прискоренням глобальної економічної інтеграції, підвищенням ролі транснаціональних соціально-економічних, інформаційних i технологічних мереж, необхідності адаптації національних соціально-економічних систем до вимог світового ринку інноваційної продукції.

Актуальною залишається проблема керованості складних соціально-економічних систем та пошук важелів впливу, що переводять їх у бажаний стан. Процес розвитку таких систем з точки зору математики розглядають як динамічну модель, а оскільки при 
побудові динамічних систем досить часто виникає ефект запізнення - затримка в реакції системи на певний проміжок часу, то при вирішенні проблеми керованості застосовують, зокрема, лінійні та нелінійні диференціальні рівняння із запізненням, теорію яких започаткували В. Вольтерра, А.Д. Мишкіс, Н.Н. Боголюбов, Д.Я. Хусаїнов, В.І. Фодчук.

Інший спосіб аналізу поведінки систем полягає у використанні для їх опису замість диференційних рівнянь знань експертів, що формалізуються у вигляді нечітких множин. Основи нечіткої логіки були закладені у працях відомого американського математика Лотфі Заде, і на сьогоднішній день нечітка логіка застосовується, зокрема, при аналізі нових ринків, біржовій грі, побудові політичних рейтингів та прогнозів, виборі оптимальної цінової стратегії, оцінці рівня зрілості процесів захисту інформації та ін. Так, успішним прикладом застосування нечіткої логіки стало комплексне моделювання системи охорони здоров'я і соціального забезпечення Великої Британії (National Health Service), що вперше дозволило точно оцінити й оптимізувати витрати на соціальні нестатки. На вітчизняному ринку комерційних систем на основі нечіткої логіки до найбільш популярних пакетів відносяться CubiCalc 2.0 RTC, CubiQuick, RuleMaker, FuziCalc, що широко використовуються в області політичного й економічного аналізу.

На сьогоднішній день такі математичні інструменти, як нечіткі методи, нейронні мережі, генетичні алгоритми і т.п. все частіше застосовуються при аналізі поведінки соціально-економічних систем, оскільки, як показує практика, динаміка економічних процесів і явищ має нелінійний, часто непередбачуваний (хаотичний) характер. Однак при аналізі ринкової динаміки жоден з цих методів не може врахувати здатність ринку до самоорганізації. Вирішити цю проблему, до певної міри, дозволяє теорія фракталів, описана в працях Б. Мандельброта, Е. Петерса, В. Арнольда, П. Берже, І. Помо, Х. Стенлі, В. Чоу та ін. Така властивість фрактала, як здатність до самоорганізації, дозволяє розглядати його в якості математичного об'єкта, що найбільш точно відповідає системній природі соціальних та економічних процесів, які протікають в умовах нелінійної динаміки багатьох зовнішніх та внутрішніх факторів впливу. Одним із прикладів найбільш ефективного застосування теорії фракталів $\epsilon$ фрактальна модель фондового ринку.

Попри те, що математика глибоко проникла в усі сфери економіки і стала невід'ємним та дієвим інструментом пізнання економічних явищ та процесів, десятиліттями точиться дискусія 
навколо так званої проблеми надмірної математизації економіки. Зокрема, В.М. Тарасевич зазначає, що аналізуючи темпи і характер експансії математики в чисту неокласичну теорію, приходиш до думки, що гострота інтересу до отримання істинного знання за допомогою математичних методів обернено пропорційна гостроті вражень від складних економіко-математичних конструкцій, що мають мало спільного з реальністю [1, с. 91]. На цю проблему у свій час звертали увагу Г. Гегель, А. Пуанкаре, В. Гейзенберг, А.Н. Крилов, В.І. Вернадський, які вважали, що математика може бути формою відображення досліджуваного процесу, але не може відображати його змісту, а математичні методи слід застосовувати розумно, щоб не опинитись у штучно створеній знаковій системі, яка не дозволяє осягнути живий, реальний матеріал дійсності [2, с. 428].

Обгрунтуванню необхідності підтвердження своїх ідей фактами, врахування сутності економічних явищ при їх математичній обробці присвячені праці Р. Нельсона «Економіка як релігія» (2001), Т. Маєра «Істина проти точності в економічній науці» (1992), Д. Макклоскі «Риторика економіки» (1998), Пола Флейдерера «Хамелеони: зловживання теоретичними моделями у фінансах та економіці» (2014), Поля Ромена «Математизованість у теорії економічного росту» (2015). У статті лауреата Нобелівської премії Пола Кругмана «How Did Economists Get It So Wrong?» (2009) говориться не лише про невідповідність реаліям життя абстрактних моделей, що містять складний математичний апарат, a i про шкідливість деяких із них. Натомість інші відомі економісти, зокрема Джон X. Кохран, вважають, що проблема не у надмірі математики, a, радше, в тому, що «у нас іiї недостатньо».

Загалом можемо констатувати, що у XXI ст. започатковано принципово нову парадигму вивчення економічних процесів, i зокрема ринків, за якою порядок зароджується з хаосу, коливання лежать в основі організації, а випадковість відіграє конструктивну роль в еволюційних процесах. I поки теоретики сперечаються щодо доцільності математизації економіки, практики успішно використовують найновіші досягнення точних наук: теорію хаосу, нейронні мережі, нечіткі множини, фрактальну геометрію при аналізі поведінки соціально-економічних систем та розробці ефективних стратегій їхнього розвитку. 


\section{Список використаної літератури}

1. Тарасевич В.М. Проблематика істини у світовій економічній науці / В.М. Тарасевич // Економіка України. - 2018. - №10 (683). - C. 88- 99.

2. Шигун М.М. Застосування математичних методів в економіці: специфіка, проблеми, перспективи / М.Шигун // Вісник ЖДТУ. Серія: Економічні науки. - 2007. - №1 (39). — С. 425 - 433.

Гриценко АA., чл.-кор. НАН України, д.е.н., професор, Інститут економіки та прогнозування НАН України

\section{ГЛОБАЛЬНА НЕСТАБІЛЬНІСТЬ СОЦАЛЬНО- ЕКОНОМІЧНОЇ ДИНАМІКИ ЯК ОБ'ЄКТИВНЕ ПІДГРУНТЯ ПАРАДИГМАЛЬНИХ ЗРУШЕНЬ В ЕКОНОМІЧНІЙ НАУЦІ}

Глобальна нестабільність соціально-економічного розвитку свідчить про неспроможність сучасної економічної науки дати відповідь на історичні виклики і озброїти суспільство інструментами і механізмами забезпечення стабільного розвитку. Про це свідчать дії урядів і центральних банків розвинених країн, які в умовах кризи застосовували заходи, які суперечать традиційним теоретичним уявленням. Зв'язки макроекономічних параметрів також відрізняються від традиційних. Так, в ході реалізації політики «кількісного пом'якшення» в економіку США було влито більше 4 трлн. дол., але це не привело до відповідного зростання інфляції. Натомість суттєво зросли фондові індекси. Наприклад, індексу S\&P500 з 2009 р. по 2018 p. зріс на $283 \%$, в той час як інфляція за цей період збільшилася лише на $20 \%[1,2]$.

На зміни у зв'язках економічних параметрів впливають різноманітні чинники, але їх узагальнена дія відбивається в посиленні глобальної нестабільності. Для того, щоб протидіяти цій тенденції необхідно знати субстанційну основу цього процесу. А іiі потрібно шукати в основному змісті сучасних трансформацій. Основоположне значення в сучасних трансформаціях відіграє перехід від 
індустріально-ринкової до інформаційно-мережевої економіки. Ці дві системи господарювання мають у своїй основі принципово відмінні закони функціонування. У індустріально-ринковій економіці головний продукт приймає форму товару і обмінюється на ринку за законом вартості. На відміну від цього в інформаційно-мережевій економіці головним продуктом є інформація, яка може бути одночасно власністю всіх і кожного, і відносини з природу виробництва, розподілу, обміну і споживання інформації не можуть мати в своїй основі вартісний характер навіть в тому випадку, коли зберігається вартісна форма, як це відбувається у перехідний період від одного типу господарювання до іншого.

Принциповий характер змін можна проілюструвати на прикладі попиту на ординарні та мережеві блага. Криві попиту на ординарні блага і мережеві блага суттєво відрізняються. Перша є спадаючою, а друга - зростаючою. Мережеве благо тим корисніше, чим більше його споживачів. Відповідно більшою може бути і його ціна. Наприклад, мобільний телефон як змішане благо в якості ординарного блага втрачає корисність із збільшенням його кількості у споживача, але в якості мережевого блага його корисність вимірюється інакше і зростає разом із кількістю споживачів. Крива попиту на таке ординарномережеве благо буде складатися із поєднання спадаючої і зростаючої кривих попиту. Нинішні прогнозні моделі не налаштовані на такі залежності, тому з часом прогнози стануть все більше розходитися 3 реальністю, що буде також фактором посилення нестабільності.

Основоположне значення вартості в індустріально-ринковій економіці при переході до інформаційно-мережевої економіки втрачається. Відбувається деструкція вартості. Втрачається еквівалентність економічних відносин, і на зміну їм приходить реципрокність. Вартісні відносини ідеалізуються і переносяться у віртуальний простір. Внаслідок цього світ стає гібридним. Розвиток цифрової економіки підводить під гібридний світ технологічну базу. Віртуальне виступає як таке ідеальне, яке винесено за межі людської голови і представлене як реальне [3, с.11]. Разом 3 цим формується рефлексійність відносин: віртуальне як реальне існує лише у відношенні до ідеального відображення, існуючого в голові людини. А ідеальне відображення в голові людини існує лише як образ віртуального. Ця рефлективність складає суттєву характеристику гібридної економічної дійсності.

Разом 3 деструкцією вартості змінюються i механізми ціноутворення. Економічні категорії поступово наповнюються новим змістом, що також є фактором нестабільності. Соціально-економічна 
динаміка змінюються під впливом дестабілізаційного впливу нових механізмів емісії грошей, інноваційних фінансових технологій, появи криптовалют тощо. Трансформується і глобалізується соціальноекономічний простір. Історично спочатку виникає господарський простір, що являв собою фізичний простір господарської діяльності людини (території, матеріальні ресурси, предмети, засоби праці і т. ін.), спрямованої на відтворення умов іiі власної життєдіяльності. Економічний і соціальний простори тут знаходяться у синкретичній єдності, а час тече циклічно.

Соціально-економічний простір у власному визначенні формується разом 3 індустріально-ринковою системою господарювання. Субстанцією цього простору стає вартість в усіх своїх предметних, соціальних та ідеальних формах прояву. Весь оточуючий світ, створений людиною, виступає як соціальноекономічний простір іiі діяльності. Економічна і соціальна складові цього простору вже відокремлені і знаходяться у суперечливій взаємодії, а час протікає лінійно, що асоціюється з прогресом.

3 розвитком сфери послуг та інформаційних технологій втрачається форма уречевлення праці як основи створення вартості і виникає можливість миттєвої зміни просторової локалізації цінності. Вартість із суспільно-необхідних (середніх) витрат праці на виготовлення товару перетворюється у форму просторової локалізації суспільно-необхідних витрат часу на створення блага, а гроші стають представником такої вартості в обігу. Внаслідок цього виникає ситуація, коли величезні грошові статки можуть миттєво змінювати свою локалізацію у просторі (переміщуватися, наприклад із Києва до Лондона, не перебуваючи в будь-яких проміжних точках, подібно тому як у фізиці змінює свою просторову локалізацію електрон). В цьому перетворенні суспільний час стає локалізований простором, а останній представляє собою суспільний час. Соціально-економічний простірчас стає єдиною реальністю, так само як це відбувається у фізиці. Разом з розвитком інформаційно-мережевих характеристик економіки соціально-економічний простір також набуває мережевого характеру. За своєю формою він стає квантово-мережевим простором.

Така ситуація приводить до посилення різношвидкісного руху базових елементів соціально-економічної системи (гроші і капітали можуть змінювати свою просторову локалізацію миттєво, робоча сила потребує на зміну просторової локалізації часу і додаткових витрат; товари і послуги мають свою швидкість і особливості просторової локалізації). Різношвидкісність цих процесів (переливів капіталів, трудової міграції, торгівельних потоків) і диспропорції, які виникають 
на цій базі є конкретними проявами основної суперечності сучасної епохи: між глобалізацією, яка знаходить адекватні собі форми через інформаційно-мережеві та фінансові технології, і локалізацією матеріальних і трудових ресурсів, які не можуть рухатися у просторі зі швидкістю інформації та грошей.

Така ситуація створює принципову можливість миттєвого виникнення глибоких криз i перетворення нестабільності у фундаментальну характеристику соціально-економічної динаміки. Це також наглядно демонструє необхідність парадигмальних змін в економічній теорії. Вони повинні починатися 3 переосмислення базових економічних категорій: вартості та форм іiї прояву, власності, форм і видів соціально-економічної діяльності та іiі локалізації у просторі, закономірностей розподілу результатів виробництва, багатства.

\section{Список використаних джерел}

1. $\quad$ S \& P 500 [ Електронний ресурс]. - Режим доступу: https://finance.yahoo.com/quote/\%5EGSPC/history?p=\% EGSPC

2. Consumer Price Index [ Електронний ресурс]. - Режим доступу: https://fred.stlouisfed.org

3. Гриценко А.А. Цифровий розвиток: структура, капіталізація та соціалізація // Економічна теорія. - 2018. - № 4. - С.5-20.

Дзюба П. В., д.е.н., доцент, Київський національний університет імені Тараса Шевченка

\section{СУЧАСНА ТЕОРІЯ МІЖНАРОДНОГО ПОРТФЕЛЬНОГО ІНВЕСТУВАННЯ: БІПАРАДИГМАЛЬНІ ОСНОВИ ТА ПЕРСПЕКТИВИ РОЗВИТКУ}

Сучасна теорія міжнародного портфельного інвестування $\epsilon$ комплексним, складним і надзвичайно багатогранним знанням, яке пройшло складний шлях еволюційного розвитку, наукових революцій, продовжує трансформуватися сьогодні. 3 одного боку, це знання $є$ високо математизованим - для прийняття інвестиційний рішень будуються складні економетричні моделі, здійснюються 
багатоваріантні ймовірнісні оцінки й прогнози, розробляються комплексні портфельні стратегії. 3 іншого боку, прийняття інвестиційних рішень часто базується на досвіді та інтуїції самих інвесторів, є суб'єктивним за своїм характером, не передбачає конкретних кількісних оцінок, але поряд 3 цим часто $є$ не менш ефективним.

На перший погляд, наявне теоретичне знання важко систематизувати та узагальнити, зважаючи на його розмаїття, комплексний характер та багаторівневу структуру. Однак, детальний аналіз та комплексне дослідження різноманітних теорій, концепцій та підходів, що використовуються для пояснення рішень міжнародних портфельних інвесторів, дає змогу зробити висновок, що сучасна теорія міжнародного портфельного інвестування розвивається на біпарадигмальній основі. Поряд із модерною та значно поширенішою портфельною парадигмою для пояснення рішень міжнародних інвесторів застосовують положення традиційної вартісної парадигми. Важливою відмінністю між ними $є$ те, що результати портфельної парадигми об'єктивні й точніші: вони базуються на розрахунках. Оцінки ж вартісної парадигми - суб'єктивні. Однак у портфельній парадигмі суб'єктивними є вхідні дані, що негативно впливає на начебто об'єктивний результат, а тому спостерігається парадокс: результати суб' єктивної вартісної парадигми часто викликають менше сумнівів, ніж висновки об'єктивної портфельної парадигми. Остання передбачає розгляд портфеля як нової інвестиційної якості. Вартісна ж парадигма робить акцент на окремих цінних паперах (табл. 1).

Таблиия 1

\section{Порівняння портфельної та вартісної парадигм міжнародного портфельного інвестування}

\begin{tabular}{|l|c|c|}
\hline \multirow{2}{*}{ КРИТЕРІЙ } & \multicolumn{2}{|c|}{ ПАРАДИГМА } \\
\cline { 2 - 3 } & Портфельна & Вартісна \\
\hline Вхідні дані & Суб'єктивні & Об’єктивні \\
\hline Вихідний результат & Об'єктивний & Суб'єктивний \\
\hline Об'єкт розгляду & Портфель & Окремі папери \\
\hline Диверсифікація & Так & Ні (так) \\
\hline Ризик & Так & Ні (так) \\
\hline Фундаментальні показники & Ні & Так \\
\hline Тип інвестора & Інституційні & Будь-які \\
\hline
\end{tabular}


Обидві парадигми відповідають загальноприйнятим ідентифікаторам парадигми за Т. Куном [1, с. 11, 37-38]. Обидві є загальновизнаними, обидві домінують упродовж тривалого часу, обидві являють собою модель постановки наукових проблем, обидві дають модель вирішення поставлених наукових проблем.

Виникнення портфельної парадигми датують 1952 роком, коли вийшла друком фундаментальна стаття Г. Марковіца [6]. Попри свою цілісність та епістемологічну самодостатність вона передбачає наявність п’яти концепцій: концепції ефективного інвестиційного портфеля, концепції диверсифікації інвестиційного портфеля, концепції міжнародної диверсифікації інвестиційного портфеля, концепції оптимізації інвестиційного портфеля та концепції оцінювання дохідностей. Ключовими гносеологічними ознаками портфельної парадигми міжнародного інвестування є такі. По-перше, - нормальний характер розподілу дохідностей. По-друге, квадратичний вигляд функції корисності. По-третє, - раціональний характер поведінки інвесторів. По-четверте, - унікальність кожного інвестиційного портфеля, котрий розглядається як нова інвестиційна якість. По-п'яте,такі портфелі формуються на основі диверсифікації, яка в теорії портфеля стає пріоритетною порівняно з максимізацією дохідності від інвестицій, що виключала пріоритетність диверсифікації. За теорією портфеля, диверсифікація передбачає аналіз кореляцій між дохідностями активів у складі портфеля - вони мають бути мінімальними та позитивними.

Важливе місце в розвитку портфельної парадигми посідає урахування лише ризику збитків, а не сукупного ризику, що зумовило трансформацію парадигми від теорії портфеля до постсучасної теорії портфеля, формальна ідентифікація якої відбулася у 1993 році [7]. Сутнісна основа постсучасної теорії портфеля полягає в тім, що вона поряд із першим та другим моментами розподілу випадкових величин розглядає також третій момент - асиметрію розподілу, а сама оптимізація стає тримоментною. Більшість емпіричних досліджень свідчать, що оптимізація за постсучасною теорію портфеля дає кращі результати порівняно з оптимізацією за традиційними показниками. Оптимізація також може здійснюватися на основі четвертого та вищих порядків розподілу випадкових величин. Саме в напрямі оптимізації за третім та особливо четвертим i вищими моментами розподілу дохідностей портфельна парадигма міжнародного інвестування розвиватиметься в найближчі 20-25 років.

Вартісна парадигма міжнародного інвестування виникла у 1934 році на основі запропонованої тоді Б. Гремом і Д. Доддом системи 
оцінювання цінних паперів [2]. У своїй еволюції вона пройшла три етапи. Від 1934 року до початку 1950-х років - етап зародження та активного розвитку. Другий етап - від першої половини 1950-х років до першої половини 1990-х років - етап інертного розвитку, коли починає домінувати нова на той час портфельна парадигма. Тоді у парадигмі вартісного інвестування не відбувається суттєвих змін, іiі релевантність значною мірою обстоюється практикою інвестиційного менеджменту. Третій етап - від 1993 року і дотепер - відновлення позицій вартісної парадигми та активізація іiі розвитку. Остання зумовлена двома головними чинниками: важливі прориви в самій парадигмі; критика та переосмислення окремих концептів портфельної парадигми. Застосування положень вартісної парадигми передбачає пошук неправильно оцінених цінних паперів. Вона ігнорує короткотермінові впливи, натомість орієнтуючись на довготермінові інвестиційні стратегії. Саме у довготерміновій перспективі ціни активів тяжітимуть до їхньої реальної вартості. Окрім моделі ФамиФренча поширеними методами фундаментального аналізу $\epsilon$ дисконтування майбутніх грошових потоків, а також система оцінювання цінних паперів Грема й Додда. Подальший розвиток вартісної парадигми міжнародного інвестування відбуватиметься на основі вдосконалення моделі Фами-Френча, в якій зростатиме кількість факторів, змінюватиметься їхній склад та збільшуватиметься питома вага міжнародних чинників формування очікуваних дохідностей.

Особливе місце в сучасній теорії міжнародного портфельного інвестування посідає бігевіоризм. У гносеологічному сенсі він не відноситься ані до портфельної, ані до вартісної парадигм, натомість впливає на будь-яких інвесторів, коригує інвестиційні рішення, що передбачені обома парадигмами 3 урахуванням ірраціональної поведінки індивідів. Появі поведінкової теорії портфеля передували поведінкові теорії більш загального спрямування, такі як теорія перспектив [4] і так звана теорія SP/A [5]. Поведінкова теорія портфельного вибору була сформульована не так давно - у 2000 році. Вона базується на двох зазначених теоріях та інкорпорує ідею множинного (подвійного) ментального обліку [8]. Портфель розглядається не лише як цілісність, а як поєднання двох умовно окремих частин (для високого рівня прагнення інвестора та для низького), управління кожною з яких відбувається окремо та на основі різних інвестиційних цілей.

Найбільш значущою серед сучасних теорій $є$ теорія поведінкового портфельного менеджменту Т. Говарда, що була 
розроблена в 2014 році [3]. За цією теорією основним чинником зміни ціни на ринку є емоції натовпів, які нездатні або не бажають відпускати гальма своїх емоцій. Поведінкові інвестори, натомість, повинні керуватися фундаментальними характеристиками цінних паперів та можуть досягти успіху, інвестуючи в протилежному від натовпів напрямі. Портфельний менеджмент має носити довготерміновий характер.

Поведінкова теорія Говарда базується на трьох принципах. Поперше, на ринку є дві групи учасників: емоційні натовпи та поведінкові інвестори. Ціни на ринку визначаються саме емоційними натовпами, а тому не відображають внутрішню вартість активів; відхилення цін $є$ радше правилом, ніж винятком. При цьому події, котрі дають стимул діям натовпів, можуть мати короткотерміновий характер, а емоції, що виникатимуть унаслідок цього, - довготерміновий. Інвестиційні рішення поведінкових інвесторів $є$ ментально важкими, оскільки вони передбачають займання позицій, протилежних тим, що займають емоційні натовпи, а сам процес поведінкового інвестування передбачає використання довготермінових портфельних стратегій.

Перспективи розвитку теорії міжнародного портфельного інвестування оцінюємо як такі, що відповідають домінантному нині зрушенню науки в міждисциплінарному напрямку, в рамках якого домінуватиме розвиток поведінкових теорій та підходів, які дедалі більше та органічніше поєднуватимуться 3 положеннями ідентифікованих парадигм, а у перспективі - цілком можливим є їх виокремлення та набуття самодостатнього гносеологічного статусу.

\section{Список використаних джерел}

1. Кун Т. Структура научных революций. С вводной статьёй и дополнениями 1969 г. / Т. Кун; [пер. с англ. И. З. Налетова]. М. : Прогресс, 1977. - 300 с.

2. Graham B. Security Analysis / Benjamin Graham, David L. Dodd. - New York, London : Whittlesey House, McGraw-Hill Book Company, Inc., 1934.-725 p.

3. Howard C. T. Behavioral Portfolio Management: How Successful Investors Master Their Emotions and Build Superior Portfolios / C. Thomas Howard. - Harriman House Ltd., 2014. - 324 p.

4. Kahneman D. Prospect Theory: An Analysis of Decision under Risk / Daniel Kahneman, Amos Tversky // Econometrica. - 1979. - Vol. 47, № 2. - P. 263-292. 
5. Lopes L. L. Between Hope and Fear: The Psychology of Risk / Lola L. Lopes // Advances in Experimental Social Psychology. - 1987. Vol. 20, № 2. - P. 255-295.

6. Markowitz H. M. Portfolio Selection / Harry Markowitz // The Journal of Finance. - 1952. - Vol. 7, № 1. - P. 77-91.

7. Rom B. A. Post-Modern Portfolio Theory Comes of Age / Brian M. Rom, Kathleen W. Ferguson // The Journal of Investing. - 1993. Vol. 2, № 4. - P. 27-33.

8. Shefrin H. Behavioral Portfolio Theory / Hersh Shefrin, Meir Statman // The Journal of Financial and Quantitative Analysis. - 2000. - Vol. 35, № 2. - P. 127-151.

Смець В.В., к.е.н., експерт Інституту стратегічних досліджень «Нова Україна»

\section{ЕВОЛЮЦІЯ МЕТОДОЛГІЇ ДОСЛІДЖЕННЯ ЕКОНОМІЧНОГО ПОНЯТТЯ «НАГРОМАДЖЕННЯ КАПІТАЛУ}

Вивчаючи еволюцію теоретичних підходів до визначення сутності нагромадження капіталу за критерієм його функціональної приналежності виокремлюємо п'ять етапів, що пройшли теоретичні вчення про капітал у процесі свого розвитку: 1. Індивідуальносуспільної значущості нагромадження капіталу (період до н.е. - V ст.н.е.); 2. Нагромадження грошових капіталів (з VI ст. до XVI ст.); 3. Промислово виробничої спрямованості капіталу (з середини XVII ст. до кінця XVIII ст.); 4. Інвестиційної-орієнтованості капіталу (з середини XIX ст. до 70-х років XX ст.) та 5. Глобально-інтенсивної спрямованості капіталу (з середини XIX ст. до 70-х років XX ст.). Дослідження еволюції теоретичних поглядів, крім іншого, виявляє, що у продовж усього періоду дослідження феномену нагромадження капіталу, вчені звертали увагу на те, що нагромадження не є сталим та безперервним, а існують фактори, які спричиняють зворотні процеси щодо нагромадження капіталу, його фактичну деструкцію.

Перший eman, який тривав 3 точно не визначеного часу до нашої ери до V ст.н.е., характеризується розвитком переважно натурального виробництва приватними господарствами. Основою виробництва являється сільське господарство та в незначній мірі ремісництво. Функцію грошей виконують дорогоцінні метали (золото, срібло, мідь). 
Кредитні відносини знаходяться у зародковому стані. Нагромадження капіталу відбувається у формі розвитку приватних (індивідуальних) господарств, а також накопичення цінних металів для подальшого їх використання щодо певних суспільних потреб.

На цьому ранньому етапі розвитку економічної думки інтереси дослідників [1] в основному були спрямовані на визначення індивідуально-суспільної значущості капіталу, вагомості нагромадження капіталу як фактору сталого розвитку. На цих проблемах, передусім, сконцентровані дослідження давньогрецьких філософів-економістів.

Упродовж другого emany (V-XVI ст.н.е.) проявляється нагромадження грошового капіталу у вигляді розростання активності банківських установ, основною функцією діяльності яких стало примноження капіталу. Ці події відбувалися на фоні зрілого феодалізму за формаційним підходом, який характеризувався розвитком переважно натурального господарства на великих феодальних територіях, які уособлювали багатство. Основою економіки було натуральне та промислове виробництво в рамках цехової ремісничої системи. Базовим елементом функціонування феодальної системи були станові привілеї, які закріплювали за феодалами, подекуди надаючи їм безмежну владу на підконтрольних територіях. В цей же період набуває нормативного врегулювання інститут банкротства, одними 3 перших починають регулювати ці відносини англійські статути 1283 i 1285 p.p., що може розглядатися як унормування інструментарію протидії проявам деструктивних економічних факторів на нагромадження грошового капіталу.

У продовж третього етаny - 3 середини XVII ст. до кінця XVIII ст. теоретичні погляди щодо розкриття економічної сутності нагромадження капіталу фокусувались [2;3;4;5;6;7], в основному на нагромадженні у вигляді промислового капіталу, основною функцією якого було забезпечення розширеного відтворення. Тому цей етап еволюції теоретичних підходів до розкриття сутності «нагромадження капіталу» ми називаємо періодом промислово-виробничого нагромадження капіталу. При цьому, в той час відбувалось зосередження праць вчених-сучасників на аспектах, які стосувалися головним чином значення кількісного нарощення виробничих активів, хоча і в новій їх якості (як результат промислового перевороту). Натомість питання, пов'язані з напрямками підвищення ефективності використання таких активів, були поза увагою.

У продовж четвертого періоду, який ми називаємо інвестиційноорієнтованим (з середини XIX ст. до 70-х років XX ст.), домінуючою 
формою капіталу став інвестиційний капітал, основна функція якого була пов'язана 3 універсіалізацією його використання, яка стала можливою завдяки появі критеріїв та інструментів оцінки ефективності його використання і в цілому розвитку наукової теорії, пов'язаної 3 інвестуванням [8;9;10]. Разом із тим, прийдешні перетворення в економічних процесах світу сприяли черговим змінам у поглядах вчених щодо ролі нагромадження капіталу.

Відзначимо, що період глобально-інтенсивного спрямування капimaлiв (n'ятий eman), який розпочався у 70-х роках минулого століття та триває донині, на нашу думку, у найближчі роки буде формуватися за рахунок досліджень, завданням яких буде пошук оптимальних шляхів розвитку глобальної економіки в умовах значного ускладнення (а відповідно і підвищення вартості) добування корисних копалин (нафта, мідь), а в окремих випадках і їх гострого дефіциту (олово, уранові руди) на фоні зародкового стану розвитку перекриваючих технологій. У зв'язку з цим вільні капітали будуть шукати ніші для розвитку суперінтенсивних технологій (у сенсі обмеженості ресурсів), а також залучення до цього процесу найталановитіших, висококваліфікованих робітників.

На нашу думку процес нагромадження капіталу може трактуватися як у широкому, так і у вузькому сенсі. У широкому сенсі «нагромадження капіталу» - це процес облаштування життєвого простору людини у його матеріальному аспекті, саме капітал в усі часи був основною рушійною силою цілеспрямованої діяльності людей пов'язаною з економічним та соціальним розвитком, його якісними та кількісними характеристиками. Не випадково еволюція поглядів на процеси нагромадження капіталу на кожному з історичних етапів була тісно пов'язана із загальною логікою змін у розвитку суспільства i відповідного зі змінами способу життя. У вузькому сенсі «нагромадження капіталу» зводиться до забезпечення процесу перманентності розширеного відтворення у сенсі нарощення основної діяльності господарюючого суб'єкта i переливання частини сформованої доданої вартості на цілі пов'язані з розширенням (якісним та кількісним) фондів, які є основою ведення такої діяльності.

\section{Список використаних джерел:}

1. Аристотель. Сочинения: В 4-х томах / за заг. ред. А. И. Доватура. Москва: Мысль, 1983. 830 с. 
2. Бем-Баверк, Ойген фон. Капитал и процент 1884-1889. Избранные труды о ценности, проценте и капитале. М.: Эксмо, 2009. C. 247-812. 912 c.

3. Кене Ф. Избранные экономические произведения. М.: Соцэкгиз, 1960. $551 \mathrm{c}$

4. Кларк Дж. Б. Распределение богатства. М.: Гелиос АРВ, 2000. 367 c.

5. Людвиг фон Мизес. Теория денег и кредита. Челябинск: Социум, 2012. $808 \mathrm{c}$.

6. Маршал А. Принципы экономической науки: в 3 т. М.: Прогресс, 1993. Т. 1.415 с.

7. Кейнс Дж. М. Общая теория занятости, процента и денег. М.: Эксмо, 2007. 960 с.

8. Fisher, I. The theory of interest, as determined by impatience to spend income and opportunity to invest it. New York: Macmillan, 1930.

9. Fama, E. F., French, K. R. The Capital Asset Pricing Model: Theory and Evidence. Journal of Economic Perspectives. 2004. Vol. 18, №3. P. 25-46.

10. Krugman, P. Crises: the price of globalization? [El. Resource]. Federal Reserve Bank of Kansas City. Economic Policy Symposium. URL: https://www.kansascityfed.org/PUBLICAT/SYMPOS/2000/S00kr ug.pd 
Зайцев Ю.К.,

доктор економічних наук, професор, Київський національний економічний університет імені Вадима Гетьмана

\title{
ФІЛОСОФІЯ РОЗВИТКУ ГЛОБАЛЬНОЇ ЕКОНОМІКИ ТА СУСПІЛЬСТВА В УМОВАХ ЧЕТВЕРТОЇ ПРОМИСЛОВОЇ РЕВОЛЮЦІї
}

\author{
"Ми створили циивілізаціюю "зіркових війн” - \\ з емоціями кам'яного віку, суспільними \\ інститутами Середньовіччя та технологіями \\ гідними богів" - Уілсон Е. (2014) “Хозяева \\ Земли. Сочиильное завоевание планеты \\ человечеством»
}

“Найбільшою революцією у нашому поколінні, вважає Уільям Джеймс, стало відкриття того, що людські істоти шляхом зміни внутрішнього стану свого розуму можуть змінювати зовнішні аспекти свого життя" [3, с. 3.]. Цілком погоджуючись із такою думкою У. Джеймса, зазначимо, що найпотужніша технологічна революція в історії людства та сучасного суспільства, створюючи передумови задоволення усієї сукупності нагальних потреб суб'єктів економічного та соціального життя на планеті, водночас формує принципово нові можливості та інструменти впливу на процеси управління самим життям цих “людських істот”, їхньою психікою, бажаннями, емоціями тощо, i це $\epsilon$ надзвичайно актуальним викликом i загрозою для існування, як окремої людини, так i цілого суспільства в інституціональному полі ціннісних орієнтирів нашої цивілізації.

За цих умов формування та використання нової, сучасної техноекономічної парадигми, суть і функції якої з достатньою глибиною розкрили у своїх працях Клаус Шваб, Ніколас Дєвіс, Ерік С. Рейнерт та інші сучасні дослідники, ${ }^{1}$ стає явно недостатньо для розуміння

\footnotetext{
Шваб, Клаус. Четвертая промышленная революция : перевод с английского / Клаус Шваб. - Москва : Издательство «Э», 2018. - 208 с.; Шваб, Клаус. Технологии Четвертой промышленной революции : [перевод с английского] / Клаус Шваб, Николас Дэвис. - Москва : Эксмо, 2018. - 320 с.; Блуммарт Т. Четвертая промышленная революция и бизнес: Как конкурировать и развиваться в эпоху сингулярности / Тью Блуммарт, Стефан ван ден Брук при участии Эрика Колтофа; Пер. с англ. - М.: Альпина Паблишер, 2019. - 204 с.; Рейнерт Эрик С. Спонтанный хаос. Экономика эпохи рецессии / Эрик С. Рейнерт; [пер. с норв. А.В. Наумовой]. - М.: Политическая энциклопедия, 2017. - 190 с.; Дрекслер, Э. Всеобщее благоденствие. Как нанотехнологическая революция изменит цивилизацию [Текст] / пер. с англ. Ю.
} 
нагальних проблем і шляхів подальшого розвитку глобалізованого суспільства у довгостроковій перспективі.

Адже, по-перше, глобальна економіка в умовах революції 4.0 це не тільки концентрація можливостей людства на основі об'єднання зусиль, нової якості взаємодії національних економік та суспільств, формування філософії та реальних засад плюралістичної економіки ${ }^{1}$, але й нова філософія ціннісних орієнтирів, методів i форм економічного розвитку, ключовий, винятковий чинник зміни парадигми світосприйняття вченими, політиками, представниками владних структур. Вона вимагає кардинальних змін від суспільства, окремих соціальних груп i народів планети поза якими стає неможливим цивілізаційній резонанс, тобто системна рівновага між потребами та можливостями подальшого існування людства як певної цілісної інституціоналізованої соціальної та соціалізованої форми життя.

По-друге, взаємопов'язаний у часі та просторі процес розгортання революції 4.0 та глобалізованої економіки ускладнює не тільки суб'єктивне сприйняття глибини змін, що відбуваються на планеті, але й глибини тих потенційних можливостей, реальних викликів і суперечностей, які супроводжують ці зміни, породжуючи мегазагрози щодо збереження засадничих цінностей існуючої людської цивілізації через хибну уяву щодо гранично можливих етичних і видових меж трансформації цих цінностей, навіть в умовах безмежних технологічних ресурсів нанотехнологічних революцій,

Каптуревского; под науч. ред. С. Лурье. - М.: Изд-во Института Гайдара, 2014. - 504 с.; Форд, М. Роботы наступают: Развитие технологий и будущее без работы / Мартин Форд; Пер. с англ. - М.: Альпина нон - фикшн, 2016. - 430 с.; Что мы думаем о машинах, которые думают: Ведущие ученые об искусственном интеллекте / Джон Брокман; Пер. с англ. М.: Альпина нон-фикшн, 2017. - 549 с.

Плюралістична економіка (сформульовано нами - Ю.3.) 1) результат i форма об’єктивного процесу еволюції економічної системи у ході якого виникають, функціонують, співіснують і розвиваються різні інституціонально - правові моделі національних економік, навіть в інституціональному полі єдиної глобалізованої економічної системи; 2) економіки, моделі економічної політики, фундаментальну теоретичну основу яких складають парадигмальні підходи закладені на засадах різного теоретико-методологічного бачення різними вченими та політиками шляхів розв'язання однотипних проблем і завдань подальшого економічного розвитку. Різні наукові школи, різні суб'єктивні підходи до аналізу шляхів розв'язання реально існуючих проблем, суперечностей, задоволення потреб, інтересів суб'єктів економічного життя, викликають не лише плюралізм думок, концептуальних поглядів і теоретичних моделей розвитку, але й плюралізм підходів до формування практичної економічної політики забезпечення такого розвитку (кейнсіанство, неолібералізм, ордолібералізм, неоінституціоналізм, постнеолібералізм, сучасна політична економія тощо). 
економічної, політичної, духовної, етичної свободи, які ці революції породжують.

По-третє, "Сучасна теорія, - на думку Е. Рейнерта, з якою мабуть слід погодитись, - зазнає складнощів стосовно урахування якісних змін економіки, які в майбутньому стануть основою кількісних змін” [6, с. 55]. До того ж, вважає вчений, “в епоху зміни парадигми суспільство приходить у стан розгубленості. Подібна ситуація актуальна й для сучасної науки: у нас є значна кількість досліджень і висновків, i деякі 3 них спростовують одне одного". Водночас, зазначає цитований учений, “комбінація різних парадигм може привести до того, що ми почнемо вибирати керуючись власними інтересами - національними, або ще якимись. Якщо нам буде вигідно, ми скажемо, що земля кругла, а якщо невгідно - що вона пласка” [6, с. 55.]. Отже, кардинальні якісні зміни, що відбуваються у технологічному способі виробництва та в організаційно-економічній архітектоніці сучасного світу, економічний, соціальний, цивілізаційний розвиток на засадах перевантаження ресурсно - екологічних можливостей планети, індивідуалізації та атомізації інтелектуальної праці ${ }^{1}$, бурхливої роботизації усього циклу суспільного відтворення створюють передумови для нового філософського і парадигмального осмислення перспектив і можливих варіантів подальшого існування людини, людства, суспільства.

Лише нещодавно економічна наука, на засадах міждисциплінароного підходу, сформулювала принципи та суть людиноцентричної парадигми економічного та суспільного розвитку, вихідними принципами якої стало розуміння того, що, по-перше, “пружина историчного розвитку - у методах гармонічного узгодження активності вільно діючих гуманітарних істот»; по-друге, “нова філософія історії, виступаючи універсально цивілізаційною позаетнічною, позакласовою ідеологією самостановлення гуманітарності, не має історичних рамок"; по-третє, “цінність життя у втіленні в ньому фундаментальних соціальних констант; гуманітарних абсолютів. Розчленування Істини та Добра породжує інструменталізм”; по-четверте, “вісь життя - в гідному просуванні до матеріальної та духовної розкутості, повноті самореалізації через соціальний та екзистенціальний прогрес, сходження до гуманітарно високого" [2, с. $27 ; 40 ; 41]$.

Як вважає А. П. Назаретян, «те, що з розвитком технологій зростає потенційний ефект індивідуальних дій i тим самим спадає внутрішня стійкість суспільства (для забезпечення якої потрібно усе більше культурних самообмежень), логічний наслідок моделі техно - гуманітарного балансу” [4, с. 170]. 
Нажаль, наведені вище філософські принципи розуміння суті людиноцентричної парадигми щодо орієнтації розвитку сучасної економічної та соціальної системи, сформульовані всесвітньо відомим філософом В. В. Ільїним, не знімають суперечливої природи самої людини, яку цитований вище вчений характеризує таким чином: "парадоксальність людини у двоякості: вона конструюючий світ суб 'єкт та існуючий у світі об'єкт” [2, с. 35]. За цих обставин, вважаємо доцільною актуаліалізацію дослідження проблеми діалектики взаємозв'язку вже добре відомої людиноцентричної парадигми та парадигми трансгуманітарної. Сутнісні характеристики останньої безпосередньо пов'язані із специфічними поглядами значної групи вчених, політиків, бізнесменів на природу, можливості та функції людини у технологічно об'єднаному глобалізованому суспільстві. Зокрема, представники даного напрямку, як зазначають дослідники проблеми, “відмовляються від будь-яких догматичних трактувань (насамперед, релігійних) людського існування; вони розуміють розвиток наукового знання як передумову технологічного та біологічного вдосконалення людини; сприймають людського індивіда не як кінцевий продукт еволюції, а як проміжну стадію на шляху від біологічної особини до згустку інформаційно кібернетичних полів та вищого розуму". "По суті, трансгуманізм, на думку цитованого автора, - прагнення подолати обмеженість людини іiі фізіологічними характеристиками, сприймання індивіда як потенційно необмеженої у своєму розвитку сутності" [1, с. 96]. Водночас, інші, критично налаштовані, дослідники сутності трансгуманітарної парадигми економічного та соціального розвитку глобалізованого суспільства в умовах революції 4.0 висловлюються більш відверто, спираючись на думку експертів. Вони стверджують, що “саме реалізація євгенічної ідеї - створення “надлюдини” шляхом "розширення" нинішньої людини — i $є$ головною метою усієї технологічної діяльності, у той час, як решта $є$ лише “операцією прикриття" [5, с. 185].

За нашим переконанням, саме факт двоякості сутності людини стає основою цілої низки ризиків, пов'язаних із розвитком нанотехнологій у процесі четвертої промислової революції. Адже результати ï спрощують переходи людини та суспільства із однієї реальності до іншої - двоякість функціональної сутності людини може перетворити iї на об'єкт за допомогою новітніх технологій i новітніх ціннісних орієнтирів лідерів “якісно нової хвилі прогресу” із суб'єктів в об'єкти “модифікованого” економічного та соціального життя - “в інтересах” досягнення гармонії, системної рівноваги, 
сталого зростання продуктивної спроможності національних економік тощо. Обгрунтування - (за комфортне життя) будь-чого і для буть-кого - не інноваційна технологія, вона стара, як світ.

Тенденції змін у системі ціннісних орієнтирів економіки та суспільства, окремих регіонів, соціальних груп, окремих суб'єктів глобалізованого економічного життя на планеті, які виникають унаслідок нанотехнологічної революції, викликають серйозну занепокоєність якістю парадигмальної орієнтації, як у полі наукових досліджень сутності та перспектив процесів, що відбуваються, так і в полі політичної діяльності, економічної політики, 3 позицій збереження та оптимальної орієнтації розвитку людської цивілізації.

У підходах до формування парадигмальної спрямованості наукових досліджень у соціальних науках, парадигмальної орієнтації політиків та економомічної політики, визначення парадигми економічного розвитку глобалізованого суспільства, домінує стан дуалізму, невизначеності та ризиків щодо прогнозування майбутнього місця та ролі людини у суспільному виробництві, у духовному, культурному, цивілізаційному полі планети. Однак, за будь-яких умов, не слід забувати, що людина залишається людиною лише за умови оволодіння та володіння усіма надбаннями людського розуму в соціалізованому середовищі: здатністю до праці та розумінням необхідності брати участь у суспільному виробництві, у тій чи іншій формі; здатністю та необхідністю постійно спілкуватися 3 собі подібними, відчуваючи та використовуючи емоції, емоційний стан свій та іншого суб'єкта відносин; здатністю відчувати радість та приносити радість іншим людям тощо. Людина "нанотехнологічна" вже не повноцінна людина. Отже трансгуманітарна парадигма розвитку яка націлює на використання досягнень четвертої (i не тільки) промислової революції для перетворення людини у надлюдину фактично націлює цей розвиток на завершення існування "природної" людської цивілізації, навіть не намагаючись відповісти на питання які ж внутрішні можливості та резерви розвитку ще не відкриті у самій людині; що станеться із суспільством, світом власне людей, що буде із сотнями мільйонів (мільярдами) людей (і чи зможуть вони залишатися людьми) в умовах стрімкої роботизації усіх сфер життя на планеті?

Такі висновки власне i викликають потребу, у процесі визначення стратегічних цілей економічного розвитку та використання результатів нанотехнологічної революції (до того ж у глобальних масштабах) попереднього глибокого філософського осмислення та прогнозування можливих непоправних етичних, духовних, соціальних втрат існуючої людської цивілізації. Адже 
ступінь ризиків від прийняття поспішних доленосних рішень не піддається людській уяві.

\section{Список використаних джерел}

1. Глобальное будущее 2045: Антропологический кризис. Конвергентные технологии. Трансгуманистические проекты: Материалы Первой Всероссийской конференции, Белгород, 11 - 12 апреля 2013 г. / Под ред. Д. И. Дубровского, С. М. Климовой. - М.: «Канон+» РООИ «Реабилитация», 2014. - 352 с.

2. Ильин В.В. Философия истории. - М.: Изд-во Моск. Ун-та, 2003. - $380 \mathrm{c}$.

3. Кумбс Френсис. Мотиватор. Пер. с англ. М.: PUBLISHHING LTD. 2006. - 318 c.

4. Назаретян А. П. XXI век и «устаревшая философия» (по поводу юбилейного доклада Римскому клубу) // Общественные науки и современность. 2018. № 4. - С. $160-177$.

5. Проблема совершенствования человека (в свете новых технологий): Трансгуманизм и проблема социальных рисков. Редукционизм как соблазн наук о человеке. Об идолах и идеалах биотехнологического самоизобретения человека. Как возможен совершенный человек? / Отв. ред. Г. Л. Белкина; Ред.-сост. М. И. Фролова. Предисл. С.Н. Корсакова. М. ЛЕНАНД, 2016. - 272 с.

6. Рейнерт Эрик С. Спонтанный хаос. Экономика эпохи рецессии / Эрик С. Рейнерт; [пер. с норв. А.В. Наумовой]. - М.: Политическая энциклопедия, 2017. - 190 с.

Лагутін В.Д., д.е.н., професор, Київський національний торговельноекономічний університет

\section{ПЕРСПЕКТИВИ ОНОВЛЕННЯ МЕТОДОЛОГІї ЕКОНОМІЧНОЇ НАУКИ У ХХІ СТОЛІТТІ}

Методологія систематизує методи, способи і прийоми пізнання об'єктивної дійсності, забезпечення достовірності отриманих знань про об'єкт дослідження, їх відповідність предмету дослідження, а також $\epsilon$ засобом обгрунтування результатів і висновків проведеного дослідження. Проте таке розуміння методології науки, розкриває іiі 
сутність лише в самому загальному вигляді, а отже, необхідною $є$ подальша конкретизація цього поняття та його поглиблене дослідження.

Роль методології полягає в тому, що за іiі допомогою науковці беруться вирішувати проблеми, які на даний момент наукою невирішені. Фактично це й становить зміст наукової діяльності. Наукове переосмислення проблеми, перехід від одних наукових завдань до інших, що дозволяє глибше розкрити сутність економічних процесів і явищ - це теж напрям наукової діяльності, не менш важливий, але іншого плану. Він вимагає дещо іншої методології досліджень. Прагматичне використання різних методологічних підходів до дослідження економічних проблем, як показує уся історія економічної науки, часто стає еклектикою. Така еклектична методологія, тим більше із наголосом на суб'єктивізм дослідника, не приводить до реально нових наукових результатів досліджень.

Будь-яке теоретичне економічне дослідження грунтується на певних методологічних принципах, серед яких найважливішими є: фундаментальність дослідження, на відміну від поверхових або функціональних зв' язків; наявність грунтовного філософського базису, що передбачає єдність онтологічного, гносеологічного, аксіологічного і праксеологічного підходів; розуміння сутності, змісту та форми процесів та явищ; розгляд глибинних соціально-економічних процесів на основі виділення причинно-наслідкових зв'язків; врахування тенденцій і закономірностей розвитку громадянського суспільства та його економічної системи; здійснення об'єктивного аналізу об'єктивної дійсності, коли предметною сферою дослідження виступають економічні відносини; виділення вартості як основоположної категорії дослідження; аналіз комплексу інтересів суб'єктів економічних відносин в контексті їх системної єдності та суперечностей; обов'язковість «виходу» в прикладній сфері на проблеми формування, реалізації та вдосконалення економічної політики держави; можливість застосування отриманих наукових висновків та результатів в наступних дослідженнях конкретних економічних наук.

Низький рівень методології перетворює економічну науку 3 активного пізнавального засобу, який постійно вдосконалюється самими дослідниками в механічний конгломерат незаперечних істин (за відомою метафорою Р. Коуза знань на «класній дошці»), ранг яких не піднімається вище пропедевтики.

Історія економічної думки знає цілий ряд етапів радикального оновлення методології науки. Перша половина XIX ст. - це оновлення 
методології економічної науки на основі діалектики, базисом якої була німецька філософія. Найповніше цю методологію (у формі діалектичного та історичного матеріалізму) використав у своїх проявах К. Маркс, насамперед, у трьох томах «Капіталу».

Друга половина XIX ст. - це вихід на перший план методології неокласичного мікроекономічного аналізу. Вперше системно вклав основні положення цієї методології А. Маршал. 3 цього часу неокласична ортодоксальна парадигма утворила світовий мейнстрим економічної теорії, іiї представники найчастіше отримують Нобелівські преміï. Сам термін «neoclassical economics» вперше використав американський інституціоналіст Т. Веблен для позначення сучасних йому ортодоксальних економістів [1, Р. 141]. Усі методологічні припущення неокласичної теорії - це сильні спрощення. Іншими словами, методологічно вони більш висловлюють побажання економістів, ніж реальність.

Середина XX ст. - це час розроблення методології кейнсіанського макроекономічного аналізу. Роль і значення кейнсіанства, а потім неокласики як окремої школи економічної думки тоді навіть перевищувала неокласичну концепцію. Проте, у кінці 1970x pp. все закінчилось поразкою неокейнсіанства і новим розквітом методології неокласики в її монетаристській версії.

У XX ст. досить потужно розвивалася марксистсько-ленінська теорія (методологія), яка в кількох десятках країн світу стала навіть офіційною державною ідеологією, а централізоване планування на противагу ринку стало основним засобом реалізації економічної політики держави. Неоліберальна концепція звузила межі свого поширення. Проте в кінці XX ст. все змінилося перемогою неолібералізму (так званий кінець історії за Ф. Фукуямою).

Навіть при поверхневому погляді на національність лауреатів Нобелівської премії 3 економіки можна зробити висновок про домінування в наукових дослідженнях англомовного наукового співтовариства, що грунтується на засадах неокласичної «економікс». Насамперед, американські університети і наукові центри залишаються переважними джерелами формування теоретичних і методологічних знань про економіку. Таке домінування пов'язано у тому числі й 3 мовою дослідження і викладення його результатів. Англійська мова $є$ мовою світової науки, тому англомовні книги та періодика набувають глобального поширення, ставлячи авторів із інших країн в неконкурентне становище. Вагомим є й організаційний фактор економічні дослідження у США добре фінансуються. 
Методологія неокласики і неолібералізму в їх західній версії «економікс» (першість принципу «laissez fair») сьогодні $\epsilon$ пріоритетною. Проте глобальна фінансово-економічна криза 20082009 рр. істотно підірвала легітимність неолібералізму [2, С. 40].

Найперспективнішою на початку XXI ст. для економічної науки $\epsilon$, на нашу думку, синергетична методологія з її ефективними методами дослідження емерджентних систем. Синергетична методологія, що $є$ більш високою формою наукового пізнання порівняно, наприклад, із діалектикою, не відкидає ії конкретні методи і прийоми мислення як невірні і застарілі. Синергетика включає діалектику у свій зміст у переробленому («знятому») вигляді як необхідний момент теоретичного освоєння предмету, даючи їй у XXI ст. сучасну наукову інтерпретацію.

В умовах методологічного безладу в науці висновки як результат дослідження не можуть бути достовірними, в кращому разі вони лише формально відповідатимуть певним вимогам. Прикладні рекомендації та пропозиції при цьому $\epsilon$ малообгрунтованими i відображають викривлений погляд на економічну дійсність, а отже, не можуть забезпечити іiі позитивне реформування. Маніпулювання результатами досліджень - прямий крок до популізму в державній економічній політиці.

\section{Список використаних джерел}

1. McCormick K. R. Veblen in Plain English. A Complete Introduction to Thorstein Veblen's Economics. Youngstown. New York: Cambria Press, 2006. 144 p.

2. Єщенко П.С., Арсеєнко А.Г. Нова парадигма розвитку економіки - настійливе веління нашого часу // Економіка і прогнозування науковий журнал, 2011. - № 1. - С. 28-47.

Лебедева Л. В. ,

к. е. н., доцент,

Київський національний торговельно-економічний університет

\section{ПРЕДМЕТ ДОСЛІЖЖННЯ СУЧАСНОЇ ЕКОНОМІЧНОЇ} НАУКИ 
У науковому колі економістів, як вітчизняних, так і зарубіжних, вже доволі довго обговорюється питання про застарілість положень неокласичної парадигми та іiі невідповідність економічним реаліям XXI ст. Зокрема, світова фінансова криза 2008-09 рр., що мала серйозні економічні наслідки у вигляді скорочення національного виробництва, різкого зростання безробіття та збільшення державного боргу країн світу, різко похитнула позиції неокласичної парадигми. У відповідь на кризу у ряді країн було запроваджено програми жорсткої економії, спрямовані на контроль дефіциту бюджету та зовнішню заборгованість, з надією на те, що економіка може відновити темпи економічного зростання. Але, заходи жорсткої економії лише погіршили наслідки кризи та додатково зменшили сукупний попит. Отже, фінансова криза підкреслила недоліки існуючої парадигми економічної теорії, як на мікро-, так і на макроекономічному рівнях, та з точки зору забезпечення адекватного та належного розуміння того, як економіка працює. Як наслідок, сучасна економічна наука не може слугувати надійною платформою для вирішення економічних проблем, ня яку могло б спиратися керівництво країн. Домінуюча економічна парадигма нехтує складністю системних взаємодій в економіці, роллю та місцем поведінкових та психологічних факторів, що лежать в основі функціонування сучасних економік, а також системною залежністю економік країн від природних ресурсів.

Зарубіжні дослідники виокремлюють наступні економічні підходи, які розкривають проблеми розвитку економіки сучасності, що повинно бути відображено у предметі сучасної економічної науки:

По-перше, серед західних економістів досить поширеним $\epsilon$ дослідження впливу проблем збереження навколишнього середовища, утилізації шкідливих відходів, проблеми економічного розвитку та добробуту людини (нерівномірність у розподілі доходів, бідність), питання стійкого розвитку, проблеми меж економічного зростання, державної екологічної політики та ін. на розвиток сучасних економік, чим займається спеціальна дисципліна економіка навколишнього середовища (Ecological economics). Дослідники, які займаються даними проблемами, стверджують про необхідність включення економіки навколишнього середовища до домінуючої економічної парадигми [1]. Наприклад, хоча домінуюча теорія економічного зростання припускає, що зростання обсягів виробництва залежить від збільшення кількості працівників та продуктивності їх праці, капіталу та знань, сучасні дослідники [2] стверджують, що економічне зростання краще пояснюється так званою «корисною роботою» (useful work) як фактору виробництва. У сучасних економіках корисна робота 
значною мірою залежить від наявності відносно дешевих та високоякісних енергоносіїв. Крім того, еколого-економічний аналіз свідчить, що перехід до стійкої економіки з низьким рівнем викидів вуглецю потребуватиме заміни цілі збільшення темпів економічного зростання як основної мети державної політики на ціль забезпечення екологічної рівноваги в країні та стійкого економічного розвитку [3]. Економісти йдуть навіть далі у цьому питанні й пропонують переходити до сучасної державної політики низького або нульового росту $[4,5]$ та від'ємного росту $[6,7]$ обгрунтовуючи свої положення тим, що економічне зростання не може підтримуватися безмежно на планеті з обмеженими ресурсами.

По-друге, дослідження 3 поведінкової економіки (behavioral economics) детально показали обмежену раціональність людей при прийнятті економічних рішень і залежність від упереджень та поведінки інших людей. Наприклад, для людей значно важливішим $\epsilon$ уникнути втрат в даний час, ніж отримати потенційну вигоду чи мінімізувати значні витрати в майбутньому [8]. Цей тип поведінки не враховується в моделі раціональної економічної людини в якості чи передбачення або принаймні раціонального очікування, які лежать в основі більшості макроекономічних моделей.

По-третє, інституціоналісти наголошують на визначній ролі, яку грають інститути, включаючи законодавчі обмеження та соціальні норми у сучасних економіках [9]. Наприклад, приватна власність має вагоме значення не тільки у забезпеченні засобами обміну, але й слугує основою для залучення капіталу, $є$ центральною категорією у поточних економічних викликах [10]. Як відомо, кредитування позичальників у США при купівлі житла, по якому вони не змогли продовжувати виплати, було однією 3 причин фінансової кризи, оскільки сек'юритизація цих кредитів поширювала ризики в усьому світі. Той факт, що роль банків і фінансове регулювання значною мірою ігнорується у макроекономічних моделях центрального банку, може допомогти пояснити, чому ці інститути недостатньо враховані при формуванні економічної політики.

По-четверте, еволюційні економісти (evolutionary economists) стверджують, що технологічні та інституційні зміни в економічних системах слід розглядати як динамічні еволюційні процеси, та не намагатися їх пояснити з точки зору загальної рівноваги [11]. Це означає, що зміни в економіці можуть бути дуже ситуативними, та вимагати прийняття неоптимальних рішень у державній політиці, якто підтримка інновацій на ранніх стадіях розвитку. 
Сучасна економіка знань відрізняється від предмета «економікс» не менше, ніж економіка первісного або традиційного суспільства, адже результати виробництва в ній обмінюються ні за законом граничної корисності, ні за законом вартості. Продукти інтелектуальної діяльності, у т.ч. програмні продукти, розповсюджуються без витрат та продаються за диференційованими цінами, які залежать від уявлення продавця про його вартість i соціального статусу покупця. 3 однієї сторони зростає частка суспільних благ, що розповсюджуються безкоштовно, а 3 іншої 3'являються товари модних брендів, що продаються за завищеною ціною, яка зовсім не відповідає ціні аналогів, чи навіть товарів 3 кращою якістю. Товари та послуги стають на стільки різноманітними, що людині стає просто не можливо раціонально їх порівняти виходячи зі своїх об'єктивних потреб і доходів.

Економіка сучасності $є$ складною адаптивною системою, що постійно змінюється, яка значно відрізняється від моделі, що аналізується в межах неокласичної парадигми. До то го ж, зміни в економіці, пов'язані з провідною роллю інновацій та знань, повинні бути враховані при визначені предмета сучасної економічної теорії й включають наступні:

- економіка є відкритою динамічною системою, системою, що не перебуває у рівновазі. Економіка як жива система, що еволюціонує у більш складну систему 3 різноманітними видами виробництва і споживання, рідко може досягнути стану рівноваги. Більш того, в процесі еволюції вона все більше віддаляється від цього стану, адже іiі розвиток має нелінійний характер, для якого характерним $\epsilon$ велика турбулентність. Отже, оскільки економіка $є$ живою системою, предметом економічної науки має бути вивчення закономірностей іiі розвитку i, відповідно, механізмів іiі ускладнення i утримання стійкості в процесі підвищення різноманітності господарської діяльності та їі результатів;

- економіка складається 3 неоднорідних економічних суб'єктів, які не приймають оптимальних рішень, але здатні вчитися i адаптуватися з часом;

- економічні суб'єкти взаємодіють через різні мережі;

- $\quad$ макромоделі виникають 3 взаємодії економічних суб'єктів мікрорівня, які у свою чергу впливають на побудову макромоделі;

- інформація та знання змінюють процес виробництва, перетворюючись в один з основних його факторів.

3 чого робимо висновок, що предметом сучасної економічної науки є процес розвитку відкритих динамічних економічних систем, 
які побудовані на основі мережевих зв'язків між економічними суб'єктами, що діють адаптивно, комбінуючи обмежені економічні ресурси.

\section{Список використаних джерел}

1. Common M., Stagl S. Ecological Economics: An Introduction. Cambridge University Press, 2005. 560 p.

2. Robert U. Ayres, Jeroen C.J., M. van den Bergh, Dietmar Lindenberger, Benjamin Warr. The underestimated contribution of energy to economic growth. Structural Change and Economic Dynamics. 2013. Volume 27. Pages 79-88. https://doi.org/10.1016/j.strueco.2013.07.004

3. Jackson T., Victor P. Towards an Ecological Macroeconomics, INET Annual Plenary Conference :Paradigm Lost: rethinking economics and politics, Berlin, April 2012 https://www.ineteconomics.org/uploads/papers/victor-peter-berlinpaper-draft-w-Tim-Jackson.pdf;

4. Malmaeus J. Mikael, Alfredsson Eva C. Potential Consequences on the Economy of Low or No Growth - Short and Long Term Perspectives. Ecological Economics. 2017. V.134. pp. 57-64;

5. Cosme, I., Santos, R., and O'Neill, D.W. Assessing the degrowth discourse: A review and analysis of academic degrowth policy proposals. Journal of Cleaner Production. 2017. V.149. P. 321-334. doi: 10.1016/j.jclepro.2017.02.016;

6. Martin Weiss, Claudio Cattaneo. Degrowth - Taking Stock and Reviewing an Emerging Academic Paradigm. Ecological Economics, Volume 137, 2017, pp. 220-230;

7. Heikkinen T. (De)growth and welfare in an equilibrium model with heterogeneous consumers. Ecological Economics. Volume 116, August 2015, Pages 330-340

8. Kahneman D., Thinking, fast and slow. Farrar, Straus \& Giroux, 2011. 499 pp.

9. North D., Institutions, Institutional Change and Economic Performance. Cambridge University Press, 1990. 152 p.

10. Griethuysen, P. Bona diagnosis, bona curatio: How property economics clarifies the degrowth debate. Ecological Economics, 2012, 84(0):262 $-269$

11. Freeman C., Louca F.: As times goes by. From the Industrial Revolutions to the Information Revolution. Oxford University Press 2001, 407 p. 
Лепак П.А., аспірант,

Київський національний торговельно-економічний університет

\section{ДОСЛІДЖЕННЯ ЦННІСНИХ ОРІЄНТИРІВ СУСПІЛЬСТВА, ЗАСОБАМИ WORLD VALUES SERVEY}

Становище, в якому знаходиться сьогодні українське суспільство, здебільшого показує відсутність чіткої системи цінностей, яке призводить до певних диспропорцій у поведінкових стратегіях учасників ринкової взаємодії. 3 огляду на це, витікає збільшення державних витрат на соціальні виплати, що в умовах військового конфлікту та зумовленої ним економічної кризи є великим тягарем для державного бюджету. Такий дисбаланс функціонування економічної системи, та постійної іiі реформації зрештою може призвести до іiі занепаду. Вирішити цю проблему можна шляхом усунення причини іiі виникнення, а саме побудови економічної культури суспільства, через систему цінностей, яка б відповідала вимогам сьогодення, базувалася б на вітчизняному досвіді та враховувала національні особливості ринкової взаємодії.[1] Необхідність досліджень цінностей українського суспільства $є$ викликаною необхідністю у формуванні економічної культури суспільства, а турбулентність в економічних та політичних змінах в країні, що знаходиться у стані становлення потребує побудови фундаменту для становлення ринководемократичних форм відносин. Методологічні основи досліджень ціннісних показників потребують наукового доробку та удосконалення, зокрема в частині поєднання отриманих соціологічних данних з економіними показниками та їх використання у економіних наукових дослідженнях.

В умовах обмеженості українському досліднику приходиться стикатись з рядом викликів, головний з яких - пошук статистичних та оперативних даних. Опитування про ціннісні орієнтири суспільства $€$ масштабним та дорого вартісним. Тому аналіз вже проведених досліджень та опитувань може допомогти у формуванні гіпотез та можливих подальших досліджень у сфкрі ціннісних орієнтацій суспільства. Один з таких - World Values Servey (Світове дослідження цінностей - досл. переклад)[4]. Протягом багатьох років WVS продемонструвала, що переконання людей відіграють ключову роль у 
економічному розвитку, виникненні та розквіті демократичних інститутів, зростанні гендерної рівності та мірі, та ефективному державному управлінню. Деякі ключові напрями цих досліджень описані нижче.

Традиційні цінності проти світських-раціональних цінностей $\mathrm{i}$ значення виживання проти цінностей самовираження. Глобальна культурна карта [3] показує, як десятки суспільств розташовані на цих двох вимірах. Переміщення вгору на цій карті відображає перехід від традиційних цінностей до світського-раціонального i рухається вправо, відображає перехід від цінностей виживання до цінностей самовираження.

Традииійні иүінності підкреслюють важливість релігії, батьківсько-дитячих зв'язків, поваги до влади і традиційних сімейних цінностей. Люди, які приймають ці цінності, також відкидають розлучення, аборти, евтаназію та самогубство. Ці суспільства мають високий рівень національної гордості та націоналістичного світогляду.

Світські ращіональні цінності мають протилежні переваги до традиційних цінностей. У цих суспільствах менше уваги приділяється релігії, традиційним сімейним цінностям і авторитету. Розлучення, аборти, евтаназія та самогубство вважаються відносно прийнятними. (Самогубство не обов'язково більш поширене).

Значення виживання роблять акцент на економічну i фізичну безпеку. Це пов'язано $з$ відносно етноцентричним світоглядом і низьким рівнем довіри і терпимості.

Значення самовираження надають високий пріоритет охороні навколишнього середовища, зростаючу толерантність до іноземців, геїв і лесбіянок і гендерну рівність, а також зростаючі вимоги до участі у прийнятті рішень в економічному та політичному житті.

Прагнення до демократії. Прагнення до вільного вибору та автономії $\epsilon$ універсальним людським прагненням, але воно не $\epsilon$ пріоритетом, коли люди, відчувають, що виживання невизначене. Поки фізичне виживання залишається невизначеним, прагнення до фізичної та економічної безпеки, як правило, займає вищий пріоритет, ніж демократія. Коли основні фізіологічні потреби та потреби у безпеці виконуються, зростає наголос на цінностях самовираження. Результати WVS демонструють, що масові цінності самовираження є надзвичайно важливими для виникнення та розквіту демократичних інститутів у суспільстві. Індустріалізація та підйом постіндустріального суспільства призводить до того, що зміна поколінь призводить до того, що цінності самовираження стають все 
більш поширеними, а країни з авторитарними режимами наражаються на зростаючий масовий тиск на політичну лібералізацію.

Розширення прав і можливостей громадян. Дослідники WVS визначили, як розширення можливостей звичайних громадян може призвести до демократії. Цей процес людського розвитку дає змогу і мотивує людей вимагати демократії, що призводить до зміни режиму, що дає право людям керувати своїм життям. Зростаючі ресурси дій (такі, як освіта) і поширення цінностей самовираження призводять до виникнення демократичних інститутів, які дають людям змогу отримувати зростаючу свободу вибору в тому, як жити власним життям і вибирати свій політичний режим.

Глобалізація та конвергенційні значення. Протягом останніх 30 років у світі спостерігалися глибокі зміни в політичній, економічній та соціальній сферах, а також у швидкому технологічному прогресі. Це часто пояснюється явищем глобалізації. Ринки капіталу сьогодні інтегровані по всьому світу, а фільми та книги обмінюються світом за кілька секунд. Сотні мільйонів людей відвідують ті ж самі веб-сайти, дивляться ті ж телеканали і сміються над тими ж жартами. Ці приклади сприяли переконанню, що глобалізація приносить збіжні цінності або McDonaldization світу. Фактично аналіз даних Світового опитування цінностей показує, що за останні три десятиліття масові цінності не збігаються. Норми, що стосуються шлюбу, сім'ї, гендерна та сексуальна орієнтація демонструють різкі зміни, але практично всі прогресивні індустріальні суспільства рухаються в одному напрямку, приблизно з аналогічною швидкістю. Це призвело до паралельного руху, без зближення. Більше того, хоча економічно розвинені суспільства змінювалися досить швидко, країни, які залишилися економічно застійними, показали незначну зміну цінності. Як наслідок, зростає розбіжність між переважаючими цінностями в країнах з низьким рівнем доходу та країнах з високим рівнем доходу.

Гендерні цінності. Результати WVS свідчать, що підтримка гендерної рівності не $\epsilon$ лише наслідком демократизації. Вона $\epsilon$ частиною більш широких культурних змін, які перетворюють промислові суспільства 3 масовими вимогами до все більш демократичних інституцій. Хоча більшість населення світу все ще вважає, що чоловіки роблять кращих політичних лідерів, ніж жінки, ця точка зору згасає в розвинутих індустріальних суспільствах, а також серед молоді в менш процвітаючих країнах.

Релігія. Дані Всесвітнього опитування цінностей охоплюють кілька важливих аспектів релігійної орієнтації людей. Один з них відстежує, як люди беруть участь у релігійних службах і наскільки 
важливе значення вони надають своїм релігійним переконанням. За даними 2000 року, 98\% населення Індонезії сказали, що релігія є дуже важливою в їхньому житті, тоді як у Китаї лише три відсотки вважають релігію дуже важливою. Інший аспект стосується ставлення людей до відносин між релігією та політикою і чи схвалюють вони релігійних речників, які намагаються впливати на урядові рішення та переваги голосування людей.

Щастя і задоволення життя. WVS показав, що з 1981 по 2019 рік щастя зросло в 45 з 52 країн, для яких доступні довгострокові дані. 3 1981 року економічний розвиток, демократизація i зростання соціальної толерантності збільшили ступінь, до якого люди сприймають, що вони мають вільний вибір, що в свою чергу призвело до більш високого рівня щастя в усьому світі. Сайт популярної статистики Nationmaster публікує спрощену світову шкалу щастя, отриману з даних WVS. Веб-сайт WVS надає доступ до даних WVS, дозволяючи користувачам проводити більш складні аналізи, такі як порівняння рівнів щастя в часі або між соціально-економічними групами. Одним з найяскравіших зрушень, виміряних WVS, було різке зниження щастя в Україні та багатьох інших колишніх комуністичних країнах протягом 1990-х років.

Аналіз цих ціннісно орієнтаційних даних [2], в більш ніж 100 країнах світу за останні 20 років. Дають змогу аналізувати та робити прогнозування в економічному та культурно - політичному розвитку країн, і не тільки. Доступ є безкоштовним. Побудова Порівняльних графіків та Моделей можлива як за допомогою інформаційного конструктора, так і перенесенням даних в інші програми для моделювання та прогнозування.

Список використаних джерел:

1. Глубіш Л.Я. Система цінностей як базис формування економічних інтересів стейкхолдерів як вектор економічних ефектів від їх реалізації / Глубіш Л.Я.. // ЕКОНОМІКА I СУСПІЛЬСТВО. - 2017. - №9. - С. 171-175.

2. Data \& Documentation [Електронний ресурс] - Режим доступу до pecypcy: http://www.worldvaluessurvey.org/WVSContents.jsp.

3. Live Cultural map - WVS (1981-2015) [Електронний ресурс] Режим доступу до pecypcy: http://www.worldvaluessurvey.org/WVSContents.jsp.

4. World Values Survey [Електронний pecypc] - Режим доступу до pecypcy: http://www.worldvaluessurvey.org/wvs.jsp. 
Максимюк В.А., д.ф.-м.н., старший науковий співробітник Інститут механіки ім. С.П. Тимошенка НАН України

\section{ЕКОНОМІЧНА ТЕОРІЯ 3 ПОГЛЯДУ ФІЗИКИ}

Вступ. Наразі поєднання фізичного й економічного йде, в основному, трьома шляхами: "фізична економіка" [1], "фізична економія" [2], "еконофізика" [3]. Попри лексичну подібність між ними розбіжностей більше, ніж спільного. Спільне полягає в певному застосуванні фізичних понять до економії. Розбіжності лежать у розумінні теорії вартості, а саме, що $є$ джерелом і що $є$ мірилом вартості.

Л. Ларуш, родоначальник фізичної економії, критикував як політекономістів, так і фізіократів. Наприклад, щодо останніх - "the Physiocrats argued that all net growth of the wealth of society per capita is generated solely as the "bounty of nature," not man's productive labor" [1, c. 46-47]. Тобто джерелом вартості він вважав працю, переважно інтелектуальну, а за мірило вартості пропонував фізичні величини. 3 огляду на такий різнобій у розумінні джерела і мірила вартості можна стверджувати, що в основі фізичної економії лежить гібридна трудова теорія вартості.

Фізична економія бере свої витоки від фізіократів, з праць С. Подолинського [4] і знайшла свій подальший розвиток в працях М. Руденка [2]. Щодо згаданого "bounty of nature" М. Руденко мав абсолютно протилежну думку [2, с. 70]: “сам капітал, не можна виводити 3 експлуатації праці - це справді дар Природи. Він загальний для всього людства". Джерелом вартості М. Руденко вважав сонячну енергію, а мірилом -зерно, тобто теж енергетичну величину. Тому його можна вважати прихильником цілісної енергетичної теорії вартості. Разом з тим, М. Руденку, який вказував [2, с. 70], що "двозначність у розумінні додаткової вартості, що була властива фізіократам, є об'сктивно науковою", а ще більше С. Подолинському, який вважав [4, с. 251], що "Кене має рацію ... точно так само має рацію i Сміт", був притаманний певний дуалізм щодо оцінки вкладу у вартість енергії природи та праці людини. 
Еконофізика спершу виникла для аналізу фінансових ринків методами статистичної фізики. В подальшому коло задач та методів еконофізики значно розширилось [3]. На деяких природничих факультетах українських університетів вже відкриваються відповідні спеціальності. Проте еконофізика не цікавиться джерелами вартості, вона цілком вписується в існуючу парадигму політекономії, хоча деякі автори інколи продовжують цитувати Л. Ларуша.

Грунтовний порівняльний аналіз теоретичних положень фізичної економії та фізичної економіки дано в праці Л. Воробйової [5]. Подальший виклад буде йти в рамках фізичної економії. Буде показано, як проявляються закони фізики, переважно механіки, в суспільстві безпосередньо та опосередковано.

\section{1. Рівність та справедливість 3 погляду фізичної економії.} Рівність та справедливість - невмирущі поняття. Вони $\epsilon$ відображенням понять симетрії та законів збереження у фізиці (табл.1). В аналітичній механіці, яку Гамільтон назвав "математичною поемою", симетрія дії щодо простору і часу веде до законів збереження. А принцип найменшої дії веде до законів руху.

Табличя 1

\begin{tabular}{|c|c|c|c|}
\hline \multicolumn{2}{|c|}{ Механіка } & \multicolumn{2}{c|}{ Економія } \\
\hline \multicolumn{2}{|c|}{ Дія } & \multicolumn{2}{c|}{ Витратність } \\
\hline Симетрія & Найменша & Рівність & Найменша \\
\hline Закони & Закони & Закони & Закони \\
збереження & руху & справедливості & розвитку \\
\hline
\end{tabular}

Конкретніше, із симетрії дії відносно часу, простору та напрямку згідно з теоремою Нетер випливають закони збереження, відповідно енергії, імпульсу та моменту імпульсу (табл.2).

\begin{tabular}{|l|l|l|}
\multicolumn{1}{|c|}{ Фізика } & \multicolumn{1}{|c|}{ Таблицяя 2 } \\
\hline Принцип найменшої дії & \multicolumn{1}{|c|}{ Прономія } \\
\hline \multicolumn{1}{|c|}{ Симетрії } & \multicolumn{2}{|c|}{ Рівності } \\
\hline 1.Час & 1.Покоління \\
2.Простір & 2.Індивідуум, нація \\
3.Напрямок & 3.Напрям думки, (ідеологічна інваріантність) \\
\hline \multicolumn{1}{|c|}{ Закони збереження } & \multicolumn{1}{|c|}{ Закони справедливості } & \multicolumn{1}{|c|}{ Закони розвитку } \\
\hline 1.Енергії & 1.Блага між поколіннями & 1. Сталого \\
2.Імпульсу & 2.Ініціатива & 2. Рівноважного \\
3.Моменту імпульсу & 3.Інформація & 3. Індиферентного \\
\hline
\end{tabular}


У економії замість законів збереження будуть закони справедливостей [6]. Так, з інваріантності в часі має випливати закон збереження енергії (благ) між поколіннями, що можна назвати енергетичною справедливістю, а відповідний закон розвитку - сталим. Це певною мірою $є$ співзвучним з поняттям власності поколінь, яке запропонував В. Шевчук [7].

Очевидно, якщо порушується симетрія або рівність, то будуть порушуватися відповідні закони в природі або суспільстві.

2. Механіка фізичної праці. Фізична праця людини має 3 погляду механіки двоїстий характер - енергетичний або імпульсний [6]. До фізичної праці енергетичного характеру відноситься така, де людина переважно виконує над тілом механічну роботу Наприклад, піднімання тіла, процеси 3 тертям чи 3 пластичними деформаціями. В сільському господарстві - копання, розрихлювання, ущільнення, збирання. Очевидно, що така праця є адитивною щодо затраченої енергії людини та кількості працівників.

До фізичної праці імпульсного характеру відноситься така, де людина переважно змінює імпульс тіла чи перешкоджає його набуття. Наприклад, утримування тіла під дією сили тяжіння, горизонтальне переміщення без тертя, опускання вниз, розкидання, процеси 3 руйнуванням. В сільському господарстві - сіяння, косіння, молотіння, розмелювання.

Наглядним прикладом праці імпульсного характеру є задача забивання палі в грунт. Тут корисним результатом $\epsilon$ глибина забивання. Інтуїтивно ясно, що вигідно взяти масивніший інструмент. Процес проникнення циліндричного діаметром $d$ твердого тіла масою $m$ вагою $q=m g$ в грунт за невеликих швидкостей приблизно описується емпіричною так званою [8] березанською формулою:

$$
h=K \frac{q v}{d^{2}},
$$

де $h$ - глибина проникнення; $v$ - початкова швидкість інструменту (палі) перед проникненням в поверхню грунту; $K$ - калібрувальний коефіцієнт, який залежить від властивостей грунту.

Формула (1) була встановлена в 1912 р. на острові Березань в Чорному морі під час стрільб артилерійськими снарядами в грунт. Вона може бути застосована також для оцінки заглиблення будівельних елементів в грунт [8]. Формула (1) може бути отримана також теоретично в припущенні наявності сили тертя, пропорційної швидкості. Видно, що глибина проникнення є пропорційною імпульсу $p=m v$ палі 


$$
h=K \frac{q v}{d^{2}}=K \frac{m g v}{d^{2}}=\frac{K g}{d^{2}} m v=\frac{K g}{d^{2}} p .
$$

Якщо вважати глибину проникнення мірилом корисності праці, то забивання праці буде працею переважно імпульсного характеру. Переважно тому, що є також інші формули, які точніше описують процес проникнення за більших швидкостях.

За заданої кінетичної енергії $E_{k}=m v^{2} / 2$ імпульс набирає величину

$$
p=\sqrt{2 m E_{k}}
$$

3 формули (2) видно, для збільшення продуктивності праці імпульсного характеру потрібно збільшувати масу інструменту. Проте збільшення маси обмежується можливостями однієї людини. Вихід полягає в застосуванні колективного зусилля до одного інструмента, коли додаються механічні сили й, відповідно й імпульси $p=m v=F t$. Отже, фізична праця імпульсного характеру є адитивною щодо часу працювання та кількості розрізнених працівників, але не є адитивною щодо потужності одного працівника та кількості працівників на один колективний інструмент.

Така особливість фізичної праці імпульсного характеру пояснює доцільність колективної праці. Інший шлях збільшення продуктивності праці імпульсного характеру полягає у використанні простих механізмів. Хоча прості механізми не дають виграшу в механічній роботі, але вони дають виграш у фізичній праці імпульсного характеру.

Дуалізм фізичної праці вимагає перегляду методики іiї суспільної оцінки 3 врахуванням структури характеру праці та кількості працівників.

3. Продуктивність простих механізмів i капіталу. С. Подолинський сформулював ключове питання економії щодо продуктивності праці, природи і капіталу [4, с. 251]. У своїй відповіді він, погоджуючись і з Кене і зі Смітом, визнав продуктивність перших двох чинників, проте нічого не сказав про капітал. Концепція праці імпульсного характеру дозволяє до розгляду чинників продуктивності включити ще й прості механізми [6].

За певних умов продуктивними можуть бути прості механізми i капітал. Такі умови виникають в процесі виробництва з використанням переважно фізичної праці імпульсного характеру на відміну від фізичної праці енергетичного характеру, коли такі умови не виникають. 
Зовнішні механічні ознаки фізичної праці імпульсного характеру такі: вигідно оперувати з великими масами, вигідна велика механічна потужність людини, вигідні прості механізми, вигідні процеси 3 крихким руйнуванням. До соціальних зовнішніх ознак можна віднести: вигідність колективної праці, вигідність використання фізично сильніших працівників. Якщо простий механізм (інструмент) дає виграш в енергії для виконання механічної роботи, то це $\epsilon$ праця імпульсного характеру, якщо ні - то це праця енергетичного характеру.

Колективна праця може бути організована кількома способами: толока, відробіток, позика і нарешті - капітал. Роль капіталу полягає в організації праці імпульсного характеру, тобто капітал заміщає простий механізм. Отже, капітал -важіль економіки, майже в прямому сенсі слова.

4. Дуалізм грошей. Проблему дуалістичності грошей можна знайти а притчі про податок для кесаря: “Тож віддайте кесареве кесареві, а Богові Боже” (Мт 22:21). Запропонована [9] ідея дуалізму грошей грунтується на двоїстій природі товару - сонячній енергії та людській праці і полягає відповідно у двох проявах справедливості енергетичної та соціальної.

Енергетична справедливість полягає у рівному праві на накопичену перетворювану енергію, а соціальна справедливість полягає у праві споживача на ту частину річного багатства, на яку затрачено стільки людської праці, скільки споживач витратив на суспільство. Реалізувати такий розподіл можна кількома способами [9]. Один з них дуальні гроші.

Вихід з парадоксу в притчі динарій полягає в розділенні аверсу i реверсу, тобто в дуальних грошах. Якщо в одній кишені “ми носимо у гаманцях мішки із зерном" [2, с. 297], то в іншій маємо носити у солянках сіль із висохлого поту чола від нашої праці.

Висновки. Сформульована економічна парадигма, яка грунтується, на таких концепціях:

- фізична праця може мати переважно енергетичний або імпульсний характер;

- вартість має енергетичну та трудову складову;

- дуальні гроші як мірила вартості;

- роль капіталу прирівнюється до простих механізмів.

\section{Список використаних джерел}


1. LaRouche L. The Science of Physical Economy as the Platonic Epistemological Basis for All Branches of Human Knowledge // Executive Intelligence Review. -2018.-Vol. 45, №48.-P. 30-66.

2. Руденко M. Енергія прогресу. Нариси з фізичної економії. Видання друге, доповнене. - Тернопіль: Джура, 2005. - 412c.

3. Чернавский Д.С., Старков Н.И., Малков С.Ю., Косе Ю.В, Щербаков А.В. Об эконофизике и ее месте в современной теоретической экономике // УФН. -2011. -Т. 181, N 7.-С. 767-773.

4. Подолинський С.А. Вибрані твори / Упоряд.: Л.Я.Корнійчук. К.:КНЕУ, 2000.- 328c.

5. Воробйова Л.В. Енергетична теорія Сергія Подолинського і фізична економіка Ліндона Ларуша // Фізична економія: методологія дослідження та глобальна місія України: зб. матеріалів Міжнар. наук. конф., 8-10 квіт. 2009 р., м. Київ.-К.: КНЕУ, 2009.-С. 122-132.

6. Максимюк B.A. Природа фізичної економії як науки // Фізична економія у вимірах теорії і практики господарювання: колективна монографія / За ред. Ю.О. Лупенка, В.М. Жука, В.О. Шевчука та О.В. Ходаківської. -К.: ННЦ “Інститут аграрної економіки”, 2013.C. $27-50$.

7. Шевчук B.O. Контроль господарських систем в суспільстві 3 перехідною економікою (Проблеми теорії, організації, методології): Монографія. - К.: Київ. держ. торг. - екон. ун-т, 1998. - 371с.

8. Сагомонян А.Я. Проникание. - М.: Изд-во МГУ, 1974. - 299 с.

9. Максимюк B.A. Дуалізм у фізичній економії // Фізична економія: методологія дослідження та глобальна місія України: зб. матеріалів Міжнар. наук. конф., 8-10 квіт. 2009 р., м. Київ.-К.: КНЕУ, 2009.-С. 244-253. 
Мельник T.M.,

д. е. н., проф., Київський національний торговельно- економічний університет

Кудирко Л.П.

к. е. н., проф., Київський національний торговельно- економічний університет

\section{РЕНЕСАНС ПАРАДИГМИ ПРОТЕКЦІОНІЗМУ В СТРАТЕГІЯХ ІМПОРТОЗАМІЩЕННЯ}

Проблематика відродження протекціоністських засад сучасного макрорегулювання через імпортозаміщення в теоретичних та прикладних дослідженнях знаходить своє відображення в кількох аспектах: по-перше, мова йде про розробку альтернативних стратегій економічного розвитку для країн, що були глибоко інтегровані в систему міжнародного поділу праці та наразі перебувають під санкціями з боку країн світової спільноти (РФ, Венесуела); по-друге, в умовах посилення новітнього глобального суспільного тренду на непротекціоністські заходи захисту національного виробника та подолання ризиків високого рівня імпортозалежності національного виробництва та споживання (США, КНР); по-трете, створення умов для модернізації зовнішньоекономічної стратегії держави із посиленням акцентів на внутрішніх рушіях та джерелах економічного зростання (КНР).

Ідентифікація проблем та перспектив подолання імпортозалежності економіки України також мають багатовимірний формат та акцентують увагу на детермінантах подолання імпортозалежності економіки України та формуванні пріоритетів селективного імпортозаміщення[1], проблематиці залучення та використання іноземних інвестицій в економіку України в контексті їх впливу на секторальну структуру виробництва та зовнішнього сектору[2], дослідженні передумов інтеграції промисловості України до глобальних ланцюгів створення вартості на основі реалізації переваг у міжнародному поділі праці, у тому числі у форматі контрактних відносин[3], дослідженні напрямів трансформації зовнішньої торгівлі України в умовах геополітичних зрушень та визначенні методологічних засад іiі оптимізації[4] тощо. Зазначені напрацювання потребують подальшої актуалізації у контексті вирішення завдань забезпечення розвитку України в умовах неоіндустріальних змін, а 
саме - формуванні комплексного підходу до реалізації потенціалу імпортозаміщення країни шляхом оптимізації секторальної структури національного виробництва за рахунок його техносферизації, інформатизації та інтелектуалізації. Варто вказати також на низку дійсно цікавих досліджень, які презентують довготривалі напрацювання з питань реалізації стратегії імпортозаміщення на мікрота макрорівнях Зокрема мова йде про дослідження Дж. К. Хеллейнера, Д. Елвіна, М.Тодаро та інших.

Впровадження стратегії імпортозаміщення в сучасну добу, не зважаючи на вихідні передумови переходу до неї, наштовхується на цілу низку протидіючих чинників. Зокрема мова йде про - обмеження національних можливостей щодо технологій, які б стали альтернативою іноземним та які можуть бути впроваджені в національне виробництво; - підвищення витрат за міжнародні закупівлі товарів критичного імпорту у випадку переорієнтації їх із країн, що запроваджують санкції на користь держав із гіршими параметрами закупівель за критерієм «ціна - якість»; - вимивання фінансового ресурсу розвитку національного виробництва шляхом усунення компаній країни від міжнародних каналів та джерел інвестування та кредитування. В цьому контексті підтвердженням є результати реалізації стратегії імпортозаміщення в умовах дії санкцій щодо РФ. Самі російські експерти вказують на селективний характер успішності стратегії. Найбільший ефект набули в своєму розвитку низько - та середньотехнологічні галузі та сектори економіки (АПК, частково металургія та машинобудування). В той же час як у орієнтованих на науку високотехнологічних галузях імпортозаміщення так i залишилося на етапі декларації планів. За результатами емпіричних досліджень в Росії[5] в кількісному відношенні рівень затребуваного імпорту в російську промисловість порівняно незначний відповідних показників по країнах ЄС. Якщо ж виявляти, по яким саме групам імпорту спостерігається найвищий рівень імпортозалежності, то мова йде про машини і устаткування. I головна причина цього криється у відсутності аналогів продуктів, технологій і послуг на внутрішньому ринку, а в разі їх наявності - в низькому якості цільових пропозицій і його невідповідності технологічним параметрам замовлення. У цілому більш високий рівень імпортозалежності властивий все таки для високотехнологічних компаній, відповідно їх вразливість у випадку обмежувальних заходів щодо конкретних імпортерів, що підпадають під санкції може стати критичною. Російський досвід також засвідчує, що коли імпортозаміщення має здебільшого вертикальний характер та орієнтоване на відновлення ланок, що бракувало національній 
відтворювальній системі, воно приречене на слабку результативність. Це зумовлює впровадження заходів горизонтального рівня, зокрема у частині фінансування та створення окремих критичних технологій, формування нових галузей знань i принципово нових наукових компетенцій.

Стратегія імпортозаміщення в КНР, як зазначалось вище, може розглядатися як складова нової парадигми розвитку китайської економіки, що виникла на тлі нових реалій глобального економічного розвитку у посткризовий період (після світової фінансової кризи 20082009 років). Мова йде про так звану «нову нормальність», яку необхідно враховувати при формуванні стратегії розвитку КНР на середньостроковий та довгостроковий періоди. Під «новою нормальністю» розуміється стан розвитку світової та китайської економіки, який є наслідком розвитку глобальних кризових явищ у всіх важливих секторах та сферах та який унеможливлює повернення до докризових механізмів глобального та національного економічного розвитку. Для КНР це означає неможливість повернення до рекордних надвисоких показників економічного зростання, подальшого нарощування зовнішньої експансії на шкоду внутрішньому споживанню та реалізації, посилення асиметрії у частині накопичення підприємств корпоративного та державного секторів економіки. 3 2014 року це розуміння нових реалій стало втіленням нової стратегії економічного розвитку.

Хоча економічна трансформація КНР в окресленому напрямі ще далека від завершення, досягнутий прогрес останніх років у напрямку зниження рівня імпортозалежності, посилення частки національного виробництва в ланцюгах створення доданої вартості, структурних трансформаціях економіки та споживання $є$ дійсно вражаючим. Так, зокрема п’ять останніх років поспіль із КНР перебазувалися трудомісткі експортні галузі в менш розвинені країни з більш низькою вартістю праці. Регуляторна політика уряду КНР спрямовує бізнес до переходу на капіталомісткі форми національного виробництва як у сфері реального сектору, так і сфері послуг.

Ще одним важливим результатом окресленої політики $\epsilon$ те, що національний економічний розвиток стає менш залежним від зовнішніх ринків. Розміри внутрішнього ринку країни стрімко зростають: експерти очікують, що за кілька найближчих років він може стати найбільшим в світі. А оскільки китайський уряд має можливість контролювати доступ до цього ринку, його вплив в Азії і за їі межами буде також зростати. Ослаблення залежності КНР від зростання 
економіки за рахунок експорту позбавляє від тиску з боку стратегічних партнерів, які впливають на ії доступ до глобальних ринків.

Узагальнення теоретичних та емпіричних аспектів активізації непротекціоністської парадигми через стратегії імпортозаміщення в реалізації окремих держав засвідчує різновекторність іiі результативності. До основних обмежувальних факторів, що здійснюють деструктивний вплив на успішність стратегії імпортозаміщення $є$ обмеження національних можливостей щодо технологій, які б стали альтернативою іноземним та які можуть бути впроваджені в національне виробництво; підвищення витрат за міжнародні закупівлі товарів критичного імпорту у випадку переорієнтації їх із країн, що запроваджують санкції на користь держав із гіршими параметрами закупівель за критерієм «ціна - якість»; вимивання фінансового ресурсу розвитку національного виробництва шляхом усунення компаній країни від міжнародних каналів та джерел інвестування та кредитування. Ця стратегія на своїм змістом $\epsilon$ альтернативою сучасному тренду «розумної спеціалізації», цієї відносно нової концепції, що набуває все більшого визнання та поєднує теорії розподілу праці та міжнародної торговельної спеціалізації, агломераційної та еволюційної економіки [6]. В умовах посилення глобалізаційних процесів, ускладнення умов та джерел формування національної та глобальної доданої вартості ставка на імпортозаміщення як ефективну стратегію національного економічного розвитку XXI сторіччя викликає більше заперечень, ніж схвалення.

\section{Список використаних джерел}

1. Пугачевська К.С. Імпортозалежність внутрішнього ринку України / К.С. Пугачевська // Зовнішня торгівля: економіка, фінанси, право. - 2016. - №5. - С.27-40

2. Мельник Т.М., Касянок К.Г. Проблеми залучення та використання іноземних інвестицій в економіці України Україна // Маркетинг і менеджмент інновацій. — 2017. — №1 Режим доступу: http://mmi.fem.sumdu.edu.ua/journals/2017/1/253

3. Kudyrko L. Features of Ukraine participation in international contractual relations / T.Melnyk, L.Kudyrko, L.Samsonova// Baltic Journal of Economic Studies, Volume 4 Number 1. Riga: Publishing House "Baltija Publishing”, 2018, 372 pages.(Р.276-282) Режим доступу: http://baltijapublishing.lv/index.php/issue/article/view/361

4. Калюжна Н.Г. Підхід до визначення гравітаційних чинників впливу на зовнішньоторговельні відносини країн / Н.Г. Калюжна // 
Проблеми економіки. - 2017. - №1. - С. 26-31. http://www.problecon.com/export_pdf/problems-of-economy-2017-1_0pages-26 31.pdf

5. Simachev Y., Kuzyk M., Zudin N. (2016) Import Dependence and Its Substitution in the Russian Manufacturing: Business Viewpoint//Foresight and STI Governance, vol. 10, no 4, PP. 25-45.

6. EUA (2018) Coherent Policies for Europe Beyond 2020: Maximising the Effectiveness of Smart Specialisation Strategies for Regional Development. Brussels: European University Association. Режим доступа: https://eua.eu/component/attachments/attachments. html?id=376

Москаленко O.M., д.е.н., проф., ДВНЗ «КНЕУ імені Вадима Гетьмана»

\section{МІЖДИСЦИПЛІНАРНІСТЬ У СУЧАСНІЙ ЕКОНОМІЧНІЙ ТЕОРІЇ: ЧОМУ ЕКОНОМІСТИ ВИХОДЯТЬ ЗА ГЕДОНІСТИЧНІ ІНТЕРПРЕТАЦЇ̈ ПОВЕДІНКИ?}

Сучасна фундаментальна економічна наука розвивається в методологічних межах міждисциплінарного підходу, що стає ключовим трендом глобальної науки на принципах революції 4.0. Ускладнені процеси суспільного життя безпосередньо впливають на траєкторію розвитку науки, напрями і характер наукових досліджень, ïх диверсифікацію і перетин, та, разом 3 тим, вимагають від неї вирішення стратегічних суспільних завдань людиноцентричності, трансгуманітарності, а отже, утвердження позагедоністичних цінностей.

Сучасні альтернативні напрями теоретичної економічної науки, які стоять в опозиції, такі як поведінкова економіка (behavior economics), нейроекономіка (nеuroeconomics) i/або підтримують холізм і схильність до гедонізму індуктивної неокласичної економічної теорії, зокрема експериментальна економіка (ехрегіmental есопотісs), теорія ігор (game theory), управлінська економіка (таnagerial economics) назвати формами ефективного забезпечення реалізації 
людиноцентричної парадигми економічного розвитку навряд чи можна. Однак ці нові напрями економічної теорії по-іншому розглядають людину, виділяють іiі особливості психофізіологічного характеру, а значить вивчають емоції, оцінюють схильність до ризику, почуття від володіння і втрати грошей, намагаються оцінити рівень відчуття щастя і негараздів, а отже, тим самим ставлять іiі в центр уваги економічної науки з метою «покращення точності прогнозів». Людина стає гуманістичним суб'єктом, де важливою є «точка відліку», а не раціональне прагнення корисності. Людина постає в центрі уваги економіки, а не опосередковано отримує від загальної економічної політики «зміст очікувань типового індивіда» за умови нормального ведення справ, або скориговану «нічним сторожем» економічну політику у разі відхилення «від нормального ходу справ», що реалізує таку політику.

Гедоністичні побудови мейнстріму на основі неокласичного функціонально-факторного методу, залишаючись домінуючими, усе частіше піддаються конструктивній критиці, що дало поштовх для розвитку альтернативних економічних теорій на стику інших наук. Гетеродоксальні економісти приходять до висновку, що неокласична економічна наука майже нічого не знає про людину, тим самим пропонуючи нову альтернативу - плюралістичну економіку (pluralist economics). Методологічний індивідуалізм, раціональність, загальна і часткова рівновага, не заперечуються, а визнаються певною мірою практичними.

Як результат омріяних бажань та сміливих ідей поведінкових економістів, так звана «удосконалена версія економічної теорії» «поведінкова економіка», зайняла своє належне місце. Річард Талер про поведінкову економіку: «Вона [поведінкова економіка] не $є$ окремою дисципліною: це все ще економіка, однак збагачена знаннями iз психології та інших суспільних наук» [3, с. 26].

Так, поведінкова економіка не відмовляється від практичної функції моделі економічної людини, а визнає доцільність їі існування. «Від теорій, які засновані на припущенні, що кожна людина - екон, не потрібно повністю відмовлятися. Вони ще послужать нам вихідними точками для реалістичних моделей. А в окремих випадках, коли проблеми, 3 якими зіштовхується людина, легко розв'язати або суб'єкти економічної системи мають відповідні вузькоспеціалізовані професійні навички, моделі поведінки еконів можуть доволі адекватно відобразити те, що відбувається в реальному світі» [3, С. 26-27]. Проте, за твердженням поведінкових економістів, такі ситуації - радше виняток, ніж правило. Звідси випливають принципи державної 
політики в поведінковій економіці. Так, наприклад, один із засновників експериментальної економіки Вернон Сміт, який отримав Нобелівську премію в один рік з Деніелем Канеманом, протягом довгих років вважав, що експерименти у сфері економіки, підтверджують, а не спростовують, принципи раціональної поведінки. Це саме стосується і mеорії ігор, де суб'єкти в рамках теоретичної економіко-гедоністичної гри визнаються такими, що мають раціональний тип поведінки. Хто ж правий у суперечці про людську раціональність? Той факт, що і прихильник і опонент раціональної поведінки розділили між собою в 2002 році Нобелівську премію, свідчить швидше про те, що правильної і однозначної відповіді на це питання поки що не існує.

Проблему раціональності піднімає молода міждисциплінарна наука - нейроекономіка, яка, на жаль, в Україні ще не існує. Однак, на наш погляд, нейроекономіка, яка зародилася як нейронаука прийняття рішень (досліджує нейрологічний рівень прийняття рішень; провідні структури: Компанія Decode; Каліфорнійський технологічний інститут), у кінцевому рахунку змінить існуючі усталені уявлення про управлінську науку прийняття рішень. За висновками нейроекономістів, нераціональна поведінка, тобто поведінка, що не вкладається в традиційні нормативні економічні теорії, є результатом еволюційного відбору, закріпленого в структурі та функціях нейрональних мереж нашого мозку. Виходячи із сучасних уявлень нейроекономіки, прийняття рішень i, як наслідок, - вибір оптимальної поведінки відбуваються на рівні спеціалізованих нейронних мереж. У цілому нейроекономічний підхід $\epsilon$ відносно механістичним: нейронні мережі мають здатність регулювати оцінку всіх «за» і «проти» при виборі тієї чи іншої поведінки. Відповідно до цього підходу, нейрон, або нейронна мережа, яка приймає рішення, акумулює інформацію про можливі поведінкові альтернативи і робить вибір на користь найбільш оптимальної [2, С. 19-20].

Нейроекономіка має міждисциплінарний перетин 3 методом гіпотетичного вибору поведінкової економіки. Наприклад [5]:

\section{Проблема 1 - Азійська хвороба.}

Уявіть, що США приготувалися до спалаху незвичної Азійської хвороби, яка, як очікується, вб'є 600 людей. Запропоновані дві альтернативні програми для боротьби з хворобою.

Якщо програма А буде прийнята, 200 людей будуть врятовані.

Якщо програма В буде прийнята, то існує ймовірність 1/3, що 600 людей будуть врятовані і ймовірність $2 / 3$, що люди не будуть врятовані. Якій з двох програм Ви віддасте перевагу? 
Якщо програма A' буде прийнята, то 400 людей помруть.

Якщо програма В' буде прийнята, існує ймовірність $1 / 3$, що ніхто не помре і ймовірність 2/3, що помруть 600 людей.

Важливо, що поведінкова економіка має свою модель людини гуманістична людина, «гуман», на противагу раціональному суб'єкту, «екону». Річард Талер використовує поняття “екон” для позначення неокласичної моделі homo economicus, та термін "гуман” для позначення людини нераціональної, гуманістичної, вторгаючись у сферу психології тобто, можна назвати цю модель homo humanicus .

У неоліберальній неокласичній політиці, типове рішення державної політики $€$ абстрактним, емоційно знебарвленим. Наприклад, при прийнятті рішення про фінансування лікування ракових хворих приймаються рішення типу, скільки середньостатистичних життів урятувати. У неокласичній економіці «суспільство не платило би більше, щоб зберегти одне «ідентифіковане життя» замість двадцяти «статистичних». Поведінкова економіка поіншому розглядає державну політику. Наприклад, рішення приймаються, виходячи із подібних запитань, які сформульовані нами на основі принципів поведінкової економіки: «Скільки громадянин готовий заплатити, щоб вилікуватися від раку?», «Скільки ви готові заплатити, щоб проводити профілактичні щорічні огляди у онколога, 3 метою недопущення захворювання на рак або виявлення його на ранніх стадіях?», та «скільки громадянин готовий заплатити, щоб зменшити свій ризик захворювання на рак у 10 разів?», «Якою на вашу думку має бути сума фінансування ракових хворих, ураховуючи що ви - платник податків?». Тобто, методом прийняття державних рішень $\epsilon$ персоніфікований підхід, через розгляд ситуацій, у яких «люди зіштовхуються з проблемою компромісного вибору між грошима $\mathrm{i}$ ризиком смерті». Хоча гедоністичний підхід тут все ж таки зберігається; також такий підхід використовується при розрахунках заробітних плат для різних професій (видів робіт) з високим ризиком смертності.

Отже, міждисциплінарний підхід «пом'якшує» дисциплінарні кордони інших наук, дозволяє використовувати їх методологічні та інструментальні можливості, потенціал, аналізувати дані ( у т.ч. Big Data характерні для складних соціально-економічних і політичних систем), глибинні причини, умови, чинники, що знаходяться на стику досліджуваних областей (сфер), робити міждисциплінарні теоретичні 
узагальнення, синтезувати міжпредметні результати, робити адекватніші прогнози та передбачення щодо розвитку систем.

Однією з методологічних засад теорії ігор є егоїзм гравців, однак навіть і ця теорія виходять за гедоністичні межі. Парні категорії справедливо-несправедливо у грі «Ультиматум» у проведених лабораторних експериментах вказують на те, що людській поведінці притаманне неприйняття несправедливих пропозицій 70:30 у більш ніж половині випадків, при цьому гравець, що відмовився від несправедливого поділу не отримує нічого. При цьому в лабораторних експериментах люди часто пропонують справедливий 50:50 поділ [1, C. 72-73].

Не дивлячись на те, що теорію ігор критикують за використання спрощених теоретико-ігрових моделей соціальних взаємовідносин, оскільки вони не враховують такі поняття, як влада, ввічливість, громадянський борг, чесність, справедливість, репутація, власність тощо, теоретики, зокрема Кен Бінмор, спростовують такі звинувачення таким чином: «Напроти, ми вважаємо, що такі поняття - це феномени, які виникають, коли люди починають осмислювати рівноваги, в яких вони опиняються, граючи в гру життя» [1, С. 118].

У теорії ігор розрізняється раціоналістична та еволюційна інтерпретація рівноваги у випадку досконалої в субіграх рівноваги. Наприклад, у міні-грі «Ультиматум» філантроп надає гравцю 1 для поділу 8 доларів, і він може зробити гравцю 2 справедливу або несправедливу пропозицію. Дерево та матриця цієї гри зображені на рис. 1.

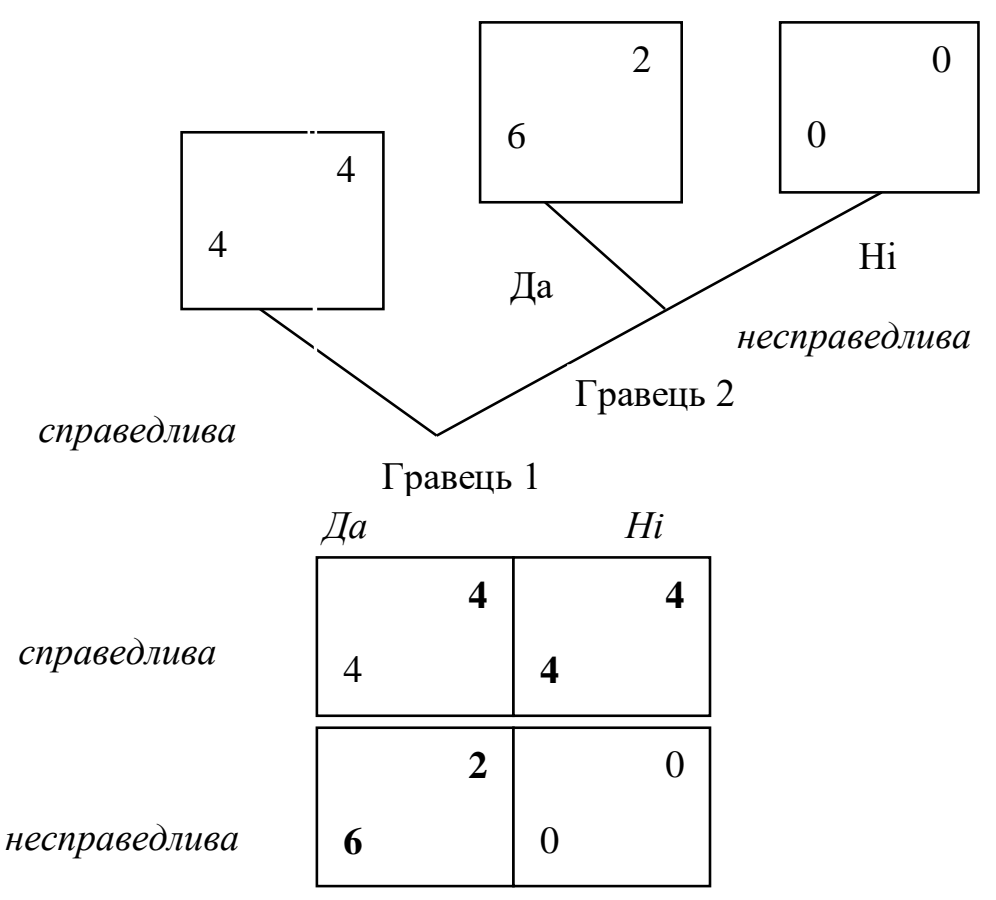




\section{Рис. 1. Міні-гра «Ультиматум». Дерево і матриця}

Примітка. Побудовано за [1, С. 75].

Міні-гра «Ультиматум» має єдину в субіграх рівновагу (несправедлива, да), що є змішаною стратегією другого гравця. Другою рівновагою за Нешем також буде (справедлива, ні). Немає причин передбачати, що в підіграх еволюційний процес зійдеться до досягнення досконалої рівноваги. Оскільки гравці навчаються методом проб і помилок, в яку рівновагу їм потрібно грати, то вони можуть починати грати в будь-яку рівновагу за Нешем. Висновки з міні-гри «Ультиматум»- це наявність різних еволюційних процесів [1, С. 7677].

Те саме доводять i нейроекономісти про справедливість: поперше, ймовірно, здатність оцінювати справедливість соціальної взаємодії надзвичайно важлива для забезпечення довгострокової кооперації всередині соціальної групи; по-друге, негайне мимовільне підкріплення справедливих пропозицій і покарання за несправедливе поводження - це важливий еволюційний механізм існування i згуртування соціальних груп [5]. Тобто, нейроекономісти заперечують висновки утилітарної теорії прийняття рішень (utility theory of decision making), яка майже повністю ігнорує вплив емоцій на прийняття рішень. Утилітарна теорія визнає суб'єкта прийняття рішень як «досконало раціональну когнітивну машину» [4, p. 1755].

Коли в «Дилемі в'язня» гравці починають грати чесно, тиск процесу еволюції одразу починає змінювати їх поведінку, оскільки єдиною рівновагою за Нешем є повна відсутність співробітництва між гравцями. Аналіз «Дилеми в'язня» показує, що співробітництво не обов'язково повинно бути раціональним [1, С. 77, 104].

Таким чином, міждисциплінарність притаманна економічній науці апріорі, з тим як вона виникла із філософії, класичної політичної економії, і з ними не втратила зв'язок. Окрім того, в межах економічної науки можна виділити існування внутрішньої міждисциплінарності, яка, на нашу думку, є співробітництвом фундаментальної і прикладних економічних наук між собою, різних економічних шкіл і течій між собою.

Наголосимо, що міждисииплінарний підхід в науці, економічній науці зокрема, має грунтовний потенціал і практичність системного бачення фундаментальних причин явищ, процесів, взаємодій та взаємовпливів суб'єктів і об'єктів досліджень та дійсності [6]. Отже, міждисциплінарний підхід усе далі буде розсувати і розмивати стовпи гедонізму в економічних теоріях, інкорпоруючи в них емоції, поведінкові реакції, феномени (за ортодоксальним підходом), 
нейробіологічні механізми прийняття рішень на рівні людини i формування суспільної та економічної політик.

\section{Список використаних джерел}

1. Бинмор, Кен. Теория игр : очень краткое введение / Кен Бинмор; пер. с англ. М.Л. Фреера и Е.С. Басовой; под науч. ред. М.И. Левина и В.П. Бусыгина. - М. : Издательский дом «Дело» РАНХиГС, 2017. - 256 с. - (Очень краткое введение).

2. Ключарев B. A. Нейроэкономика: нейробиология принятия решений / Ключарев В. А., Шмидс А., Шестакова А.Н. // Экспериментальная психология. - 2011. - Том 4. - № 2. - С. 14-35.

3. Талер Річард. Поведінкова економіка. Як емоції впливають на економічні рішення / пер. с англ. Світлана Крикуненко. - К.: Наш формат, 2018. - $464 \mathrm{c}$.

4. Alan G. Sanfey, James K. Rilling, Jessica A. Aronson, Leigh E. Nystrom, Jonathan D. Cohen. The Neural Basis of Economic DecisionMaking in the Ultimatum Game Science 300, 1755 (2003); DOI: 10.1126/science. 1082976.

Retrieved from: http://web.missouri.edu/ segerti/2210/Sanfey.pdf.

5. Klucharev, Vasily. Introduction to Neuroeconomics: How the Brain Makes Decisions: Course at Coursera by National Research University Higher School of Economics Retrieved from: https://www.coursera.org/learn/neuroeconomics/lecture/.

6. How do we evaluate interdisciplinary research? Published on Science Nordic . - 20.12.2013. Retrieved from: http://sciencenordic.com/how-do-we-evaluate-interdisciplinary-research.

Ніколаєць К. М.,

д. іст. н., професор, Київський національний торговельно-економічного університет

\section{ПЕРСПЕКТИВИ РОЗВИТКУ ФУТУРОЛОГІЧНИХ ДОСЛІДЖЕНЬ НА ПОЧАТКУ ХХІ СТ.}


У сучасних умовах спостерігається відхід футурології від створення глобальних проектів майбутнього існування людства із одночасним переходом до розробки конкретних питань і прогнозів у певних сферах життєдіяльності людини. Такий перехід, найбільш ймовірно, вмотивований складністю створення достовірних прогнозів на порівняно далеке майбутнє i необхідністю зосередитися на визначенні проблем, що найбільше хвилюють провідні країни світу чи регіональних лідерів на порівняно коротку перспективу. Дослідження у сфері футурології поділилися на теоретичні розмірковування про можливі варіанти майбутнього та прикладні наукові пошуки, чиє спрямування обумовлене потребами державних органів або великих виробників.

Розробкою футурологічних прогнозів займалися В.Занг, Р.Кроновер, Г.Ніколіс, Н.Рубіні, Е.Петерс, Е.Тоффлер, Ф.Фукуяма, С.Хангтінгтон, Р.Хансен.

Прикладний напрям футурології знайшов своє відображення у реалізації прогностичної функції багатьох суспільних наук. Реалізація такої функції вилилася у науково-технічне, природознавче та суспільствознавче прогнозування. Задля підвищення наукового рівня футурологічних прогнозів постійно вдосконалювався методичний інструментарій наукових пошуків. Таке вдосконалення було зумовлене специфікою використання науки. Тривалий час наука використовувалася людством переважно у якості джерела новітніх технологій. Більшість цих технологій використовували для модернізації військової техніки, а вже згодом нововведення були реалізовані у сфері виробництва цивільної продукції.

Ситуація змінилася у другій половині XX ст., коли модернізація зброї масового знищення призвела до появи засобів ураження, здатних знищити планету. Саме у той час у рамках футурології постали наукові дослідження прикладного характеру, спрямовані на прогнозування політичних дій, які могли б призвести до фатальних наслідків для усього людства. Водночас розвиток техніки суттєво вплинув на характер економічної діяльності. В умовах формування та розвитку інформаційного суспільства постала так звана інноваційна економіка, а темпи змін характеру економічних відносин, способів налагодження виробництва зросли до раніше нечуваних масштабів. Це обумовило актуалізацію футурологічних досліджень, спрямованих на прогнозування перспективної економічної діяльності 3 метою оптимізації інвестування. Тому футурологічне знання від літературного прогнозування поступово еволюціонувало у бік так званих «фабрик думок» із широким використанням перехресного 
експертного опитування. Набуло поширення використання методу моделювання можливих сценаріїв розвитку подій та стратегічного імітаційного моделювання, орієнтованого на дослідження поведінки суб'єктів у штучно змодельованих ситуаціях критичного вибору. Крім того, використовувався так званий метод форсайту, що передбачав багатоетапну роботу експертів.

Заміна індивідуальної роботи письменників-фантастів на роботу спеціалізованих творчих колективів зробила футурологічні розробки більш науковими. Водночас такі творчі колективи були переважно орієнтовані на вирішення конкретних завдань, що обумовлювало їх склад, характер роботи та ступінь наукової абстракції. Конкретність проблем обумовлювала порівняно низький рівень наукової абстракції у розумінні моделювання майбутнього на далекосяжну перспективу. Проте масштабне планування із прораховуванням багатоходових комбінацій широко використовували при розробці політичних комбінацій на міжнародній арені та у роботі спецслужб. Водночас зростання масштабів планування із збільшенням кількості фахівців груп, що використовували метод форсайту, призводило до нівелювання особистої складової авторів прогнозу. Це, у свою чергу, могло призвести до того, що більш раціональне рішення запропоноване конкретними дослідниками, могло бути відкинуте на користь вирішення проблеми, запропонованого колективом.

Крім того, поступово виявилися вади раціонального підходу при конструюванні майбутнього розвитку подій. Класичний раціональний підхід дозволяв аналізувати порівняно малі системи. А для аналізу великих систем із саморегуляцією та сталими зворотними зв'язками потрібно було використовувати методи, що дозволяли співвіднести знання про складну систему не лише із засобами операційної діяльності, а й із ціннісними орієнтаціями. Останнє обумовлювало необхідність аналізу нераціональної поведінки. Дієвість та необхідність такого аналізу була, наприклад, доведена Р.Талером[1].

Перед науковцями чітко постала проблема неможливості використання марксистської методології оцінки майбутнього як результату, що детермінований минулим та сьогоденням і має настати в силу дії об'єктивних законів. Непередбачуваність майбутнього, відсутність жорсткої детермінізації історичного процесу була чітко визначена К.Поппером[2]. Інноваційність історичного процесу, вплив на нього нераціональних дій та рішень зумовив розуміння принципової непередбачуваності майбутнього. Але інтереси та потреби провідних гравців на світовій політичній арені, потужних виробників вимагали пошуку ефективного інструментарію для прогнозування хоча б 
найближчого майбутнього. Водночас спрямованість форсайту на визначення вірогідності певного результату, бажаного для замовників, обмежувала коло наукового пошуку i, відповідно, методичний інструментарій. Наслідком стало поступове розуміння того, що майбутне формується сучасністю за зростаючого впливу нераціональних дій окремих суб'єктів. Тому при побудові форсайту не потрібно штучно ігнорувати низки суб'єктивних нашарувань, що виходять поза рамки інтересів замовника. У цьому зв'язку К.Майнцер стверджував, що перебуваючи у складно організованих системах, окремі особи діють в умовах обмеженої раціональності. Він наголошував, що керування складними процесами являє собою структурований процес, що враховує невизначеність, яка існує у реальному світі, а не ігнорує эï[3].

У сучасний період важливим видається використання синергетичного підходу для здійснення футурологічного аналізу економічних явищ та процесів. У роботах Е.Петерса[4], набуло поширення дослідження економіки за допомогою методів нелінійної динаміки. Власне так звану синергетичну економіку стали пов'язувати зі змінами у нелінійній економічній теорії[5]. Серед українських вчених у цьому контексті варто відзначити роботи В.Сергеєвої[6; 7]. Синергетичний підхід, побудований на можливості кооперації у складних системах, порівняно краще описує явища та події, що відбуваються в умовах глобалізації. Він може виявитися тією методологією, на основі якої можливе ефективне прогнозування. Проте кооперація не повинна тлумачитися чи використовуватися для штучної інкорпорації, забезпечення примусової інтеграції. Обумовлення необхідності вирішувати складні глобальні проблеми через кооперацію не повинне означати автоматичного розуміння необхідності нехтувати регіональними проблемами задля вирішення більш масштабних.

Свого часу один із ідеологів глобалізації З.Бжежинський стверджував, що сучасний світ відрізняється інтерактивністю та взаємозалежністю, і вперше у історії міжнародні конфлікти поблякли перед загальною проблемою виживання людства. Засобом вирішення глобальних проблем дослідник називав передусім геополітичну стабільність, але аналізував іï передусім 3 точки зору інтересів та потреб США в умовах зростання впливу Китаю і спроб Росії, Індії, Бразилії конкурувати один з одним за ресурси, безпеку та економічну перевагу[8, с.3]. Водночас у сучасних умовах, окрім загрози нового світового руйнівного протистояння, посилюється вПлив розвитку кіберпростору[9, с.177], який для частини населення планети $€$ 
своєрідним засобом відсторонення від оточуючих проблем, а для інших - основою економічної діяльності. Певний вплив на цей процес чинить і розбудова економічної діяльності в умовах зростаючих темпів урбанізації. На думку А.Росса, коли технологічна просунутість стає вимогою до муніципальних послуг, у найбільш виграшній позиції опиняються глобальні міста, які можуть розробляти для громадян додатки, які будуть приваблювати до мегаполісів клас «економіки майбутнього»[10, с. 225]. Тому новим викликом для футурології постає необхідність залучення для аналізу додаткового інструментарію, можливо із сфери психології чи педагогіки, 3 метою адекватних висновків щодо визначення перспектив співіснування світу людини $\mathrm{i}$ машинного середовища. Таке співіснування потребуватиме ще більш прискореного обміну даними i, на думку деяких дослідників, може навіть обумовити поділ людей на різні біологічні касти. Однак у XXI ст. постіндустріальна цивілізація, спираючись на штучний інтелект, біоінженерію й нанотехнології, може зробити непотрібними цілі країни і континенти. Самопроголошені «цивілізовані» зони у такому випадку отримають у своє розпорядження найновіші технології виробництва, а інші - будуть позбавлені подібних досягнень цивілізації[11, с.109].

Реальністю XXI ст. фактично стала необхідність широкого використання синергетичних досліджень у царині економіки. Технічні можливості, у тому числі передачі та обробки інформації, постали важливим чинником перспективних перетворень у сфері пошуку адекватних моделей наукового пошуку у царині футурології. Робота окремих «фабрик думок» чи використання методу форсайту вже не відповідають реаліям часу. Потрібна кооперація різнопланових дослідників з багатьох країн для ухвалення синтетичних рішень, які б визначали перспективи розвитку людства не лише у сфері виробництва, а мали б комплексний характер. Синергетичний підхід також може виступити засобом своєрідної демонополізації світового ринку, що забезпечить більш високі шанси для порівняно відсталих у економічному відношенні країн, але одночасно усуне для людства перспективу кривавого протистояння між багатими та бідними державами через перерозподіл джерел сировини.

\section{Список використаних джерел}

1. Талер Р. Поведінкова економіка. Як емоції впливають на економічні рішення. / пер. $з$ англ. С. Крикуненко. - Київ : Наш формат, 2018. - 464 c. 
2. Поппер К. Відкрите суспільство та його вороги. Т. І. У полоні Платонових чарів / Пер. 3 англ. Олександр Коваленко. - Київ : «Основи», 1994. - 444 с.; T. II. Спалах пророцтва: Гегель, Маркс та послідовники / Пер. 3 англ. Олександр Буценко. - Київ : «Основи», 1994. - $494 \mathrm{c}$.

3. Майнцер К. Вызовы сложности в XXI веке // Вопросы философии, 2010. - № 10. - С. 84-99.

4. Петерс Э. Хаос и порядок на рынках капитала / пер. с англ. Москва: Мир, 2000. - 333 с.

5. Занг В. Б. Синергетическая экономика. Время и перемены в нелинейной экономической теории / пер. с англ. Н. В. Островская. Москва: Мир, 1999. - 335 с.

6. Сергеева Л. Н. Моделирование поведения экономических систем методами нелинейной динамики (теории хаоса). - Запорожье: Запорож. гос. ун-т, 2002. -227 с.

7. Сергеева Л. Н. Нелинейная экономика: модели и методы.

Запорожье: Полиграф, 2003. - 217 с.

8. Бжежинский 3. Стратегический взгляд : Америка и глобальный кризис. - Москва: АСТ, 2013. - 285 с.

9. Форд, Мартін. Пришестя роботів. Техніка і загроза майбутнього безробіття. - Київ : Наш формат, 2016. - 400 с.

10. Росс А. Індустрії майбутнього / пер. $з$ англ. Н. Кошманенко. - Київ: Наш формат, 2017. - 320 c.

11. Харарі Ювал Ной. 21 урок для 21 століття / пер. 3 англ. О. Дем’янчука. - Київ: Форс Україна, 2018. - 416 с.

Ожелевська Т.С., к. е. н., доцент, Київський національний торговельноекономічний університет

\section{УКРАЇНСЬКИЙ МЕЙНСТРИМ ЕКОНОМІЧНОЇ ТЕОРЇ̈: РОЗВИТОК ЧИ ІНСТИТУЦЙНА ПАСТКА?}

Лауреати Нобелівської премії Д. Канеман та Р. Талер, а також А. Тверскі дослідженнями у галузі поведінкової економіки забили "останній цвях у гроб" неокласичної економічної теорії, обгрунтувавши повну неспроможність теорії раціонального вибору індивіду, яка є головним постулатом ортодоксальної економічної 
науки. Зрозуміло, що дослідження, які базуються на хибних вихідних даних, як правило, призводять до хибних висновків.

Недосконалість неокласичної теорії була виявлена ще на межі XIX-XX ст., коли вона не змогла пояснити наявний хаос в економіці та потужну кризу у 1929-1933 pр. Це призвело до зародження у 1920-1930 pp. нового напряму економічної думки - інституціональної економічної теорії, перші дослідники якого стверджували про міждисциплінарність економічної теорії, а також: "Уявлення про те, що єдине прагнення індивідів полягає у максимізації корисності, є неадекватним або помилковим. Інституціоналізм не розглядає індивідів як певну даність. На індивідів впливає інституційна і культурна ситуація, в якій вони знаходяться. Таким чином, індивіди не просто (навмисно чи ненавмисно) створюють інститути. За допомогою «зворотноього низхідного причинно-наслідкового зв'язку» інститути фундаментально впливають на індивідів" [1, p. 318].

До 1960-1970-их років єдиною мовою економічної науки була мова графіків та формул. Більше 200 років економічна теорія у своїх дослідженнях спиралася на модель "людини економічної" - "homo economicus" - егоїстичного, раціонально мислячого, максимізуючого свою вигоду суб'єкта. I хоча ця модель зручна для моделювання, але вона не відповідає поведінці людини, що робить вибір у реальному житті. Як дуже влучно висловився П. Вайс: "Теоретикисуспільствознавці наділили своїх модельних людей - homo economicus i homo sociologicus - такими здібностями, які дозволяють їм вижити лише в рівноважному світі, але не в світі нестабільності" [2, p. 148].

Модельний підхід до економічного аналізу докорінно змінився після доведення лауреатом Нобелівської премії Г. Саймоном теорії обмеженої раціональності, яка спростовувала фундаментальну аксіому класичної економічної теорії у моделі "економічної людини" ("hoто economicus"). Відповідно до теорії обмеженої раціональності людина не може вести себе раціонально і максимізувати корисність, оскільки має неповну інформацію, обмежені увагу та розумові здібності, щоб визначати оптимальні цілі та прораховувати довгострокові наслідки прийнятих рішень щодо раціонального розміщення обмежених ресурсів [3, p. 14]. Важливим кроком в обгрунтуванні хибності теорії раціонального вибору ортодоксальної економічної теорії стало виокремлення лауреатом Нобелівської премії О. Вільямсоном поняття опортуністичної поведінки індивіда, який під опортунізмом розумів «...досягнення своїх інтересів, в тому числі обманним шляхом, включаючи сюди такі явні форми обману, як брехня, злодійство, шахрайство, але навряд чи обмежуючись ними...» [4, p. 47]. Отже, при 
прийнятті рішень індивід може бути введений в оману іншим індивідом і прийняти неоптимальне рішення.

Прихильники ортодоксальної економічної теорії, яких на час формування інституціоналізму, була переважна більшість і які не змогли спростувати прикладної цінності одержаних результатів дослідження у новому напряму економічної науки, але й не хотіли поступатися мейнстримом, застосовували новітні розробки у неокласичній економічній науці. В результаті сформувалася неоінституціональна економічна теорія, яка виникнувши, як i традиційний інституціоналізм, для критики неокласичної ортодоксії, згодом сама стала фактично частиною неокласики, оскільки базувалася на передумовах неокласичної теорії i, перш за все, на методологічному індивідуалізмі.

Дослідження Д.Канемана та А.Тверскі знову повернули мейнстрим економічної теорії до теоретичних постулатів класичного ("старого") інституціоналізму, який доводить повну неспроможність ортодоксії. Вони описали експериментальні ситуації, у яких оцінки, зроблені індивідами враховуючи первинну інформацію, не переглядаються на стільки часто, як цього вимагається відповідно до теореми Баєса [5, с. 242]. У інших випадках суб'єкти реагують на найсвіжішу інформацію, а попередню не враховують належним чином. Отже, у більшості випадків поведінка людини дуже відхиляється від моделі "homo economicus".

Погоджуючись 3 прихильниками класичного інституціоналізму Дж. Ходжсоном та Д. Коландером, можна стверджувати, що сучасний світовий мейнстрим економічної теорії змінилася радикально. Неокласична парадигма, - включаючи іiі «ядрові» концепції раціональності та рівноваги, - вже не домінує в рамках мейнстриму економічної теорії, і замінена різномаїттям підходів. Ця теза була підтверджена інтерв'ю з аспірантами найпрестижніших економічних вишів, особливо в США [6, p. 11]. На думку Д. Коландера [7, p. 930931], мейнстрим економічної теорії відмовився від своєї «святої трійці» - передумов «раціональності, жадібності і рівноваги». Натомість, бачення економічної науки змінюється наступним чином: від «вивчення нескінченно прозорих агентів у інформаційно багатих середовищах до трактування економічної науки, що досліджує прозорих у певних межах індивідів у інформаційно бідних середовищах».

Не можна не погодитись з В.Д. Лагутіним, що "методологічна та евристична цінність інституційної теорії $\ldots . \in$ очевидною... Інституційний аналіз, зосереджуючись на механізмах функціонування 
і взаємодії інститутів, долає недоліки неокласичного підходу, який грунтується на однобічній методології індивідуалізму" [8, с. 38]. Але на відміну від кардинальної зміни напряму розвитку світової економічної думки український мейнстрим економічної теорії продовжує підтримувати на "апараті штучного дихання" ii ортодоксальний (неокласичний) напрямок у неймовірному поєднанні 3 вульгаризованим В. Леніним марксизмом. Така поведінка українських вчених вже пояснена Р. Талером: "Економісти мають свій усталений погляд на те, як усе має відбуватися, і опиратимуться змінам хоча б тому, що присвятили свої роки облаштуванню куточка в будинку економічних теорій" [9, с. 64]. Але невизнанання та небажання досліджувати українською науковою спільнотою сучасного світового мейнстриму економічної теорії свідчить про формування стійкої інституційної пастки, яку так важко протягом століття долала світова економічна теорія.

Вона проявляється, по-перше, у тотальному скороченні (а іноді взагалі вилученні) у навчальних планах 3ВО складових дисциплін економічної теорії. І це той час, як філіали великих світових компаній, беручи випускника українського вишу, тестують його на глибоке знання економічної теорії! Це відбувається через визнання українським суспільством відірваності українського мейнстриму економічної теорії від реальної економіки, а також через опортуністичну поведінку керівників випускових кафедр 3ВО, які більше піклуються не за якість випускників, а за педагогічне навантаження членів свого колективу. При цьому не відбувається впровадження у навчальний процес прикладних і вкрай важливих для формування економічного світогляду випускника дисциплін світового мейнстриму економічної теорії, зокрема "Інституціональна економіка", "Поведінкова економіка" тощо. У кращому випадку ці дисципліни ставлять у навчальні плани як вибіркові для магістрів. У деяких ЗВО дисципліни неокласичної економічної теорії можуть доповнюватися темами про суспільний вибір, трансакційні витрати, але дотримуючись загальної методології дослідження неокласичної економічної теорії.

По-друге, у суспільстві завдяки тривалому викладанню марксистсько-ленінської політичної економії та неокласичної економічної теорії, які не мали прикладного характеру, сформувалося стійке негативне ставлення суспільства до будь-якого напряму дослідження економічної теорії, що загрожує у майбутньому тотальною економічною неграмотністю населення, яке у свою чергу може призвести до політичних, економічних та соціальних катаклізмів в країні. 
По-третє, світовий тренд інституціоналізму та нерозуміння його глибоких підвалин українськими вченими (навіть дуже поважними і "титулованими") призводить до появи у більшості публікацій школярських помилок, які стосуються постулатів інституціоналізму. Так, відсутність глибокого розуміння підвалин інституціональної економічної теорії, наприклад відсутність знань 3 основ теорії інституціональних змін та ефекту "блокування" (path dependence), призвело до хибного, на нашу думку, твердження українського науковця В. П. Онищенко, а саме: "...на заваді будь-якого насилля стоїть конкуренція інститутів i, в кінцевому рахунку, в процесі еволюції перемагають найбільш конкурентні" [10, с. 130]. Використання у дослідженнях української економічної теорії та публікаціях окремих категорій та інструментів інституціоналізму без знання його парадигми призводить до розвитку псевдонауки з хибними науковими результатами, які ще більше посилюють негативне ставлення українського суспільства до економічної теорії.

По-четверте, блокування розвитку новітнього інституціоналізму та поведінкової економіки блокує економічний та політичний розвиток України, адже саме приріст знань забезпечує ідентифікацію можливості. У той час, коли при президентах США та Росії, а також при британському уряді працюють радниками інституціоналісти, що $\epsilon$ визнанням важливості та прикладного характеру інституціональної економічної теорії, українські можновладці навіть не знають про існування такої важливої для керівництва державою науки.

Досвід розвитку України демонструє, як універсальні методи неокласичної теорії при проведенні економічної політики, без урахування особливостей функціонування національної інституційної структури, призводять до руйнівних соціально-економічних наслідків. У зв'язку з цим не випадково сьогодні інституційна теорія стала однією 3 провідних економічних шкіл у світовій науці. I викликає занепокоєння, що в Україні до цього часу продовжує домінувати неокласична теорія.

\section{Список використаних джерел}

1. Hodgson Geoffrey M. What is the Essence of Institutional Economics? // Journal of Economic Issues. - 2000. - Vol. 34. - № 2. - P. 317-329.

2. Weise P. Homo economicus und homo sociologicus: Die Schreckensmänner der Socialwissenschaften // Zeitschrift für Sociologie. - April 1989. - Jg.18. - H.2. - S.148-161.

3. Simon H. A. Rationality as Process and as Product of Thought. Richard T.Ely Lecture [Електронний ресурс] // American Economic Review, 
May 1978. - V.68. - №.2. - Р.1-16. - Режим доступу: http://www.business.illinois.edu/josephm/BA504_Fall\%202008/Sessio n\%208/Simon\%20(1978).pdf

4. Williamson O. E.. Behavioral Assumptions. In: O.E.Williamson. The Economic Institutions of Capitalism. Firms, Markets, Relational Contracting. N.Y.: The Free Press, 1985. - P.44-52.

5. Kahneman D. and Tversky A. On the Psychology of Prediction [Електронний ресурс] // Psychological Review, July 1973. - V.80. P.237-251.

Режим доступу: http://citeseerx.ist.psu.edu/viewdoc/download?doi=10.1.1.395.3759\&re $\mathrm{p}=$ rep $1 \&$ type $=$ pdf

6. Hodgson G. M. Evolutionary and Institutional Economics as the New Mainstream? [Електронний ресурс] // Evolutionary and Institutional Economics Review. - 2007. - №4(1). - Р.7-25. - режим доступу: http://www.laisumedu.org/desin/fronteras/Hodgson.pdf.

7. Colander D.C. The Future of Economics: The Appropriately Educated in Pursuit of the Knowable [Електронний pecypc] // Cambridge Journal of Economics. - 2005. - № 29.6. - P. 927-941.

8. Лагутін В.Д. Можливості інституційного аналізу суспільної стабільності та розвитку [Електронний ресурс] / В.Д. Лагутін // Вісник КНТЕУ. - 2018. - № 3(119). - С. 37-52.

9. Талер Р. Поведінкова економіка. Як емоції впливають на економічні рішення / Ричард Талер / пер. $з$ англ. С. Крикуненко. - К.: Наш формат, 2018. - 464 c.

10. Онищенко В. Глобальне управління у контексті міжнародної політичної економіки [Електронний ресурс] / В. Онищенко // Вісник КНТЕУ. - 2018. - № 2(118). - С. 121-136. - Режим доступу: http://visnik.knteu.kiev.ua/files/2018/02/12.pdf.

Осецький В.Л., д.е.н., проф., Київський національний університет імені Тараса Шевченка

\section{ІМПЕРАТИВИ ОНОВЛЕННЯ МЕТОДОЛОГІЇ ЕКОНОМІЧНОЇ АНАЛІТИКИ}

Методологія не є проста сума окремих методів, їх "механічна єдність". Методологія - складна діалектична, цілісна, субординована 
система способів, прийомів, принципів різних рівнів, сфер дії, спрямованості, владних повноважень, змістів, структур і т.п. Змістовне розуміння методології виходить 3 того, що в ній реалізується пошукова функція предметної області дослідження. Будь-яка теоретична система знання має сенс лише остільки, оскільки вона не тільки описує i пояснює деяку предметну область, але одночасно є інструментом пошуку нового знання. Саме методологія визначає в якій мірі зібрані факти можуть служити реальним і надійним імперативом знання.

A. Гальчинськй, який $\epsilon$ одним із фундаторів оновлення економічної методології, зазначає, що «Методологія - це знання знань». За допомогою методології економічна наука заглиблюється сама в себе - визначає своє співвідношення з предметом дослідження, межі свого застосування, ідентифікує себе як суспільна наука, розкриває зв'язки 3 іншими науками, спосіб взаємодії знань зі знаннями, теорії та реальності й у цьому сенсі виступає як субдисципліна, основа економічної науки [1, с. 69].

Відомий англійський учений Марк Блауг у спеціальному дослідженні «Методологія економічної науки» (1992) наводить таке визначення: методологія - це складова економічної науки, що розглядає способи, за допомогою яких економісти обгрунтовують свої теорії. «Методологію економічної науки, - наголошує іменитий вчений, - варто розуміти просто за філософію науки в ії застосуванні до економіки» [2, с. 35]. Йдеться про те, що філософія в ії новітніх визначеннях виконує інструментальну функцію щодо економічної методології. Водночас економічна методологія виходить за науковопізнавальні межі й усе більшою мірою інтегрується безпосередньо у філософський простір.

Підтверджують це розуміння і представники сучасної аналітичної економіки Київського національного університету імені Тараса Шевченка В. Базилевич та В. Ільїн, зосереджуючись на визначенні методологічних засад новітніх економічних процесів, вказують: «Це обумовлено розширенням предметного поля економічного знання, що охоплює зараз не лише виробничо-господарські, але і філософські, духовні проблеми економічної науки. Це вже не сугубо економічна теорія, що фокусує увагу на змістовній стороні здійснювального пізнання. Вона включила в коло своїх інтересів не лише гносеологічну проблематику (аналіз основних сенсів економічного знання), але й онтологічну, пов'язану 3 метанауковими (філософськими, моральними, правовими та ін.) уявленнями про саму економічну реальність. Величезна роль у цьому плані належить метафізиці, що 
орієнтує на пізнання не тільки «феноменального», але й «ноуменального» світу, його сутності» [3, с. 97].

Власне мова йде про розширення поля пізнання економічної реальності за рахунок введення у економічну теорію нового пласту методологічних знань, бо самі економічні знання без пізнання i розкриття проблем онтологічного характеру значно збіднюють можливості економічної науки щодо створення наукової картини господарської реальності.

Все це вказує на необхідність методологічних оновлень як у сфері науки взагалі, так і в економічних дослідженнях. Якщо ж змінюється тренд вимог до наукового аналізу, його методів, то схематично, бездумно копіювати вже «заїзжені» теорії зовсім недостатньо. Особливо це актуалізується, коли спостерігаються «великі трудності» вітчизняної науки в поясненні та оцінці того, що відбувається в країні. Ми не маємо надійної теорії, що здатна пояснити нинішній стан українського суспільства, у нас немає необхідного для цього понятійно-категоріального апарату [4].

Оновлення методології економічних досліджень через розгортання антикризових трансформацій не зводиться лише до економічного, а включає в себе більш глибинні основи цінніснораціонального характеру. Перехід до мислення в форматі ціннісної, сутнісної раціональності постає життєво важливим як для самої науки, так і для інноваційних змін у соціальному організмі сучасного глобального соціуму. Саме в теоретичному заглибленні до рівня ціннісної раціональності сьогодні слід шукати імперативи розв'язання теперішніх найгостріших соціально-економічних проблем і протиріч, які до крайності загострили проблему «межі зростання»: «Сьогодні здатність людства діяти значно перевищила здатність розуміти. В результаті цього цивілізація зіткнулася з ідеальним штормом проблем, спричиненим перенаселенням, надмірним споживанням 3 боку багатих, використанням технологій, які завдають шкоди довкіллю, та безпрецедентною нерівністю [5, с. 1].

Методологія будь-якої науки, зокрема економічної, реалізує свої визначення не безпосередньо, а використовуючи для цього певну систему методів аналізу. Методологія відбиває принципи, а методи $є$ інструментами наукового аналізу. Універсальність принципів економічної методології має досить вагому аргументованість. Вона визначається специфічністю предмета економічної науки дослідженням економічних зв'язків, які не автономні за своїм змістом, а є складовими цілісної системи суспільних відносин, а отже і цілісної системи суспільних наук [6]. 
Інший аспект цієї проблеми: універсальні принципи, які використовує економічна методологія, жодною мірою не можуть сприйматися як система незмінних постулатів та алгоритмів. Кризові процеси в науці як невід'ємний атрибут іï розвитку насамперед відбивають невідповідність іiі універсальних методологічних основ новітнім умовам суспільної трансформації [1, с. 76].

Ця ситуація характерна для сучасної економічної теорії. Сформована на попередніх етапах суспільних трансформацій методологічна база економічної аналітики все більшою мірою девальвує свою нормативну функцію, набуває ознак не системності.

Отже, необхідно оновити методологію економічної теорії аби адаптувати їі до умов сучасного світового господарства. Недостатньо включити до теорії нові соціальні потреби, перевівши їх у грошовий еквівалент капіталу. Оновлення методології дослідження цілісної господарської людської діяльності в сучасному розвитку світового господарства, також має змінити імперативи, пріоритети та системи стимулів і цінностей для вивчення цілісної реальності Всесвіту.

\section{Список використаних джерел:}

1. Гальчинський А.С. Економічна методологія. Логіка оновлення: Курс лекцій. - К.: «АДЕФ - Україна», 2010. - 572 с.

2. Блауг М. Методология экономической науки. - 2-е изд. - М., 204. - c.35.

3. Базилевич В.Д. Метафизика экономики: возможности необходимого/В.Д. Базилевич, $\quad$ В.В. Ильин//Философия хозяйства, 2009, №6. - с. 97-103.

4. Задорожня О.Г. Сучасне господарство: постнекласична методологія як основа розгортання антикризових трансформацій: Монографія. - Харків: «Точка», 2018. - 356 с.

5. Ернст Ульріх фон Вайцзеккер, Андре Війкман. Come on! Капіталізм, недалекоглядність населення і руйнування планети. Доповідь Римському клубу/ Ернст Ульріх фон Вайцзеккер, Андре Війкман; переклад 3 англ. Ю. Сірош; за наук. ред. В. Вовка, В. Бутка. - К.: Саміт-Книга, 2013, - 276 с.

6. Маршалл А. Принципы политической экономии. - Т. 1 - с. 85. 
Петренко В. П., Д. е. н., професор Івано-Франківський національний технічний університет нафти і газу

\section{РОЛЬ І ЗАВДАННЯ ЕКОНОМІЧНОЇ НАУКИ У ТРАНСФОРМАЦЇ̈ ІНСТИТУЦІОАЛЬНОЇ МАТРИЦІ СУЧАСНОГО УКРАЇНСЬКОГО СУСПІЛЬСТВА}

Оскільки, сучасному стану інституціональної системи України є притаманним інституціональний вакуум та інституціональний хаос, в результаті чого замість інститутів ринкового типу сформовано квазіринок, замість конкуренції - монополія ті корупція, замість державного управління нового типу - патрон-клієнтелізм, на цілком обгрунтовану думку авторів [1] Україні необхідні «... такі зміни економіки, що зламають кланово-олігархічну систему публічного управління, усунуть із культурно-інституціонального простору держави патрон-клієнтелістські відносини та сурогатні інститути взаємодії між рівнями публічної влади, бізнесом і громадянським суспільством».

Автор дослідження [2] також прийшов до висновку, що «Чільне місце в інституціональній системі суспільства займає економічна підсистема - сукупність економічних інститутів», якими «...соціальна практика закріплює ті способи взаємодії господарюючих суб'єктів 3 конкретним матеріально-технологічним середовищем, що дозволяють отримувати оптимальний соціально-економічний результат».

Таким чином, роль економічної науки полягає в генеруванні і реалізації таких рекомендацій щодо пріоритетних змін в економіці, які можуть і повинні «зламати» та «усунути» існуючі перепони у формуванні і розвитку українського суспільства, а також «закріпити» отримані в цьому процесі результати.

При цьому, завдання вітчизняної економічної науки повинні визначатися потребами активної трансформації суспільства «редистрибутивної» економіки в «ринкову» $з$ деталізацією цих завдань як у сфері теоретичних знань, законів, гіпотез і концепцій, так і в методології пізнання нових економічних реалій, продукування нових знань і досвіду епохи інтелектуальної цифрової і т. п. економіки.

Окрім цього, дуже важливого значення в успішній трансформації українського суспільства набувають інституційне, інформаційне і кадрове забезпечення наукових досліджень в сфері економіки i публічного управління як однієї 3 базових підсистем тієї 
інституціональної матриці, до якої воно повинно прийти в результаті інституціональних змін в системі, в політиці та ідеології публічного управління.

Цілком очевидно, що сучасна вітчизняна економічна i управлінська наука не може і не повинна обмежитися ретрансляцією та адаптацією інституціональних теорій як Сходу, так і Заходу, оскільки вони не є адекватними реаліям пострадянської України та іï трансформаційним потребам. Нашому суспільству необхідна власна фундаментальна теорія, методологія і практика інституціональної перебудови, над чим уже успішно працюють вітчизняні науковці. Про це, для прикладу, свідчить ціла низка наукових розвідок щодо різноманітних економічних аспектів інституціональних

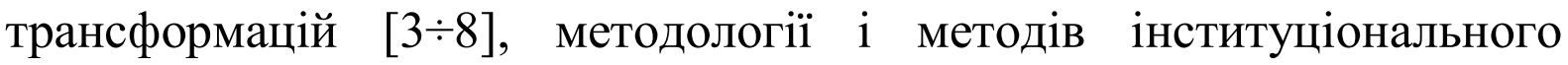
аналізу, змін, оцінки наслідків перетворень, виявлення недоліків

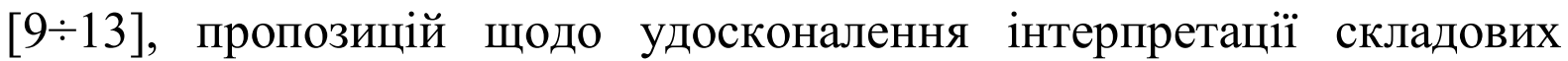
інституціональних матриць для умов перехідного періоду [3, 4, 14], ролі ментальності людських ресурсів в цих процесах [14].

Зауважимо, що важливою рисою всіх перерахованих розвідок $\epsilon$ визнання їх авторами факту єдино можливої форми економічного i соціального розвитку суспільства виключно у вигляді еволюційного поступу за провідної ролі системи публічного управління i адміністрування процесами переходу суспільства до ринкової економіки 3 можливістю обмеження іiі регуляторних впливів i належного трансформування ідеологічних i культурних цінностей людських ресурсів суспільства.

\section{Список використаних джерел}

1. Молодцов О. В. Деякі аспекти проблеми інституціональної синхронізації процесів децентралізації в Україні / О. В. Молодцов, О. В. Радченко. // Теорія та практика державного управління і місцевого самоврядування. - $2017 . \quad$ - № $1 . \quad$ доступу: http://nbuv.gov.ua/UJRN/Ttpdu_2017_1_10

2. Оболенський О. Ю. Інститути економічної системи суспільства як об'єкти публічного управління / О.Ю.Оболенський / О.Ю. Оболенський // Науковий вісник Академії муніципального управління. Серія : Економіка. - 2010. - Вип. 8. - С. 24-41.

3. Болотіна Є. В. Інституціональна структура перехідної економіки України / С. В. Болотіна // Науковий вісник Донецької державної машинобудівної академії. - 2012. - №1(9Е). - С. 243 - 249.

4. Болотіна Є. В. Інституціональні матриці суспільства та трансформаційна економіка України / Є. В. Болотіна, О. В. Шубна // Бізнес-Інформ. - 2016. - №10. - С. 14-21. 
5. Гражевская Н. И. Теоретико-методологические новации институционализма в исследовании экономических трансформаций / Н. И. Гражевская // Європейський вектор економічного розвитку: Зб. наук. праць. Вип. 2(13). - Дніпропетровськ: Ін-т ім. А. Нобеля, 2012. C.47-50.

6. Поченчук Г. М. Інституціональний вимір структурних характеристик економічної системи / Г. М. Поченчук // Економічна теорія та історія економічної думки. - 2017. - №6(62). - С. 25 - 32.

7. Чубарь О. Інститути та інституціональне середовище : теоретичні узагальнення засад економічного розвитку / О. Чубарь // Наук. вісн. Ужгород. ун-ту : зб. наук. пр. / ред. : В. Мікловда, М. Пітюлич, Н. Гапак та ін. - Ужгород : УжНУ, 2013. - Вип. 3(40). - С. 98-104.

8. Манцуров I. Інституційне планування в системі державного регулювання економіки : [монографія] / I. Манцуров. - Київ : НДЕІ, 2011. -655 c.

9. Лагутін В. Можливості інституційного аналізу суспільної стабільності та розвитку // Вісник КНТЕУ: науковий журнал, 2018. №3 (119). - С. 37- 52 .

10. Слагін В. П. Інституціональні перетворення як основа ефективного розвитку головних ресурсних сфер держави / В. П. Єлагін // Вісник Національного університету цивільного захисту України. Серія : Державне управління. - 2014. - Вип. 2. - С. 98-106. - Режим доступу: http://nbuv.gov.ua/UJRN/VNUCZUDU_2014_2_15

11. Молодцов О. В. Методологічні аспекти теорії інституціональних матриць в контексті динаміки інституціональних змін / О. В. Молодцов // Теорія та практика державного управління i місцевого самоврядування. - 2016. - № 2. - Режим доступу : http://nbuv.gov.ua/UJRN/Ttpdu_2016_2_8

12. Сумцов В. Г. Деформация институциональной матрицы в Украине / В. Г. Сумцов, И. Г. Филиппова // Сборник научных трудов Восточно-украинского национального университета им. В. Даля. 2011. - № 17. - С. 243-247.

13. Шульга М. Збій соціальної матриці : монографія / М. Шульга. Київ: Інститут соціології НАН України, 2018. - 284 с.

14. Панасюк Р. В. Реінжиніринг менталітету людських ресурсів обов'язкова складова процесу успішного управління змінами в соціально-економічних системах / Руслан Панасюк, Віктор Петренко, Христина Попова, Йоанна Ясіньска // International Journal of Innovative Technologies in Economy. - June 2018. - \#5(17), Vol.1. - C.60-68. 
Поліванов В.С., к.е.н., доцент

Київський національний торговельно- економічний університет

\section{ПАТЕРНАЛІЗМ ТА ЛІБЕРАЛІЗМ У НОВІЙ ПАРАДИГМІ ЕКОНОМІЧНОЇ СИСТЕМИ}

Розвиток економічної думки в останні десятиріччя - це історія взаємного збагачення лібералізму і патерналізму, намагань досягти оптимального балансу між ними. Послідовно заперечуючи один одного, тим не менше, обидві моделі запозичували одна у одної найбільш важливі сутнісні характеристики. Вся еволюція економічної системи, так само як i етапи трансформації ліберальної та патерналістської іiі моделей, вирізняються чітко окресленим діалектичним взаємозв'язком. Тому не варто абсолютизувати протистояння патерналізму та лібералізму, більш доцільно розглядати суперечності між ними як діалектичні, тобто такі, що постійно розвиваються і трансформуються.

Кожна країна сама визначає ступінь і форми державного впливу на економіку, однак різноманітність механізмів цього втручання ставить проблему 3'ясування масштабів присутності держави в економіці однією з ключових і найбільш дискусійних в економічній теорії. Сформувалося два принципово різних підходи щодо місця і ролі держави та іiі соціальних функцій. Перший 3 них базується на жорсткому державному патерналізмі, масштабній підтримці найбільш вразливих верств населення за рахунок бюджетних коштів. Обмеженість та вади цього підходу з урахуванням сучасних реалій як вітчизняної, так й світової економіки та перспектив їх розвитку в осяжному майбутньому $\epsilon$ очевидними. I хоча державні соціальні видатки зростають, проблема подолання бідності не вирішується.

В основі іншого підходу лежить прискорена реалізація моделі ліберальної держави, заснована на принципі ії відповідальності лише за надання мінімальних соціальних послуг, а все інше громадяни повинні забезпечувати самостійно. Соціальні видатки при цьому перерозподіляються на користь найбідніших прошарків населення, за рахунок скорочення соціальних трансферів заможним родинам. 
Для більш глибокого розуміння механізму взаємодії патерналістського та ліберального підходів слід проаналізувати їх зміст та еволюцію.

Патерналізм (від лат. patemus - батьківський, батьківська турбота) - переконання, що держава, влада (уряд) зобов'язані турбуватись про своїх громадян, забезпечувати задоволення їх потреб за державний кошт, брати на себе піклування про добробут.

Як економічна категорія патерналізм - специфічна форма економічних відносин, що знаходить свій вираз в наданні патерналістської допомоги юридичним i фізичним особам економічними суб'єктами, що знаходяться на більш високому рівні. Патерналістська допомога виступає у формі безоплатної матеріальної та грошової допомоги, безкоштовних соціальних послуг.

Теоретичний внесок в дослідження проблем патерналізму як елемента існуючої парадигми економічної системи зробив Дж. М. Кейнс [1]. Своє логічне завершення цей напрям економічної теорії отримав в працях Дж. Гелбрейта [2], В. Леонтьева [3] та інших. 3 вітчизняних науковців дану проблему досліджували В.М. Геєць[10], В.П. Онищенко [11], Т.І. Артьомова[12] та інші.

Патерналістські відносини характеризуються як особлива система взаємозалежностей між індивідами, які перебувають в жорстокій ієрархії. Змінюючись, стаючи більш формальними, вони можуть бути присутніми і в сучасному суспільстві.

В економічній теорії зміщення теми патерналізму з периферії наукового знання у фокус активного дослідження відбулось у середині $60-\mathrm{x}$ років XX століття. Його основна місія полягає у підтримці механізмів соціального контролю і послабленні напруги і конфліктів в розколотих суспільствах. Джерелом для виникнення таких відносин $€$ дефіцит міжособистісної довіри.

В соціальній структурі багатьох країн світу сформувались два нерівноцінних прошарки населення - заможні та бідні. Перші практично досягли найвищих стандартів життя. Доходи інших навіть не дотягують до прожиткового мінімуму, вони впали нижче вартості споживчого кошика, тобто до рівня злиденності. В межах цього прошарку швидко зростає застійна бідність 3 притаманними йому нормами і стереотипами поведінки.

Навряд чи можна погодитись 3 думкою тих науковців, які зводять будь-яку форму державного патерналізму лише до соціального утримання. Інше питання, що ступінь такого патерналізму визначається цілями розробленої в конкретній країні соціальної політики. 
Лише теоретично можна уявити державу з абсолютною нестачею принципів патерналізму в широкому його розумінні, оскільки фактично це означає відсутність в ній функції соціального захисту населення.

Як справедливо підкреслює В.М. Геєць у «сфері соціальної політики державний патерналізм слабшає. Внаслідок зміни моделі функціонування економіки (держава більше не $є$ головним власником i розпорядником економічних ресурсів і життєвих благ) патерналізм як принцип державного управління заміщується іншою системою відносин залежності - між суспільством та кланово-олігархічними групами. Крім того, з об'єктивних причин через зміну поколінь очікування щодо держави як головного постачальника життєвих благ $\mathrm{i}$ гаранта соціального добробуту зменшуються. Водночас інноваційні форми підприємництва розвиваються поза державним контролем i впливом. Громадянська активність і соціальний капітал слугують більш потужними чинниками економічного розвитку, ніж урядові регуляторні заходи» $[10$, с. 4]. Це створює певні передумови поступового переходу до ліберальної системи.

Слід зазначити, що дискусії про лібералізм та неолібералізм за останні роки набули гострих форм. Однак, як зазначає В. Автономов, «далеко не завжди ії учасники однаково розуміють іiї предмет» [4, с. 5]. Для цього доцільно зробити короткий ретроспективний аналіз лібералізму. Ліберальну модель економічної системи досліджували Ф. Бастіа[5], А. Мізес[6], Ф. Хаєк[7], В. Ойкен[8], М. Фрідмен[9] та інші.

Поняття «лібералізм» в економічній думці вживається в різних значеннях. Ф. Хайєк відзначив, що фундаментальним принципом лібералізму є «політика, що свідомо обирає в якості впорядковуючи основ, конкуренцію, ринок і ціни» [7, с. 118]. Центральна ідея класичного лібералізму - свобода в рамках закону.

Економічний лібералізм виник зусиллями Д. Рікардо та інших «філософських радикалів», які розвивали ідеї А. Сміта та відстоювали свободу торгівлі та скасування протекціоністських обмежень. В кінці $\mathrm{XIX-} \mathrm{на} \mathrm{початкуXX} \mathrm{століття} \mathrm{етап} \mathrm{класичного} \mathrm{лібералізму} \mathrm{змінився}$ етапом переважання національних інтересів. В середині 70 -х років XX століття кейнсіанська політика стимулювання попиту поступилась ліберальній політиці з боку пропозиції (рейганоміка і тетчеризм були головним їі втіленням).

Після краху соціалістичної моделі у Східній Свропі здавалось, що ліберальні ідеї остаточно перемогли. Однак, в подальшому неолібералізм став головним об'єктом критики антиглобалістів і противників «Вашингтонського консенсусу». В останній час в 
суспільній думці домінує явний або прихований антагонізм щодо лібералізму. Дана обставина зумовлює великі коливання щодо ставлення суспільства до економічного лібералізму. Це має привести до висновку, що суспільство далеко не завжди вважало його природною, очевидно оптимальною системою економічної політики. Емпіричні дослідження свідчать, що ліберальні погляди пов'язані 3 високим рівнем освіти, що цілком обгрунтовано: патерналізм більш зрозумілий, а для прийняття лібералізму потрібні певні інтелектуальні зусилля.

Ліберальні реформи, більш або менш успішні спроби проведення яких робились в країнах Центральної та Східної Свропи, мали яскраво виражений патерналістський характер. В зв'язку з цим логічно виникає питання: на які засадничі принципи має спиратись реалізація ліберальної економічної політики? В працях класиків лібералізму містяться дві основні відповіді: відносно високе місце свободи в ієрархії загальнолюдських цінностей і прагматичний розрахунок. 3 великою вірогідністю можна стверджувати, що в країнах, в яких спираються на обидві зазначені підстави, ліберальна політика, зокрема ліберальні реформи, здатна підтримувати себе сама і має чіткі перспективи практичного втілення. Якщо ж перша підстава відсутня i спиратися залишається лише на прагматичний розрахунок, то має місце так званий патерналістський «лібералізм» з незначними шансами на успіх.

Погоджуємось 3 твердженням Т. Артьомової, «що ринкова система ліберального типу, звичайно, не $є$ ідеальною, але вона виявила свою життєздатність в умовах жорсткої конкуренції, і це є доказом того, що всі інші економічні системи є менш ефективними. При цьому країни і народи, що не усвідомлюють величі історичної ситуації, і не здатні або не бажають прийняти і розділити традиційні цінності європейського життя стають на заваді справжньому прогресу i загальному добробуту» [12, с.19].

\section{Список використаних джерел}

1. Кейнс Дж. М. Общая теория занятости, процента и денег. М.: Экономика, 1992. - 432 с.

2. Гелбрейт Дж. Новое индустриальное общество / Дж. Гелбрейт. Пер. с англ.: под общ. ред. Н.И. Иноземцева. - М.: Прогресс, 1969. $-480 \mathrm{c}$.

3. Леонтьев В. Экономические эссе. М.: Прогресс, 1990. - 475 с. 
4. Автономов В. На какие свойства человека может опереться экономический либерализм // Вопросы экономики, - 2015. - №8. - C. 5-24.

5. Бастиа Ф. Экономические гармонии. Избранное. М.: Эксмо. 2007. - 329 c.

6. Мизес Л. Либерализм. М.: Экономика; Социум: 2001. - 240 с.

7. Хаєк Ф. Право, законодательство и свобода. Современное понимание либеральных принципов справедливости и политики. М.: ИРИСЭН: 2006. - 644 с.

8. Ойкен В. Основные принципы экономической политики. М.: Прогресс - Универс. - 1995. - 337 с.

9. Фридмен М. Капитализм и свобода. М.: Фонд «Либеральная миссия»; Новое издательство. - 2005. - 437 с.

10. Геєць В.М. Економічну практику - на наукове підгрунття // Економіка України, - 2018. - №10. - С. 3-19.

11. Онищенко В.П. Соціальні передумови економічного розвитку України // Економіка України, - 2017. - №9. - С. 19-35.

12. Артьомова Т. Свропейські цінності: інтелектуальний простір цивілізаційного діалогу // Економічна теорія, - 2018. - №3. - С. $5-27$.

Романенко В.А., проф., д.е.н., Київський національний торговельно-економічний університет

\section{ЧИННИКИ ФОРМУВАННЯ ПАРАДИГМИ В ЕКОНОМІЧНІЙ НАУЦІ (ІСТОРІЯ І СУЧАСНІСТЬ)}

Теоретико-методологічні трансформації в економічній науці не виникають спонтанно, вони формуються на основі еволюційного наступу. Кожна нова парадигма в економічній теорії народжується, в першу чергу, соціально-економічними потребами суспільства на певному етапі розвитку. Так, великі географічні відкриття дали поштовх до розвитку меркантилізму. Бо саме торгівля, в цей час, особливо-монопольна ставала основним джерелом збагачення. Колоніальна експансія була продиктована потребами розширення торгівлі. Але таке джерело збагачення для європейських країн 3 часом вичерпалось, «... щоб 
підтримувати розширення торгівлі, Свропа повинна була знайти якийсь власний предмет експорту, ї з цим завданням вона блискуче впоралась... Можна вважати, що саме це і слугувало стимулом до зміни характеру промисловості.» [1].

Тобто, наступним джерелом збагачення і економічного наступу стає промисловість особливо обробна, здатна випускати кінцеву продукцію готову до споживання. Така ситуація кардинально змінює економічну думку: на зміну меркантилізму приходить ціла епоха класичної політичної економії. Не дивлячись на беззаперечні наукові досягнення цього напряму, він в значній мірі відображав інтереси англійської промислової буржуазії, а тези щодо невидимої руки ринку, держава-нічний сторож, порівняльні переваги в торгівлі, сприяли поширенню англійських товарів по всьому світу.

Подальший розвиток капіталістичного виробництва 3 його кризами перевиробництва, зростання концентрації і централізації капіталу виводять на арену такі вчення як марксизм і маржиналізм. Кожне 3 яких по своєму будувало свої теоретичні концепції, але не були позбавлені апологетичної сутності.

Економічна криза 1929-33 рр. наочно показала неспроможність рекомендацій ліберального напряму в економічній теорії. Ось тут на арену виходить кейнсіанство 3 новою теоретичною концепцією і відповідними практичними рекомендаціями.

Початок XX століття ознаменувався ще рядом важливих подій: відбувся перехід капіталізму на монополістичну стадію і зросла роль науки, яка в наслідку науково-технічної революції стала важливим фактором виробництва, відбулась також адміністративна революція, яка змінила роль держави в економіці.

Як стверджував M.I. Туган-Барановський:

«...Сучасна держава не боїться діяльно вмішуватися в господарське життя і вона має цілковиту змогу усувати шкодливий вплив капіталістичних організацій різного роду... Але ставити своїм завданням - не допускати самого виникнення картелів, - це значить не розуміти законів капіталістичного розвитку.» [2].

Схожу думку щодо ролі крупного капіталу висловлює Й. Шумпетер. «Як тільки ми продивилися на показники виробництва окремих товарів, то з'ясується, що найбільшого прогресу добилися не фірми, працюючі в умовах порівняно вільної конкуренції, а саме крупні концерни, які до того же сприяли прогресу в конкурентному секторі...» [3]

Говорячи про роль науки в економічному розвитку Дж. Хікс стверджував: «...Дійсно, економіка завжди зростає, відкриваючі нові сфери для інвестицій шляхом досліджень і прогресу знань. Але якщо в 
попередній фразі відкриття носили в основному географічний характер, то за цим слідували наукові дослідження фізичного світу, значно більш широкі, чим чисто географічні. Саме, наука особливо фізика, відкрила нові, майже невичерпні можливості для промисловості [1].

Аналіз Й. Шумпетера також показує, що зростання національної (валової) доданої вартості може забезпечити тільки інноваційний розвиток, що власне й зумовлює тип розвитку економіки, що його Шумпетер назвав «динаміка» [3].

Важливою подією XX століття стала адміністративна революція, критичною датою іiі появи стала Перша світова війна (1914-1918рр.). «...лише під час війни уряди з подивом і часто з розгубленістю зрозуміли, яка страхітлива влада, економічна влада над власним народом виявилася в їхніх руках ... тепер в розпорядженні урядів виявилося значно більш вишукані засоби контролю. Кількісні квоти, монополії на імпорт i експорт, контроль над притоком і відтоком капіталу, маніпуляції 3 податками (навіть на перший погляд чисто внутрішніми). Нові інструменти регулювання винаходяться безперервно» [1].

Виходячи 3 вищевикладеного можна зробити висновок, що основними факторами успішного економічного розвитку розвинутих країн сьогодні $\epsilon$ : наявність крупних організаційних структур у високотехнологічних секторах економіки, зокрема, машинобудуванні, активна інноваційна політика i ефективне державне регулювання економіки.

Економічний розвиток України за останні десятиліття показав, що по жодному з цих факторів вона не наблизилася до розвинених держав. За Україною закріплюється статус аграрно-сировинного придатку розвинутих країн. Виклики які сьогодні стоять перед державою значно підсилюються агресією Росії. Ці обставини вимагають пошуку нової парадигми для обгрунтування стратегії економічного розвитку, оскільки попередні реформи побудовані на засадах неоліберальної концепції показали свою неспроможність вивести країну із довго тривалої кризи.

Вбачається, що основою нової парадигми мають стати політичні і економічні передумови. До політичних слід віднести реалізацію на ділі (а не на словах) розбудови моделі соціально-орієнтованої економіки. Економічною передумовою $\epsilon$ формування економіки нового типу зорієнтованої не на використання лише природно-ресурсного потенціалу (як є нині), а на залученні потужного інтелектуального капіталу для організації власного виробництва наукомісткої продукції та послуг. 


\section{Список використаних джерел:}

1. Хикс Джон. Теория экономической истории. Пер. с англ. /Общ. ред. и вступ. ст. Р.М. Нуреева -М.: НП Журнал «Вопросы экономики», 2003.

2. Туган-Барановський M.I. Політична економія. Курс популярний. Київ, Наукова Думка. 1994 с.140

3. Шумпетер Й.А. Капитализм, Социализм и Демократия: Пер. с англ./Предис. и общ. Ред. В.С. Автономова.-М.: Экономика, 1995.-C.125.

4. Йозиф А. Шумпетер. Теорія економічного розвитку: дослідження прибутків, капіталу, кредиту, відсотка та економічного циклу/ Пер. 3 англ.. В. Старка, -К.: Видавничий дім «Києво-Могилянська академія», 2011.- с.9

Уманців Ю. М., д.е.н., професор, Київський національний торговельно-економічний університет

\section{ВЗАСМОДІЯ ДЕРЖАВИ ТА РИНКОВИХ МЕХАНІЗМІВ ЗА УМОВ ГЛОБАЛЬНИХ ТРАНСФОРМАЦЙ}

Глибинні суспільні трансформації наприкінці XX - на початку XXI ст. поки не супроводжуються належним теоретичним осмисленням вказаних процесів. Усталені уявлення не дають вченим можливості здійснити належний науковий аналіз цілого комплексу складних методологічних проблем, оцінити логіку розгортання нових процесів та визначити їх внутрішню сутність. Йдеться про необхідність критичного переосмислення панівних теорій та формування нових концептуальних і парадигмальних підходів до дослідження трансформаційних процесів. При цьому особливої уваги потребує методологічне підгрунтя, спроможне забезпечити розкриття сутнісних передумов трансформації співвідношення між державним впливом на економічні процеси та ринковим саморегулюванням $[1, \mathrm{c}$. 7-8].

Глобальний розвиток на початку XXI ст. ознаменувався розгортанням нового етану у розвиткові держави як суспільного 
інституту, що обумовлено політичною трансформацією та економічною адаптацією до новітніх умов. У контексті глобалізаційних процесів трансформуються традиційні функції і роль держави у системі економічних відносин. Можна стверджувати про переміщення інституційної рівноваги від ринкових саморегуляторів у напрям інституту держави, яка відіграє системотворчу роль у соціально-економічному розвиткові. В основі розгляду переваг та недоліків втручання держави в економіку в основному перебуває іiі протиставлення ринкові. Водночас держава і ринок не заперечують, а якраз доповнюють одне одного. Беручи до уваги екстерналії ринкового господарства, слід зазначити, що держава і ринок формують надійний фундамент функціонування сучасної економіки та суспільства загалом.

Забезпечення стійкого економічного зростання i досягнення цілей суспільного розвитку перебувають у площині поєднання важелів економічної політики держави й ринкового саморегулювання. Для наукової спільноти очевидно, що на сьогодні проблему взаємозв'язку держави й ринку не слід формулювати у контексті більшої або меншої участі держави в економіці. За сучасних умов ринок і держава виконують притаманні їм функції, які взаємно доповнюються та балансують одна одну. На цьому підгрунті можна одночасно підвищувати роль держави в економіці та розвивати ринкові механізмі. Тому на зміну ліберальному підходові, коли, що менше держави в економіці, то краще, та принципові необгрунтованого зростання ролі держави, слід перейти до підходу, відповідно до якого повинно бути «більше держави і більше ринку». За цих умов ринок реалізує перш за все приватні інтереси, а держава відстоює прагнення суспільства загалом. У цьому зв'язку для України пріоритетним $є$ такий варіант трансформації економічної системи, який би одночасно спирався на лібералізацію та дерегуляцію економіки, а також використовував потенціал ринкових механізмів і спроможність держави усувати структурні деформації 3 метою динамічного та збалансованого розвитку [2, с. 20]. Таку ж позицію обстоює й С. Кораблін, вказуючи, що роль держави в економіці має бути не мінімальною, а навпаки істотною. Найважливіше питання при цьому пов'язане не 3 масштабами держави, а 3 конкретними напрямами та методами іiі впливу на економічні процеси. Вчений наводить досвід розвинених країн, в яких доволі широкою є сфера відповідальності держави [3. с. 54].

Т. Пікетті аргументує думку про те, що «як антиринковий, так і антидержавний підходи частково правильні», а тому необхідними $\epsilon$ нові інструменти державного втручання в економіку [4, с. 480]. У 
цьому контексті Р. Райх доводить, що існування ринків залежить від правил, які регулюють відносини власності, рівень монополізації ринку, контракти та правила банкрутства. Очевидно, що такі правила не $\epsilon$ природним законом, а для їхнього функціонування вони мають бути ухваленими певною інституцією. Протягом останніх десятиліть вказані правила зазнавали змін, оскільки великі корпорації та найбагатші особи здійснюють щоразу більший вплив на ті політичні інститути, котрі відповідають за ухвалення таких правил. Вчений зазначає, що не існує жодного «вільного ринку» без уряду, оскільки такого ринку взагалі не існує поза впливом цивілізації. Йдеться про те, що цивілізація детермінується правилами, а самі ринки й створюються такими правилами, що своєю чергою розробляються урядами. Якраз ринок і вимагає від уряду запровадження та дотримання чітких правил, а тому уряд не лише втручається у вільний ринок, а й створює його. Такі ринкові правила не $\epsilon$ постійними, тому що суспільства у певний час ухвалювали різні їхні варіанти, які певною мірою віддзеркалюють еволюцію норм та цінностей суспільства, але також й демонструють, які інститути мають змогу встановити правила. Норми функціонування вільного ринку чинять значно більший вплив на економіку та суспільство, оскільки неможливим $є$ існування ринкової системи без вказаних правил та можливостей вибору, що гарантуються такими правилами [5, с. 22].

Отже, якраз через це, на думку Р. Райха, «вільний ринок» є міфом, який перешкоджає дослідженню змін правил функціонування економіки. Суб'єкти несправедливого впливу на правила ринку є найбільшими вигодонабувачами того, як саме ці правила розробляються та адаптуються до економічних умов. Саме тому вказані суб'єкти $є$ найбільш активними прихильниками «вільного ринку» та обстоюють при цьому думку про відносну перевагу ринку над урядом. Прихильники «вільного ринку» вимагають не тільки погодитися 3 ними у питанні про його переваги, а й визнати необхідність постійної дискусії з цього приводу [5. с. 23].

Сучасний ринок слід розглядати як нерівноважну динамічну систему, в якій рівновага є здебільшого винятком, ніж правилом його існування. Зараз відбувається глибинна системна реконструкція найважливіших функцій держави, котра пов'язана з глобалізаційними процесами та розвитком постіндустріального інформаційного суспільства. Протягом останніх десятиліть ринок втрачає свою спроможність виконувати інформаційну функцію й дуже часто ринкова інформація вже не є репрезентативною [6, с. 401-415]. 
За умов глобального конкурентного простору економічні функції держави суттєво модифікуються, що виражаються не лише у перегляді концептуально-методологічних засад теорії державного регулювання, але й у зміні напрямів, форм і методів регулювання. При цьому йдеться про те, що міждержавна система територіальної моделі регулювання поступається місцем умовам, за яких кордони та межі держави долаються глобальним характером сучасних ринків. Очевидно, що роль держави суттєво змінюється під впливом глобалізації, а висновок про зниження ії регулюючої ролі $є$ не надто обгрунтованим. Беручи до уваги втрату державою внаслідок глобалізації деяких іiі функцій, слід звернути увагу при цьому й на поступове посилення та модифікацію форм державного втручання в економічні процеси.

У цьому зв'язку не лише теорія, але й практика свідчать про зниження рівня дієвості власне ринкових механізмів, що підтверджується перебігом глобальної фінансово-економічної кризи 2008-2009 рр. та величезними втратами світової економіки. Саме тому світове господарство перебуває на порозі суттєвого посилення ролі держави. За цих умов дискурс світового розвитку переміщується у формат «людина - держава - глобальне суспільство». До цілої низки вже традиційних проблем додаються такі гострі виклики, як величезні обсяги міграції, глобальні економічні проблеми, зростання проявів тероризму. Змінюючи свої функції, держава залишається базовою конструкцією нової глобальної архітектоніки [7, с. 593-607]. Уникнення системного відновлення кризових явищ буде залежати від тривалості та глибини дії ризиків макроекономічної незбалансованості [8, с. 14-19].

Важливим завданням для наукової спільноти є переосмислення нових викликів, які постали перед світовою економікою. Дискусії щодо перспектив розвитку мають відбуватися у напрямі теоретичного обгрунтування створення дієвих механізмів регулювання, гармонізація яких на всіх рівнях забезпечить передумови, що дозволять у подальшому мінімізувати ризики порушення стійкості світового господарства.

\section{Список використаних джерел}

1. Лагутін В. Д. Цивілізаційні та інституційні фактори глобальних економічних трансформацій XXI ст. / В. Д. Лагутін // Зовнішня торгівля: економіка, фінанси, право. - 2019. №2. - с. 5-19 
2. Гриценко А. А. Сучасна криза у контексті логіки соціальноекономічного розвитку / А. А. Гриценко // Економіка України. - 2015. - №6. - c. 18-37

3. Кораблін С. О. Макроекономічна динаміка України: пастка сировинних ринків / С. О. Кораблін. - Київ: Ін-т екон. та прогнозув. НАН України, 2017. - 308 с.

4. Пікетті Т. Капітал у XXI столітті / T. Пікетті. Пер. 3 англ. Н. Палій. - Київ : Наш Формат, 2016. - 696 с.

5. Райх Р. Врятувати капіталізм. Як змусити вільний ринок працювати на людей. Пер. 3 англ. Р. Корнути. - Київ: Наш формат, 2018. - 288 c.

6. Гальчинський А. С. Економічна методологія. Логіка оновлення / А. С. Гальчинський. - Київ: АДЕФ-Україна, 2010. - 572 с.

7. Кравчук Н. Я. Дивергенція глобального розвитку: сучасна парадигма формування геофінансового простору / Н. Я. Кравчук. Київ: Знання, 2012. - 782 с.

8. Фінансова глобалізація і євроінтеграція / за ред. О. Г. Білоруса, T. І. Єфименко. - Київ: Акад. фін. управління, 2015. - 496 с.

Філіпенко А.С., д.е.н., професор,

Київський національний університет імені Тараса Шевченка

\section{МІЖДИСЦИПЛІНАРНІСТЬ У ЕКОНОМІЧНІЙ МЕТОДОЛОГІЇ: ФІЛОСОФІЯ, ЛОГІКА, МАТЕМАТИКА}

Складність і водночас сила економічної методології полягає в тому, що вона спирається на три фундаментальні науки: філософію, логіку та математику. Філософські засади формують науковий світогляд, логіка створює логічні передумови економічного аналізу, математика наближає економічну теорію до природничих наук.

«Методологію економічної науки, - писав М. Блауг,- слід розуміти просто як філософію науки в іiі застосуванні до економіки» [1, с.35]. Філософія науки $є$ основою філософського трактування економічної теорії, яка відображає складний, всеосяжний, безмежний економічний світ. Філософська рефлексія економічної науки продовжує інтелектуальний ряд філософського бачення таких наук, як право, 
політика, етика, антропологія, природничі науки. Зазначені праці $\epsilon$ прерогативою, як правило, самих філософів, так і представників відповідних наук, зокрема, економістів-методологів. Для економічної теорії основоположне значення мають п’ять положень філософії науки.

1. Цілі. Якими є цілі науки та наукового теоретизування? Чи є наука насамперед практичною діяльністю 3 метою виявлення корисних узагальнень, чи вона повинна займатися пошуком пояснень та істини?

2. Пояснення. Що таке наукове пояснення?

3. Теорії. Що таке теорії, моделі і закони? Як вони співвідносяться одне з одним? Як вони відкриваються та будуються?

4. Перевірка, індукція та демаркація. Як перевіряються та підтверджуються (чи спростовуються) наукові теорії, моделі і закони? Як розрізняються установки і практики у вчених та у представників інших професій?

5. Чи однакові відповіді на ці чотири запитання дають усі науки в усі часи? Чи можна вивчати людські поступки та інститути так само, як ми вивчаємо природу?( 2, с. 5).

Відповіді на ці та подібні запитання формулюються 3 різних світоглядних, філософських, методологічних позицій.

Природа економічної методології складається 3 трьох базових опор. По-перше, економічна методологія досліджує природу економіки як науки. Це означає, що економічна методологія розглядає структуру та засновки пояснень i тверджень, які здійснюють економісти 3 метою відповіді на питання щодо функціонування економічного світу. По-друге, економічна методологія використовує як дескриптивний (описовий) та і прескриптивний (нормативний) підхід. Дескриптивна економічна методологія має на меті описати різні типи практики економічних досліджень, а також їхні результати. У філософії науки дескриптивна методологія часто позначається як позитивна методологія. Прескриптивна економічна методологія спрямована на здійснення якісних оцінок пояснень в економіці та на удосконалення категоріального апарату економічної теорії. Філософи науки характеризують прескриптивну методологію як нормативну методологію, а також переймаються питанням того - як наука повинна впроваджуватися на практиці. По-третє, принциповим моментом економічної методології $є$ питання про те, що є спільним та відмінним в економічній науці у порівнянні 3 природничими та фізичними науками (3, с. 2-4). Як випливає з наведеного, у даному випадку маємо приклад філософського трактування економічної методології. 
Однак практика економічних досліджень засвідчує широке використання логіки та математичної методології як важливих засобів отримання нових наукових результатів та нових знань.

Логіка є мовою економічної науки, яка вибудовує її архітектоніку в логічній послідовності згідно з законами логічного мислення, напрацьованими тисячоліттями як давніми, так i сучасними мислителями. Дж. М. Кейнс у листі до Р. Харрода зазначив, що економічна теорія - це гілка логіки, образ мислення [4]. Спосіб мислення епохи - це використання універсальних понять та ідей, наповнених змістом, що відповідає певній епосі. У ньому розкриваються історичні відмінності логічних ланок розвитку мислення. Розрізняють побутову (людську), формальну, діалектичну, логіку науки та ін. Не заперечуючи значення усіх форм логіки, зазначимо, що для з'ясування логічних передумов економічної теорії головною є логіка науки.

У провідних економічних концепціях сучасності превалює детерміністична логіка. Детерміністична (базова) логіка неокласичної економічної теорії полягає в урахуванні всієї множини можливих факторів (економічних та неекономічних), що впливають, наприклад, на перебіг цін. Індивідуальні потреби, уподобання, продуктивна спроможність, взаємодія індивідів є головними у формуванні обліку економіки.

Кейнсіанська детерміністична логіка має структурний характер, за якої поведінка індивідуумів зумовлюється загальним станом економіки як цілого (холістична методологія). Логіку марксистського економічного аналізу називають наддетермінізмом, який є похідним від діалектики. Така логіка вибудовується на основі значно більшої кількості чинників, ніж неокласична. Наприклад, падіння виробництва пояснюється не тільки скороченням інвестицій, споживання, зниженням біржових цін та інших подібних детермінант. Сюди включаються ще численні приклади як-то: економічні зміни в класовій структурі, зміни клімату та стану земельних угідь, зміна політики банківського регулювання, виборів і законодавства, культурні зміни в споживанні, рівень заборгованості, довіра в галузі бізнесу тощо (5, с. $39-41 ; 44-46)$.

Зазначені визначення та висловлювання, інші чинні підходи i концепції дозволяють у першому наближенні сформулювати окремі принципи щодо логічних передумов економічного аналізу. На думку В. Леонтьєва, «удосконалена й розширена В . Парето та його сучасниками i послідовниками загальна теорія економічної взаємозалежності... обіцяє стати уніфікованою логічною структурою 3 
двома іншими напрямами аналізу: теорією ринкового механізму та аналізом поведінки фірми і домашнього господарства» (6, с. 116). Основу аналізу взаємозалежності становить теорія загальної рівноваги, як незаперечний принцип та головний стрижень економічної теорії (6, c. 122). Структурна взаємодія, покладена в основу моделі «витративипуск», прямо корелює 3 кантівською трансцендентальною логікою та карнапівською загальною структурною концепцією.

Дж. М. Кейнс розглядав логіку в роботі «Трактат із ймовірності», a у своїх економічних дослідженнях застосовував нечітку логіку, 3'ясовуючи гіпотетичний попит на гроші (7, с. 57-66).

Різноманітні логічні конструкції застосовуються в інституційній та неоінституційній економічній теорії. Зокрема, 3 урахуванням специфіки інституційного аналізу, використовують такі поняття, як складна логіка, конкурентна, ринкова, релігійна тощо. Зазначене не завжди корелює із класичними трактуваннями логіки, яка не спрямована на конкретний предмет. Логіка,- писав Кант, - «містить правила мислення взагалі. Тут має бути абстрагування від усякої відмінності об'єктів, від усякої матерії пізнання» (8, с. 86). У вузькому, редукціоністському значенні, економічна логіка зводиться до теорії раціонального вибору, яка є превалюючою в неокласичній концепції.

Математична гілка економічної методології має глибокі коріння. Платон стверджував, що ідеї, їхнє математичне вираження $\epsilon$ первинними в осягненні всесвіту. Близькими були й погляди Декарта, Лейбніца та ін. Сучасний польський філософ Збігнєв Крол пише, що «соціологічні, економічні, політичні, психологічні, а також інші фактори є вторинними. 3 цієї причини, в теорії створення знань необхідно враховувати як базовий, так і вторинний рівні. Базовий рівень визначається суто раціональними та онтологічними чинниками. Це означає, що наукові зміни в математиці $\epsilon$ раціональними та базуються на об'єктивних умовах, які $є$ пріоритетними в кожній науковій теорії» (9, с. 339). Відштовхуючись від математичних пріоритетів, певного розповсюдження набула модель аксіоматичної будови світу, аксіоматична методологія.

Історія економічної науки взагалі та економної методології зокрема, свідчить про те, що елементи математики завжди були присутні в економічних дослідженнях. Досить згадати економічну таблицю Ф. Кене (1758), «Математичні принципи теорії багатства А. Курно (1835), систему рівнянь теорії загальної рівноваги Л. Вальраса (1874, 1877), «Математичну психологію» Ф. Еджворта (1881), математичні додатки А . Маршалла (1890) та їхніх численних послідовників у XX ст., особливо повоєнні теорії загальної рівноваги, 
в тому числі модель загальної рівноваги Ерроу-Дебре-МакКензі, а також модель Нового Макроекономічного Консенсусу, щоб переконатися у постійному взаємозв'язку та взаємодії цих двох фундаментальних суспільно значимих наук.

Одне 3 ключових методологічних положень полягає у визначенні співвідношення між теорією, моделлю та реальним економічним світом. Більшість теорій можуть бути реалізовані через декілька моделей, залежно від того яким чином задається кожен фактор. Оскільки теорії можуть бути реалізовані за допомогою декількох моделей, зазвичай легше протестувати модель, ніж цілу теорію. Якщо одна модель зазнає невдачі, та ж теорія може надати іншу модель, яка буде більшою мірою співвідноситися з даними. Отже, завданням теорії і методології є обгрунтування моделей, які адекватно пояснювали б реальні економічні процеси. У цьому зв'язку пошлемося на Дж. М. Кейнса про те, що «прогрес в економічній теорії практично повністю полягає в поступовому поліпшенні нашого вибору моделей» [4].

В умовах поглиблення міждисциплінарних досліджень, диверсифікації економічного «імперіалізму», формування постекономічних суспільств вирішального значення набуває інтегративна функція методології. Об'єднання різнорідних, суперечливих одна одній аж до протистояння чи заперечення, економічних концепцій $\epsilon$ можливим винятково на базі наукової раціональності. Базовою конструкцією $є$ філософська методологія в іiі проекції на економічну реальність, на економічну науку. «Емпірикоаналітичні науки ( в тому числі економічна -А.Ф.) розвивають свої теорії, - підкреслює видатний німецький філософ Юрген Габермас, - в рамках самосвідомості, яка невимушено встановлює безперервний зв'язок із засадами філософського мислення: та ж опора на теоретичну установку, що звільняе від догматичних зв'язків та від впливу природного життєвого інтересу, що вводить в оману» [10, с.91] . Такі складові філософської методології, як онтологія, епістемологія, аксіологія у їхніх економічних вимірах сприяють формуванню цілісного уявлення про економічну науку. Зокрема, онтологія окреслює предметне поле економічної науки, яке відображає економічне буття, економічну реальність, економічну діяльність людини, суспільні відносини в процесі створення багатства (благ), їхнього розподілу та обміну. На перший погляд, усе просто й зрозуміло. Головні розбіжності існують у тлумаченні того, як працює економічна система, якими є іï базові структури, вихідні положення, інструментарій, методи дослідження. Дуже часто вододіл проходить між продуктовою та поведінковою онтологією, коли перебільшується 
значення однісї з них за абстрагуванні від іншої. Онтологічно розглядаються статичні та динамічні стани економіки, іiі рівноважний та нерівноважний характери, визначеності та невизначеності, ієрархія, системна цілісність тощо. Розбіжності, що об'єктивно існують і будуть залишатися між різними науковими школами, мають певні обмеження чи когнітивні рамки, що вимірюються «одиницями відхилення чи концептуальними варіантами, які циркулюють в даній дисципліні деякий період часу, та одиницями ефективної модифікації, тобто тими небагатьма варіантами, що включаються в концептуальну традицію цієї дисципліни»[11, с. 368]. Зазначені положення становлять, з одного боку, основу методологічного монізму економічної науки та пошуку компромісу і консенсусу (синтезу) між конкуруючими економічними концепціями.

Отже, основні методологічні погляди на економічну теорію дозволяють, з одного боку, пояснювати економічне життя у всіх його вимірах - на мікро,- макро, - та геоекономічному рівнях, встановлювати певні закономірності і тенденції. 3 іншого боку, 3 допомогою різноманітних методів - логічних, математичних, статистичних, комп'ютерних моделей і програм досліджуються нові явища і процеси локального чи глобального характеру, що створює передумови для накопичення емпіричного та теоретичного матеріалу, який збагачує економічну теорію, розвиває економічну науку в цілому.

\section{Список використаних джерел}

1. Блауг M. Методология экономической науки, или Как экономисты объясняют. Пер. с англ. - Москва, 2004.

2. The philosophy of economics. An Anthology. Third edition / Ed. by Hausman D.M. - Cambridge University Press, 2008.

3. Baumans M., Davis J. B. Economic methodology. Understanding economic as a science. - New York, 2010.

4. economia.univ.it/harrod/edition/editionstuff/rfh.346.htm.

5. Wolf R.D., Resnik St. A. Contending Economic Theories: neoclassical, Keynesian, and Marxian. - Cambridge, Massachusetts, London, 2012.

6. Леонтьев В.В. Избранные произведения: в 3 т., Т. 3: Избранные статьи. - Москва, 2007.

7. Dow. Sh. C. and Ghosh D. Fuzzy logic and Kyenes's speculative demand for money. - Journal of economic methodology, Vol. 16, Nr. 1, March, 2009.

8. Кант I. Рефлексії до критики чистого розуму. Пер.з нім. й латини I. Бурковського. - К., 2004. 
9. Krol Z. Platonism and the development of mathematics. Infinity and geometry. - Warszawa, 2015.

10. Хабермас Ю. Познание и интерес. - Философские науки, 1990, № 1.

11. Философия науки: Эпистемология. Методология. Культура: Хрестоматия. - Москва, 2006.

Хрустальова В.В., к.е.н., доцент

Київський національний торговельно-економічний університет

\section{ПРОБЛЕМИ ПЕСИМІЗМУ ТА ОПТИМІЗМУ У ЕКОНОМІЧНІЇ ДУМЦІ: РЕТРОСПЕКТИВНИЙ ПОГЛЯД}

Вивчаючи події минулого, історія економіки та економічної думки надає можливості вибудовувати схеми причино-наслідкових зв'язків, тобто, резюмуючи минулі економічні погляди, можна прогнозувати майбутній економічний розвиток. Розгляд альтернативних, дуже часто діаметрально протилежних поглядів на ту або іншу проблему дозволяє аналізувати, а також систематизувати тези економічних теорій, оскільки в економічній науці будь-яка ідея у потрібний час може бути затребувана реальною економічною політикою.

Але тут постає питання про достовірність відображення економічних подій, про те, яким чином тлумачити зрушення в економічному розвитку, адже інтерпретуючи їх, протягом розвитку економічної думки розставлялися різні акценти, тим самим надаючи певним зрушенням нових значень, тлумачачи їх як негативні, або якщо такі події мали місце в економічному розвитку, намагатися надати їм позитивного змісту.

3 досліджень, присвячених цій тематиці, звернімо увагу на погляди, ключовими поняттями яких є такі проблемні питання, як оптимістичні та песимістичні погляди на економічний розвиток.

Як правило, під впливом руйнування старої системи умов $\mathrm{i}$ факторів, відбувається злам поглядів на існуючи економічні умови та реалії соціально-економічного стану, що визначають формування оптимістичного чи песимістичного поглядів на подальший економічний розвиток.

Наслідком дезорієнтації соціального спрямування людей $\epsilon$ суспільні потрясіння i, звісно, на суспільство впливає песимізм, втрата 
перспективи, скепсис, духовна зневіра. Нові умови передбачають нову парадигму людського буття, перебудову системи орієнтацій, інтересів, методів мислення, спрямованості поведінки особистості.

Є потреба з'ясувати "вікову мутацію "політичної економії", цієї оптимістичної науки про багатство, в "економічну теорію" песимістичну науку про рідкість та дефіцит" [1, с. 425].

Традиції економічного оптимізму були закладені ще у працях Адама Сміта. Його теоретичні наробки базуються на вірі у гармонію та пронизують оптимізмом всю його економічну концепцію. Це проявляється і у поглядах на перспективи економічного зростання та накопичення капіталу, а також і на взаємовідносинах між класами. А. Сміт розглядав працю як єдине джерелом багатства нації, що є свідчить про зростання добробуту у будь-якій країні. У своїй книзі "Дослідження про природу та причини багатства народів" в якості предмета вивчення політичної економії А. Сміт назвав проблему економічного розвитку суспільства та підвищення його добробуту. Як зазначав М. Кондратьєв, "вся класична праця Сміта про багатство народів написана під кутом зору, які умови та яким чином ведуть людей до найбільшого добробуту, як він його розумів" [2, с.243].

Слід зазначити, що розпочата наприкінці XVIII століття промислова революція зруйнувала статику аграрної цивілізації, надавши глобальній економіці не властиву їй до цього динамічність. Якщо в 1000-1820 pp. ВВП на душу населення в світі в середньорічному обчисленні зростав на $0,05 \%$, то за $1820-1870$ pp. швидкість зростання цього показника збільшилася в 10,6 рази, досягнувши $0,53 \%$ в рік [3, p. 265].

Безумовно, такий господарський стрибок не міг пройти безслідно для світовідчуття людини, яке цілком залежало від природнокліматичних умов у доіндустріальному суспільстві, коли все сприймалося як вічне і не схильне до змін.

3 переходом до індустріальної епохи, створюється та швидко розвивається штучне середовище проживання, людина різко знижує свою залежність від природи і перестає потребувати опори на будь-які догмати. Перебуваючи в таких методологічних межах, наука XVIIпершої половини XIX століття залишалася своєрідною "формою метафізики", за допомогою якої люди поки лише могли "зрозуміти навколишнє середовище". Поступовий відхід від абсолютизму прискорила так звана друга промислова революція, яка традиційно датується 1870-1914 pр. В основі даного технічного перевороту лежали відкриття в області електротехніки, неорганічної хімії, поява яких стало можливим завдяки формуванню прикладної науки. В 
кінцевому підсумку вчені другої промислової революції почали ігнорувати абсолютні принципи як перешкоду на шляху прогресу. Економісти не залишилися осторонь від революційних змін в методології природничих дисциплін і сприйняли зрушення в бік релятивізму у філософії науки. "Приблизно до середини XIX століття, - пояснював Й. Шумпетер, - еволюція науки розглядалася як чисто інтелектуальний процес ... Маркс був першим, хто ... показав, що наука залежить від об'єктивних даних про соціальну структуру і особливо від соціального становища науковців, яке i визначає їх погляд на реальність" [4, р. 69].

В цьому контексті щодо поглядів на подальший економічний розвиток необхідно звернути увагу на песимізм Т.Р. Мальтуса i оптимізм Ж.Б. Сея.

Ш. Жид і Ш. Ріст у своїй "Історії економічних вчень" [5] відокремили школу ліберального оптимізму француза Сея, який представляв "природні закони" вільної конкуренції як світ "гармонії інтересів", від англійських песимістів Рікардо та Мальтуса, створили політичній економії репутацію "похмурої науки" ("dismal science", за висловом британського історика Т. Карлейля). 3 їх концепцій випливало, що "природні закони" аж ніяк не добродійні, а фатальним чином ведуть до перенаселення, класовим розбратам і застійному стану економіки, причому визнається марність зусиль щодо трансформації фатальних законів шляхом реформ або будь-яких інших організованих заходів членів суспільства.

До списку "неспокійних песимістів, кожний з яких був свого часу у моді, за словами історика економічної думки Ентоні Уотмена"... можна віднести "Мальтуса, який був стурбований що робітники занадто розмножуються, а Рікардо турбувався, що землевласники поглинуть національний продукт. Маркс був стурбований з приводу того, що власники капіталу здійснюють відчайдушну спробу його поглинути [6, с. 156].

Саме ідеї щодо неможливості існування вічних істин доводить наявність "екзистенційної кореляції між знанням і суспільством", які стали вкрай популярними в економічній науці XIX-XX століть. Цю позицію поділяв і батько неокласичної теорії А. Маршалл: "... будь-яка зміна у соціальних умовах, ймовірно, потребує нового розвитку економічних доктрин" [7, с. 102].

Аналізуючи зміни, що відбулися у економічних поглядах у XX столітті слід звернути увагу на період 1920-1940-х pp., що породив цілий спектр до цього не відомих господарських феноменів, які підштовхнули економістів до їх комплексного осмислення і пошуку 
сил, що лежать "в основі економічного відновлення і зростання" [8, p. 222].

Структурні зрушення в світовій економіці 1970-х рр. мали далекосяжні соціокультурні наслідки. Розвиток інформаційного сектора 3 властивою йому гнучкою зайнятістю, відсутністю жорсткої географічної локалізації та децентралізацією управління в основі господарських систем розвинених держав, що вилилося у розмиванні характерних для промислової епохи практик раціоналізації i рутинізації всіх сфер суспільної життєдіяльності, які у сукупності знижували градус невпевненості людей у майбутньому. Постіндустріальному соціуму був притаманний інший набір буттєвих характеристик. Актуалізуються проблеми нерівності, розподілу та перерозподілу багатства.

В цьому аспекті слід звернути увагу на працю Т. Піккеті "Капітал у XXI столітті" в якій він досліджує причини та наслідки економічної нерівності у світі, механізми накопичення і перерозподілу багатства [9]. Т. Пікетті не лише розглядає закони, здатні впливати на збільшення прірви між найбагатшими і найбіднішими, - він пропонує власні радикальні методи зупинення цієї "нескінченної спіралі" - держава повинна реагувати на зростаючу прірву між багатими і бідними. Він стверджує, що існує тенденція до гіперконцентрації благ, а також говорить про появу нового класу "суперменеджерів" [9, с. 315-321]. Згідно 3 дослідженням Т. Пікетті, капіталістичний світ в новому тисячолітті буде настільки ж пронизаний нерівністю, як це було за часів публікації класичних праць з політичної економії А. Сміта, Д. Рікардо і К. Маркса. Висновки, до яких приходить автор, схожі на побоювання Т. Мальтуса, чия теорія свого часу дозволила заговорити про економіку як про "похмуру науку".

Незважаючи на пронизливий песимізм Т. Пікетті, можливо, катастрофічну траєкторію розвитку капіталізму ще можна змінити, задіявши соціальні інститути і людський розум. Так, Макклоскі Д.Н., зазначає, що найбільшим недоліком дослідження Т. Піккеті, є те, що у "визначення багатства Піккеті не включає людський капітал, яким володіють робітники і який у багатих країнах зріс до того, що став основним джерелом доходів у сполученні з розпочатим у 1800 році накопиченням гігантського капіталу у вигляді знань та соціальних звичок, які належать всім, хто має до них доступ" [6, с. 169].

Кожна економічна теорія виникала у конкретній країні, де існувала певна економічна і політична система і був досягнутий певний рівень розвитку техніки і технологій, культури і науки. Все це мало вплив на авторів доктрин i теорій. Економічні проблеми, які в 
національній економіці були найбільш гострими, ставали об'єктом i предметом економічного дослідження.

У цих визначеннях підкреслювалася важливість врахування проблеми вибору в умовах обмеженості ресурсів. Однак час сильно змінив і господарську дійсність, і поведінку економічних агентів. Сьогоднішня економіка заснована на інноваціях, принципах реінжинірингу процесів і господарських явищ, тобто на критичному ставленні до будь-яких усталених знань і стереотипів.

Безумовно, постулати Т. Пікетті ще не раз будуть піддані критиці, але один з них спростувати швидше за все не вдасться: капіталістичний світ рухається до поглиблення нерівності, і цей процес складно повернути. Одного введення прогресивної шкали оподаткування буде недостатньо для купірування проблеми нерівності, і цей висновок безпосередньо випливає з самої теорії. Уряди повинні створювати стимули для інвестування в людський капітал - інтегральний елемент сил конвергенції, що лежить в основі соціально-політичного розвитку людства.

Власне саме людський капітал став основою інтелектуального ресурсу розвитку, який продовжує накопичуватися у XXI ст. Адже саме завдяки масовій інтелектуалізації розвитку важливо не лише захистити національний життєвий простір, а й отримати власні конкурентоспроможні ресурси для розвитку i завдяки цьому не опинитися на узбіччі цивілізаційних процесів.

Слід зауважити, що збереження в подальшому стабільно високих темпів економічного зростання можливе, коли буде здійснюватися нагромадження соціального капіталу. В такому разі відбуватимуться процеси активізації соціальних перетворень передусім в економічному відношенні, оскільки інновації соціального характеру, а також технологічна культура, які визначатимуться освітою, науковотехнологічними перетвореннями, інтелектуальним підприємництвом сприятимуть рівноправній співпраці при зростанні конкуренції у глобалізованому світі.

\section{Список використаних джерел}

1. Waterman A.M. Adam Smith and Malthus on high wages. Europeean Journal of the History of Economic Thought, 2012, no. 19, p. 409-429/

2. Кондратьев Н.Д. Избранные сочинения. М., 1993, с. М.: Экономика, 1993. - 543 с.

3. Maddison A. The World Economy: A Millenial Perspective. Paris: OECD, 2001. 
4. Shionoya Y. Joseph Alois Schumpeter: The Economist of Rhetoric // Backhaus J. (ed.). Handbook of the History of Economic Thought: Insights on the Founders of Modern Economics. Heidelberg: Springer, 2012

5. Жид Ш., Рист Ш. История экономической учений / Пер. с фр.М.: Экономика, 1995. - 456 с.

6. Макклоски Д.Н. Измеренный, безмерный, преувеличенный и безоновательный пессимизм /Экономическая политика. 2016. Т. 11. № 4. C. 153-195.

7. Історія економічних вчень: Навч. посібник / В.М. Двінських, Н.В. Шибаєва та ін. За ред. Архієреєві С.І., Решетняк Н.Б. - Третє видання (стереотипне). - Харків: НТУ «ХПІ», 2004.- 216 с.

8. Hodgson G.M. The Evolution of Institutional Economics: Agency, Structure and Darwinism in American Institutionalism. L.-N.Y.: Routledge, 2004.

9. Пікетті Тома. Капітал у XXI столітті/ Тома Пікетті ; пер. з англ. Наталії Палій. - Київ: Наш Формат, 2016. - 696 с.

Шевчук В.О., д. е. н., професор, Національна академія статистики, обліку та аудиту

\section{ЖИТТЕСТВЕРДНИЙ СТАТУС ПИТОМО УКРАЇНСЬКОГО ЗНАННЯ: СТАНОВЛЕННЯ ПАРАДИГМИ РЯТІВНОГО ЕКОНОМІЧНОГО МИСЛЕННЯ}

...Розкриваючи квінтесенцію одного зі своїх "Листів до братівхліборобів", фундатор державницького напряму в українській історичній і політичній думці В.Липинський наголошував: "ніхто нам не збудує держави, коли ми самі іï не збудуємо, і ніхто з нас не зробить нації, коли ми самі нацією не схочемо бути" [1, с. 158]. Нині, майже через сторіччя після того, як це написано, контекст листа видатного українського ідеолога державотворення належить трактувати як невідкладність звернення до питомо національних цінностей розбудови України, які залишаються непорушними і в XXI ст.

У той же час теперішні примхи історичної долі в бутті суспільства і держави нерідко пов'язують із проявами демократії як домінуючої в сучасному світі форми правління. 3 метою виправдання 
непередбачуваних проявів демократії наводять як аргумент окремі емпіричні узагальненння, взяті зі світової політичної історії. Зокрема, в досліджуваній ситуації політики і навіть науковці цитують фрагмент із промови В.Черчилля у Палаті Громад 11 листопада 1947 року, коли той, будучи представником опозиції у Британському парламенті, беззастережно зауважив, ніби "ніхто не робить вигляд, що демократія $\epsilon$ досконалою або в усьому правильною. Насправді, як це було сказано, демократія $\epsilon$ найгіршою формою правління..." [2].

Доречно наголосити, що вже згаданий В.Липинський за наслідками дослідження форм правління найбільших держав усіх континентів тодішнього світу, прийшов до висновку про обмежене число політичних ідей та відповідних їм методів організації для розв'язання проблем державного буття. Докладний аналіз дав В.Липинському можливість бачити майбутнє України "не в формі диктатури (охлократія), ані в формі правління при помочі шахрайств виборчих (демократія), ... а в формі класократії" [3, с. 125].

Закономірно торкаючись суспільно-господарських проблем, В.Липинський сформулював висновок про те, що "в цілім світі йде тепер боротьба не на життя, а на смерть двох законів: закону землі й закону капіталу... Це боротьба двох непримиримих світоглядів... Це боротьба двох виключаючих себе взаємно соціальних укладів... Між законом землі й законом капіталу не може вже бути компромісу" [3, с. $181,182,183]$.

Уповні модерний висновок В.Липинського унікально узгоджується із результатами критичного аналізу загальнолюдської економічної думки, здійсненого сучасним українським мислителем, письменником i правозахисником М.Руденком. Незалежно від В.Липинського він прийшов до узагальнення про те, що каркас структури сучасного світового економічного знання утворюють дві основоположні теорії: одна із них створена Ф.Кене, інша - А.Смітом [4, c. 381-382].

Спадщина нашого сучасника засвідчує безкомпромісну критику смітіанства і марксизму, адже хибність їхнього визначення субстанції вартості "зробили XX століття найкривавішим періодом земної історії" [4, с. 477]. Натомість фізіократія не є засобом встановлення диктатур, інспірування заколотів, революцій чи воєн. "Із теорії фізіократів випливає, - показав М.Руденко, - що справа не в революціях, а в плодючості землі" [4, с. 235].

Висновок М.Руденка узгоджується із положеннями В.Липинського, який стверджував, що "часи революції вже минають. I ... Знов той самий український плуг ... мусить нові пустирі, нові 
пожарища зайняти, розорати й засіяти. А це вже не революція, це повільна, тяжка, будуюча праця". Збіг висновків В.Липинського i М.Руденка вказує і на причини невдач новітніх українських революцій 90-х, 2004 та 2014 років і застерігає суспільство від подальших політичних провалів.

"...У яких формах буде виконуватись ця праця, - розмірковував далі В.Липинський, - про це хай рішають між собою організовані в свої професійні організації, в свої "ради" самі працівники: творці хліба, товарів і техніки..." [3, с. 193]. Цей висновок В.Липинського ілюструє його класократичний підхід до побудови державних і самоврядних структур модерних суспільств.

Найбільш симптоматичним положенням, яке органічно споріднює класократію В.Липинського зі світоглядною позицією М.Руденка, є осягнення українськими інтелектуалами відмінностей між продуктивним та "безплідним" класами колишніх, теперішніх $\mathrm{i}$ прийдешніх суспільств. Окреслюючи майбутню Українську державу в формі класократії, В.Липинський наголошував, що іiі "опорою, фундаментом i охороною буде український хліборобський клас... Допустивши до влади всі інші українські класи..., не він має бути одинокою правлячою верствою..., але він має творити найважнішу, консервативну, оберігаючу державу, частину цієї верстви" [3, с. 125]. М.Руденко показав, що "коли класи визначаються за Кене, ... зникають причини для класової боротьби і для політичних спекуляцій на цій основі" [4, с. 122].

...У контексті досліджуваних проблем вельми важливим для осягнення загальнолюдської значущості національного внеску до світової скарбниці політичної та економічної думки видається 2020 рік. Якраз майбутнього року виповнюється 100-ліття з часу появи "Листів до братів-хліборобів" - основоположних праць теоретика і практика класократії В.Липинського. Саме вони $є$ питомо українським політичним знанням глобальної значущості.

2020 року також виповнюється 140-а річниця заснування української наукової школи фізичної економії. Їй правомірно належить статус світової. Для окреслення майбутнього розвитку економічного мислення, господарювання та урядування іiі роль $€$ визначальною. Саме вона формує для власної нації і цілого людства русло рятівної економіко-філософської культури, яка $є$ питомо українською.

2020 року збігаються в часі: 170-ліття засновника національної наукової школи, ученого-новатора і громадського діяча доктора Сергія Подолинського; 75 років з часу, як відійшов у Вічність видатний подвижник фізичної економії - фундатор Української академії наук 
академік Володимир Вернадський; 100-річчя сучасного мислителя, письменника і правозахисника, Героя України Миколи Руденка.

...Становлення національної наукової школи розпочалося 1880 року, коли в числі 4/5 петербурзького журналу «Слово» побачила світ наукова розвідка «Труд человека и его отношение к распределению энергии» [5]. Автором був 30-літній український дослідник доктор С.Подолинський.

Якраз він, за переконанням академіка В.Вернадського, самостійно усвідомивши порушені «батьками» термодинаміки ідеї енергетичної відмінності живого від мертвого, першим у світі застосував їх до вивчення економічних явищ [6]. М.Руденко доводив, що «його місце належить бачити серед економічних геніїв світу» $[4$, с. 465].

Зроблений ним внесок у золотий фонд світової економікофілософської культури можна осягнути і належно поцінувати лише на тлі новітньої наукової картини світу. Її риси, що вимальовуються лише зараз, були геніально вхоплені українським новатором ще наприкінці XIX ст. Його аналіз перетворень одних видів енергії в інші, розгляд людини і людства як теплових машин, його модель енергетичного бюджету людства, дослідження енергетичних процесів у планетарному та вселенському вимірах є піонерною імплементацією термодинаміки в українську і світову фізико-економічну науку.

Цими новаторськими кроками він понад століття тому змінив досі існуючу парадигму мислення і господарювання на фізикоекономічну. Саме він довів, що джерелом додаткової вартості $є$ не праця, а вловлювана працею енергія Сонця. Проте навіть фахівці ще не вповні усвідомлюють значущість його внеску в теоретичну економію та історико-економічну думку. Лише окреслюється бачення новизни здійснених ним наукових розвідок.

Видатний мислитель i натураліст академік В.Вернадський підтвердив фундаментальність положень свого попередника про поновлювану енергію та живу речовину, які завдяки людському розуму і спрямованою ним працею витворюють додаткові блага. Започатковуючи за Вернадським фундаментальні фізико-економічні теорії біо-, гео- і ноосфери, створюючи прикладну фізичну економію живого, неживого й розумного, українство i людство здатні уподібнювати економіку природі, «вписувати» господарювання у довкілля i в такий спосіб протистояти обкраданню власних та загальнолюдських нащадків.

У праці «Кілька слів про ноосферу», що стала заповітом В.Вернадського, він наголосив, що «могутність людини пов'язана не 3 
матерією, а з іiі мозком, з їі розумом і спрямованою цим розумом іiі працею». I застеріг: "...еред людиною відкривається величезне майбутнє, якщо вона зрозуміє це й не буде використовувати свій розум i свою працю для самознищення" [7]. В умовах, коли глобальні виклики стають все загрозливішими для живого, інтелектуальне збагачення людства слід підпорядковувати утвердженню земного безсмертя.

М.Руденко - Герой України, дійсний член Української вільної академії наук, лауреат Національної премії імені Тараса Шевченка особливо масштабний як мислитель: філософ, космолог, економіст. Його онтологія сягає субстанційних засад вселенського та земного буття. Відкрита ним Сила Моносу є космологічною сталою, що закладена у підвалини самої світобудови. Світова економічна наука за Руденком - це наука, «від якої залежить життя на землі» [4, с. 481].

Це він відродив учення Ф. Кене про докорінну відмінність між продуктивним та безплідним класами суспільств. I розвинув парадигму доктора С. Подолинського - того, хто першим імплементував живе й неживе у світову економічну науку. Він продовжив учення академіка В. Вернадського, котрий вказав на керованість живого і неживого розумним.

...Внесок українських інтелектуалів у золотий фонд світової політичної та економічної науки $\epsilon$ рідкісним і потужним. Їхня розбудовча місія має бути розвинута: нам належить продовжити творення рятівного знання - науки, завдяки якій життя на планеті триватиме.

Надати класократії В.Липинського фундаментальну основу нині здатна спадщина подвижників національної економічної школи. Їхні здобутки являють собою питомо українське знання, що має статус рятівного. Поєднання цих національних здобутків здатне надати українству i людству інтелектуальну основу життєствердного окреслення політичної та економічної перспективи для власних i загальнолюдських нащадків.

\section{Список використаних джерел}

1. В'ячеслав Липинський та його доба: Книга друга. Наукове видання. - Упорядники: Т.Осташко, Ю.Терещенко. - Київ: Темпора, 2010. - 624 c.

2. Вінстон Черчилль: Вікіцитати - Вікіпедія [Електронний pecypc]. - Режим доступу: https://uk.m.wikiquote/ Вінстон Черчилль. 
3. В'ячеслав Липинський та його доба: Книга перша. Наукове видання. - Упорядники: Т.Осташко, Ю.Терещенко. - Київ: Темпора, 2010. - 560 с.

4. Руденко М. Енергія прогресу. Вибрані праці з економії, філософії і космології / М. Руденко. - К.: Кліо, 2015. - 680 с.

5. Подолинский С. Труд человека и его отношение к распределению энергии // Слово. - Апрель-май 1880. - С. 135-211.

6. Вернадский В.И. Очерки геохимии. - Львов: ВК «Арс», 2013. $-488 \mathrm{c}$.

7. Вернадський В.І. Кілька слів про ноосферу / У кн.: Філософія: Хрестоматія (від витоків до сьогодення). - К.: Знання, 2009. - С. 217225.

Ясько Ю.І., к.е.н., ст. викладач

Київський національний торговельно-економічний університет

\section{ЕВОЛЮЦЯ ТЕОРЕТИЧНИХ ПОГЛЯДІВ НА РОЛЬ ДЕРЖАВИ В ЕКОНОМЦЦ}

Розвиток економічних систем, якщо їх розглядати в багатогранному, а також односторонньому вимірах, відбувається під впливом державних і ринкових інституцій.

Державне втручання в економічні процеси може бути ефективним та виправданим лише за умови, якщо воно $є$ зваженим, а значить враховує функціональний розподіл між державою та ринком. Тому в економічній теорії часто постає питання співвідношення між державним регулюванням економіки i механізмом ринкового саморегулюванням. Вирішення даної проблеми значною мірою залежить від того, як розглядається сутність державного регулювання економіки.

Починаючи 3 кінця XV ст. науковці почали здійснювати дослідження проблематики необхідності та міри державного регулювання економіки. У процесі розвитку історії економічної думки відношення до ролі держави постійно змінювалося. До XVII ст. переважала думка про те, що держава повинна відігравати активну роль у розвитку торгівлі та промисловості. Опозиціонером данного твердження був Адам Сміт, у своїй праці «Дослідження про природу 
й причину багатства народів» (1776 р.) наголошував на обмеженій ролі держави в економічному розвитку країни [1]. А. Маршалл продовжив висловлювати схвалення переваг вільно-конкурентної структури ринку, розпочате А. Смітом. В своїх наукових дослідженнях А. Маршалл прийшов до висновку, що втручання держави можливе, але воно повинно бути мінімальним, інакше в економіці виникнуть диспропорції [2].

В сучасній економічний науці відбулося утвердження теорій, розроблених трьома провідними економічними школами, а саме: кейнсіанською, неокласичною та інституціональною, які відрізняються за своєю суттю. Слід відзначити, що фундатором теорії державного регулювання економіки є Джон Кейнс. У своїй основній науковій праці «Загальна теорія зайнятості, проценту і грошей» Кейнс довів, що держава має відігравати ключову роль та активно втручатися в економічні процеси [3]. На відміну від Дж. Кейнса, представники неокласичної економічної теорії, в більшості випадків, віддавали перевагу ринковому механізму саморегулювання економіки, що обмежує міру державного втручання в економіку. Також окремі положення щодо обмеження регулювання процесів економічного розвитку з боку держави передбачали й розробки представників інституціональної теорії. Вихідні засади інституціонального підходу набувають особливого значення для країн з перехідною економікою, оскільки розглядають економіку не як статичну систему, а як живий організм, що постійно модифікується.

Представники неокласичного синтезу наполягали на взаємодії державного регулювання з функціонуванням ринкових механізмів, що давало надію на вдосконалення інструментів регулювання економіки взагалі.

На реалізації проактивної державної прагматичної економічної політики наполягає Б. Данилишин, який зазначає, що будь-яка економічна політики, як на Заході, так і на Сході, є складним міксом кейнсіанських, монетаристських та інших заходів. Ніхто з економістів - практиків у світі не може сьогодні назвати себе ні чистим кейнсіанцем, ні монетаристом [4].

Слід зазначити, що сучасна економіка з точки зору ії глобалізації розглядається як синтез ринкового механізму та елементів державного регулювання, які постійно модифікуються під впливом розвитку світових господарських зв'язків і суспільства. Така модель закладена історично, адже чистої, нерегульованої економіки не існує, тому що об'єктивним є процес боротьби економічних суб'єктів за ресурси, товари й ринки. Об’єктивна реальність розвитку господарського 
механізму в ринковій економіці вимагає регулювання, так як нерегульований ринок не може бути ефективним - цей постулат доведений часом.

Я. Жаліло, який відстоює ідею економічного прагматизму, провідну роль відводить результативності економічних інструментів і зазначає, що «поділ на ліберально-ринкову i регуляторноадміністративну моделі економіки вже не $\epsilon$ актуальним. У чистому вигляді жоден із двох підходів не спрацьовує. Зростання економіки в цілому i добробуту окремого індивідуума можливе при синергії економічних інструментів [5].

Схожих принципів дотримується В. Панченко, який стверджує, що необхідно вийти за межі діалектики «лібералізм-протекціонізм», «держава-ринок». Старі протекціоністські інструменти відходять у минуле, на їхньому місці з'являються нові форми. Недарма в європейській практиці набуває вжитку термін «reregulation», що пояснює стан, коли дерегуляція, передбачаючи зняття обмежень, концентрується на запровадженні нових форм регуляції» [6].

Зважаючи на стрімкий розвиток глобалізаційних процесів сучасна економічна політика держави повинна бути не тільки більш активною, але й стабільною та послідовною. При цьому, іiі зміст не може визначатися лише ідеологічними засадами та принципами. Цілі та інструменти економічної політики повинні враховувати новітні тенденції суспільного розвитку.

Здійснення економічної політики держави потребує виходу на таку інституційну траєкторію, яка здатна забезпечити поступовий перехід до моделі, орієнтованої одночасно і на розвиток конкуренції, i на подолання обмежень ринку на основі цілеспрямованого форування відносин співпраці між державою, підприємницьким сектором та суспільством у цілому. Необхідність економічної політики держави обумовлена перш за все існуванням «неспроможності ринку» та потребою державного втручання у розвиток макроекономічних процесів [7, с. 145].

Різнобічні погляди науковців дають підстави стверджувати про беззаперечну роль держави в економіці, при цьому відображають необхідність пошуку модернізованих методів i інструментів державного регулювання, враховуючи новітні системні виклики.

Підсумовуючи результати аналізу наукової літератури, виявлено відсутність єдиної точки зору на роль та межі втручання держави в економіку. При дослідженні проблеми співвідношення державного втручання в економіку та ринковим саморегулюванням, заслуговує на увагу те, що раціональне державне регулювання економіки не 
суперечить ринковому механізму, а свідомо використовує його регулюючий потенціал, що в свою чергу, надає ринковим регуляторам можливість більш ефективно та цілеспрямовано впливати на соціально-економічний розвиток. В результаті це повинно сприяти досягненню цілей і пріоритетів, які визначила держава, мінімізуючи, при цьому, економічні і соціальні втрати.

\section{Список використаних джерел}

1. Сміт А. Добробут націй. Дослідження про природу та причини добробуту націй / А. Сміт; пер. $з$ англ. О. Васильєва [та ін.]. - К. : PortRoyal, 2001.

2. Маршалл А. Принципы экономической науки: в 3-х т. /

A. Маршалл. - М.: Бизнеском, 2010.

3. Кейнс Дж. М. Общая теория занятости, процента и денег / Дж. М. Кейнс; пер. с англ. Н. Н. Любимова. - М.: Гелиос АРВ, 2011.

4. Данилишин, Б. Про тактику економічного розвитку [Електронний ресурс] / Б. Данилишин // Лівий берег. - 2016. - 16 грудня. - Режим доступу: http://blogs.lb.ua/bogdan_danylysyn/ 353627.

5. Жаліло, Я. Про національні особливості економічного прагматизму [Текст] / Я. Жаліло // Дзеркало тижня. - 2016. - № 49.

6. Панченко, В. Операція «деіндустріалізація», або навіщо нам промисловий ренесанс [Текст] / В. Панченко, Н. Рєзнікова // Дзеркало тижня. -2016 . - № 9.

7. Уманців Ю. М. Еволюція ролі та функцій держави в економіці / Ю.М. Уманців, О. І. Міняйло // Економічний вісник університету. 2016. - Вип. 28 (1). - С. 140-148. 


\section{НАУКОВИЙ НАПРЯМ 2. ІНФОРМАЦЙНО-ЗНАННЕВА, МЕРЕЖЕВА, СЕРВІСНА ЕКОНОМІКА ХХI СТ.}

Волосович C.В., д. е. н., професор, Київський національний торговельноекономічний університет

\section{FINTЕСН ЯК ЧИННИК ЗРОСТАННЯ ФІНАНСОВӦ̈ ІНКЛЮЗИВНОСТІ}

В умовах посиленого розвитку економіки споживання активізується поширення фінансових технологій. FinTech - це інноваційні технології, які використовуються фінансовими інститутами, органами державного управління, торговельними організаціями для задоволення потреб споживачів фінансових, адміністративних послуг та товарів в умовах розвитку економіки споживання [1, с. 8]. Основними чинниками розвитку економіки споживання є:

- зростання частки середнього класу та багатих домогосподарств. Упродовж наступних 25 років чисельність середнього класу у глобальному масштабі зросте на 180\% [2];

- формування звички молодого покоління до здійснення витрат на тлі глобального зростання частки міленіалів у структурі населення та урбанізації. Так, до 2020 року у структурі глобальної робочої сили частка міленіалів становитиме 50\% [2];

- активізація е-комерції, що відбувається на тлі посилення глобалізаційних процесів та розвитку технологій;

- $\quad$ розвиток соціальних мереж;

- $\quad$ зростання популярності смартфонів, зокрема, у країнах, що розвиваються.

Водночас відбулася активізація трудової міграції, що обумовило пошук зручних та безпечних каналів міжнародних грошових переказів; доступних джерел фінансування малим і середнім бізнесом; нових можливостей вкладень своїх заощаджень приватними інвесторами; пропозицій інноваційних фінансових продуктів, що забезпечують потреби споживачів, технологічними компаніями. 
Еволюція FinTech передбачає виокремлення чотирьох етапів: зародження, активне впровадження, розширення, поширення. Етап зародження FinTech 1.0 (1866-1967 pp.) характеризується аналоговістю індустрії фінансових послуг, хоча вже спостерігався іiі зв'язок 3 технологіями. Фаза активного впровадження FinTech 2.0 (19682008 рр.) характеризувалася прогресом систем електронних платежів. Фаза розширення FinTech 3.0 (2009-2016 рр.) характеризувалася посиленим розвитком фінансових технологій у результаті впливу кризи 2008-2009 рр. При цьому відбулося зародження регулювання тих сегментів фінансового ринку, де застосовуються фінансові технології. Фаза поширення FinTech 4.0 (3 2017 р. по теперішній час) характеризується застосуванням інструментів фінансових технологій не лише на фінансового ринку, але і у сфері державних закупівель, адміністрування податків, соціального забезпечення.

Використання FinTech у фінансових системах є підгрунтям для забезпечення зростання фінансової інклюзивності. Фінансова інклюзивність нині відіграє все помітнішу роль у перетвореннях фінансового сектору. Її призначенням $є$ підтримання інклюзивного зростання, яке сприяє загальному економічному розвитку, підтримує соціальну згуртованість і зменшує нерівність у доходах [3]. Для бідних домогосподарств фінансова інклюзивність дає можливість здійснювати заощадження, що сприяє, з одного боку, їх фінансовій стабільності, зокрема, у разі втрати роботи та працездатності, а 3 іншого боку, створює підгрунтя для забезпечення залучення додаткових фінансових ресурсів господарюючими суб'єктами та фізичними особами.

Фінансова інклюзивність позитивно впливає на фінансову стабільність за рахунок зниження ризику проциклічності; істотне збільшення кількості дрібних вкладників збільшить як розмір, так i стабільність депозитної бази банків під час кризи [4]. Дослідження А. Ханніга та С. Янсена свідчать про те, що фінансові установи, клієнтами яких є люди з низьким рівнем доходу, як правило, виживають під час макроекономічних криз та підтримують місцеву економічну діяльність [5]. Заслуговує на увагу позиція Е. Прасада, який акцентує увагу на тому, що відсутність адекватного доступу до кредитів для малих та середніх підприємств та фізичних осіб-підприємців негативно впливає на загальне зростання зайнятості, оскільки їх діяльність цих суб'єктів господарювання $є$ трудомісткою [6]. Водночас фінансову інклюзивність можна розглядатися як бізнес-можливість, так і як соціальну відповідальність у разі залучення надання фінансових послуг мікрофінансовими установами [7]. Згідно із дослідженнями 
МакКінзі зростання фінансової інклюзивності до 2025 року зможе збільшити валовий внутрішній продукт усіх країн, що розвиваються, на 6\%, або до 3,75 трлн дол. США [8]. При цьому 67\% банківських регуляторів у 143 юрисдикціях, опитаних Світовим банком, визнають фінансову інклюзивність важливою та понад 50 країн офіційно затвердили досягнення цілі зростання фінансової інклюзивності [8].

Фінансові технології створили підгрунтя для виникнення стартапів, які швидше, дешевше та надійніше за допомогою інноваційних інструментів змогли задовольнити потреби споживачів фінансових послуг. Це вплинуло на подальші інституційні перетворення на ринку фінансових послуг, де традиційні фінансові посередники, зокрема, банки та страхові компанії почали модернізувати свої послуги із врахуванням здобутків FinTech. Проте нині фінансова інклюзивність вже вийшла за межі ринку фінансових послуг. Все частіше зустрічаються тези про інклюзивність щодо сплати податків, отримання соціальної допомоги, охорони здоров'я.

Таким чином, впровадження інструментів FinTech сприяє зростанню фінансової інклюзивності в умовах розвитку економіки споживання внаслідок спрощення доступу до фінансових послуг; поліпшення залучення продавцями фінансових послуг нових клієнтів; появи нових учасників ринку фінансових послуг; удосконалення методів ведення бухгалтерії; поліпшення взаємодії продавців фінансових послуг із регуляторами.

\section{Список використаних джерел}

1. Мазаракі А., Волосович С. FinTech у системі суспільних трансформацій//Вісник Київського національного торговельноекономічного університету. 2018. №2. С. 5-18

2. Security challenges in the evolving fintech landscape. URL: https://www.pwc.in/assets/pdfs/consulting/cyber-security/banking/securitychallenges-in-the-evolving-fintech-landscape.pdf

3. National Strategy for Financial Inclusion: Our platform to provide better lives. URL: http://www.afiglobal.org/sites/default/files/publications/bsp_speech.pdf

4. Khan, H. R. Financial inclusion and financial stability: are they two sides of the same coin? URL: https://www.bis.org/review/r111229f.pdf 5. Hannig, A. and Jansen S. Financial Inclusion and Financial Stability: Current Policy Issues. URL: https://www.adb.org/sites/default/files/publication/156114/adbi-wp259.pdf 
6. Eswar, S. Prasad. Financial Sector Regulation and Reforms in Emerging Markets: An Overview Working Paper No. 16428. URL: http://www.nber.org/papers/w16428

7. Dev, S.M. Financial inclusion: Issues and challenges. URL: https://www.scopus.com/record/display.uri?eid=2-s2.0-78349267737\& origin=inward\&txGid=a257f56c7c3395be4ec30084161aaa23

8. Rolf, A. Financial inclusion - Addressing the unbanked in developing countries.

URL: https://www.paymentscardsandmobile.com/financial-inclusion-addressingunbanked/

Гуменюк В.В.,

д. е. н., доцент

Івано-Франківський національний технічний університет нафти і газу

\section{ВЕКТОР ВІДПОВІДАЛЬНОГО РОЗВИТКУ В ДЕРЖАВНОМУ УПРАВЛІННІ ЕКОНОМІКОЮ ЗНАНЬ}

Знання належить до унікальних природних ресурсів і $є$ важливим суспільним надбанням, обсяги якого не зменшуються в процесі споживання. 3 результатами їх здобуття пов'язують зміни в суспільноекономічних системах, формування світоглядів цілих поколінь і епох, створення цінності, впровадження сучасних моделей i технологій державного управління.

Сучасна проблематика відповідального розвитку суспільства, що грунтується на концепції менеджменту знань, залишається недостатньо дослідженою, спостерігається недооцінювання іiі ролі й практичної значущості в контексті модернізації інституційного середовища, формування інтелектуальних систем та механізмів державного й регіонального управління економікою.

Сучасні ринкові відносини стали настільки індивідуалізованими, а відтак складними, що будь-які намагання їх системного впорядкування інструментами державного регулювання лише поглиблюють суперечності. «Ера державно-регуляторних адаптацій конкурентного ринку завершується» [1, с. 11]. В умовах конвергентного ринку - символічного обміну знаків та символів, 
якими у дійсності $є$ інформація та знання, найбільшої корисності набуває не рідкісність та дефіцитність, а поширеність [1, с. 12].

Будь-яка організація, що займається дослідженням та поширенням знань, керуючись базовими положеннями ДСТУ ISO 9001:2015 «Системи управління якістю. Вимоги» («Quality management systems - Requirements») [2], повинна:

- визначити знання, які необхідні для функціонування ії процесів на предмет досягнення відповідності послуг;

- забезпечити актуалізацію та доступність знань у потрібному обсязі для досягнення цілей організації;

- бути готовою реагувати на зміни, враховуючи свої поточні знання, можливості отримання додаткових знань і готовність до їх необхідного оновлення;

- здійснювати керівництво знаннями - складний, багатогранний, творчий процес управлінської діяльності 3 різним ступенем інтелектуалізації праці (від збору й опрацювання статистичних даних до створення інформаційних кластерів, які з'єднують складні ландшафти знань; побудови інтелектуальних систем управління, імунізації таких систем заради гарантування відповідального розвитку людини й економіки).

Однак навіть в умовах розвитку комунікаційних технологій сучасності, посилення впливу мас-медіа на суспільну свідомість очікувати на значний прогрес в контексті поширення знань не варто. К. Чіполло заявляв, що в будь-якій громаді питома вага осіб з недостатнім інтелектуальним розвитком для формування самодостатнього ефективного соціуму перевищує $3 / 4$ загальної чисельності спільноти [3, c.12], а за дослідженнями С. Коннора, з прогресом цивілізації розрив у зазначеному співвідношенні порушиться не на користь представників інтелектуальної еліти [4, с.12].

Для забезпечення відповідального розвитку суспільства процес поширення знань та інтелектуалізації мас в країні $\epsilon$ необхідною, але недостатньою умовою для досягнення позитивних зрушень відповідно до визначених стратегічних пріоритетів і цілей державного управління економікою. Досягнення ефекту поширення знань і зростання частки більш освічених працівників неможливо досягти ізольовано (рис.1). 


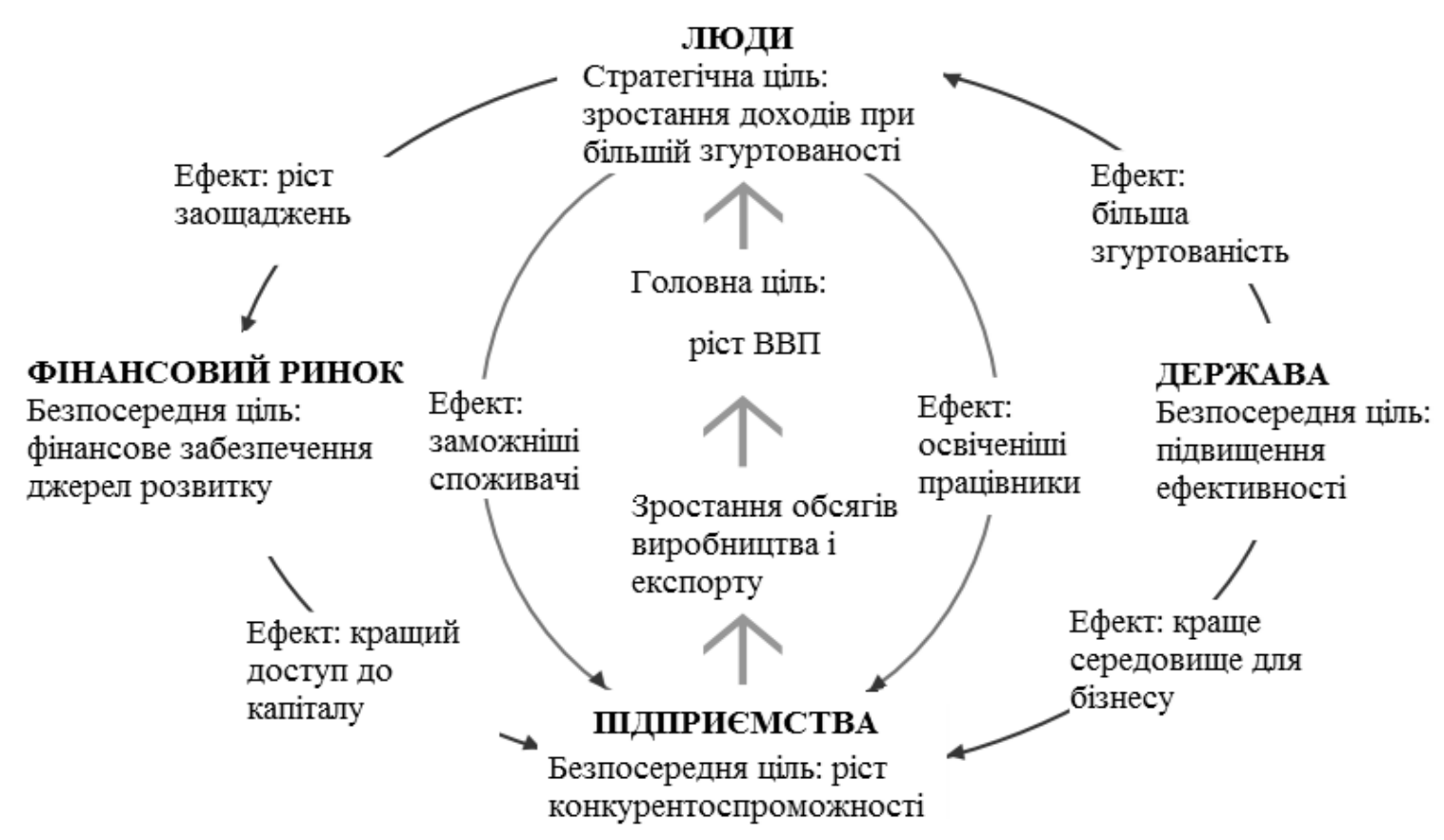

Рис. 1.Структурно-логічна схема реалізації стратегічної цілі відповідального розвитку [5. с.49]

Отже, економічна політика держави, що реалізується в системі координат відповідального розвитку спрямована на зростання доходів населення при більшій соціальній згуртованості, створення сприятливого середовища для бізнесу, дерегуляцію підприємництва, розкриття можливостей децентралізації, зміцнення інституту місцевого самоврядування, підвищення ефективності менеджменту знань.

\section{Список використаних джерел}

1. Гальчинський А.С. (2014). Конвергентний ринок методологія перспективи. Економіка України. № 1.

2. ДСТУ ISO 9001:2015. Системи управління якістю. Вимоги. (2016). Видання офіційне. Київ: ДП «УкрНДНЦ»

3. Cipolla C. (1987) The Basic Laws Of Human Stupidity: Whole Earth Review, Spring. URL: https://advanced.jhu.edu/wpcontent/uploads/2013/07/The-Basic-Laws-of-Human-Stupidity.pdf

4. Connor S. (2012). Human intelligence 'peaked thousands of years ago and we've been on an intellectual and emotional decline ever since': The Independent, November $12^{\text {th }}$. URL: https://www.independent.co. uk/news/science/human-intelligence-peaked-thousands-of-years-agoandweve-been-on-an-intellectual-and-emotional-8307101.html 
5. Strategia na Rzecz Odpowiedzialnego Rozwoju do roku 2020 (z perspektywądo 2030 r.) (2018). Ministerstwo Inwestycjii Rozwoju Serwispolskiego rządu. URL: https://www.gov.pl/web/inwestycjerozwoj/informacje-o-strategii-na-rzecz-odpowiedzialnego-rozwoju

Дідківська Л. В., к.е.н., науковий співробітник відділу економічної історії ДУ «Інститут економіки та прогнозування НАН України»

\section{ЕМІГРАЦІЯ УКРАЇЦВ В УМОВАХ СТАНОВЛЕННЯ ЕКОНОМІКИ ЗНАНЬ}

Людський інтелект, освітній потенціал стає капіталом, що визначає цінності та багатство сучасного суспільства в умовах становлення та розвитку інформаційно-знаннєвої економіки XXI ст. Розуміння таких світових трендів стимулює владу високорозвинених країн світу (США, Канада, країни СС та інші) приділяти особливу увагу розвитку освіти та науки, а також запроваджувати політику заохочення до міграції кваліфікованих фахівців і талановитої молоді 3 країн, що розвиваються. Водночас «відтік мізків» становить загрозу для країн-експортерів кваліфікованих та перспективних кадрів, оскільки втрачається інтелектуальний потенціал інноваційної модернізації власних економік. В умовах постіндустріального укладу суспільного розвитку така ситуація загрожує економічній безпеці країн, що розвиваються, так як довгострокове економічне зростання можливе сьогодні лише на основі інновацій і новітніх технологій. Ця проблема постала найбільш гостро і в Україні, адже за останні 25 років 3 країни виїхало понад 25 тис. наукових працівників [1]. 3 України мігрували передусім ті, хто складав ядро наукових колективів, мав великий потенціал до відтворення наукових шкіл, зокрема в галузях технічних, медичних, хіміко-біологічних та фізико-математичних наук, які сьогодні $\epsilon$ найбільш проривними у науковому прогресі. Такі незворотні втрати призвели до дисбалансів у науковій та освітній сферах, негативно вплинули на конкурентоспроможність вітчизняної економічної системи. Еміграції українських вчених сьогодні сприяють не тільки кризові політичні та економічні чинники всередині країни, 
але й багаторічна політика вимивання вітчизняної інтелектуальної еліти іншими державами.

Зрозуміло, що в умовах глобалізації спроби абсолютно припинити інтелектуальну міграцію позбавлені сенсу та безперечно зазнають фіаско. Адже наука не знає кордонів, завдяки академічній мобільності та міжнародній науково-технічній співпраці відбуваються наукові відкриття. Таким чином, циркуляція вчених у світі, «обмін мізків» лише примножує наукове знання, спрямовує людство до наукового прогресу. Незважаючи на деякі позитивні наслідки від мобільності наукових кадрів загалом, Україна, що має достатній науковий потенціал (44-е місце в Рейтингу глобальної конкурентоспроможності талантів за 2018 р. та 98-е місце у тому ж рейтингу щодо привабливості країни для висококваліфікованих кадрів [2]), ризикує стати експортером людського ресурсу для високорозвинених країн. Тим більше у короткостроковій перспективі навіть видається, що трудова міграція має позитивні наслідки: покращення добробуту українських родин за рахунок грошових переказів із-за кордону (середній щомісячний дохід трудових мігрантів у 2007 р. становив 817 дол. США, що майже в 3 рази вище середньої заробітної плати в Україні [3, с. 79]), скорочення рівня безробіття, надходження іноземної валюти в державу, включення вітчизняних вчених та висококваліфікованих працівників до міжнародних наукових та бізнесових проектів, передача мігрантами сучасних знань, навичок $\mathrm{i}$ технологій колишнім співвітчизникам, розвиток підприємництва [4], поширення інформації про країну походження у світі, посилення іiі авторитету завдяки активній громадській роботі діаспор.

Однак внаслідок інтелектуальної міграції у довгостроковій перспективі поглиблюється демографічна криза, зростає дефіцит кваліфікованих спеціалістів, незворотними виявляються втрати перспективної здібної молоді, для працездатного населення непосильним стає фіскальне навантаження, видатки 3 державного бюджету звужуються, що погіршує якість соціальних програм, втрачаються можливості для впровадження інновацій та високих технологій у виробництво, здатність до сталого економічного розвитку країни погіршується.

Посилення еміграційних настроїв українців-інтелектуалів пояснюється недостатнім рівнем фінансування вітчизняної науки, безнадійно застарілою інфраструктурою науково-дослідних установ НАН України, відсутністю суспільного та виробничого попиту на результати наукової праці (впродовж 2014-2016 рр. частка вітчизняних підприємств, які займались інноваційною діяльністю, становила 18,4\% 
[5]), низьким соціальним статусом вітчизняного науковця та кваліфікованого фахівця в країні, слабкою превентивною міграційною державною політикою в Україні. На противагу цьому український емігрант отримує за кордоном сприятливе середовище для акумуляції наукових знань, перспективи особистого кар'єрного росту, доступ до сучасних професійних знань і кваліфікаційних навичок світового рівня, високу якість життя у розвинених країнах світу.

3 метою збереження та примноження інтелектуального потенціалу України необхідно розробити та впровадити зважену превентивну державну міграційну політику. Передусім важливо визначити інноваційний розвиток як стратегічний пріоритет України, забезпечити державну підтримку нових інвестицій, венчурних фондів, сучасних інноваційних структур, створити спеціальні економічні зони та преференції для Research \& Development. Не менш дієвою у розв'язанні поставленої проблеми $є$ реформа навчальних та наукових установ, їх співпраця 3 новоствореними сучасними науковотехнологічними парками, лабораторіями та іншими інноваційними кластерами, результатом якої стане поява інноваційних наукомістких продуктів. Повернення престижу професії вченого, поваги до його творчої праці потребує підвищення рівня фінансування науки, створення сприятливих умов для науково-дослідної діяльності, гідного матеріального забезпечення вітчизняних інтелектуалів, включення талановитої молоді у процес формування прогресивної наукової спільноти в Україні. Причому найбільш результативним було б саме цільове фінансування суспільно значущих та креативних наукових розробок, виявлених на основі конкурсів та грантових програм. Підсилити рівень наукових розробок дозволить розширення міжнародного наукового співробітництва, інтеграція української науки в Європейський науковий простір, залучення вітчизняної інтелектуальної еліти до міжнародної науково-технологічної кооперації, що грунтується на співпраці світових наукових осередків.

\section{Список використаних джерел}

1. Ясинчук Л. Відтік мізків з України набирає сили. Експрес, 2018. Режим доступу :

https://expres.online/archive/main/2018/01/27/281999-vidtik-mizkivukrayiny-nabyraye-syly

2. Пивоваров Ю. Таланти їдуть з України. Як виправити ситуацію. НВ Бізнес, 2018. Режим доступу :

https://biz.nv.ua/ukr/experts/talanti-jidut-z-ukrajini-jak-vipravitisituatsiju-2467650.html 
3. Зовнішня трудова міграція населення України. К.: Український центр соціальних реформ, Держкомстат України, 2009.$120 \mathrm{c}$.

4. Developing Migration Policy. International Organization for Migration. Режим доступу:

www.iom.int

5. Державна служба статистики України. Режим доступу :

http://www.ukrstat.gov.ua

Лазебна I.B.,

к.е.н., доцент

Київський національний торговельно-

економічний університет

\section{ВПЛИВ МЕРЕЖЕВОЇ ЕКОНОМІКИ НА ЖИТТЯ СУСПІЛЬСТВА}

Кінець XX століття і перші роки XXI століття були захоплюючі часи. Підйом мережевих технологій як важливої форми комунікацій i торгівлі глибоко вплинув на те, як люди спілкуються і способи ведення бізнесу та організацій. Високошвидкісний зв'язок пов'язує технології та людей. Мережеві комп'ютери щоденно ділять трильйони символів інформації, що дозволяє нам знімати гроші з банкоматів у будь-якому місці в усьому світі, перевіряти погоду у віддалених місцях, і купувати квитки в будь-які місця, в будь-який час. Мережеві технології також мають різкий вплив на відносини між компаніями та їхніми клієнтами, постачальниками та працівниками. Телевізійні мережі, що використовують супутникові технології, дозволяють переглядати сотні каналів в будь-якій точці світу. Телефонні мережі, як дротові, так i бездротові, виробляють голосові та текстові комунікації в реальному часі, що можливо майже в будь-якій точці світу. Системи глобального позиціонування супутника (GPS) дозволяють здійснювати точну навігацію в будь-якому місці світу і часто зустрічаються сьогодні в приладових панелях автомобілів високого класу. І цей список включає лише деякі зі зростаючого числа мережевих додатків.

Bci мережі залежать від напрямів комп'ютеру. Фактично, комп'ютер є однією з найважливіших машин, що використовується у світі сьогодні - якщо не найважливішим. Комп'ютери обробляють 
необроблені дані в корисну інформацію, а потім надсилають цю інформацію по мережі іншим комп'ютерам.

Без комп'ютерів багато розвинутих світових заводів, транспортних систем та інших інфраструктурних компонентів швидко зупинилися. Ця проблема вимушеного масового оновлення світових комп'ютерних систем у підготовці до зміни з двадцятого на двадцять перше століття. Комп'ютер вважається одним 310 найважливіших винаходів останніх 2000 років, а також такі елементи, як окуляри та друкарський верстат.

Широко використовуваною формою мережевих технологій $\epsilon$ комп'ютерна мережа, яка складається з двох або більше підключених комп'ютерів. Такі комп'ютерні мережі формують нервову систему сучасних компаній i організацій, даючи змогу зацікавленим менеджерам, працівникам, постачальникам і клієнтам - взаємодіяти електронно. Найбільшою і найпоширенішою комп'ютерною мережею $\epsilon$ Інтернет, який з'єднує тисячі менших комп'ютерних мереж, тим самим зв'язуючи мільйони комп'ютерів у всьому світі [1]. Інтернет дає можливість спілкуватися по всьому світу і надає практично нескінченну кількість інформації, ніж іiі 500 мільйонів користувачів у всьому світі.

Велика частина діяльності здійснюється через Інтернет. Глобальні тенденції в Інтернеті представлено у табл. 1.

Таблиця 1

Загальне користування Інтернетом [2, 3]

\begin{tabular}{|c|c|c|c|c|}
\hline $\begin{array}{c}\text { Кількість } \\
\text { активних } \\
\text { інтернет- } \\
\text { користувачів }\end{array}$ & $\begin{array}{c}\text { Кількість } \\
\text { користувачів } \\
\text { соціальних } \\
\text { мереж }\end{array}$ & $\begin{array}{c}\text { Кількість } \\
\text { веб-сайтів }\end{array}$ & $\begin{array}{c}\text { Кількість } \\
\text { мобільних } \\
\text { користувачів }\end{array}$ & $\begin{array}{c}\text { Кількість } \\
\text { мобільних } \\
\text { користувачів } \\
\text { соціальних } \\
\text { мереж }\end{array}$ \\
\hline \multicolumn{5}{|c|}{ Світ } \\
\hline 4,021 млрд & 3,196 млрд & 1,24 млрд & 5,135 млрд & 2,985 млрд \\
\hline \multicolumn{5}{|c|}{ Україна } \\
\hline 25,59 млн & 13,00 млн & 65,63 млн & 9,50 млн \\
\hline
\end{tabular}

На додаток до Інтернету, інші мережі починають мати значні наслідки для нас. Наприклад, мережі мобільних телефонів ростуть дуже швидко, як і нові програми для них. Поточна тенденція полягає в поєднанні мобільних телефонів з Інтернет, щоб забезпечити найкращі можливості обох, тобто бездротового голосового зв'язку і доступ до практично необмеженої кількості інформації. Сьогодні практично неможливо знайти компанію будь-якого розміру в розвинених країнах, 
що не має внутрішньої комп'ютерної мережі, що дозволяє співробітникам обмінюватися інформацією та ідеями.

Інтернет зробив можливим для людей знайти інформацію про придбання товарів, перевірити функції та ціни, перш ніж фактично придбати товар, поспілкуватися з друзями та родичами за допомогою електронної пошти або обміну миттєвими повідомленнями, приєднатися до групи чату, обговорюючи різні теми, прослуховувати віддалені радіостанції у прямому ефірі, купувати та продавати товари на інтернет-аукціоні та ін.

Комп'ютерні мережі - це не просто новий спосіб обробки бізнесоперацій або пошук інформації; вони також забезпечують кращий спосіб ведення бізнесу. Комп'ютерні мережі є основою нового типу економіки - мережевої економіки. За 200 років люди жили і працювали в промисловій економіці, яка була побудована на існуванні капіталу, у вигляді заводів, машин, i праці, у формі працівників. Навпаки, мережева економіка об'єднує посилені, трансформовані або нові економічні відносини, засновані на комп'ютерах, зв'язності та людських знаннях [4].

Основним результатом руху до мережевої економіки $\epsilon$ те, що організації всіх типів повинні навчитися використовувати нову комбінацію комп'ютерів, зв'язок, а людські знання залишаються конкурентоспроможними і виживають. Організації більше не можуть сподіватися зробити те, що вони робили роками; замість цього вони повинні змінюватись або ризикувати. Суть мережевої економіки - це не просто зміна; це зміна з прискореною швидкістю. Компанії повинні постійно перевіряти своє середовище на нові способи обслуговування своїх клієнтів або ж зіткнутися з ними в перспективі вважаючи, що інша компанія замість цього буде обслуговувати своїх клієнтів. Ця вимога може означати кардинальну зміну способу ведення бізнесу цих компаній і фактично може підштовхнути компанії до переходу на нові підприємства.

Підгрунтям мережевої економіки $\epsilon$ цифрова економіка (комп’ютерна платформа для інформаційного ресурсу, інформаційнокомунікативне середовище). Економіка знань продукує інтелектуальний продукт і високі технології. Фактором виробництва стає інформація і знання [5]. Хоча інформаційні технологї можуть рухати кордон між мовчазним і кодифікованим знанням, вони є також зростаючою важливістю набуття широкого спектру навичок або видів знань. При появі інформаційного суспільства, велика i зростаюча частка робочої сили займається обробкою інформації на відміну від більш відчутних факторів виробництва. Комп'ютерна грамотність і 
доступ до мережевих об'єктів мають тенденцію стати більш важливим, ніж грамотність у традиційному розумінні. Хоча економіка, заснована на знаннях впливає на збільшення використання інформаційних технологій, не є синонімом інформації суспільства.

Оскільки доступ до інформації стає легшим і менш дорогим, навички та компетенції, пов'язані 3 вибором i ефективним використанням інформації стають більш важливими. Мовчазні знання у формі навичок необхідні для обробки кодифікованих знань більш важливі, ніж будь-коли на ринках праці. Кодифіковані знання можуть розглядатися як матеріал, який необхідно трансформувати, і мовчазні знання, зокрема, ноу-хау, як інструмент для обробки цього матеріалу.

Накопичення мовчазних знань, необхідних для отримання максимальної вигоди від кодифікованого знання інформаційних технологій можуть бути зроблені тільки за допомогою навчання. Без інвестицій, орієнтованих на кодифікований і мовчазний розвиток навичок, інформаційні обмеження можуть бути важливим чинником, що принижує ефективність розподілу ринкової економіки. Цей процес навчання більше, ніж просто набуття формальної освіти. У економіці, що базується на знаннях «навчання за допомогою» $є$ надзвичайно важливим. Фундаментальним аспектом навчання $є$ трансформація мовчазного кодифікованого знання i рух назад до практики, де розвиваються нові види мовчазних знань.

Навчання в неформальній обстановці, що стає все більш можливим завдяки інформаційним технологіям частішає. Фірми самі стикаються 3 необхідністю стати навчальними організаціями, які постійно адаптуються до менеджменту, організацій та навичок 3 урахуванням нових технологій. Вони також приєднані до мереж, де інтерактивне навчання залучає виробників i користувачів до експериментів і обміну інформацією, що є рушієм інновацій.

Економіка, що базується на знаннях, надає великого значення поширенню та використанню інформації та знанню, а також його створення. Детермінанти успіху підприємств і національних економік в цілому, все більше залежать від їх ефективності у зборі та використанні знань. Стратегічні ноу-хау та компетентність розробляються інтерактивно та спільно в рамках підгруп та мереж, де знають - хто є значним. Економіка стає ієрархією мереж, керованої прискоренням у швидкості зміни і швидкості навчання. Створене мережеве суспільство, де $\epsilon$ можливість і здатність отримати доступ i приєднатися до інтенсивних відносин знань і навчання, визначає соціально-економічне становище окремих осіб і фірм. Мережева 
характеристика економіки, що базується на знаннях, виникла iз змінами в лінійній моделі інновацій (рис. 1).

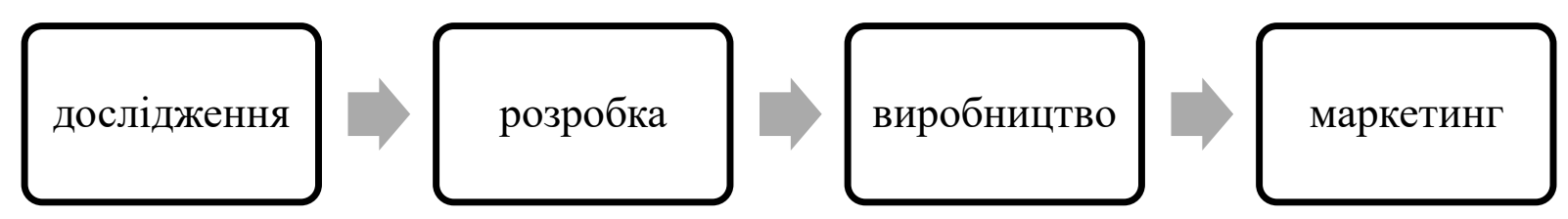

Рис. 1. Лінійна модель інновацій

Традиційна теорія вважала, що інновація $є$ процесом відкриття, яка протікає по фіксованій і лінійній послідовності фаз. 3 цієї точки зору інновація починається з нового наукового дослідження, прогресує послідовно через етапи розробки продукту, виробництва і маркетинг і закінчується успішним продажем нових продуктів, процесів і послуг. Це зараз визнали, що ідеї щодо інновацій можуть походити з багатьох джерел, включаючи нове виробництво, можливості та визнання потреб ринку. Інновації можуть приймати багато форм, включаючи додаткові удосконалення існуючих продуктів, застосування технологій на нових ринках i використання нових технологій для обслуговування існуючого ринку. І процес не $є$ повністю лінійним. Інновації вимагають значних значень спілкування між різними суб'єктами - фірмами, лабораторіями, академічними установами та споживачами як зворотний зв'язок між наукою, технікою, розробкою продукції, виробництвом і збутом.

Оскільки нові технології створюються швидше і швидше - і як вони приймаються на рекордних швидкостях за ринками, справедливо сказати, що майбутнє може прийти з шаленою швидкістю.

\section{Список використаних джерел}

1. The great transformer: the impact of the Internet on economic growth and prosperity [Електронний ресурс]. - Режим доступу: https://www.mckinsey.com/ /media/McKinsey/Industries/High\%20Tech/ Our\%20Insights/The\%20great\%20transformer/MGI_Impact_of_Internet_o n_economic growth.ashx

2. У 2018 інтернет-користувачів стало 4 млрд, 3 них понад 3 млрд користуються соцмережами - дослідження [Електронний ресурс]. Режим доступу: https://hromadske.ua/posts/u-2018-internetkoristuvachiv-stalo-4-mlrd-z-nih-ponad-3-mlrd-koristuyutsyasocmerezhami-doslidzhennya 
3. Інтернет-тенденції 2019 року. Статистика та факти в США та в усьому світі [Електронний ресурс]. - Режим доступу: https://uk.vpnmentor.com/blog

4. How the networked economy will change your life [Електронний pecypc]. Режим доступу: https://www.weforum.org/agenda/2015/01/how-the-networked-economywill-change-your-life/

5. Топішко Н., Топішко I., Галецька Т. Мережева економіка як форма соціально-економічної організації в глобальних координатах. Наукові записки Національного університету «Острозька академія». Серія «Економіка» : науковий журнал. 2018. №8(36). С. 33-38.

Левандівський О.Т.., к. е. н., доцент ДВНЗ «Прикарпатський національний університет імені Василя Стефаника»

Казюка Н.П., к.е.н., провідний інженер Івано-Франківський національний університет нафти і газу

\section{МОДЕЛЬ ІНВЕСТУВАННЯ АГРАРНОГО СЕКТОРУ}

Для здійснення інвестиційної діяльності в аграрному секторі необхідно розробити модель, яка б враховувала максимум факторів, що визначають суть процесу інвестування сільськогосподарських підприємств. На основі аналізу вітчизняних та зарубіжних досліджень вважаємо за доцільне запропонувати чотирьохрівневу модель.

Основними блоками першого рівня є: інвестиційний клімат, економічний механізм інвестування та особливості ведення сільського господарства.

Інвестиційний клімат - середовище, де відбуваються процеси інвестування. Воно формується під впливом сукупності політичних, соціально-економічних, фінансових, соціокультурних, організаційноправових та географічних чинників, які приваблюють або відштовхують інвесторів.

Наступним блоком $\epsilon$ економічний механізм інвестиційної діяльності в аграрному секторі, що будується 3 урахуванням специфічних особливостей галузі: 
- засобом сільськогосподарського виробництва є земля. Земля, виступаючи основним ресурсом сільського господарства, вимагає раціонального використання, підтримки рівня іï економічної родючості, відшкодування не тільки використаних поживних речовин грунту, а і покращення якісних показників (вмісту гумусу, зниження рівня кислотності, покращення стану водно-повітряного режиму) шляхом вапнування, меліорації, гіпсування, внесення органічних та мінеральних добрив, що вимагає значних інвестицій. Крім того, різниця в родючості грунтів, місцезнаходженні господарств по відношенню до пунктів збуту продукції створюють неоднакові умови для одержання доходів від інвестування;

- сезонність виробництва впливає на організацію виробничих процесів, ефективне використання техніки, трудових ресурсів i, нарешті, інвестицій;

- процес економічного відтворення пов'язаний з природним процесом відтворення. В якості необхідних елементів тут виступають живі організми (тварини, рослини, мікроорганізми), а також грунт, родючість якого пов'язана з біологічними факторами. Внаслідок чого, при розробці механізму інвестиційної діяльності виникає необхідність врахування закономірностей їх розвитку;

- важливою особливістю сільського господарства $\epsilon$ те, що створена продукція приймає безпосередню участь в подальшому процесі виробництва. Частина зерна, картоплі та інших культур використовується на насіння, корм тваринам;

- значна частина поголів'я спрямовується на відтворення i розширення стада худоби. В зв'язку 3 цим необхідні додаткові вкладення для будівництва приміщень і об'єктів виробничого призначення;

- розміщення у просторі сільськогосподарського виробництва обумовлює великий обсяг перевезень різних вантажів - урожаю сільськогосподарських культур, кормів, палива, мастильних матеріалів, добрив, запасних частин, що викликає підвищену потребу сільського господарства в енергетичних ресурсах i додаткових засобах виробництва, для придбання яких потрібні значні обсяги інвестицій;

- в залежності від агрокліматичних факторів та метеорологічних умов урожайність може коливатися. Це необхідно врахувати і в інвестиційній політиці по відношенню до розвитку потужностей зберігання і переробки. Вкладення в запасні потужності окупляться тією частиною врожаю, яка буде в них збережена в сприятливі для великого врожаю роки; 
- для забезпечення тривалого і економного використання машин на протязі року, поряд з їх спеціалізацією стосовно до особливостей сільськогосподарських культур i зон, необхідно враховувати їх універсалізацію, що відобразиться на обсягах інвестицій при придбанні необхідної сільськогосподарської техніки;

- інвестиційна діяльність в аграрному секторі економіки тісно пов'язана 3 особливостями сільськогосподарських ринків. Ринок сільськогосподарської продукції вважається типовим представником ринку досконалої конкуренції, але насправді це не так. Ці ринки звичайно збалансовані, та при підвищенні попиту на продукцію сільськогосподарського виробництва вони не мають можливості швидко відреагувати на зростання цін і збільшити виробництво продукції.

В цих умовах інвестиції в аграрний сектор вимагають додаткової уваги, в тому числі і державної підтримки. При падінні попиту на продукцію сільгосппідприємство не в змозі швидко пристосуватися до нових умов, наприклад, йому складно зразу скоротити площі під сільськогосподарськими культурами, якщо вже проведені посівні роботи; істотно зменшити виробництво молока та м'яса без скорочення поголів'я худоби. Все це вимагає певного часу. Галузь відрізняється низькою маневреністю інвестицій, а, звідси, і не досить високою рентабельністю.

На другому етапі формування інвестиційного процесу необхідно визначити джерела інвестицій та учасників (суб'єктів) інвестування. Вони поділяються на власні, позичкові, залучені та бюджетні [1].

Власні фінансові ресурси - це амортизаційні відрахування, прибуток після сплати податків, продаж частини активів, а також грошові надходження від реалізації вибракуваної худоби з основного стада, виручка від ліквідації основних засобів, страхові відшкодування за основні засоби, вибулі внаслідок стихійного лиха.

Позичкові фінансові засоби - це кредити банків, інвестиційних інститутів і бюджетних організацій, випуск боргових цінних паперів. Темпи приросту кредитного портфеля для агросектору протягом останніх двох років перевищували 20\%. Рівень дефолтів серед позичальників аграрного сектору - у 1,5 рази менший, ніж у торгівлі наступному за дисципліною обслуговування кредитів [2].

Залучені фінансові ресурси - це кошти від продажу інвестиційних цінних паперів, пайових та інших внесків фізичних і юридичних осіб, венчурний капітал.

Бюджетні джерела інвестиційної діяльності - це асигнування, які здійснюються державою частково або повністю для реалізації 
важливих капіталомістких проектів у розвиток аграрного сектора, наприклад у меліорацію.

Загальний обсяг видатків на АПК та надання кредитів Мінагрополітики у 2019 році складає 15 млрд грн. Фінансування 3 державного бюджету - 6,9 млрд грн., в тому числі по загальному фонду - 5,9 млрд грн. [3].

Крім названих джерел інвестиційної діяльності підприємства можуть використовувати благодійні внески, пожертвування інших фізичних та юридичних осіб.

Третім етапом формування інвестиційного процесу $\epsilon$ встановлення напрямів використання інвестицій і визначення об'єктів інвестиційної діяльності.

Напрямами використання інвестицій можуть бути соціальноекономічні програми, інноваційні проекти, виробнича діяльність, інфраструктура, охорона і відтворення земельних ресурсів, проблеми екології.

Об’єктами інвестиційної діяльності відповідно до Закону України “Про інвестиційну діяльність" можуть бути основні фонди і оборотні кошти в галузі, цінні папери, цільові грошові вклади, науково-технічна продукція, інтелектуальні цінності, об'єкти власності, а також майнові права.

Ефективність вкладення капіталу в той чи інший інвестиційний проект в умовах ринкової економіки є вирішальною умовою розвитку сільськогосподарських підприємств. Тому інвестиції в аграрному секторі слід вкладати в найбільш надійні та перспективні проекти, які зможуть забезпечити одержання надійних прибутків. Прийняття підприємствами рішень про інвестування проекту обумовлюється цілями, які воно ставить перед собою.

До головних інвестиційних цілей можна віднести: отримання регулярного поточного доходу, захист інвестицій від інфляції, збереження та приріст капіталу, участь в управлінні підприємством за рахунок придбання великих або блокуючих пакетів акцій, довгострокове надійне розміщення коштів під вигідні відсотки, швидкий приріст майна власного підприємства.

Оптимальний вибір шляхів досягнення мети забезпечує раціональне використання коштів, спрямованих на інвестування.

Таким чином, центральною ланкою інвестиційного процесу в аграрному секторі є пошук джерел інвестицій з одного боку, і напрямів інвестування 3 іншого. Це, насамперед, стосується інвестиційної політики кожного господарюючого суб’єкту. 


\section{Список використаних джерел}

1. Андрійчук В. Г. Економіка агропромислового комплексу: підручник / В. Г. Андрійчук. [Електронний ресурс]. - Режим доступу: https://pidruchniki.com/75513/ agropromislovist/ dzherela finansuvannya investitsiy

2. Ваврищук В. В. Гроші - в землю: як пожвавити кредитування аграрного сектору в Україні? / В. В. Ваврищук. [Електронний peсурс]. - Режим доступу: https://agravery.com/ uk/posts/ author/ show?slug=grosi-v-zemlu-ak-pozvaviti-kredituvanna-agrarnogo sektoru -v-ukraini

3. АПК - Бюджет 2019 [Електронний ресурс]. - Режим доступу: https://budget2019.info/priority/4

Ліпін М.В., к.ф.н., доцент, Київський національний торговельноекономічний університет

\section{ЗНАЧЕННЯ ТВОЧОСТІ У «КРЕАТИВНІЙ ЕКОНОМІЦઁ}

Впродовж минулого століття відбулось руйнування усіх великих «універсалій» класичної культури. Вони впали одна за одною, усе було піддано нігілістичному сумніву та критичному нищенню. Внаслідок цього до останнього часу можливість і джерело впорядкування різноманітних кризових явищ вбачались у просторі економіки. Саме на неї покладався обов'язок бути рушійною силою соціальної модернізації. Особливо сильно ці сподівання проявилися на теренах пострадянського суспільства, в межах якого відбулася абсолютизація економіки [1, с. 9]. Зрозуміло, що паралельно повинна була відбутись абсолютизація економічних способів мислення та поведінки. В результаті світоглядних деформацій модель людини була редукована до виміру homo economicus, життя людини до ситуації прийняття економічних рішень, творчість до тих форм які могли бути успішно комерціалізованими, тобто до інновації, креативності.

Важливо підкреслити, що ситуація nост- породжується саме логікою розвитку капіталізму зрозумілого як ринкова система, котра впорядковує сучасний соціальний устрій. Так, наприклад, на думку $\Phi$. 
Джеймісона, постмодернізм $є$ породженням транснаціонального капіталізму, він відтворює і зміцнює логіку «суспільства споживання». «Я вважаю, - писав американський вчений, - що виникнення постмодернізму тісно пов'язане з виникненням цього нового етапу, у пізньому, споживчому або багатонаціональному капіталізмі. Я вважаю також, що формальні риси постмодернізму багато в чому виражають внутрішню логіку цієї соціальної системи» [2, с. 293]. Іншими словами, ринкова система, яка народжується разом з епохою модерну, в ситуації nост- досягає свого апогею. Вона втілює в собі те спільне, що поєднує модерн та постмодерн у єдине ціле і дозволяє побачити у їх конфронтації та протистоянні трансформацію одного і того ж самого начала.

В контексті цих міркувань важливою є думка С. Леша та Дж. Уррі згідно якої сучасна стадія розвитку західного суспільства трактується як «дезорганізований капіталізм»[3]. Справа у тому, що його головною особливістю $є$ зростаюча швидкість, котра долає простір. Зникає не тільки розуміння але й відчуття місця, розташування у певній точці простору. Разом із дезорганізацією відбувається дематеріалізація оточуючого світу. Немов би підкорюючись законам фізики речі в контексті соціального прискорення, розпорошуються на інформаційні одиниці знаків. Це капіталістичне господарство можна визначати одночасно і як «постфордиське», і як «постмодерніське» [3, с. 50]. Прискорення знищує як світ речей-товарів, так і світ смислів. «Товарообіг відбувається все швидше, і об'єкти, а також культурні артефакти перетворюються на одноразові товари i поступово позбавляються смислу» [3, с. 51]. У вигляді компенсації відсутності смислу «дезорганізований капіталізм» пропонує надлишок виробництва знаків. Інформаційні потоки настільки перенасичені ними, що людина втрачає здатність сприймати їх.

Подібна ситуація унеможливлює співвіднесення знаку з тією реальністю, яку він позначає. Швидкість життя в сучасному соціумі передбачає ефективне функціонування за умови пристосування до мінливого циркуляції сфери знаків. «Дезорганізований капіталізм дезорганізує i все навколо»[3, с. 51]. Висловлюючись інакше, «дезорганізована економіка» дезорганізує і культуру, освіту ma творчість.

Окрім цього, формування ринкової економіки відбувається при одночасній переорієнтації людської уваги з якісних на кількісні виміри світу. Ринок оперує перш за все кількісними параметрами. «Соціальна взаємодія між людьми з приводу виробництва, розподілу і обміну набуває специфічної, безпосередньо кількісної форми, а саме форми 
цін, які репрезентують пропорції в обміні і виробництві»[4, с. 83]. Наслідком цього процесу постає зникнення якісної відмінності між різними речами та людьми. Властиве економіці абстрактне відношення дозволяє втягнути у власну орбіту що завгодно, одночасно нівелюючи особистісне начало.

Подібне нівелювання якісних особливостей світу призводить до редукції творчості до креативності. Цей процес обумовлений специфікою сучасного економічного розвитку, коли творчість постає одним 3 найважливіших ресурсів. Втім ототожнення творчого та креативного відношення до світу призводить до суттєвих зрушень у освітній практиці. Вагомою відмінністю творчості від креативності $\epsilon$ те, що одна з них, умовно кажучи, $є$ способом реалізації універсальних потенцій буття, а друга - суб'єктивних приватних інтересів. В творчості відбувається приведення людини у відповідність 3 універсальними засадами світу. Натомість в креативності відбувається приведення світу у відповідність до індивідуальних або групових потреб. Творчість прислуховується до логосу світу, натомість креативність нав'язує йому свій голос. Зосередженість на всезагальних формах розвитку людини і світу надає творчості можливість бути дотичною до вічності. Через це вона постає своєрідною практикою втечі від смерті, практикою оволодіння часом. Для креативності важливим $є$ результат, час існування якого досить обмежений. Вона зорієнтована на скороминущу мить, а не на вічність.

Необхідно зважати, що творчість не існує у вигляді певного інструменту, що може бути відділений від людини та тих суспільних відносин, в яких вона перебуває. Присутність творчості безпосередньо репрезентована у способах буття людини і іï відносинах з іншими людьми. Тому творчість обов'язково супроводжується зміною людини i суспільства. В такому ракурсі заклики до творчості одночасно $\epsilon$ закликами до самотрансформації людини і суспільства. Зрозуміло, що дійсне бажання і готовність зробити творчість повсякденним способом нашої життєдіяльності обертається відкритістю до постійного самооновлення, котре може вступати у суперечність щодо сталих, наявних форм соціальної системи. Проблема у тому, що будь-який наявний соціальний порядок прагне видати себе за природний, вічний та незмінний. Отже, збереження наявного соціально-економічного режиму існування передбачає приборкання творчості, виведення ii за межі повсякденного існування індивідів. В таких умовах творчість локалізується у обмежених сферах соціально-економічної системи та допускається у контрольованих формах. 
Сучасна міфологія креативності відповідає зазначеній меті. Перелічимо деякі міфи, що утвердилися в наш час щодо творчості. Почнемо 3 того, що творчість розглядається як здібність окремого індивідуума. Цей міф можна визначити як міф про творчість як індивідуальну здібність. На противагу цьому необхідно зазначити, що будь-який індивід виникає та існує як суспільна істота. Творчість $\epsilon$ інтерсуб'єктивною, вона є міжособистісною справою, тобто співтворчістю [5].

Іншим міфом, що логічно витікає з попереднього, постає міф про винятковість творчих здібностей. Уявлення про те, що творчість доля небагатьох, вкорінене в наявному розподілі праці, що бере свій початок $з$ часів рабовласництва. 3 огляду на зазначене стає зрозумілим, чому також поширеним є міфр про анормальність, девіантність mворчості. Якщо існуюча соціальна система зацікавлена у відтворенні нетворчих, репродуктивних способів повсякденного існування людини, тоді зрозуміло, що творче начало буде сприйматись як таке, що виходить за межі норми.

Необхідно розглянути творчість як норму людського буття, причому не як встановлену навколишніми умовами існування норму, не конвенціональну норму, а як адекватний спосіб людського розвитку. Розмова про творчість неминуче виводить нас на проблему розвитку людської особистості. Значущість творчості полягає у тому, що в ній відбувається збереження $i$ розширення всезагальних способів людського існування.

Наступним поширеним міфом про творчість $є$ впевненість у тому, що творчість - ие обов'язково створення нового. Цей міф містить ще одне припущення, котре необхідно прояснити. Якщо під час визначення творчості основна увага зосереджується на створенні нового, тоді творчість сприймається у вигляді результату, а значить як засіб, а не самоиіль.

Ще один розповсюджений погляд на творчість пов'язаний з тим, що iï уявляють як одну з багатьох здібностей людини. В такому випадку творчість розглядається поряд 3 інтелектуальними та академічними здібностями, соціальними, художніми або духовними. Особливо яскраво дана диференціація простежується у розрізнені творчості та мислення, креативності та інтелекту. Відповідно мислення, наприклад, може тлумачитися нетворчим, а творчість бездумною.

Освіта як транслятор наявного стану речей існує не як продукування творчого начала, а скоріше як відтворення та фіксування репродуктивних функцій людини. Світ в цілому, та економіка зокрема, 
вимагають творчої людини, а комерціалізована освіта спрямована на підготовку «людини корисної», тобто на формування наперед заданої кількості та конфігурації корисних якостей. Якщо творчість орієнтована на самовизначення, то «людина корисна» орієнтована на старанне відтворення запрограмованих інструкцій та алгоритмів. Або, говорячи інакше, якщо творчість співпричетна свободі, то «людина функція» - автоматизму та догматизму. Без творчого начала освітній простір приречений випускати старанних виконавців хоча майбутнє вимагає творців. Саме тому, «подальший розвиток вимагає освітньої бази, яку можуть собі дозволити далеко не всі країни, що розвиваються. На даний момент ії швидке створення є наріжним каменем економічного розвитку» [6, с. 24].

Освіта повинна орієнтуватися на розвиток творчої здібності людини, а це в свою чергу, із необхідністю призведе до актуалізації особистісного начала. Потреби економічного розвитку вже сьогодні обумовлюють необхідність «перекваліфікації» старанного виконавця, ефективної найманої робочої сили у творчу людину. Важливим прикладом усвідомлення цього є праця П. Друкера «They're not employees, they're people» (Вони - не наймані працівники, вони - люди) [7]. Те, про що вже давно говорить філософія освіти, стає реалією ринку праці. Отже, ми опиняємося перед наступним вибором: творча здібність, універсальний розум «або професійний кретинізм - ця антитеза очевидна сьогодні будь-якому споживачу розуму» [8, с. 196].

\section{Список використаних джерел}

1. Базилевич В.Д. Метафізика економіки / В.Д. Базилевич, В.В. Ільїн. - К. Знання, 2007. - 718 с.

2. Джеймисон Ф. Постмодернизм, или культурная логикапозднего капитализма / Ф. Джеймисон // Современная литературная теория. Антология; сост. И.В. Кабанова. - М.: Флинта: Наука, 2004. - C. 272-291.

3. Лэш С. Хозяйства знаков и пространства. Введение / С. Лэш, Дж. Урри // Экономическая социология, 2008. - Т. 9. - № 4. - Режим доступу:

http://ecsoc.hse.ru/data/654/589/1234/8ecsoc t9 n 4 .pdf\#page=7

4. Фоули Д. Математический формализм и политэкономическое содержание / Д. Фоули // Вопросы экономики, 2012. - № 7. - С. $82-$ 95.

5. Бахтин М. Эстетика словесного творчества / М.Бахтин. - М.: Художественная литература, 1979. - 412 с. 
6. Друкер П. Менеджмент и работа мира / П. Друкер // Мысль, 2008. - №1 - С. 24-37.

7. Дракер П. Они - не наемные рабочие, они - люди / П. Дракер // Российский журнал менеджмента, 2004. - Т.2. - №2 - С. 155166.

8. Лобастов Г. В. Философско-педагогические этюды / В. Лобастов. - М. : Микрон-принт, 2003. - 329 с.

Марченко О. С., д.е.н., професор Національний юридичний університет імені Ярослава Мудрого

\section{БІЗНЕС-КОНСАЛТИНГ У СТРУКТУРІ СЕРВІСНӦ̈ ЕКОНОМІКИ: ГОЛОВНІ ХАРАКТЕРИСТИКИ ТА ФУНКЦЇ̈}

Бізнес-консалтинг як сукупність ділових послуг є складовою сучасної сервісної економіки, має загальні риси сервісної діяльності та особливості, обумовлені змістом та принципами консалтингового обслуговування суб'єктів господарювання.

Обгрунтування змісту, організаційно-економічного механізму, функцій та ролі бізнес-консалтингу у забезпеченні постіндустріальних економічних трансформацій $\epsilon$ важливим напрямом наукових досліджень сервісної економіки. Але багатоаспектний зміст та закономірності розвитку цього сектору сервісної економіки, що у теперішній час стрімко набуває суспільного визнання як дієвий чинник інтелектуалізації та інноваційної активності бізнесу, ще не є об'єктом системного наукового аналізу.

По-перше, бізнес-консалтинг як урегульована контрактом підприємницька діяльність фахівців 3 різних галузей знань та їх організацій з сприяння суб'єктам господарювання у вирішенні бізнеспроблем з метою підвищення їх ефективності та отримання прибутку, сполучає характеристики інтелектуальної (професійної), сервісної та підприємницької діяльності. Головним ресурсом, конкурентною перевагою та обмежуючим чинником бізнес-консалтингу є знання та досвід консультантів, тобто його інтелектуальний (професіональний) вектор. Підприємницький вектор бізнес-консалтингу спрямований на забезпечення комерціалізації інтелектуального продукту консультантів, його визнання ринком консалтингових послуг. Змістом 
сервісного вектора є клієнтоорієнтованість консалтингового бізнесу, його спрямованість на найякісніше задоволення потреб споживачів консалтингових послуг.

По-друге, послуги бізнес-консалтингу належать до послуг «В2В»: послуги бізнесу для бізнесу (Business-to-Business). 3 одного боку, бізнес-консалтинг - це інтелектуальний бізнес професійних консультантів та їх підприємницьких організацій, 3 іншого боку, споживачами послуг бізнес-консалтингу (клієнтами) є суб'єкти підприємницької діяльності у різних галузях та сферах національної економіки. Головними аспектами змісту послуг бізнес-консалтингу $є$ такі:

- продуктовий - послуга бізнес-консалтингу - це інтелектуальний продукт професійних консультантів, змісту якого притаманні рівні: 1) сутнісний - спеціальні знання та інформація, необхідні для розв'язання проблем клієнта; 2) результативний потенційна (очікувана) та реальна вигода клієнта від використання консалтингових ресурсів у власному бізнесі. Їх взаємозв'язок та взаємозалежність виявляються у тому, що, з одного боку, вигода, очікувана клієнтом, безпосередньо пов'язана 3 одержанням консультаційної допомоги, з іншого боку - метою звернення клієнта до консультантів $є$ досягнення певного результату (отримання реальної вигоди) у бізнесі;

- ринковий. Ринок консалтингових послуг є складовою ринку послуг, ринкової інфраструктури та інфраструктури інноваційної діяльності, сегментом ринків ділових послуг, інтелектуальних ресурсів, інтелектуальної власності, інноваційних та освітніх послуг. Відповідно до об'єктного критерію сегментами ринку послуг бізнесконсалтингу є ринки різних видів консалтингової діяльності, а також ринки оперативного та стратегічно- інноваційного бізнес-консалтингу. Ринок послуг бізнес-консалтингу є: 1) ринком замовлень, що пов'язано 3 розривом у часі між замовленням та наданням консалтингових послуг: на ринку консультант пропонує клієнту свою здатність розв'язати його проблему, а клієнт формує платоспроможний попит на послугу, яка ще не існує та буде надаватися після укладення контракту 3 консультантом; 2) ринком клієнта, оскільки визначальна роль на ринку бізнес-консалтингу належить попиту на професійне консалтингове обслуговування;

- сервісний - надання послуг бізнес-консалтингу здійснюється як процес консалтингового обслуговування їх споживачів, яке може бути повним, що включає продукування, обмін та впровадження консалтингових продуктів, та частковим, завданням якого може бути 
продукування консалтингового продукту - продукуюче консалтингове обслуговування / впровадження певних знань, новацій, методів та заходів у господарську практику - впроваджувальне консалтингове обслуговування. Розуміння клієнта як центра уваги суб'єктів бізнесконсалтингу, діяльність яких спрямовується на визначення та найякісніше задоволення його потреб, є умовою досягнення цілей консалтингового бізнесу;

-процесний: професійні дії консультантів, спрямовані на забезпечення суб'єктів господарювання знаннями та інформацією, необхідними для розв'язання проблем бізнесу.

По-третє, бізнес-консалтинг $є$ суспільним каналом передавання та поширення у процесі надання консалтингових послуг спеціальних знань та інформації з різних галузей знань, з метою їх впровадження у господарську практику

Головним завданням консалтингового обслуговування бізнесу $є$ забезпечення ефективності та конкурентоспроможності суб'єктів підприємництва шляхом впровадження досягнень науки та практики, професійних знань та інформації у господарську діяльність.

Система функцій бізнес-консалтингу включає:

-власні функції 3 забезпечення суб'єктів підприємництва спеціальними знаннями та інформацією, необхідними для їх ефективного функціонування: 1) накопичувальна функція - діяльність професіональних консультантів та їх організацій 3 одержання, збереження та нагромадження головного ресурсу бізнес-консалтингу спеціальних знань та інформації; 2) ретрансляційна функція як передавання суб'єктами консалтингової діяльності економічним агентам необхідних професійних знань та інформації, головним каналом одержання яких є ринок консалтингових послуг; трансакційна функція (інфраструктурного забезпечення бізнесу) - діяльність професіональних консультантів, спрямована на забезпечення ефективних ринкових угод та економію трансакційних витрат суб' єктів господарювання;

-вмінені (поставлені) функції як напрями реалізації призначення бізнес-консалтингу, зумовлені його роллю як постачальника бізнесу консалтингових ресурсів, чинника його ефективності та конкурентоспроможності: 1) раціоналізуюча функція професіональне сприяння раціоналізації бізнес-процесів, оптимізації комбінації та використання ресурсів, підвищенню ефективності шляхом забезпечення бізнесу спеціальними знаннями та інформацією; 2) інноваційна функція як сприяння впровадженню нових знань та досвіду в господарську практику. Інноваційна діяльність суб'єктів 
бізнес-консалтингу за її спрямованістю є: а) внутрішньою - розробка, впровадження, використання інноваційних консалтингових послуг, новацій у технологіях та методах консультування тощо; б) зовнішньою - професійне сприяння інноваційній діяльності економічних агентів шляхом передавання їм новітніх знань та інформації. Внутрішня та зовнішня складові інноваційної діяльності суб'єктів бізнесконсалтингу є взаємозалежними та взаємопов'язаними, визначають їх інноваційність - здатність до інновацій, та інновативність як певний рівень сприйняття інновацій консультантами та консалтинговими фірмами. Внутрішня інноваційна діяльність у сучасний період набуває значення головного чинника ефективності та конкурентоспроможності суб'єктів бізнес-консалтингу; 3) регулююча функція, спрямована на оптимізацію економічної поведінки суб' єктів господарювання шляхом надання професійної допомоги у розв'язанні проблем бізнесу.

Власні та вмінені функції бізнес-консалтингу тісно взаємопов'язані, їх комплексна реалізація у процесі консалтингового обслуговування суб'єктів господарювання сприяє досягненню якісно нового рівня їх ефективності, конкурентоспроможності та інновативності, інтелектуалізації підприємницької діяльності, підвищенню інноваційної активності бізнесу.

Бізнес-консалтингу притаманні:

- інформаційний ефект, оскільки інформаційне забезпечення бізнесу $є$ невід'ємним елементом реалізації власних та вмінених функцій бізнес-консалтингу;

- навчальний ефект як результат навчальної діяльності професіональних консультантів, спрямована на сприяння засвоєнню підприємцями та менеджерами бізнес-організацій нових знань, досвіду та інформації, що передаються у процесі надання консалтингових послуг;

- соціально-економічні ефекти, серед яких: забезпечення зайнятості, підвищення освітнього, ділового та інноваційного рівнів підприємців шляхом передавання та впровадження у господарську практику знань 3 новітніх підходів, заходів, методів, досвіду ведіння бізнесу, розвиток підприємницької культури та підвищення соціальної відповідальності бізнесу, сприяння ефективній інтеграції національного бізнесу у систему міжнародних економічних відносин, його адаптації до міжнародних правил та стандартів підприємницької діяльності. Суб'єкти бізнес-консалтингу здійснюють: а) соціальні програми, спрямовані на розвиток персоналу, що охоплюють навчання та підвищення кваліфікації працівників, фінансування соціальних заходів; забезпечення консультантів соціальним пакетом; запобігання 
конфліктам - це внутрішні соціальні ефекти бізнес-консалтингу; б) його зовнішніми соціальними ефектами втілюються у результатах впливу консалтингової діяльності на соціальний розвиток країни та регіонів через благодійність, участь у соціальних заходах тощо.

Таким чином, бізнес-консалтинг як професійне консалтингове обслуговування суб'єктів господарювання є структурним елементом сервісної економіки, розкриття змісту, функцій та напрямів розвитку якого є важливим напрямом наукових досліджень з економічної теорії послуг, економіки та організації сервісної діяльності, чинників інтелектуалізації бізнесу, діяльності сервісного підприємства, національного та світового ринку послуг.

Мудла Д.В., аспірант,

Київський національний торговельно - економічний університет

\section{ТЕОРЕТИЧНІ АСПЕКТИ МЕРЕЖЕВОЇ ЕКОНОМІКИ}

Розвиток інформаційних технологій сприяє формуванню нових структурних відносин, що формують мережеву економіку. Стратегічним та пріоритетним завданням для національної економіки $\epsilon$ перехід на інноваційний шлях розвитку, що підвищить конкурентоспроможність України на світовому ринку. Сучасна форма інтеграції бізнесу в мережевій економіці відповідає інноваційній стадії економічного розвитку.

Теоретичні аспекти мережевої економіки досліджено в роботах вітчизняних науковців: Бусарєва Т.Г, Губені Ю.Е, Кіт Л.3, Кравчук О.I, Нечипурук Л.В, Пушак Я.Я, Топішко Н.М та інші.

Мережева економіка $є$ основою інформаційного суспільства. Впровадження електронних технологій створює нові можливості для учасників ринку і значно підвищує конкурентоспроможність.

Кравчук O.I визначає мережеву економіку як особливу форму економічної діяльності, що базується на горизонтальних зв'язках, глобальному електронному середовищі, 3 переважанням у якості найважливіших елементів продуктивних сил знань, інформації та відносин, що забезпечують миттєву реакцію на попит і пропозицію; природа мережевої економіки заснована на різноманітних тісних зв'язках між суб'єктами відносин і являє собою нову форму 
управління, яка відрізняється від ринкової та децентралізованої форми управління економічною діяльністю [1].

Діяльність, заснована на використанні інформаційних i телекомунікаційних технологій, забезпечує взаємодію суб'єктів господарювання за допомогою комп'ютерних технологій, формує нові моделі розвитку бізнесу. Традиційні бізнес-процеси в мережевій економіці набувають нових форм.

На думку Губені Ю.Е дефініція «мережева економіка» виникла в результаті розвитку інформаційних технологій та використання нових організаційних моделей управління господарськими процесами, при цьому форма і зміст мережевої економіки не залежить від типу та моделі економічної системи, в якій вона функціонує [2].

Мережева економіка доповнює та трансформує ринкові форми господарювання новими властивостями.

Кіт Л.3 стверджує, що мережева економіка - це одна з мережевих форм організаційно-економічної діяльності в рамках моделі ринкової економіки з високим рівнем інформатизації, заснованої в активному використанні господарюючими суб'єктами, інформаційнокомунікаційними технологіями та глобальною електронною мережею Інтернет в процесах громадського відтворення [3].

В інформаційному суспільстві суттєво зростають масштаби електронної торгівлі 3 прискореною динамікою між попитом i пропозицією. Змінюється модель взаємодії бізнесу зі споживачем.

Нечипурук Л.В зауважує, що мережева економіка грунтується на виробництві та розподілі мережевих благ, корисність яких виявляється виключно через мережеві зв'язки, властивостями яких $\epsilon$ : комплементарність, стандартність; мережеві зовнішні ефекти; ефекти пастки, економія на масштабі виробництва [4].

Мережеві форми організації економіки застосовуються у всіх сферах народного господарства можуть здійснюватися в реальному та віртуальному середовищі.

Топішко Н.М стверджує, що використання інформаційних технологій формує економіку мережевої структури, при цьому інформація перетворюється на ресурс, а інформаційна мережа стає антиподом ринку; за надшвидкісного режими функціонування ринковий механізм уже не може виконувати роль економічного регулятора, хоча й використовується його функціональні форми та атрибутика, однак ця мережа $\epsilon$ економічними відносинами іншого суспільного порядку [5]. 
Можливість глобальних комунікацій між людьми, висока швидкість та гнучкість подій, створюють нові інструменти для реорганізації формальних ринкових структур.

Бусарєва Т.Г акцентує увагу, що в мережевій економіці розміщення виробничих сил набуває соціально-економічного характеру; домінування мережевої економіки дає більше можливостей для самореалізації людей, при цьому конкуренція стає жорсткішою і необхідно докладати додаткових зусиль для освоєння нових принципів, при цьому з'являється новий чинник соціальноекономічної нерівності - хто має кращий доступ до мережі i адаптований до ії особливостей, матимуть переваги над іншими [6].

Пушак Я.Я виділяє ключові механізми мережевої економіки в умовах формування глобального інформаційного простору, що допомагають оптимізувати ефективність роботи компаній: хмарні технології, консолідація бек-офісу, цифрове співробітництво, посилений взаємозв'язок, електронна комерція, автоматизація ланцюгів постачання, аналіз великих даних (Big Data) [7].

Мережева економіка знаходиться на етапі формування, а іiі динамічний розвиток потребує подальшого наукового дослідження. Сучасні тенденції розвитку економіки формуються на основі глобалізації та інтеграції світових процесів, характеризуються зміною моделей та методів ведення бізнесу, посиленням та зростанням конкуренції, стрімким розвитком інформаційних та комп'ютерних технологій.

В мережевій економіці формуються процеси які складно регулювати та контролювати: миттєве формування спекулятивних угод, асиметричність ринку, слабкий захист електронної інформації ітд, все це негативно впливає на соціально-економічний розвиток. Мережева економіка являє собою іншу форму економічних відносин, поява яких зумовлена швидким розвитком та розповсюдженням інтернет технологій, що ускладнює державне регулювання та контроль. Важливе значення має державна підтримка, успішна реалізація якої можлива при формуванні та вдосконалені нормативно-правової бази.

Концепція мережевої економіки ще проходить стадії формування, тому однозначно складно визначити іiі теоретикометодологічний зміст та подальший розвиток. 


\section{Список використаних джерел}

1. Кравчук O. I. Мережева економіка - Домінанта розвитку економічних і соціально-трудових відносин // Соціально-трудові відносини: теорія та практика. - 2016. - № 2. - С. 108-114.

2. Губені Ю. Мережева економіка: теоретичні аспекти / Ю. Губені, О. Корчинський, П. Оліщук // Вісник Львівського національного аграрного університету. Серія: Економіка АПК. - 2017. - № 24 (1). - C. 9-12.

3. Кіт Л. 3. Еволюція мережевої економіки / Л. 3. Кіт // Вісник Хмельницького національного університету. Економічні науки. 2014. - № 3(2). - С. 187-194.

4. Нечипорук Л. В. Теоретичні аспекти формування мережевої економіки / Л. В. Нечипорук // Економічна теорія та право. - 2015. - № 1. - С. 76-84

5. Топішко Н. П. Мережева економіка як форма соціальноекономічної організації в глобальних координатах / Н. П. Топішко, I. I. Топішко, T. I. Галецька // Наукові записки національного університету "Острозька академія". Серія: Економіка. - 2018. - № 8. - С. 33-38.

6. Бусарєва Т. Г. Мережева економіка як нова форма розвитку економіки / Т. Г. Бусарєва // Бізнес-навігатор. - 2018. - Вип. 4. - С. 9

7. Пушак Я. Я. Сучасні тенденції розвитку мережевої економіки на підприємствах в умовах глобальних викликів / Глобальні та національні проблеми економіки. - 2017. - №18. - С.608-612. 
Носова О.В., д.е.н., професор Університет Банківської Справи, ДВНЗ, ХННІ Носова Т.Ю., к.е.н., доцент Харківський Національний Університет Внутрішніх Справ

\section{ІЕРАРХІЧНІ І МЕРЕЖЕВІ СТРУКТУРИ В ІНСТИТУЦІЙНІЙ ЕКОНОМІЦ}

Проблема забезпечення функціонування економічних інститутів і виявлення напрямків скорочення трансакційних витрат, пов'язаних $з$ їх роботою, відноситься до числа актуальних питань інституційної економіки. Ієрархія економічних інститутів передбачає поділ і узгодження функцій, які виконуються різними рівнями ієрархічної системи організації, що визначає збалансованість їх дій.

Метою даної статті є розкриття порівняльних характеристик, механізмів забезпечення ефективної взаємодії ієрархії економічних інститутів i мережевих форм організації. В економічній науці дослідження проблеми ієрархії інститутів знайшло відображення в роботах вчених в різних галузях знань: О. Аузана, О. Боголюбова, В. Горелик, А.А. Гриценка, С. Гурмана, Д. Норта, М. Кастельса, Ф. Кононенка, К. Левіна, Я. Морена, Л. М'ясникова, О. Оляскіна, Д. Петерсона, О. Вільямсона, Ф. Хараре, С. Хідетніемі, В. Шемятєнкова та інших.

Управління суспільством, організмом, пізнавальними процесами і поведінкою людини будується і здійснюється відповідно до ієрархічних принципів. В економічній літературі ієрархія розглядається як спосіб побудови, організації складних систем, в першу чергу систем управління економічними об'єктами, причому частини (елементи) системи розподілені за рівнями, і вся система стає багаторівневою, багатоступінчастою, такою, що володіє властивостями цілісності [1, с. 440]. Ієрархії представляють складне соціальне явище. Соціальна ієрархія - це ієрархічна структура, що характеризується нерівністю статусів, владних відносин, неоднаковим доступом до отримання та розподіла прибутку [2, с.118]. Соціальна ієрархія виявляється в централізації управління, а також в його бюрократизації. Більшість авторів зазначає одночасне поєднання 
елементів ієрархії і мережі протягом історичного розвитку сучасної цивілізації. «Первісне суспільство, - вказує А.А. Гриценко, - засноване на взаємозв'язку рівних членів - по суті мережеве, а ієрархія розчинена в середині нього i поступово разом 3 накопиченням досвіду викристалізується 3 функціональною відмінністю в закріпленому статусі окремих індивідів, вождів та інших. Але основа ії залишається мережевою. Це приклад синкретичної єдності» [3, с. 84]. Ієрархія передбачає залежність між суб'єктами. Виникнення залежності одного суб'єкта від іншого супроводжується виникненням нової ієрархії. Ієрархія $є$ багаторівневою структурою, яка характеризується стосунками підпорядкування та координації іiі елементів. Мережа розглядається в якості структури, в якій елементи знаходяться в рівних горизонтальних відносинах взаємодії і координації.

Інституційний підхід досліджує вплив діючих інститутів на організацію роботи економічних суб'єктів. Ринкові агенти використовують різні форми поведінки щодо прийняття рішень. Формальні і неформальні правила можуть змінюватися за видами. Ефективність трансакцій підвищується в результаті координації індивідуальних правил. Права власності, вільне укладання контрактів і обов'язкове їх виконання утворює систему конкуруючих інститутів. Ієрархія загальних і специфічних правил включає Конституцію, закони і підзаконні акти та інструкції. Іерархія зовнішніх інститутів створює основу для стабільності і забезпечує сталість дотримання правил до нижчого рівня. Контрактна система відносин між роботодавцем і найманим робітником створює впевненість при укладенні безстрокових контрактів. Система правил припускає облік i можливість включення непередбачених обставини при складанні контрактів. Правила вищого порядку створюють каркас передбачуваності, і обов'язковості дотримання правил нижчого рівня $[4$, c. 83$]$.

Особливості дослідження ієрархічних форм в інституційній економіці включають такі характерні риси. По-перше, в процесі проведення ринкових реформ традиційні ієрархічні структури були замінені на більш гнучкі і рухливі мережеві форми організації в різних сферах діяльності. По-друге, механічне копіювання та перенесення інституційних форм без урахування особливостей функціонування транзитивної економіки стало причиною відсутності узгодженості в роботі інститутів. У ринковій економіці панують принципи індивідуалізму, методологічного індивідуалізму, альтруїстичного індивідуалізму (індивідуального милосердя, космополітизму). Інституційна ієрархія представляє багаторівневу, багатоступеневу 
систему взаємовідносин між суб'єктами через існуючу мережу інститутів і виявляється в адміністративно-правових нормах, актах, що визначають поведінку ієрархічної організації, закріплених в суспільстві. При переході від одного типу економічної системи до іншої відбувається зміна інституційної ієрархії, що супроводжується зняттям відносин підпорядкування та координації в рамках існуючої ієрархії і призводить до виникнення нових суб'єктних відносин. Панування ієрархічної структури допускає підпорядкування елементів системи «правилам» за допомогою застосування системи примушення. Керованість ієрархічних структур може збільшуватися за рахунок вдосконалення методів і засобів управління, підвищенням рівня професійної підготовки та якісного виконання своїх обов'язків працівниками. Розширення горизонтальних зв'язків поряд iз зростанням вертикальної ієрархії призводить до скорочення інформаційних витрат, сприяє підвищенню стандартів трудової етики. Перехід до ринкової системи супроводжується появою гнучких структур у формі фінансово-промислових груп, холдингів, що функціонують на великій території і які об'єднують значну кількість учасників.

Ієрархії існують в різних формах. Сучасна корпорація виступає однією з форм іiї прояву. В економічній літературі набула поширення точка зору, яка розглядає ієрархію і мережу як тотожні поняття [5, с. 22]. На - нашу думку, ієрархія - це мережа правил при укладанні угод, яка грунтується на вертикальних зв'язках рішень, що приймаються владою. Діюча система інститутів гарантує дотримання внутрішніх правил в суспільстві. Виконання зобов'язань і дотримання контрактів досягається шляхом реалізації функції нагляду.

Мережі відображають виникнення нових організаційних структур, які представляють об'єднання безлічі вузлів, які не мають ні верху, ні низу, ні центру, ні периферії. Мережеві структури розглядаються в якості нової організаційної форми сучасного суспільства. Мережі визначаються як організаційні структури, що спонтанно виникають і зникають, які характеризуються елементами непередбачуваності, спонтанності і хаотичності [6, с. 386]. Розвиток мережевих структур вказує на їх високі адаптаційні можливості, на міцність зв'язків між учасниками мережі та гнучкість, що виражається в швидкій реакції на технологічні зміни.

Поява мережевої людини пов'язана з включенністю людини в декілька мереж, що пояснює непослідовність і нелогічність поведінки людей, призводить до зростання хаотичності зв'язків і наростання конфліктів в суспільстві. До негативних наслідків функціонування 
мережевої економіки відносяться ризики фрагментації в різних сферах і сегментах соціально-економічної системи, що призводять до розпаду особистості і деградації соціальних відносин. Функціонування ділових мереж стимулює розвиток співпраці і неформальної взаємодії, скорочує час на використання нових ідей і їх виведення на ринок, збільшує доступ членів мережі до нової інформації. Велике значення приділяється довірі і репутації в процесі розвитку взаємин між фірмами. Включення в мережі потенційних клієнтів, встановлення контактів 3 членами мережі скорочують трансакційні витрати i спрямовано на розширення ділових відносин, підвищує ступінь довіри між учасниками мережі та їх співпрацю. До недоліків функціонування мереж відносяться додаткові витрати при їх утворенні, закритість, відсутність припливу інформації та нових ресурсів в замкнутих мережах, невикористання економії від масштабу виробництва. Організація мережевих структур не вимагає управління ними з центру, тому що для створення продукту використовуються колективні активи кількох фірм, пов'язаних вартісним ланцюжком, причому в ролі фірм можуть виступати і регіони. Таким чином, в основі роботи мережевих організацій можуть лежати найрізноманітніші моделі, і визначальний вплив на цей процес надає глобалізація. Визначення порівняльних переваг ієрархії і мережі і виявлення можливих ефектів в процесі їх спільного функціонування відноситься до важливої проблеми використання в творчих цілях при мінімізації негативних ефектів.

В умовах переходу до постіндустріального суспільства відбулася заміна традиційних форм ієрархічних структур на нові, змішані моделі господарської організації. Розвиток сучасних транснаціональних компаній, транснаціональних банків, різних асоціацій, міжурядових установ свідчить про використання в них елементів, як традиційної ієрархії, так і мережі, що відповідає на виклики глобальної економіки. Поєднання вертикально організованих зв'язків, що мають чітку вертикальну супідрядність 3 більш розгалуженими горизонтальними взаємозв'язками, що швидко реагують на зміни, дозволяє використовувати переваги обох структур. Перевагами змішаних структур є мінімізація кількості управлінських рівнів, гнучкість мережевих взаємодій, ефективність зворотних зв'язків. Переваження, будь - якого виду взаємозв'язків на шкоду іншому виду викликає порушення стійкості системи і призводить до іiі розбалансування [7, с. 107].

Розвиток ринкових інститутів супроводжується зменшенням трансакційних витрат, що підвищує ступінь конкурентності ринкових структур. Внаслідок роботи неефективних інститутів, існування 
адміністративних бар'єрів господарської діяльності в перехідній економіці трансакційні витрати залишаються дуже високими. Проведення лібералізації економічних відносин шляхом передачі повноважень низовим рівням ієрархії інститутів дозволить підвищити їх економічну самостійність і усунути протиріччя, що породжуються надмірно жорсткими вертикальними зв'язками.

\section{Список використаної літератури}

1. Борисов А.Б. Большой экономический словарь / Борисов А.Б М.: Книжный мир, 2003. - 895 с.

2. Соціологія: словник термінів і понять; за. ред. Є.А Біленькою. і М.А. Козловця. - Київ, Кондор, 2006. - 370 с.

3. Іерархія і мережеві структури: історія і сучасність (Матеріали семінару. Частина 1 // Економічна теорія. 2007. № 4. С. 83-105.

4. Носова Т.Ю., Ушакова Н.Г. Институциональная конкурентоспособность иерархических и сетевых структур в экономике [[Текст]: монография/ Т.Ю. Носова, Н.Г. Ушакова. - Х.: ХГУПТ, 2011. - 175 с.

5. Тарасевич В.Н. Что такое институт? (Опыт институциональной теории)// Журнал институциональных исследований.-2010.-Том 2.- № 3. C. $5-23$.

6. Носова О.В. Иерархия и сети в институциональной архитектонике экономических систем. Колл. моногр. Под ред. А.А. Гриценко, НАН Украины, Институт экономики и прогнозирования. Киев, 2013. - С. $384-403$.

7. Nosova O.V. The impact of globalization on financial institutions' development// Europa regionum. -Tom XXX. -Household Finance. Uniwersytet Szczecinski. -2017. -№ 1.- P. 99 -119. 
Підвисоцький Я. В. к.е.н., асистент

Київський національний університет імені Тараса Шевченка, Інститут міжнародних відносин

\section{МЕТОДИКА КОНСТРУЮВАННЯ ФІНАНСОВИХ ІННОВАЦІЙ З МЕТОЮ УПРАВЛІННЯ ІНВЕСТИЦІЙНИМИ РИЗИКАМИ}

В процесі управління ризиками інвестиційного характеру фінансовому інженеру необхідно займатися не лише пошуком нових ідей, а й конструюванням елементів прав та зобов'язань за фінансовими контрактами.

Методика конструювання залежить від таких чинників:

- типології ризику або групи ризиків, якими потрібно управляти в процесі інвестування;

- характеру прав та зобов'язань за контрактом чи контрактами, які становлять загрозу втрати частини прибутку;

- наявності типових елементарних чи похідних інструментів, які вже увійшли у практику фінансової інженерії;

- генерації нових форм договірних конструкцій, пов'язаних факторами часу, події чи поведінки економічних суб'єктів тощо.

Інвестиційні ризики мають широкий спектр загроз, що виникають внаслідок недостатності чи відсутності певних видів прав за контрактами; обтяжливості та недосконалості пунктів зобов'язань; неможливості управління ризиками форс-мажору.

Обираючи інструмент чи комплекс інструментів для управління такими ризиками необхідно звертати увагу на те, що може скластися ситуація, коли жоден інструмент не зможе суттєво вплинути на результат. У такому разі необхідно знати певні методичні рекомендації, щоби сконструювати потрібний інструмент, який у майбутньому може стати інноваційним продуктом.

Процес конструювання доволі складний, однак для кращого сприйняття його можна представити за допомогою методу аналогій, порівнявши із процесом приготування певної страви.

У фінансовій інженерії виділяють наступні технології конструювання фінансових інновацій:

- комбінування; 
- структурування;

- заміщення.

Кожна технологія передбачає особливий порядок модифікації базисних (базових) активів на основі таких факторів, як:

- час (графік виконання зобов'язань та використання прав, прописаних у контрактах);

- подія (дія, випадкова чи закономірна, викликана обставинами внутрішнього чи зовнішнього середовища);

- поведінка (свідома чи несвідома дія суб'єкта договірних відносин, спричинена його особистим вибором у прийнятті управлінського рішення). [1, с. 32-33]

Суть методики комбінування полягає у конструюванні нового фінансового інструменту 3 ряду відомих (елементарних та/чи похідних) шляхом поєднання необхідних і відкидання зайвих прав та зобов'язань за контрактами. Подібно до приготування салату, необхідно відібрати інгредієнти, кожен 3 яких має певні смакові властивості. Поєднуючи корисні властивості та смаки для організму різних елементів і відкидаючи непотрібні (наприклад, лушпиння), кухар створює кулінарний продукт, готовий для споживання. Так само й фінансовий інженер, виконуючи процедуру селекції пунктів контрактів, утворює інноваційний продукт для споживання ризикменеджерами на фінансових ринках.

В результаті використання технології комбінування з'явились такі інструменти, як конвертована облігація, мезонінне фінансування, катастрофічна облігація, свопціон тощо. Ці інструменти зменшують широкий спектр загроз, пов'язаних 3 інвестуванням: виробничі, фінансові, комерційні ризики, а також ризики форс-мажорних обставин природного характеру (стихійні лиха).

Технологія структурування полягає у відборі властивостей базисного інструменту чи групи інструментів за певним параметром чи параметрами, упорядкуванні та виокремленні серед інших інструментів зі схожими властивостями. Опісля новоутворені базисні інструменти шляхом дезагрегації ризиків і передачі їх в управління третім сторонам стають основою для інноваційного структурованого інструменту [2, с. 16-17]. Якщо вдатися до порівняння із кулінарією, то процес створення структурованого продукту можна порівняти 3 випіканням багатошарового торту, де у якості коржів виступають однорідно структуровані інгредієнти.

Структуровані фінансові продукти сприяють розв'язанню задач iз управління ризиками переважно кредитного характеру. До них належать інструменти сек'юритизації (ABS, MBS, CMO), кредитні 
деривативи (CDS, CSS, TRS) та гібридні структуровані продукти (CLN, CDO та ін.). Ступінь ризикованості інвестування у такі інструменти безпосередньо пов'язана з рівнем надійності позичальників фінансової установи. Тому процес структурування має відбуватися з урахуванням жорсткої селективної політики та постійного моніторингу.

Інструменти заміщення являють собою новітні результати конструювання не лише фінансових, а й реальних активів. Часто останні заміщують елементарні чи похідні базові активи. До реальних активів належать об'єкти інфраструктури, будівництва, транспорту, зв'язку, а також права на об'єкти реальної економіки. Економічний смисл полягає у тому, що при збереженні фінансових механізмів використання основних фондів в управління інвестиційними ризиками сприяє більш ефективному перерозподілу капіталу не лише на макрорівні, а й на макрорівні.

До інструментів заміщення належать реальні опціони та гібриди реальних опціонів з іншими базисними активами (складені реальні опціони).

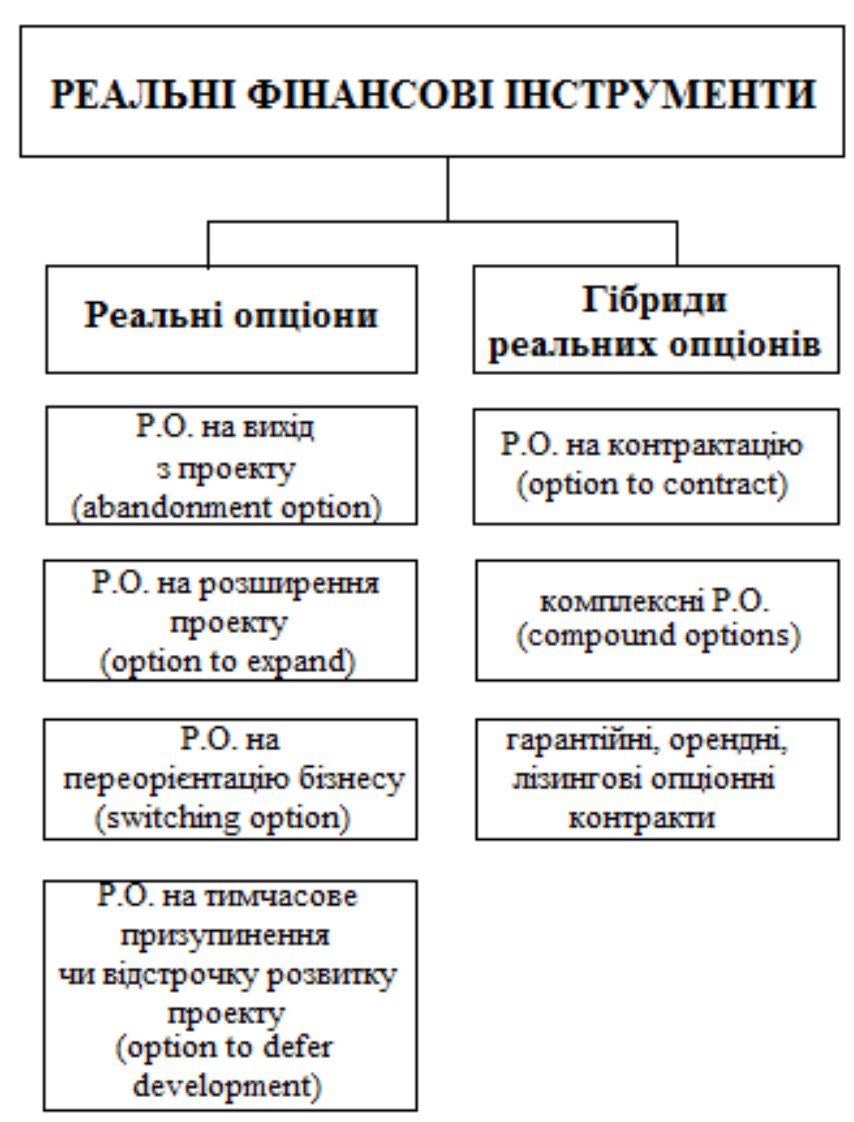

Рис.1. Класифікація інструментів технології заміщення [3, с. 176] 
Технологія заміщення важлива 3 точки зору вирівнювання дисбалансів у світовій економіці, особливо після фінансових потрясінь. Остання економічна криза довела, що порушення розподілу капітальних активів у світі може призводити до зниження рівня економічного розвитку як бідних, так і багатих країн. I якщо багаті країни є більш стійкими до потрясінь на грошово-кредитних ринках, то бідні країни перебувають у постійній залежності від інвестиційних надходжень. Реальні фінансові інструменти сприяють активізації реального сектору економік, притоку іноземних інвестицій; підштовхують до розвитку промисловість, сільське господарство, сферу послуг; створюють соціальний ефект для суспільства.

Отже, грамотно сконструйовані фінансові інструменти 3 метою управління інвестиційними ризиками вирішують комплекс завдань, пов'язаних із ефективним перерозподілом капіталу, знижують рівень загроз втрати прибутку, сприяють відновленню балансу фінансового та реального сектора економік країн світу.

\section{Список використаних джерел}

1. Підвисоцький Я.В. Інноваційна складова сучасних міжнародних фінансових інструментів / Я.В. Підвисоцький // Актуальні проблеми економіки: Науковий економічний журнал. - №4 (118). - Київ. - 2011. - С. 32-38.

2. Дэвидсон Э., Секьюритизация ипотеки: мировой опыт, структурирование и анализ. / Э. Дэвидсон, Э. Сандерс, Л.-Л. Вольф, Ф. Чинг - М.: «Вершина», 2007. - 592 с.

3. Новітні форми міжнародного бізнесу в умовах глобальних інституційних та технологічних змін: монографія/ Д.П.Расшивалов, В.А.Вергун, В.П.Мазуренко та ін.; за ред. Д.П.Расшивалова. - К.: ВАДЕКС, 2019. - 540 с. 
Прутська О.О., д.е.н., професор

Вінницький національний аграрний університет

\section{СОЦІАЛЬНІ ІНВЕСТИЦІЇ В ПАРАДИГМІ РОЗВИТКУ ЕКОНОМІКИ ХХІ СТ.}

В усьому світі відбувається пошук можливих механізмів залучення приватних інвестицій для розв'язання соціально-економічних проблем, що знаходить свій вираз у розвитку новітніх форм інвестування і фінансових стратегій, які увійшли до наукового вжитку як категорії «соціального інвестування», «соціально-відповідального інвестування», «імпакт-інвестування», «соціального підприємництва». Найменш дослідженою в силу своєї новизни $є$ категорія «імпактінвестування».

В Україні науковому осмисленню імпакт-інвестування поки що не приділено належної уваги. Певний внесок в дослідження імпактінвестування як новітньої фінансової стратегії зробив Є.Попов[4]. Водночас в наукових дослідженнях достатньо поширеними i описаними $\epsilon$ терміни «соціальне інвестування» (англ. social investment), «соціально відповідальне інвестування» (англ. (socially) responsible investing; SRI), «соціальне підприємництво», які $\epsilon$ спорідненими, але не тотожними.

Термін імпакт-інвестування вперше було використано фондом The Rockefeller Foundation в 2007 році. Імпакт-інвестуванням називають інвестування впливу (impact investing), або інвестиції, які сприяють соціальним змінам і справляють позитивний вплив на соціально-економічну сферу i/aбо природне середовище.

На думку Є.Попова, імпакт-інвестори концентрують увагу на фінансових показниках та позитивних перетвореннях для майбутнього розвитку спільнот, середовищ, країн та планети. Причому, ці зміни мають бути досяжними та вимірюваними [4].

Імпакт-інвестиції розглядаються як вкладення в компанії, організації, фонди, які мають на меті поряд з отриманням доходу, вплив на соціальні фактори або навколишнє середовище. Інвестор зберігає за собою власність на активи й розраховує на отримання фінансового доходу. Важливо те, що інвестор, вкладаючись в проект, $\epsilon$ зацікавленим насамперед в соціальному впливові, а не в отриманні прибутку. Однак, такий вид вкладень не є благодійністю, проект 
повинен окупитися, а управління ним грунтується на принципах класичного інвестування.

Таким чином, імпакт-інвестування $\epsilon$ окремим випадком соціального інвестування з більш чітко визначеними межами. В чому ж відмінність імпакт-інвестування від інших видів соціального інвестування?

На думку А.В. Бондаренко, Л.О. Омелянович, «соціальне інвестування - це спосіб реалізації корпоративної соціальної відповідальності за допомогою цільових програм, які відповідають потребам основних груп зацікавлених осіб - споживачів, персоналу, місцевих громад» [3, с.201].

Бержанір А.Л. вважає, що «соціальне інвестування - спосіб реалізації корпоративної соціальної відповідальності за допомогою цільових програм, які відповідають потребам групам зацікавлених осіб-споживачів, персоналу, місцевих спілок» [2].

«Соціальні інвестиції - це добровільний внесок бізнесу в розвиток суспільства. До соціальних інвестицій найбільш часто відносять: спонсорство й корпоративну благодійність, піклування, взаємодію 3 місцевим співтовариством, владними структурами, корпоративні партнерські програми», - пишуть Шаповал В.М., Шаповал I.A. [5].

Однак, імпакт-інвестування не ототожнюється 3 соціальним підприємництвом. Програма ООН з розвитку (UNDP) визначає три головні принципи імпакт-інвестування. По-перше, це прибутковість. По-друге, здійснення позитивного впливу на суспільство та довкілля. I, по-третє, відповідальне ставлення до оцінки результатів проекту інвестори повинні відслідковувати, чи досягає він поставлених соціальних чи екологічних цілей [1].

Глобальна мережа імпакт-інвесторів (Global Impact Investing Network, GIIN) визначила чотири критерії імпакт-інвестицій (табл.1.) Таблиия 1

Критерії імпакт-інвестицій*

\begin{tabular}{|l|l|l|l|}
\hline \multicolumn{4}{|c|}{ Критерії імпакт-інвестицій } \\
\hline $\begin{array}{l}\text { Чітко визначено } \\
\text { соціальна мета }\end{array}$ & \multicolumn{1}{|c|}{$\begin{array}{c}\text { Окупність } \\
\text { витрат }\end{array}$} & \multicolumn{1}{|c|}{ Прибутковість } & $\begin{array}{l}\text { Вимірювання й оцінка } \\
\text { соціального впливу } \\
\text { (імпакту) }\end{array}$ \\
\hline $\begin{array}{l}\text { В бізнес-плані } \\
\text { прописується } \\
\text { очікуваний } \\
\text { соціальний } \\
\text { результат }\end{array}$ & $\begin{array}{l}\text { Інвестиції } \\
\text { повинні } \\
\text { окупитися в } \\
\text { довгостроковом } \\
\text { у періоді }\end{array}$ & $\begin{array}{l}\text { Повинен існувати } \\
\text { взаємозв'язок між } \\
\text { соціальним } \\
\text { результатом і } \\
\text { економічною вигодою }\end{array}$ & $\begin{array}{l}\text { Необхідні для оцінки } \\
\text { ступеня досягнення } \\
\text { соціальних цілей }\end{array}$ \\
\hline
\end{tabular}


*Укладено автором на основі [5]

Імпакт-інвестиції допомагають виміряти зовнішні ефекти ведення бізнесу. Завдяки введенню критерію імпакту від інвестицій ми звертаємо увагу на те, яким саме є цей вплив бізнесу так як його виміряти, вивчити та зрозуміти.

Узагальнення існуючих наукових поглядів на сутність різних інвестицій соціального характеру дозволило виділити особливості кожного їх виду (табл.2)

Таблиия 2

Відмінності між різними видами інвестицій соціального характеру*

\begin{tabular}{|c|c|c|c|}
\hline Благодійність & $\begin{array}{c}\text { Соціальне } \\
\text { підприємництво }\end{array}$ & $\begin{array}{c}\text { Соціально- } \\
\text { відповідальне } \\
\text { інвестування }\end{array}$ & Імпакт-інвестиції \\
\hline $\begin{array}{c}\text { Витрати, } \\
\text { орієнтовані на } \\
\text { допомогу та } \\
\text { покращення } \\
\text { суспільства, } \\
\text { окремих його } \\
\text { верств чи осіб. } \\
\text { Джерело - доходи, } \\
\text { отримані від іншої } \\
\text { діяльності. } \\
\text { Не передбачає } \\
\text { окупності і } \\
\text { прибутковості }\end{array}$ & $\begin{array}{c}\text { Проекти, } \\
\text { розраховані на } \\
\text { здійснення } \\
\text { цілеспрямованої } \\
\text { довгострокової } \\
\text { політики компанії у } \\
\text { місцевих } \\
\text { співтовариствах, } \\
\text { спрямованої на } \\
\text { вирішення } \\
\text { суспільно важливих } \\
\text { завдань }\end{array}$ & $\begin{array}{c}\text { Інвестиції в } \\
\text { бізнес-проекти, } \\
\text { які не наносять } \\
\text { шкоди соціальній } \\
\text { спільноті та } \\
\text { природному } \\
\text { середовищу }\end{array}$ & $\begin{array}{c}\text { Інвестиції, які } \\
\text { сприяють соціальним } \\
\text { змінам і справляють } \\
\text { позитивний вплив на } \\
\text { соціально- } \\
\text { економічну сферу } \\
\text { i/або природне } \\
\text { середовище. } \\
\text { Характеризуються } \\
\text { окупністю, } \\
\text { прибутковістю, } \\
\text { виміром соціального } \\
\text { результату }\end{array}$ \\
\hline
\end{tabular}

Global Impact Investing Network оцінюе обсяги світових інвестицій в подібні проекти на рівні 228 млрд дол. США станом на 2017 р. В світовому масштабі це не так і багато, проте цей напрямок розвивається надзвичайно швидко. Ще 2014 р. сумарна оцінка проектів імпакт-інвестування ледве перевищувала 10 млрд дол. США, тобто протягом трьох років відбулося зростання в 22 рази [1].

В Україні імпакт-інвестування тільки починає розвиватись. За останні 4 роки приклади подібних інвестицій з'явились у Києві, Львові, Одесі, Івано-Франківську та інших містах. Більшість 3 них почали свою діяльність завдяки місцевому бізнесу, і за світовими мірками мають досить незначні початкові інвестиції [4].

\section{Список використаних джерел}

1. Баранова Н. Что такое импакт-инвестирование: разбираемся в терминологии URL: https:/te-st.ru/2017/09/12/impactinvestment-terms/ 
2. Бержанір А.Л. Соціальне інвестування як форма реалізації соціальної відповідальності бізнесу URL: http://www.confcontact.com/2017-ekonomika-i menedzhment/8 berzhanir.htm (дата звернення: 02.04.2019)

3. Бондаренко А.В., Омелянович Л.О. Соціальне інвестування як фактор забезпечення соціально-економічного розвитку держави. Вісник Донбаської національної академії будівництва і архітектури. 2009. - № 5(79). - С.201-203.

4. Попов С. Імпакт-інвестиції як нове покоління бізнесу: 5 сфер, де бізнес змінює українські міста URL: https://life.pravda.com.ua/columns/2019/01/11/235034/ (дата звернення: 02.04.2019)

5. Шаповал B.M., Шаповал I.А. Соціальні інвестиції як інструмент реалізації соціальних програм сучасних компаній URL: http://ir.nmu.org.ua/bitstream/handle/123456789/147366/7881.pdf?sequen ce=1\&isAllowed=y (дата звернення: 02.04.2019)

Романишин B.O., к.е.н., доцент ДВНЗ «Київський національний економічний університет імені Вадима Гетьмана» Гавриленко Ю.О., здобувач освітнього ступеня магістр ДВНЗ «Київський національний економічний університет імені Вадима Гетьмана»

\section{СТИМУЛЮВАННЯ ІННОВАЦІЙНОї ДІЯЛЬНОСТІ НАЦІОНАЛЬНИХ ПІДПРИЕМСТВ}

В сучасних умовах глобалізації та насиченості ринку різноманітними товарами й послугами основоположним чинником підвищення конкурентоспроможності підприємств $\epsilon$ їх здатність генерувати та впроваджувати інновації у свою діяльність.

Сприятливе геополітичне розташування, чималий інтелектуальний капітал та ментальність населення потенційно могли 
б стати каталізаторами розвитку інноваційної діяльності, та, як наслідок, економіки нашої держави. Але, наразі, Україна позиціонується як сировинний придаток на світовій арені (частка сировинної продукції в експорті становить близько 70\%).

Невтішними $є$ й дані стосовно інноваційної діяльності національних підприємств. Так, у 2017 році всього лиш 14,3\% суб'єктів господарювання впроваджували інновації, що на 2,9\% менше, ніж у 2015 році. Також, мізерною була частка реалізованої інноваційної продукції в обсязі промислової продукції- 0,7\% (вдвічі менше, ніж у 2015 році).

Виокремимо основні чинники, що спричиняють таку ситуацію та перешкоджають впровадженню інновацій на вітчизняних підприємствах (рис.1).

Чинники, що перешкоджають впровадженню інновацій на підприємстві

\begin{tabular}{|c|c|c|}
\hline Рівень підприємства & Рівень держави & Рівень суспільства \\
\hline - Нестача власних коштів, обмежене & - Декларативний .. характер & - Непл \\
\hline коло джерел фінансування & програм та стратегій активізації & можний попит \\
\hline $\begin{array}{l}\text { - Нестабільна економічна та } \\
\text { політична ситуація }\end{array}$ & $\begin{array}{l}\text { інноваційної діяльності (ІД) } \\
\text { - Невизначеність пріоритетів та }\end{array}$ & $\mid$\begin{tabular}{|l}
$\mid-$ Відсутність попиту \\
на
\end{tabular} \\
\hline - Велика вартість впровадження & несистематичний характер & |продукцію \\
\hline інновацій та високий ризик & заходів, що здійснюються & - В пріоры \\
\hline $\begin{array}{l}\text { - Недостатня } \\
\text { кваліфікованих кадрів }\end{array}$ & $\begin{array}{l}\text { - Недостатнє фінансування ІД } 3 \\
\text { Державного бюджету України }\end{array}$ & $\begin{array}{l}\text { ціновий аспект, а не } \\
\text { інноваційність }\end{array}$ \\
\hline $\begin{array}{l}\text { - Відсутність інформації про нові } \\
\text { технології, ринки збуту та ін. } \\
\text { - Відсутність стимулів }\end{array}$ & $\begin{array}{l}\text { - Відсутність дієвих механізмів } \\
\text { стимулювання впровадження } \\
\text { інновацій на підприємствах }\end{array}$ & $\mid \begin{array}{l}\text { продукції } \\
- \text { Низький рівень } \\
\text { інформування }\end{array}$ \\
\hline $\begin{array}{l}\text { - Орієнтація на короткострокову } \\
\text { перспективу та наявні ринки збуту }\end{array}$ & $\begin{array}{l}\text { - Недосконалість } \\
\text { законодавства у сфері ІД }\end{array}$ & $\begin{array}{l}\text { споживачів про } \\
\text { інноваційну }\end{array}$ \\
\hline
\end{tabular}

Рис. 1. Чинники, щзо перешкоджають впровадженню інновачій на підприємстві

Джерело: складено автором

На нашу думку, ключовими серед перелічених вище факторів наразі виступають саме фактори державного рівня. Адже, ключову роль у сприянні активізації інновацій на підприємствах відіграє саме державне регулювання. Розглянемо які ж форми стимулювання інноваційної діяльності підприємств використовують країни, що займають передові позиції у Global Innovation Index (табл. 1). Зокрема, Великобританія (4 місце), США (6 місце), Німеччина (8 місце), Японія (13 місце) та Франція (16 місце) [1]. 
Таблиия 1

Форми стимулювання інноваційної діяльності підприємств у найрозвиненіших краӥнах світу

\begin{tabular}{|c|c|c|c|c|}
\hline США & Японія & Великобританія & Франція & Німеччина \\
\hline $\begin{array}{c}\text { Пільгове } \\
\text { оподаткування, } \\
\text { інвестиційний } \\
\text { податковий кредит, } \\
\text { пільговий режим } \\
\text { амортизаційних } \\
\text { відрахувань, субсидії, } \\
\text { цільові асигнування з } \\
\text { бюджету, викреслення } \\
\text { витрат на НДдКР, } \\
\text { пов’язаних з основною } \\
\text { виробничою і торговою } \\
\text { діяльністю, із суми } \\
\text { оподаткованого доходу }\end{array}$ & $\begin{array}{c}\text { Пільгові } \\
\text { кредити, } \\
\text { пільгове } \\
\text { оподаткуванн } \\
\text { я, субсидії }\end{array}$ & $\begin{array}{c}\text { Пільгове } \\
\text { оподаткування, } \\
\text { субсидії, } \\
\text { списання витрат } \\
\text { на НДДКР на } \\
\text { собівартість } \\
\text { продукції (послуг, } \\
\text { кредитні гарантії) }\end{array}$ & $\begin{array}{c}\text { Дотації, } \\
\text { субсидії, } \\
\text { довгострокові } \\
\text { позики, } \\
\text { податкові } \\
\text { кредити, } \\
\text { кредитні } \\
\text { гарантії, } \\
\text { пільгове } \\
\text { оподаткування }\end{array}$ & $\begin{array}{c}\text { Цільові } \\
\text { безоплатні } \\
\text { субсидії, дотації, } \\
\text { оплата витрат на } \\
\text { технічну } \\
\text { експертизу, } \\
\text { пільгові кредити, } \\
\text { система } \\
\text { страхування } \\
\text { кредитів, } \\
\text { податкові знижки } \\
\text { і пільги, } \\
\text { прискорена } \\
\text { амортизація, } \\
\text { цільові банківські } \\
\text { кредити }\end{array}$ \\
\hline
\end{tabular}

Джерело: складено автором на основі джерела [3]

Натомість, в Україні не існує дієвих механізмів стимулювання діяльності інноваційних підприємств та спостерігається критично низький рівень державного фінансування даної сфери. Так, у 2017 році частка витрат на НДР у ВВП становила всього лиш 0,45\% (середній показник країн СС-28 - 2,03\%), при чому за рахунок коштів ДБУ $0,16 \%$. До того ж, згідно зі статистичними даними, впровадження інновацій на підприємствах у 2017 році було фінансовано за рахунок коштів ДБУ лиш на 0,025\% (227,3 млн. грн.). [1]

Враховуючи досвід країн-лідерів з впровадження інновацій та реалії вітчизняної економіки, пропонуємо здійснити такі заходи, що сприятимуть активізації інноваційної діяльності підприємств:

1. Стабілізувати економічну та політичну ситуацію аби покращити інвестиційний клімат в Україні.

2.Запровадити ряд податкових стимулів для підприємств, що впроваджують інновації: звільнення від плати податку на прибуток протягом перших декількох років (залежно від розміру підприємства та типу новацій, що впроваджуються; періоду їх окупності), звільнення від місцевих податків та плати ССВ за робітників сфери НДДКР. А також, запровадити інвестиційний податковий кредит, надавати податкові канікули та знижки.

3. Оподатковувати за нижчою ставкою частину прибутку інноваційного підприємства, що буде спрямовуватися на інноваційні цілі. 
4.Надання пільгових кредитів для здійснення інноваційної діяльності: за нижчими відсотковими ставками або з відстрочкою платежів.

5. Усунення суперечностей в законодавстві, чітке виділення пріоритетних інноваційних напрямків діяльності, законодавче закріплення механізмів, що будуть спрямовані на захист прав інвесторів.

6. Підготовка висококваліфікованих кадрів у сфері впровадження інновацій, менеджерів з інноваційної діяльності.

7.Проведення активної співпраці 3 урядами інших країн та міжнародними організаціями стосовно передачі знань, методів виробництва та технологій.

На нашу думку, впровадження даних заходів дозволить підвищити рівень інноваційної діяльності підприємств зокрема та сприятиме розвитку національної економіки загалом.

\section{Список використаних джерел}

1. The report: «Global Innovation Index 2018» [Електронний ресурс]. - 2018. - Режим доступу до ресурсу: https://www.wipo.int/publications/ru/details.jsp?id=4330.

2. Водянка Л. Д. Зарубіжний досвід державного стимулювання інноваційної діяльності / Л. Д. Водянка, В. С. Підгірна, К. В. Сироїжко. // Економічна наука. - 2018. - №9. - С. 77-92.

3. Офіційний сайт Державної служби статистики України / Розділ: Наука, технології та інновації / Впровадження інновацій на промислових підприємствах [Електронний ресурс] - Режим доступу до pecypcy: http://www.od.ukrstat.gov.ua/stat_info/nauka.htm. 


\section{ОСОБЛИВОСТІ УЧАСТІ МЕРЕЖЕВИХ ФОРМ КОРПОРАТИВНОГО КАПІТАЛУ У МІЖНАРОДНИХ ЛАНЦЮГАХ ДОДАНОЇ ВАРТОСТІ}

У XXI ст. розвиток світових економічних відносин набув нового рівня, за якого все більш важливою умовою ефективної господарської діяльності стають розвинуті внутрішньофірмові та міжфірмові зв'язки. Компанії змінюють свою організаційну структуру для посилення іiі гнучкості та стійкості до зовнішніх умов. Особливо чутливими до екзогенних викликів сучасності $€$ бізнес-процеси, які пов'язані 3 глобальними ланцюгами доданої вартості, що створюються транснаціональними корпораціями. В сучасних умовах ланцюги доданої вартості стали головними елементами світової глобалізованої економіки. Зв'язки між ТНК та всередині них швидко розвиваються i розширюються, а їх значення в корпоративному секторі економіки помітно зростає, що актуалізує тему дослідження.

Основними суб'єктами здійснення економічних зв'язків в корпоративному секторі є глобальні, транснаціональні і національні корпорації різних галузей та сфер діяльності, а також, малий і середній бізнес, що підпорядкований корпоративному капіталу в системі кооперації і поділу праці. Зв'язки цих організаційно-економічних структур побудовані за принципом ієрархії та мережі.

Глобальні корпорації функціонують та розповсюджують свій вплив в масштабах всієї світової економіки, долаючи межі країн та їх об'єднань. Саме глобальні корпорації очолюють ієрархічну піраміду корпоративного капіталу. Вони здатні, використовуючи свій вплив та розгалужену систему зв'язків, контролювати стратегічно важливі сфери - фінанси, робочу силу, технології, постачання сировини тощо. Економічна потужність глобальних корпорацій перевершує можливості національних та регіональних економічних систем.

В умовах активізації діяльності ТНК та загострення міжнародної конкуренції поширення міжфірмових зв'язків стає поштовхом до поглиблення міжнародної економічної інтеграції та концентрації капіталу. Мережа дочірніх корпорацій та філій, а також малий і сердній бізнес потрапляе в залежність від глобального корпоративного капіталу, причому роль малих підприємств в міжнародних ланцюгах 
доданої вартості є надзвичайно важливою. В сучасних умовах основою господарства розвинених країн світу $є$ великі інтегровані корпоративні структури, навколо яких створюються мережі підприємств малого i середнього бізнесу.

Таким чином, однією з важливих форм виробничої інтеграції $\epsilon$ залучення малого та середнього бізнесу до системи корпоративного господарювання: «ТНК використовують малі фірми як субпідрядних постачальників, обслуговуючих агентств, дилерських фірм, що нерідко $\epsilon$ елементами широких мереж 3 гнучкою конфігурацією, яка змінюється для спільної вигоди самих корпорацій і великої кількості малих та середніх підприємств....» $[1$, с. 9]. В умовах сьогодення малий i середній бізнес є найбільш життєздатним, який має можливості впровадження гнучкої спеціалізації та інновацій. В умовах глобалізації, швидких технологічних змін та диверсифікації ринкових зв'язків відбувається криза традиційної корпоративної організаційної моделі, яка заснована на вертикальній інтеграції та ієрархічному управлінні. За таких умов великі корпорації намагаються змінити організаційну модель, стати більш гнучкими та здатними адаптуватися до змін зовнішнього середовища. Задля цього корпорації прагнуть посилити свій вплив і контроль над малим і середнім бізнесом, створити розгалужену мережу зв'язків 3 гнучкими інноваційними підприємствами, здатними швидко реагувати на потреби ринку.

М. Кастельс визначає мережу як «сукупність пов'язаних між собою вузлів» [2]. Мережеві організації - це сукупність фірм або спеціалізованих одиниць, діяльність яких координується ринковими механізмами, системою замовлень на постачання продукції та розвитком гнучких взаємовідносин 3 іншими фірмами на основі використання сучасних інформаційних технологій. Як зазначає Н. І. Гражевська: «Мережева структура є оптимальною для прийняття рішень у невизначеному середовищі внаслідок відкритості для інновацій, високої міри динамічності та адаптивності. Відтак капітал через «мережеву стадію» забезпечує впорядкування глобального корпоративного простору» [3, с. 266].

Основними учасниками сучасних мереж є такі гнучкі інноваційні підприємства, як «розумні» компанії, мережеві посередники, компанії по роботі з клієнтами, виробничі платформи, сервісні платформи тощо [4, с. 84-87]. Слід зазначити, що існування таких гнучких форм організації бізнесу та функціонування корпоративної власності в межах великих інтегрованих корпоративних структур жодним чином не виключає одне одне, а, навпаки, з'являються різноманітні форми 
співпраці глобальних корпорацій з гнучкими мережами малого i середнього бізнесу.

Організована мережа незалежних фірм, як вважає М. Кастельс, є переважаючою формою економічної активності в ринкових економіках Східної Азії. У Японії ділові групи організовані навколо мереж фірм із взаємною участю у власності, у яких головними компаніями керують менеджери. Існують два підтипи таких мереж. Перший - горизонтальні мережі, засновані на міжринкових зв'язках серед великих фірм. Ці мережі проникають у різні сектори економіки. До них відносяться такі корпорації, як «Mitsui», «Mitsubishi» та «Sumitomo». Другий тип вертикальні мережі побудовані навколо великої спеціалізованої індустріальної корпорації, яка охоплює сотні постачальників і пов'язані з ними філії. Основні мережі такого типу зосереджені навколо «Toyota Nissan», «Hitachi», «Toshiba», «Tokai Bank» i Промислового банку Японії [5, с. 176-177]. Ці структури практично контролюють ядро японської економіки, організувавши мережу взаємних зобов'язань, фінансової взаємозалежності, ринкових угод, обміну персоналом та інформацією.

Співпрацюючи з суб'єктами мережі, та розширюючи зв'язки 3 малим i середнім бізнесом, структура корпоративного капіталу одночасно залишається вертикально підпорядкованою, тобто ієрархічною. Залучаючись до розгалуженої мережі зв'язків, великі корпорації одночасно посилюють свій вплив і контроль над малим i середнім бізнесом, але не знищують його. У такий спосіб створюється гетерархічна структура, яка передбачає вертикальні і горизонтальні зв'язки між глобальними, транснаціональними, національними корпораціями, їхніми дочірніми підприємствами, філіями та дрібним бізнесом, за рахунок чого корпоративні структури зберігають свою життездатність в сучасних умовах.

Принцип гетерархії «не $\epsilon$ ні ринковим, ні ієрархічним. Тоді як ієрархія припускає відносини залежності, а ринки - відносини незалежності, гетерархія передбачає відносини взаємозалежності та ... характеризується мінімальним ступенем ієрархічності й організаційною гетерогенністю» [6, с. 120]. Термін «гетерархія» був введений в 1945 році неврологом Уорреном Маккаллоком. У ширшому контексті гетерархія визначається Д. Старком «як процес, у якому окремо взятий елемент (заява, угода, ідентичність, організаційний блок, структура генетичного коду, ...) одночасно відображається у безлічі мереж, що перетинаються» [6, с. 120]. Наприклад, малий i середній бізнес формує власні зв'язки і водночас в умовах сучасності є невід’ємною складовою ієрархії корпоративного капіталу. Тобто, 
вертикальні ієрархічні зв'язки між глобальними, транснаціональними, національними корпораціями, їхніми дочірніми компаніями та філіями, а також мережа горизонтальних зв'язків між різними організаційно-правовими формами в ієрархії корпоративного капіталу у сукупності є гетерархічною структурою, яка передбачає вертикальні і горизонтальні зв'язки одночасно.

Формування мереж за участі підприємств-субпідрядників займає особливе місце у сфері високих технологій. В сукупності дохід 10-ти найбільших підприємств-субпідрядників в галузі електроніки в 2017 році склав 201,5 млрд. дол. США. Серед замовників цих підприємств найбільші корпорації світу з виробництва електроніки такі, як «IBM», «Hewlett-Packard», «Dell», «Nokia», «Apple Inc», «Samsung», «Microsoft» та інші.

Мережеві зв'язки між корпораціями та малим і середнім бізнесом стають підгрунтям для збільшення ваги корпорацій на світовому ринку та посилення їх впливу на якість продукції та рівень цін. Корпорації, маючи величезні фінансові ресурси, в сучасних умовах намагаються всіляко сприяти розвитку дрібних гнучких суб' єктів мережі, оскільки усвідомлюють їхні можливості та ті потенційні переваги, які забезпечує малий і середній бізнес. Великі корпоративні структури не перешкоджають діяльності малих венчурних підприємств, а, навпаки, підтримують розвиток та знаходять оптимальні форми співпраці 3 ними. Підтвердженням цього $є$ те, що витрати філій закордонних ТНК в 2017 році на наукові дослідження і розробки в США склали 35,691 млрд. доларів США, в Японії - 8,012 млрд. доларів США [7].

Венчурне підприємництво $є$ важливим ланцюгом впровадження та підвищення ефективності реалізації інноваційних та інвестиційних програм ТНК. Венчурні фірми - це здебільшого малі підприємства у новітніх галузях виробництва (електроніка, біохімія, біоінженерія, виробництво споживчих товарів тощо), які швидко прогресують i працюють над розробкою і впровадженням інноваційних винаходів. Після впровадження винаходу ці підприємства або поглинаються більш великими фірмами, або шляхом продажу ліцензій зміцнюють свої фінансові позиції i на базі винаходів розгортають активну підприємницьку діяльність зі створення власного виробництва та організації комерційних операцій, як наприклад відомі американські фірми «Техаs Instruments», «Хеrox». Досить часто ініціаторами створення венчурних підприємств стають самі винахідники. Однак фінансуються вони, як правило, досить великими фірмами з числа найбільш зацікавлених у даних винаходах, наприклад «General Electric», «Boeing», «General Motors» та ін. Це пояснюється тим, що 
великі корпорації орієнтують свою діяльність на модернізацію своєї продукції з мінімальним ризиком. I хоча кожна 3 них має власні потужні науково-дослідні підрозділи, тим не менш, вважається за доцільне перекласти ризики, пов'язані з винахідництвом, на венчурні підприємства.

Часто малі інноваційні підприємства виступають в ролі доповнення до науково-дослідних комплексів крупних корпорацій. Наприклад, 3 такими американськими корпораціями, як «IBM», «General Motors», «Exxon», «Ford», тісно пов’язані декілька десятків тисяч невеликих фірм, які, зберігаючи юридичну самостійність, виступають субпідрядниками корпорацій в крупносерійному виробництві або постачальниками їм різного роду комплектуючих вузлів та деталей.

Таким чином, завдяки співпраці 3 дрібними інноваційними підприємствами, корпорації, надаючи їм нові можливості, натомість отримують новаторські нетрадиційні види діяльності, винаходи, наукові розробки, нові комбінації ресурсів, нові шляхи задоволення індивідуальних потреб та у такий спосіб посилюють свій вплив.

\section{Список використаних джерел}

1. Ульянов К. Є. Мережеві форми взаємодії фірм в епоху глобалізації / К. С. Ульянов // Формування ринкових відносин в Україні. - 2010. - №8 (111). - С. 8- 11.

2. Кастельс Мануель. Інтернет-галактика. Міркування щодо Інтернету, бізнесу і суспільства / Мануель Кастельс; пер. 3 англ. Е. Г. Ганиш, А. Б. Волкова. - К. : Ваклер, 2007. - 304 с.

3. Гражевська Н. I. Економічні системи епохи глобальних змін: монографія / Гражевська Н. І. - К. : Знання, 2008. - 431 с.

4. Камрасс Роджер. Алхимия корпорации. Как реформировать структуру бизнеса в соответствии с реалиями завтрашнего дня / Роджер Камрасс, Мартин Фарнкомб. - М. : «Секрет фирмы», 2005. $-254 \mathrm{c}$.

5. Кастельс Мануэль. Информационная эпоха: экономика, общество и культура / Мануэль Кастельс; пер. с англ. под науч. ред. О. И. Шкаратана. - М. : ГУ ВШЭ, 2000. - 608 с.

6. Старк Д. Гетерархия: неоднозначность активов и организация разнообразия в постсоциалистических странах / Д. Старк // Экономическая социология. - 2001. - Т. 2. - №2. - С. 115-132.

7. World Investment Report 2008: Investment and New Industrial Policies. - N.Y.; Geneva: United Nations, 2018. 
Стеценко Б.С.,

к.е.н., доцент,

ДВНЗ «Київський національний економічний університет імені Вадима Гетьмана»

\section{КОНКУРЕНТНА ПОВЕДІНКА ФІНАНСОВИХ ІНСТИТУЦЙ В ЕКОНОМЦЦ ЗНАНЬ}

Сучасний етап розвитку світової економіки характеризується суттєвими змінами в базових принципах економічних відносин. Серед іншого це стосується і посилення ролі знаннєвого фактору у функціонуванні різних економічних агентів. Дослідження позицій провідних вчених [1-3], дає можливість стверджувати, що для економіки знань характерні наступні ключові характеристики:

•нарощування частки сфери послуг у виробництві ВВП;

-прискорення темпів продукування, накопичення та використання знань в усіх без виключення сферах людського життя;

-докорінна зміна у технологіях та комунікаціях, що суттєво видозмінило кількісні та якісні параметри процесу виробництва та надання послуг, зокрема - в частині трансакційних витрат;

-мережевізація, цифровізація та інтелектуалізація економічних відносин;

•глобальне лідерство держав та компаній, що функціонують на засадах максимального застосування переваг економіки знань.

Зрозуміло, що є й інші позитивні характеристики економіки знань. Проте, зазначене вище не виключає того факту, що: по-перше, сучасна людська цивілізація перебуває на етапі переходу до цієї економічної формації (тобто мова йде скоріше про процес, а не про дійсність); подруге, іiї вплив є суперечливим з позиції різних економічних агентів. На останньому положенні акцентуємо додаткову увагу. Зміни, що притаманні економіці знань $є$ настільки радикальними, що вже зараз можна прогнозувати зникнення цілих секторів економіки, місце яких ще кілька десятиліть тому видавалося абсолютно непорушним. Не треба виключати і можливості спротиву 3 боку бізнес-одиниць «традиційних» галузей, особливо, якщо держава не приділяє достатньо уваги питанням формування сприятливого інституційного середовища.

Сучасний фінансовий сектор знаходиться «на вістрі» трансформацій, що притаманні глобальній економіці. Очевидно, що в 
повній мірі це стосується i взаємовідносин між фінансовими інституціями та іншими економічними агентами (насамперед, тут мова йде про споживачів фінансових послуг). Треба виходити з того, що фактор знань суттєво видозмінює відносини між суб' єктами сучасного фінансового ринку, особливо в частині класичних функцій, що притаманні фінансовому посередництву [4-5]: трансформація заощаджень в інвестиції, ефективний перерозподіл капіталу, економія на ефекті масштабу, модифікація та управління ризиками, ефективний відбір об’єктів інвестування.

На наш погляд, аналіз зазначених змін слід проводити на наступних рівнях:

- трансформація фінансових інституцій та фінансового посередництва у економіці знань;

- $\quad$ фінансові послуги та фінансові операції в економіці знань;

- формат відносин між різними учасниками фінансового ринку в економіці знань.

Зрозуміло, що як і для будь-якої компанії, поступове і невпинне формування економіки знань для фінансових інституцій визначає необхідність стратегічних змін. Більше того, саме для фінансових інституцій, виходячи з їх економічної природи, такі трансформації $\epsilon$ конче необхідними на сучасному етапі. Класична парадигма фінансового посередництва базується на визнанні того факту, що виникнення фінансових інституцій пов'язане з існуванням у власників заощаджень різноманітних перешкод в процесі їх індивідуального вкладання.

Найбільш значимі зміни, які зазнає фінансовий посередник в економіці знань, на наш погляд, виглядають наступним чином. Насамперед, відбувається ревізія класичних переваг, що їх надають фінансові посередники для своїх клієнтів. Наприклад, ще зовсім нещодавно однією із беззаперечних таких переваг було забезпечення доступу до ринку, на якому відбувалася торгівля фінансовими інструментами. Стрімка зміна комунікаційних технологій, розвиток цифрової та мережевої економіки, фактично нівелювала цей пункт. На сьогодні інвестор має справу 3 постійно діючим глобальним фінансовим ринком з масштабним характером операцій, які можна здійснювати незалежно від місця власного перебування. В свою чергу, все зазначене призвело до універсалізації фінансового посередництва (наприклад, появи т.з. «фінансових супермаркетів»), адже таким чином фінансові інституції намагаються втримати свої конкурентні позиції, надаючи широкий спектр послуг та операцій. Насамкінець, це 
визначило і докорінні зміни у доктрині державного регулювання фінансового сектору, в якій фактично не залишилося місця для поділу на банківськи орієнтовані та інші моделі.

Формування та накопичення знань у сфері обігу фінансових інструментів загострило питання про агентський конфлікт між фінансовими посередниками та споживачами їх послуг. Якщо раніше інституційні механізми давали можливість беззаперечно стверджувати про вищий професіоналізм осіб, які представляють фінансового посередника у відносинах із клієнтом, то зараз цю тезу часто можна поставити під сумнів.

Не можна оминути увагою той факт, що в умовах економіки знань фінансові інституції отримали явний поштовх до швидкого розвитку. Трансформація факторів виробництва у сучасній визначила і лідерство фінансового сектору за економічним потенціалом. Проте зростання масштабів фінансового посередництва багато в чому виглядає суперечливим, адже часто призводить до формування «фінансових бульбашок», які загрожують економічному розвиткові держави.

Питання про характеристики фінансової послуги в економіці набуває особливого змісту. Вітчизняним законодавством [6] визначені наступні параметри цієї дефініції: операція з фінансовими активами; здійснюється в інтересах третіх осіб; ціль - отримання прибутку або збереження реальної вартості. Використання знання суттєво видозмінює сутнісні сторони фінансової послуги. Насамперед в цьому контексті потребує аналізу питання про взаємовідносини фінансових інституцій та споживачів фінансових послуг в частині: а) формату взаємодії; б) рівня накопичених знань та ефективності їх використання.

Таким чином, внаслідок формування економіки знань змінюються принципи конкуренції у фінансовому секторі. Вже зараз суттєві конкурентні переваги отримують ті фінансові інституції, які максимізують вигоди від використання знаннєвих чинників у своїй діяльності. В середньостроковій перспективі така взаємозалежність буде лише посилюватися, що визначає і нові завдання в процесі розробки та реалізації корпоративних стратегій фінансових посередників.

\section{Список використаних джерел}

1. Геец В. М. Социально-экономические трансформации при переходе к экономике знаний. Сумы: ИТД «Университетская книга», 2004. $430 \mathrm{c}$.

2. Махлуп Ф. Производство и распространение знаний в США. М. : Прогресс, 1966. 462 с. 
3. Davenport T., Prusak L. Working Knowledge. Boston: Harvard Business School Press, 2000.

4. Пайк Р., Нил Б. Корпоративные финансы и инвестирование. СПб.: Питер, 2006. 784 с.

5. Зимовець В.В. Акумуляція фінансових ресурсів та економічний розвиток: монографія. К.: Ін-т економіки НАНУ, 2003. $314 \mathrm{c}$.

6. Закон України «Про фінансові послуги та державне регулювання ринків фінансових послуг» №2664-III від 12 липня 2001 p.

Уманців Г.В., к.е.н., доцент Київський національний торговельно-економічний університет Мартинів І.К., к.е.н., молодший науковий співробітник науково-дослідної частини Київський національний торговельно-економічний університет

\section{«ІНДУСТРІЯ 4.0»У КОНТЕКСТІ ІНТЕЛЕКТУАЛІЗАЦЇ̈ ЕКОНОМІЧНОГО РОЗВИТКУ}

Інтелектуалізація суспільства та сучасна концепція розвитку економіки уособлюють у собі Четверту промислову революцію. У 2011 p. на промисловій виставці в Ганновері вперше було представлено програму «Індустрія 4.0», в якій уряд Німеччини поставив завдання розширити застосування інформаційних технологій у виробництві 3 метою збереження і збільшення конкурентних переваг країни [1]. Саме поєднання сучасних інформаційно-комунікаційних технологій 3 промисловим виробництвом, важливими елементами нового типу виробництва чого $\epsilon$ кібер-фізичні системи, big data, штучний інтелект, 3D-друк, є характерними рисами «Індустрії 4.0» [2]. Розвиткові «Індустрії 4.0» передували три промислові революції (табл. 1).

\section{Таблиия 1}

\section{Промислові революції у світовій економіці}

\begin{tabular}{|l|l|}
\hline $\begin{array}{l}\text { Перша } \\
\text { промислова } \\
\text { революція }\end{array}$ & $\begin{array}{l}\text { Для механізації виробництва та впровадження верстатів та нових } \\
\text { технологічних процесів у хімічній та залізорудній промисловості } \\
\text { почали використовувати воду та пару }\end{array}$ \\
\hline
\end{tabular}




\begin{tabular}{|l|l|}
\hline $\begin{array}{l}\text { Друга } \\
\text { промислова } \\
\text { революція }\end{array}$ & $\begin{array}{l}\text { Винайдення електричної енергії спричинило зростання масового } \\
\text { виробництва і створило основу для вільного руху людей та ідей } \\
\text { завдяки розширенню комунальних, телеграфних та залізничних } \\
\text { мереж }\end{array}$ \\
\hline $\begin{array}{l}\text { Третя } \\
\text { промислова } \\
\text { революція }\end{array}$ & $\begin{array}{l}\text { Впровадження нових цифрових технологій, включаючи } \\
\text { персональні комп'ютери, мобільні телефони та Інтернет }\end{array}$ \\
\hline $\begin{array}{l}\text { Четверта } \\
\text { промислова } \\
\text { революція } \\
\text { «ндустрія 4.0» }\end{array}$ & $\begin{array}{l}\text { Перехід від звичайної автоматизації виробництва та використання } \\
\text { інформаційних технологій у виробництві до об'єднання у мережу } \\
\text { ресурсів, інформаційних потоків, об'єктів та людини }\end{array}$ \\
\hline
\end{tabular}

Джерело: складено авторами на основі [3; 4; 5; 6; 7]

Характерні «Індустрії 4.0» елементи виробництва зумовлюють збільшення витрат на процеси досліджень і розробок (НДДКР), тим самим активізуючи інноваційну діяльність на підприємствах усіх сфер та галузей, сприяють розвитку ринку інтелектуальної власності, виробництву продукції відповідно до вимог індивідуального замовника за допомогою оптимізації собівартості, покращенню якості автоматизації процесу виробництва. Як приклад, алгоритми штучного інтелекту на заводі Siemens використовують дані від фрезерних верстатів, щоб визначили, коли шпинделі машин досягають терміну служби та потребують заміни. Завдяки цьому компанія економить близько 10000 євро на машині кожного року, оскільки алгоритми штучного інтелекту дозволяють уникнути несанкціонованого простою [8].

За даними звіту «Readiness for the Future of Production Report 2018», складеного Світовим Економічним Форумом 3 метою визначення поточного рівня готовності країн до потенційних можливостей у процесі переходу до «Індустрії 4.0», досліджувані 59 країн згруповано за двома компонентами: структурою виробництва та драйверами виробництва. Кожна компонента включає чотири групи: провідні країн; країни «спадщини»; країни з високим потенціалом та країни, що зароджуються [9]. Саме двадцять п’ять провідних країн $\epsilon$ найбільш підготовленими до Четвертої промислової революції [10]. На основі аналізу в «Індустрії 4.0», проведеного «Industrie 4.0 in a Global Context: Strategies for Cooperating with International Partners» до економічних можливостей країн, належать оптимізація виробництва; формування нових бізнес-моделей; якість надання послуг споживачам; інтеграція інформаційних, комунікаційних та виробничих технологій $[5 ; 7]$. 
У процесі реіндустріалізації «Індустрія 4.0» відіграє дуже важливу роль. Так, виробничий сектор СС забезпечує понад 80\% експорту та 80\% приватних досліджень і інновацій [2]. За прогнозами Всесвітнього Економічного Форуму у майбутньому «Індустрія 4.0» призведе до створення не лише розумних будинків, а й розумних міст, безпілотних автомобілів на вулицях, штучного інтелекту в офісах [1]. Впровадження програм розвитку «Індустрія 4.0» характеризується досягнення значних результатів, які наведені у табл. 2. Досягнення таких результатів здійснюється різними шляхами, серед яких розроблення технологій наступного покоління (Італія, Великобританія); розроблення нових товарів та вдосконалення виробничих процесів (Німеччина, Італія); надання підтримки малим i середнім підприємствам для інноваційної діяльності та комерціалізації (Великобританія, Франція та Іспанія) [5; 7].

Впровадження програм розвитку «Індустрії 4.0» потребує великих інвестицій та значного фінансування. Так, у Німеччині урядом було виділено 200 млн. євро та отримано 300 млн. євро зі сторони бізнес сектору. Держава та бізнес своєю кооперацією та інвестуванням у розвиток Четвертої промислової революції можуть цілком розраховувати на отримання дивідендів. За оцінками консалтингової компанії Rolan Berger у разі виконання усіх вимог, що висуває перед країнами $\mathrm{CC}$ «Індустрія 4.0», потенційний прибуток може досягти 1,25 трильйонів доларів [1].

Таблиия 2

Досвід країни ЄС щодо впровадження «Індустрії 4.0»

\begin{tabular}{|c|c|c|}
\hline Країна & $\begin{array}{l}\text { Назва } \\
\text { проекту/стратегії }\end{array}$ & Досягнуті результати \\
\hline Німеччина & $\begin{array}{l}\text { Platform Industrie } 4.0 \\
\text { (на основі Хай-тек } \\
\text { стратегіï) (2011) }\end{array}$ & $\begin{array}{l}\text { Фінансування у розмірі } 200 \text { млн євро державних } \\
\text { коштів, приватне фінансування у співвідношенн } \\
\text { від } 2: 1 \text { до } 5: 1 \text {. Платформа налічує понад } 300 \\
\text { учасників, 200 проектів ( у т.ч. більше } 100 \\
\text { виробничих) }\end{array}$ \\
\hline Франція & $\begin{array}{l}\text { Alliance pour } \\
\text { l'Industrie du Future } \\
\text { (на основі стратегіï } \\
\text { «Нова промислова } \\
\text { Франція») (2015) }\end{array}$ & $\begin{array}{l}\text { Фінансування у розмірі } 10 \text { млрд євро державних } \\
\text { коштів та за рахунок підтримки приватного } \\
\text { сектору. Видано кредити для } 800 \text { компаній, } \\
\text { здійснено діагностику модернізації виробництва } \\
\text { більше } 3400 \text { компаніям }\end{array}$ \\
\hline \multirow[t]{2}{*}{ Італія } & $\begin{array}{lr}\text { Intelligent } & \text { Factory } \\
\text { Cluster } & \text { (CFI) } \\
\text { (Дорожня } & \text { карта } \\
\text { інновацій) } & (2012) \\
\end{array}$ & $\begin{array}{l}\text { Фінансування у розмірі } 34 \text { млн євро державних } \\
\text { коштів та } 11 \text { млн євро приватних. Створено } \\
\text { платформу співпраці, реалізовано чотири } \\
\text { пріоритетні дослідні проекти }\end{array}$ \\
\hline & $\begin{array}{l}\text { Національний план } \\
\text { Industria } 4.0 \text { (2017) }\end{array}$ & $\begin{array}{l}\text { Фінансування у розмірі } 18 \text { млрд євро державних } \\
\text { коштів }\end{array}$ \\
\hline
\end{tabular}




\begin{tabular}{|c|c|c|}
\hline Австрія & $\begin{array}{l}\text { Platform Industrie } 4.0 \\
\text { (засновники - } \\
\text { Міністерство транс- } \\
\text { порту, інновацій і } \\
\text { технологій Австрії та } \\
\text { кілька галузевих } \\
\text { асоціацій) (2015) }\end{array}$ & $\begin{array}{l}\text { Фінансування у розмірі } 300 \text { тис. євро щороку від } \\
\text { засновників, а також членські внески учасників } \\
\text { Платформи. Розширено мережу платформи } \\
\text { Індустрія } 4.0 \text { з } 6 \text { до } 41 \text { члена, розвиток співпраці } \\
\text { між бізнесом і наукою, } 80 \text { публікацій про } \\
\text { промисловість 4.0, створення бази даних } 3 \\
\text { відповідними стандартами та нормами }\end{array}$ \\
\hline Угорщина & $\begin{array}{l}\text { Ініціатива «I4.0 NTP) } \\
\text { (на основі стратегії } \\
\text { реіндустріалізації } \\
\text { Irinyi Plan) (2016) }\end{array}$ & $\begin{array}{l}\text { Фінансування за рахунок волонтерської роботи } \\
\text { науковців. У платформі близько } 70 \text { членів. } \\
\text { Підготовлено аналітичну робота про майбутне } \\
\text { Індустрії } 4.0 \text { в Угорщині }\end{array}$ \\
\hline
\end{tabular}

Джерело: складено авторами на основі [11; 12]

Головними суб' єктами на ринку в умовах Четвертої промислової революції стають інтегратори, стратапери, інноваційні центри та інноваційні бізнес-інкубатори. Розвиток «Індустрії 4.0» зумовлює також появу нових гравців на ринку. Так, наприклад, з'явилося поняття «вендор», під яким розуміють компанію-постачальника (зазвичай виробника) товарів та послуг під власною торговою маркою [13]. Німецька компанія IoT Analytics займається проведенням маркетингових досліджень ринку «Інтернет речей», М2М та «Індустрію 4.0», у своїй аналітичній довідці про провідних вендорів Індустрії 4.0 проводить дослідження у розрізі промислових компаній (тобто таких, що використовуються для створення рішення Connected Industry) та компаній, що належать до інших галузей (такі, що використовуються самостійно або разом з промисловими компаніями для реалізації напрямів «Індустрії 4.0»). За даними IoT Analytics, серед провідних вендорів промислових компаній можна знайти Amazon, Bosh, IBM, Google, Argus, Siemens. В свою чергу, Sony, Canon, Intel, Epson, Futjitsu належать до групи компаній інших галузей [14].

Таким чином, можна стверджувати, що політика впровадження «Індустрії 4.0» спрямована на зміцнення конкурентоспроможності і модернізацію економіки, а також на забезпечення сталого зростання виробництва, підвищення технологічного рівня на основі цифровізації. Це дає можливість інтегрувати горизонтальні та вертикальні ланцюги створення вартості, впровадити нові бізнес-моделі, пропонуючи значну додану вартість на основі індивідуальних рішень [5]. Спираючись на досвід країн СС щодо стимулювання розвитку «Індустрії 4.0», доцільно врахувати впровадження національних програм розвитку у цій сфері; передбачити об'єднання зусиль органів державної влади, науково-дослідних установ та бізнесу; сприяти залученню державних та приватних джерел фінансування. 


\section{Список використаних джерел}

1. Индустрия 4.0. - Електронний ресурс. - Режим доступу: https://www.it.ua/knowledge-base/technology-innovation/industry-4

2. Яка промислова політика потрібна Україні для переходу до Індустрії 4.0? - Електронний ресурс. - Режим доступу: https://www.civic-synergy.org.ua/articles-in-the-media/yaka-promyslovapolityka-potribna-ukrayini-dlya-perehodu-do-industriyi-4-0/

3. Buritt, R., Christ, K. Industry 4.0 and environmental accounting: a new revolution? // Asian Journal of Sustainability and Social Responsibility. - 2016. - Vol. 1. - P. 23-38

4. Budanov V. Industry 4.0: socio-economic junctures // Economic annals-XXI. - 2017. - № 168. - P. 33-37. - Електронний ресурс. - Режим доступу: http://nbuv.gov.ua/UJRN/ecchado_2017_168_8

5. Industrie 4.0 in a Global Context Strategies for Cooperating with International Partners / H. Kagermann,R. Anderl, J. Gausemeier, G. Schuh, W. Wahlster (Eds.); acatech Study. Herbert Utz Verlag GmbH, - 2016. - 74 p.

6. Industry 4.0 - Opportunities and Challenges of the Industrial Internet / R. Geissbauer, S. Schrauf, V. Koch,S. Kuge. PricewaterhouseCoopers Aktiengesellschaft Wirtschaftsprüfungsgesellschaft. - December 2014. - 52 p.

7. Сигида, Л.О. Індустрія 4.0 та їх вплив на країни світу [Електронний ресурс] / Л.О. Сигида // Економіка та суспільство. -2018. - №17. 는 Р - Роступу: http://www.economyandsociety.in.ua/journal/17_ukr/9.pdf

8. Future technologies that will drive Industry 4.0. - Електронний pecypc. - Режим доступу: https://www.weforum.org/agenda/2019/01/future-technologies-will-driveindustry-4-0/

9. Readiness for the Future of Production Report 2018. Insight Report. In collaboration with A.T. Kearney. World Economic Forum. 2018. - 266 p. - Електронний ресурс. Режим доступу: http://www3.weforum.org/docs/FOP_Readiness_Report_2018.pdf

10. Only 25 countries well-positioned to benefit from Industry 4.0 according to new World Economic Forum report. 13 Feb 2018. Електронний ресурс. - Режим доступу: https://www.edb.gov.sg/en/newsand-resources/insights/innovation/only-25-countries-wellpositioned-tobenefit-from-industry-4-0-a.html 
11. Digital Transformation Monitor «Germany: industrie 4.0». Електронний ресурс. - Режим доступу: https://ec.europa.eu/growth/toolsdatabases/dem/monitor/.../DTM_Industrie\%204.0.pdf

12. Digital Transformation Monitor «Key lessons from national industry 4.0 policy initiatives in Europe». Електронний ресурс. - Режим доступу: $\quad$ https://ec.europa.eu/growth/toolsdatabases/dem/monitor/sites/default/files/DTM_Policy initiative comparison v1.pdf

13. Словарь маркетолога. - Електронний ресурс. - Режим доступу:

http://www.marketch.ru/marketing_dictionary/marketing_terms_v/vendor/

14. The Leading Industry 4.0 Companies 2019. - Електронний peсурс. - Режим доступу: https://iot-analytics.com/the-leading-industry-40-companies-2019

Н.В. Ушенко, доктор економічних наук, професор, Національний авіаційний університет

\section{ПІДПРИЕМНИЦЬКА ТРАНСФОРМАЦІЯ УНІВЕРСИТЕТІВ УКРӒ̈НИ}

Розширення фінансових повноважень закладів вищої освіти України завершує повноправність їх функціонування в якості економічно повноцінних суб'єктів ринку. Надані права економічної автономії зумовлюють потребу чергового посилення у діяльності сучасних університетів підприємницької функції, що потребує запровадження комплексу заходів щодо концентрації зусиль навколо центрів створення вартості (прибутковості). У свою чергу це потребує зміни традиційних поглядів на систему управління та адміністрування, яка має спрямувати зусилля науково-педагогічних працівників та адміністративного персоналу на повний цикл формування вартісної цінності, що здатен стоврити конкретний університет з урахуванням індивідуального потенціалу.

Вчений-економіст В.Базилевич звертає увагу на роль університету, «..., адже він завжди постає справжнім осередком духовності та культури, задовольняючи одну з найвищих суспільних 
потреб - збереження і примноження інтелектуально-знаннєвого потенціалу суспільства, нації, людства» [1, с. 79-80]. М.Згуровський акцентує увагу на інноваційності університетів, що «всі успішні інноваційні системи світу об'єднані загальним принципом. В них університет $\epsilon$ не лише учасником інноваційного процесу, а й виступає його ядром. Він стає головним центром докладання державних зусиль i ресурсів для розвитку інновацій. Звичайно, дослідницький університет зберігає академічну складову, але при цьому працює одночасно по трьох взаємозалежних напрямах: навчання, наукові дослідження, інноваційне впровадження високих технологій та виведення їх на ринки чи технологічний трансфер» [2]. Проекція ринкових умов на загальноприйняті функції університетів обумовлюють його сучасне функціонування в якості суб'єктів інтелектуального підприємництва, які здатні запропонувати ринку освітні послуги, наукові дослідження, інновації. Перші дві складові автором ширше розкрито у ряді наукових публікацій [3;4], тому у даному дослідженні зосередимося на організаційній перебудові та адмініструванні ширшого впровадження підприємницького управління в діяльність сучасних університетів задля продукування інновацій.

Зарубіжні дослідники розрізняють знаннєве, академічне та інтелектуальне підприємництво [5], що ширше розкрито у науковій публікації Л.Шевченко [6]. Інтелектуальне підприємництво як концепція започаткована наприкінці 1990-х рр. та представляє собою поєднання інтелектуалізму, підприємництва й університетської (академічної) освіти [5], тому можна вважати інтелектуальне підприємництво самою широкою серед названих форм за функціональною змістовністю.

Першочергово слід звернути увагу на базову основу функціонування університету - їх суспільна роль у примноженні знань.

Ключовим лейтмотивом останньої Доповіді ЮНЕСКО з науки «На шляху до 2030 року» стало: «Численні дилеми, які стоять сьогодні перед багатьма країнами, схоже, набувають все більш загальний характер. До їх числа відноситься прагнення знайти рівновагу між місцевою i міжнародною участю в наукових дослідженнях, між фундаментальними і прикладними дослідженнями, між генерацією нових знань і виробництвом знань, що користуються попитом на ринку, між наукою в інтересах суспільного блага і наукою як рушійною силою комерційної діяльності» [7, с.2].

Слід зазначити, що сучасна підприємницька трансформація університету спрямована не тільки на фінансову капіталізацію, а 
першочергово базується на людському капіталі (знання, навички залучених викладачів, вчених, фахівців) та продовжує нарощувати людський капітал різних поколінь, що не менш важливо в умовах дефіциту кадрів належної якості. Зазвичай інноваційне підприємництво, яким і може бути підприємництво в освітньонаукових системах, асоціюється із креативністю, знаннєємністю, ризиковістю, технологічністю, комунікативністю, цифровою творчістю. Відповідно на окрему - особливу увагу заслуговують підприємницькі компетенції фахівців, які проявляються у здатності знаходити нові ідеї і перетворювати їх в бізнес. Також The Economist опублікував результати дослідження 19 бізнес-секторів в 26 країнах світу, і підприємницьке мислення було названо в числі найважливіших навичок сучасної людини, в результаті чого до перерахованих компетенцій додається здатність сприйняття ризиків, що лежить в основі бізнесової діяльності. Вважаю доречним акцентувати увагу на започаткування 32016 p. підготовки у закладах вищої освіти профільної у цьому контексті спеціальності 076 «Підприємництво, торгівля та біржова діяльність» як прикладної бізнес-економічної спеціальності, випускаюча кафедра якої і може долучитися до професійного сприяння у розвитку підприємницького мислення (навичок) зацікавлених викладачів та здобувачів освіти інших спеціальностей.

Оскільки основними учасниками інтелектуального підприємництва слід визнати вчених, викладачів, здобувачів вищої освіти, а організаційна складова може бути забезпечена фахівцями проектних офісів або інших структурних підрозділів, які організаційно сприяють результативності. Наприклад, у Національному авіаційному університеті відкрито перший на базі вишів Центр підтримки інновацій «TISC», основною ціллю якого $є$ надання винахідникам з країн, що розвиваються, віддаленого доступу до високоякісної технічної інформації і пов'язаними з нею послугами, дозволяючи новаторам розкрити свій потенціал, забезпечити охорону прав і управління ними. Його послуги в основному полягають у спрощеному пошуку та доступу до патентної, наукової та технічної бази даних, діагностуванні своїх розробок на предмет новизни, патентоспроможності, допомоги в ліцензуванні та трансфері технологій, розробці патентів задля головної кінцевої мети - комерціалізації винаходу. Саме такі функції комерціалізації та захисту інтелектуальної власності - являються провідними для підприємницького університету академічного типу та найбільш ймовірним варіантом для українських університетів, що і 
зараз вже можна констатувати їх приналежність до такого типу (за умови прибутковості їх діяльності та гідної оплати праці).

За аналітичними оглядом Економічного дискусійного клубу, освітня сфера $\epsilon$ не досить престижною з огляду на рівень оплати праці, оскільки у 2018 році в середньому могли розраховувати лише на 7041 грн. (219 євро) на місяць. У Росії та Польщі освіта також не належить до пріоритетних сфер за рівнем оплати (у 2018 році відповідно 432 і 1032 євро). А у Чехії оплата праці освітян знаходиться у першій половині зарплатного рейтингу та практично відповідає середньому рівню по економіці, в результаті чого є більшою у 5,6 рази у порівнянні 3 Україною [8].

Зважаючи на вищезазначене, благородна суспільна значимість інноваційного підприємництва не викликає сумнівів, але при цьому домінантними стримуючими факторами для підприємницької трансформації університетів залишаються:

- відсутність підприємницьких навичок та психологічне несприйняття підприємницького підходу у традиційному освітньому середовищі,

- складність суцільної комерціалізації у освітній та науковій складових університетів, що обумовлена приватною та суспільною цінністю можливих інноваційних розробок,

- відсутність належної мотивації у викладачів, що посилене зниженням статусності праці та низькою оплатою, несумісною із трудоємкістю та динамічністю змін та вимог її нового формату.

\section{Список використаних джерел}

1. Базилевич В.Д. Економічна наука та освіта в епоху системних трансформацій: нові виклики і запити до фундаментальної теорії. // Економіка України. - 2016. - №8 (657). - С.78-92.

2. Згуровський М.3. Університетська наука та інноваційний розвиток економіки: доповідь на Міжнародному інноваційному форумі країн СНД 27 вересня 2011 р. [Електронний ресурс] / М.3. Згуровський. - Режим доступу: http://kpi.ua/ru/1132-photo.

3. Ушенко Н.В. Неперервна освіта для інтелектуальної економіки: формальний та неформальний сегмент // Східна Європа: економіка, бізнес та управління. - 2017. - №1 (6). - С. 147-153.

4. Ушенко Н.В. Науково-дослідницький сектор закладів вищої освіти: проектний підхід інноваційного розвитку // Держава та регіони. - 2017. - №1 (94). - С. 86-91.

5. Abosede J. A. Intellectual Entrepreneurship: Theories, purpose and Challenge [Electronic resource] / J. A. Abosede \& A. B. Onakoya // 
International Journal of Business Administration. - 2013. - Vol. 4. № 5 5. 5 - $\quad$ Mode of access http://www.sciedu.ca/journal/index.php/ijba/article/view/3301/1954

6. Шевченко Л.С. Університети як суб'єкти інтелектуального підприємництва. [Електронний ресурс] // Теорія та практика правознавства. - 2014. - Вип. 1(5). Режим доступу: http://nbuv.gov.ua/UJRN/tipp_2014_1_9

7. Доклад ЮНЕСКО по науке: на пути к 2030 году [резюме] / ЮНЕСКО. - Изд-во ЮНЕСКО, 2015. - 44с.

8. Середні зарплати за видами економічної діяльності в Україні та окремих країнах світу / Економічний дискусійний клуб. - Режим доступу: http://edclub.com.ua/analityka/rubryka-cikavo-znatyseredni-zarplaty-za-vydamy-ekonomichnoyi-diyalnosti-v-ukrayini-ta.

Штундер I.O., к. е. н., доцент

Київський національний торговельноекономічний університет

\section{ІННОВАТИЗАЦІЯ ЗАЙНЯТОСТІ В УМОВАХ ЕКОНОМІЧНИХ ТРАНСФОРМАЦЙ}

Протягом тривалого періоду зайнятість в Україні характеризувалася значним тяжінням до індустріального суспільства другої половини XX століття. При цьому домінував тип зайнятості, що відповідав технологічному способу виробництва, який грунтувався переважно на ручній та механізованій праці. Мова йде про переважання трудової діяльності в промисловості, сільському господарстві та інших сировинних галузях, з широким застосуванням простої фізичної праці. Варто зазначити, що високорозвинуті країни пройшли цей етап ще у минулому столітті. Також слід зауважити, що рух у межах цієї парадигми, високий рівень тіньової зайнятості, наявність неформальних трудових відносин, істотне старіння населення, перманентні економічні кризи відкидали проблему інноватизації зайнятості на багато років назад. В умовах, що склалися 
на сучасному етапі мова може йти про культивування інновативноінформативного типу зайнятості, тобто такого, коли у складі працюючих осіб переважають люди, пов'язані зі збиранням, обробкою та наданням інформації у сфері виробництва, обігу та надання послуг. Не секрет, що межі ринку праці суттєво звужуються через сучасні науково-технічні досягнення. В перспективі більшість професій, пов'язаних з виконанням простих, монотонних, механічних функцій, які не потребують елементів творчості, швидше за все виконуватимуться за допомогою штучного інтелекту. Зокрема, мова йде про більшу частину професій, пов'язаних 3 інформацією i транспортом, продавців, операторів call-центрів, пілотів літаків, водіїв, листонош, касирів, бухгалтерів, екскурсоводів, перекладачів тощо [6].

Проте разом з тим сучасний ринок праці відкриває істотно нові можливості для тих працівників, які бажають і в змозі оперативно та мобільно пристосовуватися до його змін сьогодні та у майбутньому. На думку експертів, в близькій перспективі на ринку праці будуть користуватися істотним попитом фахівці з відновлення навколишнього середовища, урбаністи-екологи, агрокібернетики, дизайнери віртуальної реальності, нанолікарі, нанобібліотекарі [6].

В умовах інноватизації зайнятості спостерігається урізноманітнення iї форм прояву, а саме досить поширеними $\epsilon$ : маятникова, періодична, гнучка, вторинна зайнятість, лізинг персоналу, аутсорсинг персоналу, дистанційна зайнятість, робота в спеціально обладнаному офісі тощо. Зокрема, лізинг персоналу передбачає специфічну форму “оренди" персоналу на довгостроковій основі. Підприємство, що здійснює найм оплачує тільки послуги агентства-лізингодавця, не пов'язуючи себе зі співробітником юридичними відносинами. При цьому працівник юридично перебуває в штаті компанії-лізингодавця.

Temporary staffing як сучасна форма зайнятості передбачає набір персоналу на нетривалий період (до трьох місяців). Найчастіше $\epsilon$ потреба в таких послугах при проведенні маркетингових досліджень або виконанні дрібних короткочасних проектів. Підбір фахівця робить рекрутинговое агентство і воно ж несе відповідальність за співробітника.

Аутсорсинг персоналу (виробничий аутсорсинг, IT-аутсорсинг, аутсорсинг бізнес-процесів, атсорсинг управління знаннями, змінами) являє собою купівлю послуги певного фахівця, яка потрібна компанії на конкретний період часу. Перелік питань, який можна вирішити таким чином є досить великим. Як правило, це стосується вирішення завдань, не пов'язаних з профільною діяльністю компанії-замовника. 
Аутсорсинг дає можливість компанії-замовникові скоротити витрати i значно знизити трудомісткість i витрати на експлуатацію інформаційних систем, сконцентруватися на основних бізнес-процесах компанії, не відволікаючись на допоміжні [4].

Поряд 3 аутсорсингом поширеним $\epsilon$ аутстаффінг, який передбачає, що компанія приймає у свій штат вже працюючого в клієнтській компанії фахівця. При цьому відповідальність несуть обидві сторони, а формальні дії (оформлення трудової книжки, відрахування податків) бере на себе агентство-лізингодавець [2].

Сучасною формою зайнятості населення, яка вже добре себе зарекомендувала $\epsilon$ також і дистанційна зайнятість. Вона передбачає розосередження працівників по декількох місцях: частково на дому, частково в місцях, які є власністю роботодавця. Зазвичай таку роботу виконує кваліфікований працівник, що користується повною довірою роботодавця, а також професійний виконавський персонал. Здебільшого залучення до такого виду зайнятості регулюються колективним договором підприємства та персональними контрактами найманих працівників.

Робота в спеціально обладнаному офісі як сучасна форма зайнятості передбачає роботу на відстані та здійснюється на майданчиках роботодавця та субпідрядника. При цьому виробничі приміщення забезпечуються найновітнішими телекомунікаціями.

Сучасна цифрова економіка, використання штучного інтелекту, віртуальна реальність, значні обсяги електронних даних суттєво змінюють сучасну парадигму зайнятості населення. Серед зайнятих сьогодні в групі, яка ризикує втратити роботу у майбутньому знаходяться люди, що не в змозі прийняти нові реалії, не можуть або не хочуть опановувати нові digital-професії. За будь-яких умов сучасному працівникові доведеться працювати та співіснувати на виробництві зі штучним інтелектом, що приймає рішення за певним алгоритмом дій.

Економіка інноваційного типу, на нашу думку, розвиватиметься завдяки співпраці, обміну благами, використанню відновлюваних джерел енергії, вільному доступу до інформаційних мереж. Творча активність працівника, новаторство, постійне оновлення знань, опанування нових видів діяльності, реалізація успішних стартапів, соціальні інновації - ось та принципово нова концепція зайнятості в сучасних умовах. Водночас інноватизація зайнятості тягне за собою i низку загроз - це такі загрози як нестабільність зайнятості, відсутність постійного місця роботи, тимчасові підробітки, низька i часто ситуативна заробітна плата, зростання рівня безробіття, жорсткість 
ринкової конкуренції на ринку праці, правова незахищеність працівників [6].

В таких умовах надзвичайно важливим є стратегічне бачення майбутніх перспектив зайнятості в аспекті ii інноватизації. Пріоритетами, на нашу думку, мають бути інноваційні форми зайнятості, раціональні пропорції робочого часу та часу відпочинку, навчання протягом усього трудового життя, сприяння зайнятості людей літнього віку.

Інноватизація зайнятості, на нашу думку, неможлива без спільної участі держави, найманого працівника та роботодавця в процесах професійного розвитку, прогнозування нових професій, спеціальностей, продукування i впровадження інновацій, обміну новими ідеями, створення бізнес-інкубаторів, ринку консалтингових послуг, просування інноваційної активності як у державні та недержавні соціальні інститути, розвитку стартапів, бізнес-шкіл, технопарків, технополісів, забезпечення конкурентної винагороди за працю.

\section{Список використаних джерел}

1. Давидова I.О. Інноваційна зайнятість в аспекті іiі сутнісних характеристик [електронний ресурс] // Ефективна економіка [сайт]. 2015. - - № $5 . \quad 5 \quad-\quad$ Режим доступу: http://www.economy.nayka.com.ua/?op=1\&z=4041

2. Смельяненко Л.М. Формування та регулювання новітніх форм зайнятості в Україні / Л.М. Смельяненко // Український соціум. - 2015. - №1 (52). - С. 82-89.

3. Інноваційна активність: [Електронний ресурс] // Державна служба статистики України - офіц. веб-сайт. - Режим доступу: ukrstat.gov.ua/.

4. Інноваційна політика: Європейський досвід та рекомендації для України: у 2-х т. Том 1. Ключові особливості інноваційної політики в якості основи для розробки заходів сприяння інноваціям, що спрямовують Україну до заснованої на знаннях конкурентоспроможної економіки - порівняння ситуації в ЄС i Україні. - Проект СС «Вдосконалення стратегій, політики та регулювання інновацій в Україні». - К. : Фенікс, 2011. - 214 с.

5. Наукова та інноваційна діяльність України: [статистичний збірник]. К.: 2017. - 141с.

України - офіц. веб-сайт. - Режим доступу: ukrstat.gov.ua/. 
6. Новак І. Стратегія зайнятості для України: якими мають бути орієнтири? // Дзеркало тижня. - №43-44. - 2017.

Янчук А.Л., к.э.н., доцент Белорусский государственный экономический университет

\section{НАПРАВЛЕНИЯ ИННОВАЦИОННОГО РАЗВИТИЯ ГОСУДАРСТВ АСЕАН}

Распространение так называемой Четвертой промышленной революции дает, с одной стороны, значительные возможности развития стран и регионов, но, с другой стороны, приводит к возникновению серьезных экономических проблем. Несомненно только то, что она приведет к трансформации социальных, экономических и политических систем во всем мире.

Четвертая промышленная революция основана на использовании таких технологий, как: искусственный интеллект и машинное обучение, робототехника и новые формы автоматизации, мобильный интернет, внедрение интернета вещей, распределенных регистров, трехмерной печати, автономных транспортных средств, новых материалов, генной инженерии и т.д.

Преобразующее воздействие этой революции требует, чтобы страны тщательно определяли свою экономическую политику и приоритеты в национальном масштабе. Ряд правительств АСЕАН начали принимать ответные меры, например, программа «Таиланд 4.0» и Сингапурская инициатива «Умная нация» [1].

В 2014 году Сингапур представил свой стратегический план «Smart Mobility 2030». В нем основное внимание уделено внедрению инновационных и устойчивых решений для обеспечения большей мобильности населения. В рамках плана был предложен ряд инициатив:

- Сингапур с августа 2016 года разрешил испытания так называемых «автономных транспортных средств по требованию» (ODAV) в качестве службы мобильности. Предполагалось, что коммерческие услуги ODAV могут быть начаты в стране в 2018 году; 
- первая программа по обмену электромобилями в Сингапуре запущена в декабре 2017 года, к которой постепенно присоединятся 30 зарядных станций и 80 электромобилей;

- автономные автобусы длиной 12 метров с максимальной скоростью 60 км/ч, вмещающие 40 человек, смогут работать на фиксированных маршрутах в Сингапуре в 2020 году;

- в контролируемых зонах, например в Технологическом университете Наньянг, будут действовать многочисленные самоходные транспортные средства.

Следует отметить, что для получения преимуществ Четвертой промышленной революции потребуется мобилизация ресурсов не только в национальном, но и региональном масштабе, что приведет к изменениям в характере трансграничных отношений и экономическом взаимодействии стран. В ближайшее время региональные организации, в частности АСЕАН, будут все более активно помогать в формировании и управлении этими преобразованиями.

Хотя государства АСЕАН являются политически, экономически и социально разнообразными, однако Четвертая промышленная революция даст им ряд общих возможностей [2]:

- увеличение благосостояния;

- повышение производительности в результате внедрения инновационных технологий;

- значительное ускорение экономической интеграции;

- расширение возможностей для малых и средних предприятий;

- возможности для «технологического прыжка»;

- активное вовлечение отдаленных регионов в экономику;

- улучшение воздействия на окружающую среду;

- трансформация сельского хозяйства;

- улучшение доступа к здравоохранению;

- модернизация систем оповещения о стихийных бедствиях.

Наряду с возможностями, Четвертая промышленная революция принесет определенные проблемы в государства АСЕАН:

- потеря рабочих мест;

- неравенство и политическая нестабильность;

- окончание традиционной «Фабрики Азия»;

- концентрация рыночной власти у глобальных корпораций;

- большая подверженность и уязвимость для кибератак.

В рамках Четвертой промышленной революции значительно усиливается потребность в региональном сотрудничестве и сопутствующих ему преимуществах. Региональный подход к решению 
возникающих проблем может помочь АСЕАН реализовать возможности по следующим направлениям [2,3]:

- свободный обмен данными, которые являются основой всех новых технологий. Особое значение имеет возможность передачи и доступа к данным через границы. Физические лица, компании и правительства будут все больше полагаться на способность перемещать, обрабатывать и хранить данные по всей АСЕАН для предоставления услуг и получения конкурентных преимуществ. Однако трансграничный поток данных может также вызывать проблемы, особенно связанные с личной и конфиденциальной информацией. Вопросы безопасности, конфиденциальности и прав интеллектуальной собственности приобретают первостепенное значение;

- характер торговли и производства. Происходит смещение от физических к виртуальным товарам. Вместо того, чтобы импортировать и экспортировать готовые товары, компании могут продавать чертежи и проекты, а клиенты используют трехмерную печать для их производства на месте;

- стандартизация обслуживания. Трансграничная торговля услугами также меняется. «Облачные» сервисы могут обеспечить возможности для предоставления необходимых услуг гражданам ACЕАН, особенно в отдаленных районах, по доступным ценам;

- гармонизация бизнес-среды. Компании АСЕАН (такие как банки, платежные фирмы, интернет-рынки, поставщики логистических услуг) должны будут работать в региональном масштабе. Гармонизация законов и положений между странами АСЕАН, содействие открытому доступу будут иметь существенное значение для обеспечения конкурентоспособности предприятий;

- переосмысление фискальной политики. Поскольку продукты становятся виртуальными, а услуги переходят в Интернет и предоставляются удаленно, то это изменяет действенность правительств по взиманию налогов;

- инновационные инкубаторы. Во многих странах АСЕАН уже есть инновационные центры и инкубаторы на национальном уровне. Однако для обеспечения конкурентоспособности новые предприятия должны будут работать в масштабе всего региона;

- региональные образовательные сети. Навыки, необходимые для устойчивой конкурентоспособности, будут сосредоточены не только на технических возможностях, но и на творческих и инновационных решениях проблем. Расширение существующей системы взаимодействия между университетами АСЕАН поможет построить 
трансграничные сети, что будет иметь решающее значение для подготовки будущих специалистов;

- снижение барьеров для мобильности рабочей силы. Снижение препятствий для мобильности квалифицированных рабочих в регионе будет способствовать удовлетворению этого спроса. Это может потребовать расширения существующих соглашений о взаимном признании профессиональной квалификации с включением новых профессий.

Таким образом, образование, технологическое развитие и инновационный потенциал являются теми факторами, которые позволяют странам занимать высокие позиции не только в регионе, но и в глобальном масштабе. Развитие и распространение Четвертой промышленной революции ведет к существенным изменениям в мировых экономических отношениях. Использование возникающих преимуществ и противостояние угрозам в рамках таких отношений возможно только при условии мобилизации всех ресурсов, в том числе человеческого потенциала, не только на национальном, но и региональном уровне. Инновации будут способствовать активизации инклюзивного роста, когда все слои населения даже в самых отдаленных районах АСЕАН смогут участвовать в принятии экономических решений и реализовывать свой потенциал с помощью удаленного доступа, что позволит повысить устойчивость экономики региона.

\section{Список использованных источников}

1. WEF. Human Capital Outlook: Association of Southeast Asian Nations (ASEAN) // World Economic Forum. - Geneva, 2016. Mode of access: http://www.weforum.org/reports/human-capitaloutlook-association-of-southeast-asian-nations. - Date of access: 10.09.2018.

2. WEF and ADB. ASEAN 4.0: What does the Fourth Industrial Revolution mean for regional economic integration? // World Economic Forum, Asian Development Bank. - Geneva, 2017. Mode of

http://www3.weforum.org/docs/WEF_2017_ASEAN4IR.pdf Date of access: 10.09.2018.

3. WEF. Shaping ASEAN's Future Readiness: Collaborations to Advance Manufacturing and Production // World Economic Forum. - Geneva, 2018. - Mode of access: http://www.weforum.org/whitepapers/shaping-asean-s-futurereadiness - Date of access: 10.09.2018. 


\section{НАУКОВИЙ НАПРЯМ З. МАКРО- ТА МІКРОЕКОНОМІЧНІ ПРОБЛЕМИ РОЗВИТКУ}

Бубон Т.В., викладач, КПІ ім. Ігоря Сікорського

\section{ТАЙМ-МЕНЕДЖМЕНТ ЯК ТЕХНОЛОГІЯ РОЗВИТКУ ОРГАНІЗАЦЇ̈}

Відомий американський промисловець Генрі Форд говорив, що час не любить, коли його витрачають даремно. Багато відомих фахівців, підтверджують цю істину, говорячи, що час - це такий специфічний ресурс, який в організації стоїть поряд 3 основними фондами, робочою силою, сировиною, але має особливу специфічну властивість - він $є$ незворотнім. I якщо обладнання можна придбати, сировина і матеріали теж не є рідкісним товаром, який необхідно довго розшукувати, то втрачений час неможливо повернути, неможливо реалізувати втрачені в цей час можливості, неможливо вирішити справи, якщо умови, в яких вони вирішуються помінялися.

В економіці XXI століття в зв'язку зі зростанням темпів змін і ступеня невизначеності економічного середовища збільшується потреба у підвищенні адаптивності організації, швидкості іiі реакції на зміни. Ця адаптивність стає одним 3 найважливіших чинників конкурентоспроможності організації як економічної системи. Одним 3 інструментів підвищення адаптивності економічної системи $\epsilon$ впровадження технологій тайм-менеджменту як елементу системи управління організацією.

Для організацій стає нормою, а не рідкісним винятком, спрямованість на інновації: розробка нових продуктів, вихід на нові ринки, впровадження нових технологій управління. Для топменеджерів і фахівців організації, відповідно, стає нормою постійне збільшення кількості та обсягу вирішуваних завдань, необхідність постійно знаходити резерви часу для здійснення проектів, що дозволяють організації безперервно розвиватися.

Зазначені потреби сучасних організацій зумовили необхідність впровадження централізованого тайм-менеджменту в системі управління організацією. 
Термін «тайм-менеджмент» застосовується для позначення технології управління, яка сформувалася в самостійний напрям менеджменту організації в 70-х p.p. XX століття. Тайм-менеджмент включає в себе всю сукупність технологій планування роботи співробітника організації, які застосовуються самим працівником для підвищення ефективності використання свого робочого часу та забезпечення підконтрольності зростаючого обсягу завдань. Іноді для позначення таких технологій застосовуються також терміни «самоменеджмент», «персональна (особиста) організація праці».[1, c.62].

В останні роки все більша кількість організацій усвідомлює потребу в централізованому впровадженні технологій таймменеджменту. Ця потреба обумовлена тим, що зростаючі темпи змін середовища вимагають передачі співробітникам організації більших повноважень, прийняття ними самостійних рішень, самостійної організації та планування своєї роботи. Особливо це актуально для мультипроектної діяльності, при великій кількості зовнішніх запитів, спрямованих безпосередньо до співробітника. Такі умови вимагають від працівника вміння самостійно визначати пріоритети в умовах обмеженого ресурсу часу.

Зростання ефективності та питомої ваги нематеріальних активів у вартості організації перетворює їх на основний чинник успішності компанії. За рахунок зменшення зовнішнього контролю за діяльністю працівника, підвищується рівень самостійної організації співробітником власної діяльності, яка набуває творчого характеру.

Проблема дефіциту часу часто виникає зовсім не від того, що в добі тільки 24 години, а від невміння ці години раціонально розподілити. Людина, яка вміє ефективно розпоряджатися своїм часом, завжди більш успішна, більшого доб'ється в житті і в кінцевому підсумку зможе повніше реалізувати себе. Причини, що викликають брак часу в роботі менеджерів, можна поділити на зовнішні, які обумовлені впливами навколишнього середовища і не залежать від особистих якостей i здібностей керівника (нагромадження робіт, неефективний інформаційний обмін, слабка зовнішня мотивація праці, безплановість роботи та ін.), і внутрішні, що залежать від особистісних характеристик керівника, таких як особливості темпераменту, організованість, самодисципліна, схильність до самоаналізу, вміння визнавати свої помилки. I саме тайм-менеджмент надає можливості досягати результатів в житті, завдяки вмінню виділяти пріоритети, бачити загальну картину, уникати стресів, забезпечувати високий рівень енергії, виконувати власні обіцянки, створювати основу для 
делегування, підвищувати свій потенціал, досягати рівноваги в своєму житті та ін.

Часто трапляються моменти, коли виникає нестерпне бажання розсунути часові межі, зробити добу більш наповненою і місткою. На жаль це не можливо. Варто замислитися, чи потрібні ці додаткові години, адже деяким людям часу не вистачить все одно. Проблема криється не в дефіциті часу, а у відсутності вміння керувати ним, використовуючи можливі прийоми, здатні надати високі результати.

Перш ніж говорити про роль тайм-менеджменту у підвищенні корпоративної ефективності та організаційного розвитку, потрібно зауважити, що в сучасній теорії та практиці термін «тайм-менеджмент» використовується для означення технологій управління часом в двох cферах.

Перша - сфера управлінських технологій, безпосередньо пов'язаних з управлінням часом на підприємстві, стосується систем управління організації. Основна увага тут приділяється організації роботи системи в цілому, а ефективне використання часу кожного окремого працівника стає наслідком правильно побудованої системи. У наш час за цей напрям «відповідають» реінжиніринг бізнес-процесів, проектний менеджмент, і т.П. Це, безумовно, технології «керування часом». Проте, керувати часом неможливо, можна керувати організацією певної діяльності, для якої найважливішим цільовим показником $є$ саме часові параметри.

Друга сфера застосування тайм-менеджменту - організація власної роботи, яку людина здійснює за власним бажанням, не воліючи витрачати марно невідновних ресурсів свого часу, а в кінцевому підсумку - свого життя. У руслі цієї лінії лежить тайм-менеджмент у вузькому сенсі слова, а також різні технології особистісного зростання. $[2$, c.47]

Отже, тайм-менеджмент, має як мінімум два різновиди. «Особистісний» тайм-менеджмент, завдяки своїм глибоким i не очевидним, на перший погляд, властивостям виявляється досить сильним двигуном не тільки особистої ефективності, а й ефективності організації. Тобто, при грамотному застосуванні прийомів та технік «системного» тайм-менеджменту можна 3 наростаючою силою впливати і на ефективність діяльності усього колективу. Такий підхід до підвищення ефективності може виявитися досить корисним для проведення масштабних організаційних перетворень.

На сьогодні більшість організацій підтримують розвиток таймменеджменту. Задля цього створюють навіть окремі посади. Це пов'язане з величезними перевагами, які надає тайм-менеджмент. Слід 
відмітити, що економія часу, як правило, виражається у грошовому еквіваленті. Якщо підлеглі будуть працювати скоріше, це не тільки підвищить швидкість виконання роботи, але i заощадить кошти роботодавцю. Також зменшення часу на виконання робочих завдань дає можливість збільшити час на спілкування 3 потенційними клієнтами, а це, в свою чергу, прогнозує практично лінійне збільшення обсягу продаж або кількості наданих послуг. Таким чином, впровадження тайм-менеджменту в організаціях являється складовою системи ефективного управління, оскільки це дає змогу раціонально використовувати робочий час $\mathrm{i}$, як наслідок, підвищувати продуктивність праці як окремої людини, так і всієї організації в цілому.

\section{Список використаних джерел}

1. Колесов О.С. Тайм-менеджмент - управління часом / О.С. Колесов, А.В. Вацьківська // Збірник наукових праць ВНАУ - 2011. - №.2(53). - T.3. - C.61-70.

2. Дункан Т. М. 8 ловушек времени. Как вырваться из порочного круга постоянно увеличивающейся загрузки на работе / Тодд М. Дункан; [пер. с англ. В. И. Кузина; науч. ред. Т. Н. Жукова]. — М. : Эксмо, 2008. — 224 с. — (Бизнес-бестселлер).

Весперіс С.3., к. е. н., доцент Конотопський інститут Сумського державного університету Самусь Г.І., к. е. н., викладач Конотопський інститут Сумського державного університету

\section{СУЧАСНИЙ СТАН АГРАРНОГО РИНКУ УКРАЇНИ}

Як відомо аграрний ринок країни поєднує в собі безпосередніх виробників та споживачів сільськогосподарської продукції, а також посередників. Центральною ланкою (суб'єктом) аграрного ринку виступають сільськогосподарські виробники всіх типів. Головною метою їх господарської діяльності $€$ підтримка своєї конкурентоспроможності та отримання максимального прибутку, задовольнивши при цьому потреби споживача. 
Виробниками сільськогосподарської продукції України на сьогоднішній день є державні підприємства, приватні фермерські господарства, сільськогосподарські кооперативи, товариства 3 обмеженою відповідальністю, особисті селянські господарства.

Станом на початок 2018 p. вони використовували для господарської діяльності 68,7 \% земель із загальної земельної площі України [2, с.65 ].

У регіональному розрізі у 2017 p. найбільші площі сільськогосподарських угідь припадали на Одеську (2591,6 тис. га), Дніпропетровську (2511,5 тис. га), Харківську (2411,3 тис. га) області, що свідчить про їх визначне місце на аграрному ринку. Найменші площі сільськогосподарських угідь припадали на Івано-Франківську (629,9 тис. га), Чернівецьку (469,7 тис. га) та Закарпатську (451,3 тис. га) області [2, с.66 ].

Розподіл суб'єктів господарювання за організаційно-правовими формами відображено в таблиці 1 . Аналіз даних таблиці 1 свідчить про скорочення у період з 2014 р. по 2017 р. на аграрному ринку таких суб'єктів господарювання як господарські товариства, приватні підприємства, кооперативи, державні підприємства. У той же час за досліджуємий період зросла кількість фермерських господарств на $3,3 \%$ [2, с.171]. Це свідчить про визнання даної форми господарювання на аграрному ринку України.

Усі суб'єкти господарювання постачають споживачам сільськогосподарську продукцію, забезпечуючи продовольчу безпеку країни. Аналіз структури продукції сілського господарства свідчить про подальшу тенденцію збільшення частки рослинництва 3 61,5\% до $72 \%$ та скорочення частки тваринництва з 38,5\% до 28\% у період з 2000 p. по 2017 р. [2, с.47]. Це призводить до нестачі власної продукції тваринництва на ринку та необхідності його імпорту. 
Таблиця 1

Розподіл суб'сктів господарювання за організаційно-правовими формами

\begin{tabular}{|c|c|c|c|c|c|c|c|c|c|}
\hline \multirow{3}{*}{$\begin{array}{l}\text { Організаційно- } \\
\text { правові форми } \\
\text { господарюванн } \\
\text { я }\end{array}$} & \multicolumn{8}{|l|}{ Роки } & \multirow{3}{*}{$\begin{array}{l}2017 \mathrm{p} . \\
\text { у \% до } \\
2014 \mathrm{p} .\end{array}$} \\
\hline & \multicolumn{2}{|c|}{2014} & \multicolumn{2}{|c|}{2015} & \multicolumn{2}{|c|}{2016} & \multicolumn{2}{|c|}{2017} & \\
\hline & од. & $\%$ & од. & $\%$ & од. & $\%$ & од. & $\%$ & \\
\hline Всього & $\begin{array}{c}4619 \\
9\end{array}$ & $\begin{array}{c}100, \\
0\end{array}$ & $\begin{array}{c}4537 \\
9\end{array}$ & 100 & $\begin{array}{c}4769 \\
7\end{array}$ & $\begin{array}{c}100 \\
0\end{array}$ & $\begin{array}{c}4555 \\
8\end{array}$ & 100 & 98,61 \\
\hline $\begin{array}{l}\text { Господарські } \\
\text { товариства }\end{array}$ & 7750 & 16,8 & 7721 & $\begin{array}{c}17, \\
0\end{array}$ & 8700 & 18,2 & 6967 & $\begin{array}{c}15, \\
3\end{array}$ & 89,90 \\
\hline $\begin{array}{l}\text { Приватні } \\
\text { підприємства }\end{array}$ & 3772 & 8,2 & 3627 & 8,0 & 3752 & 7,9 & 3215 & 7,1 & 85,23 \\
\hline Кооперативи & 674 & 1,4 & 596 & 1,3 & 738 & 1,5 & 448 & 1,0 & 66,47 \\
\hline $\begin{array}{l}\text { Фермерські } \\
\text { господарства }\end{array}$ & $\begin{array}{c}3308 \\
4\end{array}$ & 71,6 & $\begin{array}{c}3230 \\
3\end{array}$ & $\begin{array}{c}71, \\
2\end{array}$ & $\begin{array}{c}3368 \\
2\end{array}$ & 70,6 & $\begin{array}{c}3413 \\
7\end{array}$ & $\begin{array}{c}74, \\
9\end{array}$ & $\begin{array}{c}103,1 \\
8\end{array}$ \\
\hline $\begin{array}{l}\text { Державні } \\
\text { підприємства }\end{array}$ & 228 & 0,5 & 241 & 0,5 & 222 & 0,5 & 199 & 0,4 & 87,28 \\
\hline $\begin{array}{l}\text { Інші форми } \\
\text { господарюванн } \\
\text { я }\end{array}$ & 691 & 1,5 & 891 & 2,0 & 603 & 1,3 & 592 & 1,3 & 85,67 \\
\hline
\end{tabular}

Джерело: складено і розраховано авторами на основі [2, c.171].

Основними сільськогосподарськими культурами із частки продукції рослинництва на Україні у 2017 р. традиційно залишаються зернові та зернобобові $(26,2 \%)$, технічні $(22,5 \%)$, картопля та овочевобаштанні культури (18,0\%). У тваринництві лідирували вирощування сільськогосподарських тварин (13,5 \%), виробництво молока $(10,5 \%)$, яєць $(2,9 \%)$ [2, с.48]. Така видова структура продукції сільського господарства пояснюється потребами споживача та наявністю сприятливих факторів для іiї виробництва.

Сільськогосподарська продукція у 2017 р. вироблялася в основному $(56,4 \%)$ сільськогосподарськими підприємствами, із них 8,7\% приходилось на фермерські господарства [2, с.55 ].

Аналізучи стан сільського господарства слід відмітити зростання частки капітальних інвестицій на 5,7\% 32014 р. по 2017 р. (табл. 2), що 
свідчить про зростання інвестиційної привабливості галузі. Це позитвний фактор тим паче, що аграрний сектор потребує впровадження інноваційних технологій, що можливо лише за сприятлового інвестиційного клімату.

Таблиця 2.

Капітальні інвестиції у сільське, лісове та рибне господарство (у фактичних цінах; мільйонів гривень)

\begin{tabular}{|l|c|c|c|c|}
\hline Роки & 2014 & 2015 & 2016 & 2017 \\
\hline Усього & 219420 & 273116 & 359216 & 448462 \\
\hline $\begin{array}{l}\text { Інвестовано млн. грн. у } \\
\text { сільське, лісове, рибне } \\
\text { господарство }\end{array}$ & 18796 & 30155 & 50484 & 64243 \\
\hline $\begin{array}{l}\text { Частка від загальних інвестицій } \\
\text { на рік, у відсотках }\end{array}$ & 8,6 & 11,0 & 14,1 & 14,3 \\
\hline
\end{tabular}

Джерело: складено авторами на основі [2, с.23].

Слід також зазначити, що прибавити інвесторів може прийняття Україною норм і стандартів СС та впровадження безмитної торгівлі, що дасть можливість країні стати експортером продукції, а не сировини [1, с.166 ]. Це зміцнить позиції України на світовому аграрному ринку.

Фінансові результати діяльності сілськогосподарських підприємств до оподаткування свідчать про значні коливання данного показника: 2010 р. - 17320,5 млн. грн., 2013 р. - 15012,7 млн. грн., 2014 p. - 21495,9 млн. грн., 2015 р. - 101996,1 млн. грн., 2016 р. $-90122,1$ млн. грн., 2017 р. - 78786,1 млн. грн. Як видно, періоди підйому чергувалися з періодами падіння. Аналогічна тенденція характерна $\mathrm{i}$ для рівня рентабельності та інших фінансових результатів. Так, підприємства, які одержали прибуток до оподаткування у 2017 р. склали 86,7 \%, тоді як у 2015 р. цей показник становив 89 \% [2, с.174 ]. Отже, в діяльності сільськогосподарських підприємств склалася досить непроста ситуація. Також, потрібно враховувати і фактор ризику, що характерний для діяльності зазначених суб'єктів господарювання.

Отже, на аграрному ринку України присутні різноманітні організаційно-правові суб'єкти господарювання. Відмічено зростання кількості фермерських господарств країни, як наслідок саме вони виступають основними виробниками сільськогосподарської продукції. У структурі аграрного виробництва спостерігається подальша 
тенденція зростання частки рослинництва та скорочення тваринництва, що потребує значного корегування на державному рівні, в тому числі для покращення ринкової кон'юнктури. Аграрний ринок країни потребує значних інвестицій, що розширить можливості для інноваційної діяльності. Це дозволить покращити фінансові результати діяльності сільськогосподарських підприємств, зробить їх більш рентабельними та конкурентоспроможними.

\section{Список використаних джерел}

1.Залюбінська Л. М. Перспективи розвитку аграрного ринку України за умов євроінтеграції/Л.М.Залюбінська, М.Л.Скорик // Науковий вісник Ужгородського національного університету. -2018 - Випуск 20, частина 1. - С. 163-166

2.Сільське господарство України 2017 рік / Державна служба статистики України; відп. За випуск О.М.Прокопенко - К. [б/в], 2018. $-245 \mathrm{c}$.

Гаращенко Е.А., Белорусский государственный экономический университет

\section{СООТНОШЕНИЕ ТАРИФНОГО И НЕТАРИФНОГО РЕГУЛИРОВАНИЯ ВНЕШНЕЙ ТОРГОВЛИ СТРАН}

В экономической литературе выделяют современные особенности в сфере регулирования международной торговли: сокращение тарифных ограничений; расширение номенклатуры иных, нетарифных инструментов. Данная закономерность была также выявлена из аналитического и статистического учета специалистами Всемирного банка на основе данных ЮНКТАД.

При этом в мировой экономике не выявлено единого подхода к определению нетарифных методов регулирования. Теоретические аспекты, методологические особенности, классификацию данных мер регулирования в свое время пытались предложить ученые различных стран. Тарифными методами регулирования торговли также занимались отдельные ученые. Однако, учитывая теоретическую простоту, ясность и однозначность применения относительно Гармонизированной системы кодирования товаров, данный тип 
барьеров имеет более строгую и четкую методологическую основу и классификацию.

Не смотря на достаточно большое количество научных трудов по мерам тарифного и нетарифного регулирования внешней торговли стран, в литературе отсутствует четкое соотношение данных типов регулирования торговли. Отсутствуют данные исследования и у специалистов международных организаций.

Ocобое значение в правовой регламентации применения нетарифных ограничений, унификации их применения принадлежит ГАТТ, впоследствии ВТО. Первая классификация, разработанная Секретариатом ГАТТ к настоящему времени насчитывает более 800 видов нетарифного регулирования и объединяет их в пять основных категорий [1]:

- Ограничения, вызванные участием государства во внешнеторговых операциях.

- Таможенные и иные административные формальности.

- Технические барьеры в торговле (стандарты и требования экологического, санитарного, ветеринарного характера).

- Количественные и сходные с ними административные меры (квоты, экспортные ограничения, лицензирование, добровольные ограничения экспорта).

- Ограничения экономического характера (налоги, сборы, антидемпинговые и компенсационные пошлины).

В данной классификации был принят минимальный подход к определению на группы мер нетарифного регулирования и со временем он был модернизирован уже в ВТО.

На основе данного определения был сформированперечень нетарифных мер регулирования, достаточно часто применяемый во время переговоров по всем видам ограничений и являющийся основойприизучении, формирования, разъяснениивидов нетарифных барьеров иными международными институтами (ОЭСР, ЮНКТАД, Всемирный Банк).

Международная классификация нетарифных мер регулирования включает в себя 16 глав (от А до Р), каждая из которых делится на группы с кодированием до трех уровней. Хотя несколько глав достигают трехзначного уровня классификации, большинство из них ограничиваются двузначным определением.

Современная трактовка мер нетарифного регулирования некоторыми исследователями упрощается до трех укрупненных групп $[3,4,7]$.Первая группа - инструменты регулирования импорта (квоты, лицензии), вторая группа - инструменты регулирования экспорта 
(экспортные субсидии, экспортные запреты, добровольные ограничения экспорта), третья - инструменты «навязывания» национальной экономикой (экологические стандарты, внутренние налоги, сборы).

Киреев А.П. предлагает классификацию путем деления также на три группы: количественные, финансовые, скрытые[3].

ОЭСР провела исследование в области нетарифных ограничений, которое дает представление о диапазоне, сложности, дифференциации данного вида регулирования. Особенностью исследований ОЭСР является тот факт, что специалистами учитываются размер страны, уровень развития экономики, доход на душу населения и т.д. И была выявлена закономерность более широкого распространения нетарифных мер регулирования при торговле между развивающимися странами.

Профессор Давыденко Е.Л. выделяет наиболее общие две группы нетарифного регулирования:

1.Меры прямого ограничения, связанные с количественным контролем.

2. Меры косвенного ограничения, носящие неколичественный характер [6].

В экономической и юридической литературе не рассматривается понятие «система тарифного регулирования». Изучив эволюцию развития тарифного регулирования, целесообразно утверждать, что в современных условиях (к.XX-н.XXI)можно говорить о формировании системы тарифного регулирования, что позволит конкретизировать, систематизировать, обозначить значимость данной системы в мировой экономике. Подобное выделение ее из окружающей международной среды определит систему тарифного регулирования как самостоятельную, обособленную совокупность элементов государственного регулирования внешнеторговой деятельности страны, которая включает в себя тарифные инструменты, обеспечивающих целесообразную защиту внутреннего рынка от иностранных конкурентов, и создающих условия для эффективной интеграции национальной экономики в мировое хозяйство.

Большой энциклопедический словарь по экономике определяет систему как множество взаимодействующих элементов, находящихся в отношениях и связях друг с другом, составляющих целостное образование [2].Новая экономическая энциклопедия дает следующее определение: система - упорядоченная совокупность элементов, находящихся в отношениях и связях другу с другом и образующих определенную целостность, единство [9]. 
Состояние системы определяется совокупностью состояний всех ее элементов и связей, а оценивается системой в зависимости от целевого назначения надежностью и устойчивостью.Формирование систем тарифного регулирования внешней торговли в условиях интеграции осуществляется с учётом различных уровней унификации таможенных тарифов стран-участниц, объемов импорта конкретных товаров, чувствительности ставок ввозных таможенных пошлин для конкретной отрасли промышленности, а также международных обязательств стран-участниц [5].

Систему тарифного регулирования можно считать динамической системой. В связи с этим, целью исследования динамической системы в движении является достаточно точная идентификация существенных характеристик, а затем условий, необходимых для достижения устойчивого динамического равновесия.

Учитывая распространенную классификацию нетарифных методов регулирования (наличие таких элементов как стандартизация и квотирование), а в системе тарифного регулирования такого элемента как тарифное квотирование, можно утверждать, что в настоящее время (под воздействием глобализации, интеграции, МРТ) происходит диффузия двух методов регулирования (тарифного и нетарифного), т.е перевоплощение. Появляется новая технология формирования средств защиты внутреннего рынка от иностранной конкуренции, синтез ранее обозначенных методов.

\section{Список использованных источников:}

1. Бакаева, О.Ю., Галицкая, Н. В. Нетарифное регулирование внешней торговли в рамках ВТО // Вестник. - 2005. - №11. - С.169-174.

2. Большой энциклопедический словарь / Под.ред. А.Н.Азрилияна.7-е изд., доп.-М.: Институт новой экономики, 2008. - 1472c.

3. Винер. Я. Проблема таможенного союза / Я. Винер // Вехи экономической мысли. Т.6. Международная экономика / под.ред. А.П. Киреева. - М.: ТЕИС, 2006. - 950с.

4. Волгина, Н.А. Международная экономика / Н.А. Волгина. Москва: Эксмо, 2006. - 733с.

5. Гаращенко, Е.А. Анализ формирования системы тарифного регулирования внешней торговли ЕАЭС / Е.А. Гаращенко // Актуальные проблемы гуманитарных и социально-экономических наук: материалы XI Международ.научно-практической конференции. Вольск, март 2017г. №11: в 5т. - Вольск: ВВИМО, 2017. - Ч.5. - 256с. 
6. Давыденко, Е.Л. Внешнеторговая политика малой экономики в условиях либерализации международной торговой системы / Е.Л. Давыденко. - Минск: БГУ, 2008. - 278с.

7. Дадалко В.А. Мировая экономика: Учеб.пособие.Мн.:»Ураджай», «Интиерпресссервис», 2001. - 529с.

8. Кудров, В.М. Мировая экономика / В.М. Кудров. - 2-е изд., стереотипное. - Москва :Юстицинформ, 2010. - 509с.

9. Румянцева, Е.Е. Новая экономическая энциклопедия. 2-е изд..М.: ИНФРА-М, 2006. - 810c.

Дугінець Г.В., к. е. н., доцент Київський національний торговельно-економічний університет

\section{ГЛОБАЛЬНІ ІМПЕРАТИВИ РОЗВИТКУ МІЖНАРОДНИХ ВИРОБНИЧИХ МЕРЕЖ}

Незважаючи на всю суперечливість тенденцій глобалізації та регіоналізації, особливо в новому геополітичному контексті, незаперечним фактором розвитку сучасної світової економіки $\epsilon$ зростаюча взаємозалежність національних економік. Глобалізація відкриває нові можливості та загострює конкуренцію, змушуючи виробників шукати більш ефективні способи виробництва своєї продукції. У цьому прагненні компанії все частіше здійснюють фрагментацію бізнес-процесів по різним країнам відповідно до наявних переваг. В результаті відбувається формування міжнародних виробничих мереж, що змінюють структуру світової економіки в XXI столітті.

Взаємозалежність національних економік та їхнє взаємопроникнення; розширення масштабів товарообігу та інтенсифікація процесів руху товарів, капіталів, трудових ресурсів; створення інституцій міждержавного та міжнародного регулювання глобального виробництва; стандартизація міжнародних економічних процесів формують головні особливості розвитку міжнародних виробничих мереж на початку XXI ст.

Слід зазначити, що така трансформація світової економіки та взаємодій міжнародних суб'єктів багато в чому зумовлюється глобальними імперативами, ігнорування яких неминуче тягне за собою 
певні виклики: економічний спад, деградацію суспільства, а також неможливість скористатися перспективами Четвертої технологічної революції, в результаті якої в XXI ст. відбувається формування нової економіки передусім на основі наукомісткої промисловості.

У науковій літературі по-різному представлено поняття «імператив». Воно вживається в різних наукових дисциплінах та на практиці. Наприклад, визначено, що на розвиток національної економіки впливають такі імперативні чинники, як мобільність i транспарентність капіталу (у вигляді інвестицій та інновацій), належна конкурентоспроможність та детінізація економіки, висока правова дієвість чинних законів, широка громадська інформаційність, а також цивілізаційні стандарти і норми оплати праці [1]. В юриспруденції до імперативів належать нормативно-правові акти вищої юридичної сили (закони), а також підзаконні акти, постанови, накази, спрямовані на упорядкування й транспарентність найважливіших сегментів національної економіки [2, с. 8]. Деякі науковці визначають імператив залежно від мети їхнього дослідження, наприклад, розвиток суспільства, на думку Т. Дейнеки, підпорядковується імперативу постійного збагачення потенціалу його розвитку [3]. Інший приклад виокремлення інституційного імперативу, під яким розуміють обов'язкові норми та правила поведінки, сформовані інституційними структурами на базі традиційних «правил гри» 3 урахуванням морально-етичних принципів і максимальною імовірністю сприйняття середовища задля забезпечення ефективного регулювання та координації взаємовідносин індивідуумів, груп [4]. У більш вузькому розумінні прикладом інституціонального імперативу $є$ визначення У. Баффета, який називає його схильністю менеджерів компаній наслідувати поведінку інших менеджерів незалежно від того, на скільки ірраціональною може виявитися така поведінка («менеджери часто втрачають свою здатність мислити раціонально, коли в гру вступає інституціональний імператив») [5]. Це визначення має практичний, ілюструючий характер, проте однобічний.

Енциклопедичне розуміння цього поняття представлено у філософському словнику (лат. Imperatives - владний) і має такі значення:

1) наказ, настійна вимога, повинність [6];

2) підхід Е. Канта, який визначає його як правило, що містить об'єктивний примус до вчинку певного виду і виділяє: категоричний імператив - безумовне етичне розпорядження про належну поведінку людини як розумної істоти, що володіє вільною волею та гіпотетичний імператив - вимоги, яких слід дотримуватися як необхідних умов, аби 
досягти поставлених цілей [7].

У рамках цього дослідження глобальні імперативи розвитку міжнародних виробничих мереж розуміються як система формальних та неформальних вимог, правил, норм, що впливають на зміни в глобальному соціально-економічному середовищі, а також формують закономірності та тенденції розвитку цих мереж. Основні з них містять вимоги до економічних суб'єктів діяти так, аби у своїй діяльності сприяти цілісності глобальних та локальних територіальних систем; до обсягів і темпів споживання ресурсів, а також щодо регулювання економічного простору на основі поєднання ринкової самоорганізації, державного цілепокладання та міждержавного співробітництва.

3 урахуванням умов трансформації світової економіки наприкінці XX - на початку XXI ст. у цьому досліджені висунуто гіпотезу, що насамперед глобальними імперативами розвитку міжнародних виробничих мереж є фрагментація виробництва, транснаціоналізація, прискорення інноваційного розвитку, а також ущільнення виробничого ланцюга. При цьому на кожному новому витку розвитку світової економіки прояв окремого імперативу може трансформуватися: одні втрачатимуть свою актуальність, а інші іiі набуватимуть (наприклад, ущільнення виробничого ланцюга - це імператив, який проявився лише в першому десятилітті XXI ст.).

Підсумовуючи проведений аналіз теоретичного розуміння глобальних імперативів розвитку міжнародних виробничих мереж, визначимо ключові положення методологічного дискурсу щодо визначення їхньої сутності.

По-перше, НТП дозволив ефективно координувати та відстежувати всі стадії виробничого ланцюга, розташовані на великій відстані один від одного. Важливу роль відіграли також процеси лібералізації торгівлі та інвестицій, інституційні реформи в ключових транспортних i iнфраструктурних секторах, що підвищили ефективність всіх галузевих ланок виробничих мереж.

По-друге, крім технологічних та інституційних змін, слід зазначити роль структурних зрушень у світовому попиті наприкінці $\mathrm{XX}$ ст. Високі темпи зростання країн, що розвиваються, особливо в Азії, стимулювали стрімке зростання попиту та, відповідно, міжнародної торгівлі. Азія $є$ не тільки світовою фабрикою, але також генерує нових споживачів, що пред'являють попит на широке коло товарів і послуг. Це, в свою чергу, на практиці підтверджує тезу Майкла Портера, що «конкурентоспроможність країни створюється не на зовнішніх, а на внутрішніх ринках» [8, с. 218]. У результаті Китай починає займати вагоме місце у світовій економіці, а торгівля готовими 
виробами та послугами на початку XXI ст. зростає практично тими ж темпами, що і торгівля проміжною продукцією.

По-третє, рівень розвитку міжнародних виробничих мереж залежить від технічних характеристик виробленого товару, а також від витрат, що виникають у процесі фрагментації виробництва за різними стадіями та територіями, від зіставлення витрат виробництва 3 трансакційними витратами i витратами координації. Розміщуючи стадії виробництва в країнах з більш низькими витратами, компанії одночасно більше витрачають на послуги, необхідні для їхньої підтримки. Таким чином, існує певний оптимальний рівень фрагментації в рамках МВМ, що залежить від рівня розвитку торгівлі $\mathrm{i}$ трансакційних витрат. Аналіз світової практики показує, що розширення МВМ не може буди постійним процесом. Так, наприклад, після фінансової кризи в світі спостерігалося скорочення темпів їхнього розвитку внаслідок невизначеності поставок сировини i матеріалів. Інший приклад - після руйнівного цунамі в Японії в 2011 р. ряд компаній скоротили свої глобальні ланцюги вартості, особливо в автомобільній та електронній промисловості.

По-четверте, модель виробництва, що діє в останні роки, не обов'язково буде ефективною через 10-15 років. Діяльність багатьох МВМ базується на міжкраїнових відмінностях в трудових та капітальних витратах, які безперервно змінюються. Наприклад, у міру зростання добробуту Китай розвиває нові виробництва, що вимагають робочої сили 3 більш високою кваліфікацією, а деякі старі види виробництва переносяться в інші країни. Отже, існуючі міжнародні виробничі мережі будуть і далі трансформуватися, а тому ці зміни повинні бути ідентифіковані та враховані в економічній політиці ключових суб' єктів цих мереж, зокрема України.

\section{Список використаних джерел}

1. Ковальчук А., Криштоф А. Детінізація економіки як нормативноправовий імператив. Підприємництво, господарство і право, 2016. №. 1. С. 51-55.

2. Користін О.С. Відмивання коштів: теоретико-правові засади протидії та запобігання в Україні. К. : Поліграфкнига, 2007. 418 с.

3. Дейнека Т. А. Економічний імператив становлення глобального суспільства. Міжнародна економічна політика. 2017. №. 2 (27) С. 156-172.

4. Ковальчук М. В. Імперативи економічної безпеки держави: інституціональний підхід. Ефективна економіка, 2014, №. 11. URL: http://www.economy.nayka.com.ua/?op=1\&z=3574 
5. Баффет У. Институциональный императив: воспоминания биржевых трейдеров и бизнесменов. URL: http://1pixel.ru/view buf.php?id=54

6. Жюлиа Д. Философский словарь. [пер. с франц.]. М.: Междунар. отношения, 2000. 544 с.

7. Кант Е. Критика чистого раз ума. [пер. Н.Лосского, общ. ред. Ц.Арзаканян, М.Иткин] М. : Мысль, 1994. 591 с.

8. Портер М. Международная конкуренция, пер. с англ. М. : Международные отношения, 1993. 896 с.

Дуцька А. С., к. е. н., АТ СК «АХА Страхування»

\section{МІЖНАРОДНІ СТАНДАРТИ ФІНАНСОВОЇ ЗВІТНОСТІ У КОНТЕКСТІ ПОСИЛЕННЯ КОНКУРЕНТНИХ ПЕРЕВАГ СУБ'ЄКТІВ ГОСПОДАРЮВАННЯ}

Застосування суб'єктами господарювання міжнародних стандартів фінансової звітності (далі - МСФЗ) відіграє важливу роль на шляху європейської інтеграції нашої держави. Адже фінансова звітність, що складена на основі міжнародних стандартів, забезпечує учасників ринкового простору об'єктивною, прозорою, релевантною та співставною інформацією щодо особливостей їх діяльності, тим самим посилюючи конкурентні переваги національних підприємств у тому числі й на ринках країн Свропейського Союзу.

Використання МСФЗ у фінансово-господарській діяльності суб'єктів господарювання сприяє підвищенню довіри користувачів фінансової звітності до діяльності підприємств та переводить розвиток конкурентних відносин учасників ринкового простору на новий рівень. За таких обставин для посилення конкурентних переваг суб'єктів господарювання особливого значення набуває інтелектуальний капітал, ефективне використання якого у процесі організації застосування на підприємствах МСФЗ, дозволяє набути виняткових переваг, які не піддаються копіюванню іншими учасниками. У цьому відношенні Н. Кравченко доречно зауважує щодо ролі компетенцій i здатностей працівників у побудові бізнес-простору підприємств задля «набуття, розвитку і поширення власних конкурентних переваг» $[1, \mathrm{c}$. 46]. 
Зазначене вище підтверджує i той факт, що національним законодавством запроваджено законодавче підгрунтя для поширення застосування МСФЗ шляхом передбачення обов'язковості використання МСФЗ окремими категоріями підприємств. Так, зокрема у п. 2 ст. 12 Закону України «Про бухгалтерський облік та фінансову звітність» зазначено: «підприємства, що становлять суспільний інтерес, публічні акціонерні товариства, суб'єкти господарювання, які здійснюють діяльність у видобувних галузях, а також підприємства, які провадять господарську діяльність за видами, перелік яких визначається Кабінетом Міністрів України, складають фінансову звітність та консолідовану фінансову звітність за міжнародними стандартами» [2]. Для інших суб'єктів господарювання законодавством України передбачена можливість застосування міжнародних стандартів за власною ініціативою. Подібна практика застосовується і у 144 юрисдикціях світу, де передбачена обов'язковість застосування МСФЗ для всіх або більшості національних суб'єктів господарювання (рис. 1).

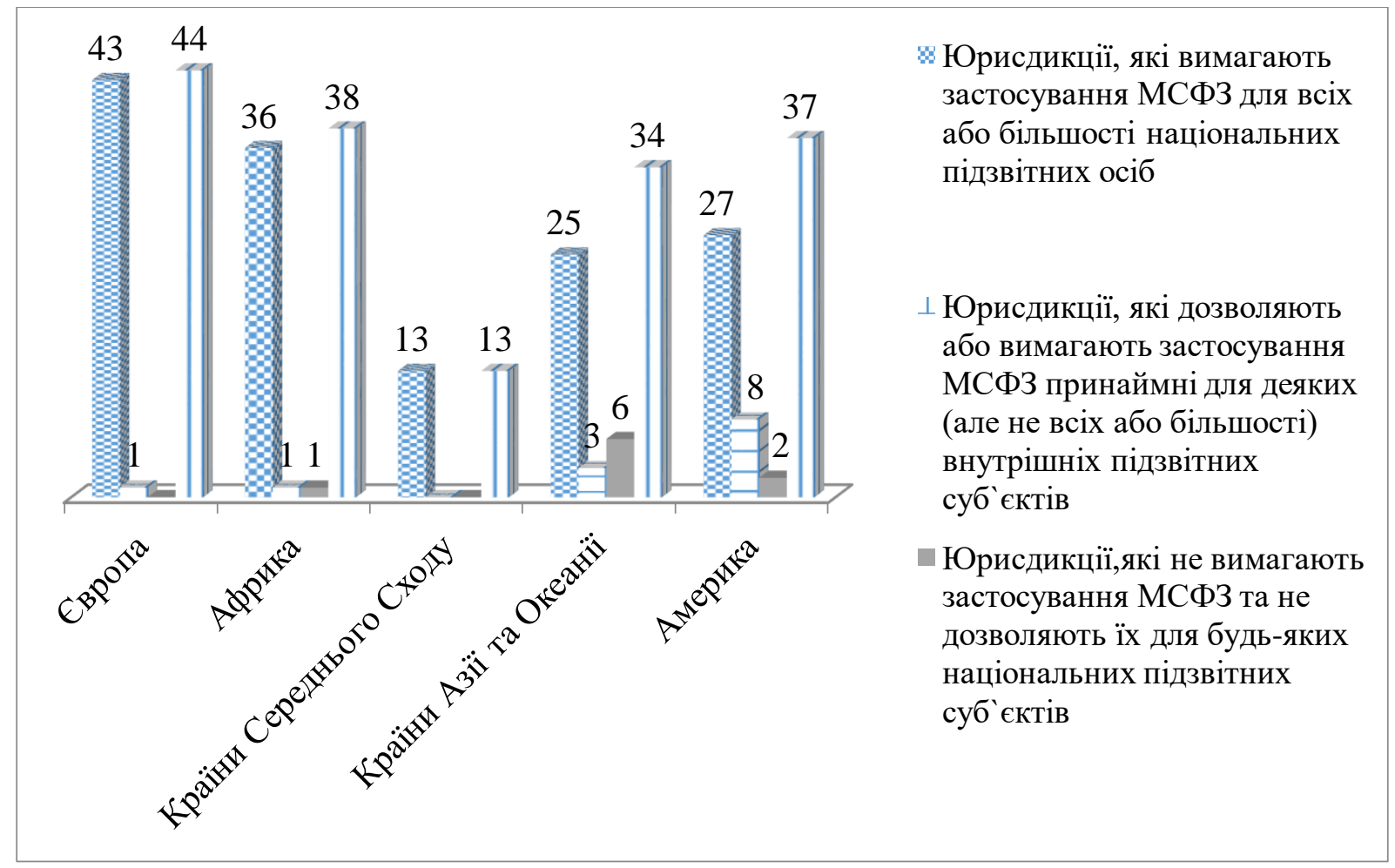

Рис.1. Застосування МСФЗ у 166 юрисдикціях регіонів світу (станом на 25.04.2018), (складено автором на основі [3])

У той же час перед підприємствами у процесі практичного застосування МСФЗ постають виклики, пов'язані з їх адаптацією до 
особливостей розвитку економіки України. У якості прикладу можна навести МСФЗ 16 «Оренда», що набрав чинності з 01 січня 2019 року та передбачає відображення в обліку орендаря операцій оренди на підставі проведених розрахунків відповідно до інформації, що міститься в договорі оренди. При цьому суми витрат, що орендар визнаватиме в обліку відповідно до здійснених розрахунків, відрізнятимуться від зазначених сум в акті виконаних робіт, котрий відповідно до чинного законодавства має статус первинного документу для відображення витрат. Зважаючи на пріоритетність на законодавчому рівні для окремих категорій підприємств вимог МСФЗ у порівнянні 3 вимогами національного законодавства, виникає запитання: яким документом на національному рівні слід підтвердити відображені в обліку на основі розрахунків витрати? Чи достатньо буде для цього оформленого наказу керівника, який міститиме всі реквізити первинного документу? Зважаючи, що МСФЗ здебільшого описують загальні принципи складання звітності та передбачають певну варіативність вибору на основі професійного судження, для суб'єктів господарювання посилюється значення їх облікової політики. У вказаному документі важливо зафіксувати основні моменти щодо прийнятих суб'єктами господарювання рішень з організації обліку, що не суперечать МСФЗ та чинному законодавству України та яким чином підприємство затверджуватиме відображення в обліку витрат по орендним угодам у випадку з МСФЗ 16 «Оренда».

На думку науковців однією з причин, що зумовлюють подібну ситуацію $є$ відсутність вітчизняних представників бухгалтерського обліку та аудиту у складі органів, що встановлюють стандарти [4]. Підтримуючи вищезазначену позицію, варто додати необхідність посилення якості регуляторної підтримки учасників ринкового простору у національній економіці. Наразі Міністерство фінансів України оприлюднює на офіційній веб-сторінці переклад на українську мову чинних міжнародних стандартів фінансової звітності та обліку, а також Тлумачень (КТМФЗ та ПКТ), проте на веб-сторінці відсутні роз'яснення національного регулятора щодо особливостей їх адаптації до умов національної економіки. У цьому контексті, зважаючи, що Меморандумом про взаємодію, співробітництво та координацію дій щодо запровадження в Україні Міжнародних стандартів фінансової звітності на Міністерство фінансів України покладено функції основного координатора [5], задля уникнення розбіжностей, центральному органу виконавчої влади у сфері бухгалтерського обліку спільно з представниками наукових та ділових кіл доречно розробити 
офіційні рекомендації щодо особливостей практичного застосування МСФЗ в умовах національної економіки.

Таким чином організація застосування МСФЗ у господарській діяльності учасників ринкового простору $є$ важливим стратегічним кроком, що сприятиме зацікавленості іноземних інвесторів діяльністю суб'єктів господарювання на національному рівні та посилить конкурентні переваги вітчизняних підприємств на міжнародних ринках. На шляху подолання викликів, пов'язаних із застосуванням підприємствами МСФЗ у національній економіці, важливим $\epsilon$ забезпечення дієвого механізму регулювання та пристосування вимог МСФЗ до економіки України шляхом взаємодії науковців, керівників суб'єктів господарювання, фахівців у сфері МСФЗ, бухгалтерського обліку та аудиту, а також органів державної влади для досягнення синергетичного ефекту.

\section{Список використаних джерел}

1. Кравченко Н.В. Глобальні детермінанти трансформації конкурентних відносин // Науковий вісник Ужгородського національного університету. Серія: Міжнародні економічні відносини та світове господарство: науковий журнал, 2018. - випуск 19, частина 2. - C. 42-47.

2. Закон України «Про бухгалтерський облік та фінансову звітність» № 996-ХІVвід 16.07.1999 [Електронний ресурс]. - Режим доступу: https://zakon.rada.gov.ua/laws/show/996-14.

3. Аналіз профілей юрисдикцій МСФ3 [Електронний ресурс]. Режим доступу: https://www.ifrs.org/use-around-the-world/use-of-ifrsstandards-by-jurisdiction/\#analysis.

4. Мельничук Б.В. Проблеми запровадження МСФЗ в Україні: інституціональний підхід [Електронний ресурс]. - Режим доступу: http://magazine.faaf.org.ua/problemi-zaprovadzhennya-msfz-v-ukrainiinstitucionalniy-pidhid.html.

5. Меморандум про взаємодію, співробітництво та координацію дій щодо запровадження в Україні Міжнародних стандартів фінансової звітності Міністерства фінансів України та Національного банку України від 10.06.2011 [Електронний ресурс]. - Режим доступу: https://zakon.rada.gov.ua/laws/show/n0016201-11. 
Дучинська H.I., д.е.н., професор, Дніпровський національний університет імені Олеся Гончара

\section{ДОВІРА ЯК ІНСТИТУЦІЙНИЙ ЧИННИК СОЦІАЛЬНО- ЕКОНОМІЧНОГО РОЗВИТКУ}

Соціально-економічний розвиток країни передбачає наявність довіри між іiі економічними, політичними, соціальними та іншими суб'єктами.

Економічна довіра являє собою впевненість людей у позитивних наслідках економічних зрушень, трансформацій, перебігу процесів у грошово-кредитній, інвестиційній, податковій сферах діяльності.

У нашій країні склалося так, що рівень довіри до іноземних валют вищий, ніж до власної [1, с. 100], що проявляється у зростанні попиту населення до іноземної валюти на внутрішньому ринку. Недовіра до фінансових інститутів, i, перш за все, до банків, негативно відображається на обсягах заощаджень домашніх господарств і фірм.

Недовіра у трудових колективах між менеджерами і робітниками спонукає до прихованого страйкування, зниження стимулів до праці, відсутності ефективної самовіддачі, що негативно впливає на якість виготовленої продукції чи наданих робіт, веде до зниження конкурентоспроможності підприємства тощо.

Недовіра інвесторів щодо інвестування в активи 3 метою примноження їх вартості шляхом отримання певного рівня доходу викликає зниження ділової активності в економіці, в цілому.

Товари і послуги не принесуть користі споживачам і доходів фірмам, якщо втратять у них довіру.

Соціальна довіра - це впевненість у надійності соціального об'єкта, що базується на взаємовідносинах 3 ним, 3 можливістю впливати на нього, або ж контролювати цей об'єкт чи заходи, що ним пропонуються. Соціальна недовіра, що породжується низькими пенсіями, їх значною диференціацією, низькими виплатами по безробіттю, утриманню престарілих категорій населення породжує соціальну нестабільність, збирає майдани.

Особливого значення набуває довіра до державних органів влади, Президента, суду, поліції, церкви, армії, що впливає на соціальну і політичну стабільність у суспільстві, наявність впевненості у подальшому соціально-економічному розвитку. Така довіра, 
безумовно, відображається на функціонування інститутів держави і $є$ об'єктивною основою ефективності політики, що здійснюється ними.

Відсутність довіри, як i ii втрата $\epsilon$ основою виникнення непередбачених наслідків, що впливають на діяльність державних та суспільних інститутів, ігнорують їх рішення чи гальмують реалізацію останніх. Відсутністю довіри населення характеризуються президентські вибори в Україні, коли більшість населення проголосували проти діючого Президента, не маючи уявлення про програму дій нового.

Україна посіла перше місце у світі за рівнем недовіри до влади вже третій рік підряд. Так, владі довіряють лише 9\% населення, тоді як, у середньому, довіра у пострадянських країнах коливається в межах $46 \%$, загалом у світі довіряють владі 56\% населення. Зазначену інформацію оприлюднила аналітично-консультативна компанія Gallup [2].

Цікаво, що відразу після обрання президентом П.О. Порошенка у 2014 році довіру до влади в цілому відчували 24\% українців. Проте багато українців побачили, що влада не в змозі виконати вимоги Майдану. 32015 року довіра населення до влади не перевищувала 14\% [2].

У серпні-жовтні 2018 року Програма USAID «Нове правосуддя» здійснила опитування населення України та правників, які $\epsilon$ учасниками судових проваджень, але не $\epsilon$ працівниками органів судової системи.

В опитуванні населення взяли участь майже 2,5 тис. респондентів. У всеукраїнському опитуванні правників, що $\epsilon$ учасниками судових проваджень, взяли участь 400 респондентів, серед яких адвокати, прокурори, юристи, що виконують функції адвокатів для державних органів влади та підприємств, слідчі Міністерства внутрішніх справ.

У результаті опитування отримані такі дані стосовно довіри. Рівень довіри суспільства до судової влади демонструє помітне зростання в останні роки. Так, $16 \%$ респондентів загальнонаціонального опитування населення визнали, що довіряють повністю чи скоріше довіряють судовій владі, це втричі більше у порівнянні $з$ критично низькими 5\% в 2015 році. $21 \%$ респондентів висловили позицію нейтрального сприйняття судової влади, вибираючи варіант відповіді «і довіряю, і не довіряю», а 59\% респондентів визнали, що скоріше не довіряють, чи зовсім не довіряють судовій владі [3]. 
Вперше в опитуванні була додатково застосована шкала системи «Свробарометр», де відсутня можливість респонденту відзначити нейтральне сприйняття. Відповідно до цієї шкали, 20\% респондентів схильні довіряти судам, а 71\% - схильні не довіряти [3].

Рівень довіри правників до судової влади виріс з 38\% в 2017 році до 41\% в 2018 році. 47\% правників виявили довіру окремим судам, де вони здійснюють представництво сторін [3].

У лютому 2019 року соціологічною службою Центру Разумкова в усіх регіонах України за винятком Криму та окупованих територій Донецької та Луганської областей проведене загальнонаціональне дослідження довіри населення до суспільних інститутів.

Найчастіше громадяни України висловлюють довіру волонтерським організаціям (їм довіряють 67\% опитаних), Збройним Силам України (62\%), Державній службі з надзвичайних ситуацій (61\%), церкві (61\%), добровольчим батальйонам (57\%). До інституцій, яким довіра висловлюється частіше, ніж недовіра, відносяться також Державна прикордонна служба (ій довіряють 52\% опитаних, не довіряють - 36\%), Національна гвардія України (відповідно 50\% і 38\%), 3МІ України (відповідно 49\% і 43\%) та громадські організації (відповідно 45\% і 41\%).

Недовіра найчастіше висловлюється державному апарату (чиновникам) (83\% їм не довіряють), ЗМІ Росії (83\%), Верховній Раді України (82\%), судовій системі (78\%), політичним партіям (77\%), Уряду України (75\%), комерційним банкам (75\%), Президенту України (71\%), Прокуратурі (70\%), Національному банку України (68\%), Верховному Суду (65\%), Спеціалізованій антикорупційній прокуратурі (65\%), Національному антикорупційному бюро України (НАБУ) (64\%), Національному агентству з питань запобігання корупції (НАЗК) (64\%), Антикорупційному суду (62\%), Конституційному Суду (62\%), профспілкам (58\%)[4].

Довіра населення до суспільних інститутів має вагове значення, так як сприяє прискоренню реалізації прийнятих ними рішень, а також $\epsilon$ свідченням впевненості населення у надійності зазначених інститутів. Втрачену надію повернути досить складно. Для цього потрібен час і послідовність цілеспрямованих дій по її відновленню, тому завоювати довіру в сучасному суспільстві є складним завданням для суспільних інститутів, так як для іiі вирішення потрібна також модернізація інституціонального середовища.

Як інституційний чинник соціально-економічного розвитку довіра потребує вивчення науковцями і представника державних інститутів. Зростанню рівня довіри сприятимуть економічні i 
соціальні, політичні заходи, які мають бути використані державними інститутами. Серед них такі:

- встановлена законодавством відповідальність депутатів, Президента, партій за передвиборчі програми, поставлені цілі і завдання;

- прозорість в діяльності органів влади і їх звітність перед державою і населенням;

- боротьба 3 корупцією в усіх сферах діяльності, створення громадських організацій контролю за результатами антикорупційної боротьби;

- поєднання високих винагород чиновникам 3 контролем i суворою відповідальністю за результати діяльності;

- зменшення диференціації доходів населення, формування середнього класу, створення робочих місць, підвищення заробітної плати у відповідності 3 потребами розвитку робітника і необхідності розширеного відтворення;

- відповідна реакція на проблеми, що виникають у населення 3 боку соціальних інститутів, чиновників тощо.

\section{Список використаних джерел}

1. Кузьмін О.С., Бонецький О.О. Довіра як економічна категорія/О.Є Кузьмін, О.О.Бонецький // Науковий вісник НЛТУ України. - 2010. Вип 20.2. - С.100-104.

2.Рівень довіри до влади в Україні найнижчий у світі [Електронний pecypc]. - Режим доступу: https://24tv.ua/ukrayina_tag1119

3.Рівень довіри суспільства до судової влади в процесі реформ//

[Електронний ресурс]. - Режим доступу: rsu.gov.ua

4.Рівень довіри до суспільних інститутів та електоральні орієнтації громадян України // [Електронний ресурс]. - Режим доступу: razumkov.org.ua/.../riven-doviry-do-suspilnykh-instytutiv-ta 
Смельяненко Л. М., д.е.н., професор

Москвіна В.І., аспірант

ДВНЗ “Київський національний економічний

університет імені Вадима Гетьмана"

\section{ТРАНСФЕРТИ В РЕГУЛЮВАННІ БЮДЖЕТНИХ ВІДНОСИН СОЦІАЛЬНОЇ СФЕРИ}

Одним із найважливіших кроків у напрямку макроекономічної стабілізації повинен стати перегляд існуючих в Україні підходів до виконання державою іiі перерозподільної функції. Соціальна сфера формується за умов, коли ринковий механізм господарювання не в змозі самостійно врегулювати перерозподіл суспільних благ. Дієва державна соціальна політика набуває актуальності в період економічних криз та $\epsilon$ необхідною для пом'якшення дисфункції внутрішнього ринку. Варто відзначити, що щорічно із державного бюджету України майже 70\% соціальних видатків перерозподіляється на програми із покращення рівня життя нуждених верств населення. Проте, попри намагання представників влади, рівень бідності щорічно зростає, а негативним наслідком цього постає проблема масового відпливу робочої сили закордон. Сучасна ситуація в сфері соціального забезпечення та рівень ї фінансування є незадовільними, оскільки не сприяє загального покращенню рівня та якості життя населення, а тому вимагає врегулювання із внесенням грунтовних змін у соціальне бюджетування.

У вітчизняних наукових та професійних колах дефініцію трансферту традиційно використовують в соціально-економічному середовищі при формуванні та реалізації суспільних відносин на мікро- та макрорівнях. За класичним тлумаченням Бізнес-словника трансфер трактується як “Переміщення коштів між двома або більше рахунками, що підпорядковані одному або різним суб'єктам” [3]. А 3 точки зору важливості для державних фінансів, на чому слушно зауважує С. Грімслі, “трансфертні платежі - це виплата грошей або допомоги в натуральній формі (наприклад, талони на харчування), які уряд надає особам, не отримуючи ніяких товарів або послуг в обмін. Трансферні платежі не враховуються при розрахунку валового внутрішнього продукту (ВВП), оскільки вони не є компенсацією, отриманою в обмін на товари або послуги. Натомість трансфертні платежі розглядаються як перерозподіл доходу, оскільки уряд використовує дохід, який він отримує від оподаткування доходів для 
здійснення трансфертних платежів" [1]. А отже, трансфер в економічному сенсі, набуває формату переміщення грошових коштів від державних органів до соціально вразливих верств населення на безоплатній основі.

На мікрорівні загальновживаним вважається поняття трансферту у ціноутворенні. Так, за визначенням В. Чаусова та А. Ашкінадзе [6], трансфертне бюджетування використовується в умовах повного або часткового госпрозрахунку на підприємстві. Купівля та продаж ресурсів між АГО за внутрішніми цінами призводить до спотворення картини доходів і витрат по АГО при їх прямому обліку. Трансферт частини витрат або доходів зі статей одного АГО на статті іншого відповідно до правил внутрішнього ціноутворення необхідний для адекватної оцінки діяльності АГО. Для дієвості трансфертів повинні підтримуватися певні механізми налаштування розрахунків:

- використання шаблонів при рознесенні значень статей найпростіший для користувачів спосіб, однак відрізняється максимальною жорсткістю і не завжди задовольняє вимогам методик бюджетування;

- використання нормативів i додаткових довідників при рознесенні значень статей (наприклад, витрат на оренду відповідно до займаних АГО площами); є розширенням механізму шаблонів, що дозволяє при описі алгоритмів оперувати масовими даними;

- використання мови формул - як правило, дозволяє реалізувати практично всі вимоги методик бюджетування, однак неакуратно їх реалізація в системі може викликати довгостроковий обчислень;

- мова сценаріїв - самий гнучкий і найбільш ефективний 3 точки зору виконання інструмент для опису алгоритмів трансфертів, однак вимагає знання програмування.

Подібно до моделі використання трансфертів на мікрорівні економіки, також існує й інший вид застосування трансфертного регулювання на вітчизняному поприщі наукових досягнень, щоправда на макроекономічному рівні. Так, відповідно до науково-професійних поглядів О. Жихора та О. Кириленко [5], феномен бюджетних трансфертів вперше було окреслено в рамках введення оновленого Бюджетного Кодексу України у 1996 році, що містив оновлену бюджетну класифікацію трансфертів. Згідно оновленої класифікації трансферти було поділено на дві групи залежно від цільового спрямування коштів - поточні та капітальні. Відповідно, до числа поточних офіційних трансфертів відносили грошові допомоги 
(дотації), які одержували бюджети нижчих рівнів управління при наявності недостатнього обсягу фінансових коштів. На відміну від поточних трансфертів, капітальні трансферти (субвенціï) передбачали цільове використання одержаних коштів. Цілі, на які спрямовувалися субвенції, здебільшого були пов'язані з виконанням органами місцевого самоврядування делегованих державою повноважень. Тобто, можна сказати, що фактично грошовими коштами фінансувалась діяльність місцевих органів управління.

У Канаді ефективною вважається специфічна в порівнянні із Україною форма міжбюджетного трансферту, оскільки перерозподіл відбувається на рівні муніципалітетів. Так, схема перерозподілу містить два муніципальні органи влади, що фінансуються за рахунок власних коштів. Фактично, якщо на програму одного муніципалітету не вистачає фінансових коштів, представник владної структури звертається до іншого муніципалітету за додатковим фінансуванням. Економічна специфіка трансферту на муніципальному рівні залишається. А отже, для розглянутого прикладу характерним $є$ також й регулювання трансфертів на мезорівні. Цікавим, на наш погляд, слід визнати досвід макрорівеневого трансферту в Канаді, де представники муніципалітетів звертаються за додатковим фінансуванням до представників загальнодержавних органів влади й отримують трансферт, якщо рівень ефективності та корисності визначеної програми відповідає сумі трансферта [4]. Така система бюджетування функціонує й у соціальній сфері.

Згідно досвіду трансформації системи соціального забезпечення Південної Африки, програми соціальної допомоги фінансуються із місцевого бюджету виключно за рахунок отриманих доходів. При умові недостатності фінансових коштів, загальнодержавні органи управління фінансують соціальні програми за рахунок трансфертів із загального бюджету країни. Така модель соціального бюджетування є діючою 3 2000-х років, гарантує та забезпечує успіхи у подоланні рівня бідності [2].

На нашу думку, феномен бюджетних трансфертів доцільно трактувати як перерозподіл грошових коштів на здійснення цільових програм соціально-економічного розвитку, що попередньо $\epsilon$ узгодженими з усіма підрозділами органів місцевого управління, чітко визначені та відповідають фактичним потребам населення. Таке визначення вміщує в себе принципи міжбюджетних трансфертів, що наразі функціонують в Україні, а також принцип цілепокладання, що включає в себе фінансування на чітко визначені цілі розвитку, тобто регіональні програми, як це позитивно врегульовано у Канаді. 
Отже, моделі трансфертного бюджетування соціальної сфери як окремого економічного базису наразі в Україні не існує, проте базис для використання трансфертного фінансування державних та місцевих видатків закладений майже у кожний рівень формування бюджету в тому чи іншому вигляді. Із світового досвіду, на нашу думку, корисними для української практики будуть ідеї адресного надання трансфертів, а також використання міжмісцевих трансфертів, прикладом якого слугує досвід Канади.

\section{Список використаних джерел}

1. Grimsley S. Transfer Payment: Definition \& Examples [Електронний pecypc] / Shawn Grimsley // Study.com - Режим доступу до pecypcy: https://study.com/academy/lesson/transfer-paymentdefinition-examples-quiz.html.

2. Sepulveda M. The Human Rights Approach to Social Protection / Magdalena Sepulveda, Carly Nyst, // Ministry for Foreign Affairs of Finland. - 2012. - $65 \mathrm{p}$.

3. What is franfer? Definition and meaning [Електронний ресурс] // Business Dictionary. - 2019. - Режим доступу до ресурсу: http://www.businessdictionary.com/definition/transfer.html.

4. Богачова О. В. «Горизонтальні» міжбюджетні трансферти: досвід зарубіжних країн і можливість застосування в Росії / О. В. Богачова, О. О. Феоктистова. // Фінансова аналітика: проблеми та рішення. - 2015. - №24. - С. 55-68.

5. Жихор О. Б. Бюджетні трансферти та їх види / О. Б. Жихор, О. П. Кириленко // Місцеві фінанси / О. Б. Жихор, О. П. Кириленко. Київ: УБС НБУ, 2015. - С. 232.

6. Чаусов В. Як обрати систему бюджетування? [Електронний ресурс] / В. Чаусов, А. Ашкінадзе // Управлінський облік і бюджетування. - 2019. - Режим доступу до ресурсу: http://budtech.ru/select_budgeting.html. 
д.е.н., старший науковий співробітник, Національний інститут стратегічних досліджень

\section{УКРАЇНА 2020-2024: ОБГРУНТУВАННЯ СТРАТЕГІЧНИХ IМПЕРАТИВІВ}

Завдання наукового обгрунтування процесу формування економічної стратегії держави, актуалізується щоразу на початку нового політичного циклу, який об'єктивно характеризується зростанням трендів популізму. На сучасному етапі, 3 різким зростанням медійних впливів та застосуванням спеціальних мережевих технологій штучного формування суспільної думки важливість такого обгрунтування суттєво зростає.

Наукові підходи до стратегування суспільного розвитку дозволяють встановити об'єктивні обмеження, в рамках яких має реалізуватися стратегії, а також ранжувати пріоритетність цілей, на досягнення яких вони спрямовані. Застосування нами таких підходів дозволило сформувати системний результат у вигляді низки сформульованих стратегічних імперативів - обов'язкових рамкових цілей стратегій, які продиктовані станом суб'єкта і об'єкта їх реалізації.

Імператив перший. Динамізація економічного зростання. Прискорення темпів економічного зростання необхідне для відновлення у прийнятні терміни докризових рівня та якості життя населення України, зменшення диспаритету у рівні життя з населенням країн СС, що важливо в контексті євроінтеграційних інтенцій, формування достатнього ресурсу для виконання основних функцій держави (оборони та національної безпеки, соціального захисту, екологічної безпеки тощо) та участі у глобальних процесах інноваційно-цифрових та технологічних трансформацій, підтримання платоспроможності по державному боргу країни.

Для прискорення економічного зростання важливо подолати чинники, що марнують (поглинають) потенціал зростання (це насамперед структурні диспропорції, неадекватні економічні механізми та нефективне державне управління) та розвинути чинники, що прискорюють зростання (всебічна підтримка підприємництва, сприятливі умови для інвесторів, повноцінна реалізація потенціалу відкритості економіки, орієнтація фінансового сектору на ресурсне забезпечення структурних змін). 
Імператив другий. Інклюзивність економічного розвитку задіяність у формуванні та отриманні результату усіх членів спільноти та відчуття відповідальності за цей результат. На цій основі інклюзивності стає можливим досягнення якості економічного зростання, яка дозволить досягти легітимності політики держави та реформ, що проводяться, знизити рівень соціальної напруженості, розвивати необхідні для розбудови соціального капіталу інклюзивні інститути, здійснити деолігархізацію та детінізацію суспільноекономічної моделі розвитку.

Забезпечення більшої залученості потребує модернізації секторальної та інституційної структури економіки на основі визначення пріоритетів стратегії з позицій максимального залучення спільноти до реалізації завдань стратегії та отримання позитивного результату їх реалізації. Основними засобами побудови інклюзивності $\epsilon$ реорганізація ринку праці (локалізація та узгодження демографічних, кваліфікаційних та секторальних характеристик), розвиток підприємництва, активізація місцевого розвитку, підвищення ефективності соціальних програм, впровадження соціальної відповідальності, формування партисипативних інститутів.

Імператив третій. Ендогенність - сприяння максимальній реалізації національного економічного потенціалу на основі оптимізації інституційної організації національної економіки, досягнення переважання ендогенних чинників економічного зростання як таких, що формуються внаслідок внутрішніх для економічної системи процесів, а відтак - можуть бути об'єктом стимулювання засобами державної політики. Для цього потрібно подолати тренди екзогенізації, що нав'язують структуру економіки, якій властиві структурна ригідність та неінклюзивність, підвищені ризики волатильності. Слід враховувати, що наразі екзогенна модель вже набула властивостей інституційної пастки.

Досягнення ендогенності має відбуватися через створення інституційних умов для здійснення економічним суб'єктом раціонального вибору на користь пріоритетного задіяння складових національного економічного потенціалу. Цей вибір має вигравати в інституційній конкуренції різних моделей підприємницької поведінки. Тому ендогенність недосяжна засобами протекціонізму, а може формуватися на основі відповідних структурних змін національної економіки, які вестимуть до підвищення факторної продуктивності ендогенних ресурсів [ 1 ]. Складовими політики сприяння ендогенізації $\epsilon$ інвестиційна та інноваційна політика, розвиток людського капіталу, поширення комунікацій і формування мережевої взаємодії 
економічних суб'єктів, яка має стати основою локалізації створення доданої вартості в рамках національної інституційної системи.

Імператив четвертий. Локалізація - залучення до економічного обороту не задіяних досі ресурсів, які доступні на регіональному рівні, посилення їх капіталізації, - що містить потужний потенціал для значного прискорення економічного зростання на основі його ендогенізації. Зміцнення спроможності регіональних спільнот ефективно вирішувати значну частину проблем територіального розвитку посилює інклюзивність моделі економічного розвитку [ 2 ].

Локалізація відбувається шляхом проведення відповідної регіональної політики та продовження реформи децентралізації 3 утвердженням фінансової та управлінської спроможності ОТГ щодо виявлення та розкриття потенціалів розвитку територій, залучення локального бізнесу до вирішення проблем територіального розвитку. Локалізація має спиратися на побудову на регіональному рівні економіко-правового середовища, «дружнього до розвитку» - тобто такого, що активно заохочує підприємницьку діяльність, генерує мережеві зв'язки, сприяє припливу до регіону інвестицій, реалізації людського капіталу регіону. Цьому сприятиме формування відповідних інститутів місцевого розвитку та вертикальної комунікації.

Імператив п’ятий. Інституціалізація. Неусталеність інституційного середовища створює суттєві перешкоди для формування раціональних дій на мікро- та макрорівнях та перешкоджає узгодженню цих дій, тим більше - їх підпорядкуванню цілям політики держави. Важливо вибудувати інституційні механізми, які дозволять оптимізувати реалізацію вищенаведених імперативів, досягти дієвості політики держави за рахунок іï «озброєння» сучасним інституційним інструментарієм.

Інституціалізація дозволяе оптимізувати використання ресурсного потенціалу завдяки уточненню функціональних ролей учасників відтворювального процесу, досягти синергічності взаємодії економічних суб'єктів завдяки іiі передбачуваності та сталості на основі визначених норм поведінки, зміцнити стратегічність розвитку та підвищити факторну продуктивність шляхом подовження горизонту взаємодії через підвищення довіри в суспільстві [ 3 ].

3 нашої точки зору, підпорядкування стратегування соціальноекономічного розвитку зазначеним імперативам дасть змогу уникнути ризиків популізму з наступною втратою дієвості політики держави, дозволить зберегти та посилити суб' єктність соціально-економічного розвитку України. 


\section{Список використаних джерел}

1. Romer, D. Endogenous Growth. Advanced Macroeconomics (Fourth ed.). - New York: McGraw-Hill, 2011.

2. OECD Regional Outlook 2016: Productive Regions for Inclusive Societies. Paris: OECD Publishing, 2016.

3. Putnam R.D. Bowling Alone: The Collapse and Revival of American Community / Robert D. Putnam. - N.-Y: Simon and Schuster.- 2000.

Катран М.В.,к.е.н., ДП «Укрметртестстандарт»

\section{ПРОБЛЕМИ ЗМІСТУ І МЕТОДИКИ ВИЗНАЧЕННЯ ОБСЯГУ ВНУТРІШНЬОГО РИНКУ}

Питання розвитку внутрішнього ринку споживчих товарів тривалий час перебувають в центрі уваги дослідників різних шкіл та напрямів економічної думки. Проблеми формування i розвитку внутрішнього ринку та його регулювання досліджено у працях таких українських вчених-економістів, як: В. Геєця [4], В. Лагутіна [1;2], А. Мазаракі [2], О. Пустовойта [5;6], В. Точиліна [7], Ю. Уманціва [8] та ін. Між тим, методологія визначення обсягу внутрішнього ринку залишається дискусійною, недостатньо розкритою та обгрунтованою.

Мета: аналіз та визначення сучасних методологічних підходів у дослідженні обсягу внутрішнього ринку.

Матеріали і методи. Застосовано сукупність наукових методів i підходів, зокрема: системний та структурний, факторний та порівняльний, синтезу й аналізу.

Обсяг ринку впливає на продуктивність, так як великі ринки дозволяють компаніям скористатися ефектом економії в масштабі. Традиційно доступні компаніям ринки обмежувалися кордонами їх країни. В епоху глобалізації міжнародні ринки частково можуть замінити внутрішні, особливо це стосується невеликих держав. Існує багато емпіричних досліджень, які доводять позитивний взаємозв'язок між відкритістю торгівлі i зростанням економіки. I хоча деякі дослідження ставлять під сумнів міцність такого зв'язку, вироблена загальна позиція щодо позитивного впливу торгівлі на економічне зростання, особливо в країнах з невеликими внутрішніми ринками. На 
прикладі Європейського Союзу видно значимість розміру ринку для конкурентоспроможності, оскільки завдяки більш тісної інтеграції збільшилася загальна ефективність. Незважаючи на те, що спрощення торгових бар'єрів і приведення стандартів у відповідність з вимогами Європейського Союзу здійснили вплив на зростання обсягу експорту в регіоні, ще залишається безліч бар'єрів для створення по-справжньому єдиного ринку.

Для розрахунку кількісної величини внутрішнього ринку економісти використовують «розмір внутрішнього ринку», який характеризує сукупну ринкову вартість товарів і послуг, що було придбані для кінцевого споживання резидентами країни на внутрішніх товарних ринках за певний період.

На даний час в економічній науці не існує єдиної загальноприйнятої методики розрахунку величини внутрішнього ринку. Так, фахівці Всесвітнього Економічного форуму використовують формулу [10]:

$$
V R=\log \text { ВВП}(П К С)+\mathrm{I}(П К С)-\mathrm{E}(П К С)(1)
$$

Розмір внутрішнього ринку підраховується як натуральний логарифм від суми валового внутрішнього продукту за паритетом купівельної спроможності (ПКС) плюс загальна сума імпорту товарів $і$ послуг (ПКС), за вирахуванням загальної суми експорту товарів i послуг (ПКС). Дані потім нормалізуються до значень від 1 до 7. При визначенні розміру ринку для підприємств країни експорт може трактуватися як заміщення внутрішнього попиту.

Ця методика вже довгий час використовується у розрахунку Глобального індексу конкурентоспроможності. Так, Україна в 20162017 рр. за показником «розмір внутрішнього ринку» посідала 45 місце серед 139 країн, а в 2008-2009 рр. посідала 27 місце серед 131 країн [9]. Падіння рейтингу $\epsilon$ невтішним для країни 3 євроінтеграційним вектором руху.

Однак методика не є досконалою. Оскільки передбачає оцінку ринкової вартості лише тієї продукції, випуск якої регулюється ринком. Всю продукцію кінцевого споживання в національній економіці можна поділити на три групи. Перша - це "ринкова" продукція: товари і послуги, що перебувають в обігу на внутрішніх галузевих ринках. Другу групу утворює продукція, що виробляється для власного кінцевого споживання: продукція, яка виготовляється в господарствах населення для власного споживання; послуги 3 будівництва житла власними силами, послуги щодо проживання у 
власному житлі та ін. Третю групу утворює інша "неринкова" продукція: матеріальні блага та послуги, що надаються безоплатно, або за цінами, що не $\epsilon$ економічно обгрунтованими( безкоштовні освіта та медичне обслуговування, розвиток науки, культури, мистецтва, обороноздатності країни, підтримання громадського порядку) ін. Виробництво продукції, що утворює другу й третю групу, в кожній національній економіці регулюється не ринковим механізмом, а потребами їі резидентів та обсягами матеріальних ресурсів держави [4]

Українські вчені економісти запропонували свою формулу визначення «розміру внутрішнього ринку», яка розраховується на основі вартості лише "ринкової" продукції, що входить до першої групи.[5;6]

$$
\mathrm{VR}=\mathrm{BBП}+\mathrm{I}-\mathrm{E}-\text { Кксв }- \text { Вспд, (2) }
$$

де I- імпорт товарів і послуг; Е- експорт товарів і послуг; Кксв кінцеві колективні споживчі витрати; Вспд - вартість спожитої продукції домогосподарствами, що отримана з особистого .

За нашими розрахунками протягом 2010 - 2015 pp ,прослідковувалася тенденція до збільшення обсягу внутрішнього ринку споживчих товарів. Так, у 2015 році розмір внутрішнього ринку споживчих товарів становив 1539100,5 млн. грн. 32016 по 2018 рр, прослідковується тенденція до зменшення обсягу внутрішнього ринку споживчих товарів. У 2018 році обсяг внутрішнього ринку споживчих товарів становив 1234892 млн. грн.

Спираючись на твердження О.Пустовойта, що «національна економіка розвивається симетрично наростанню на внутрішньому ринку структурних змін у сукупному попиті та сукупній пропозиції на користь інноваційної та якіснішої продукції» [5] Отже, інтенсивність структурних змін у сукупному попиті на внутрішньому ринку національної економіки можна оцінити за допомогою показника дискреційного доходу. Величина дискреційного доходу відображає частину чистого доходу домогосподарств, яка може бути витрачена ними після задоволення потреб у споживанні товарів і послуг першої життєвої необхідності.

Оцінити утворення дискреційного доходу в економіці України, можна за допомогою даних динаміки грошових витрат домогосподарств на придбання продовольчої та непродовольчої продукції й оплату послуг протягом 2010 - 2018 рр.

За результатами дослідження, прослідковується невелика тенденція до скорочення витрат домогосподарств на придбання 
продовольчих товарів на 2,2\% протягом 2010-2018 pp., це означає що домогосподарства повільними темпами зменшували свої витрати на придбання продовольчих товарів. Для прикладу, в розвинених країнах ця величина становить 13-20\% від загального обсягу сукупних витрат. Водночас домогосподарства збільшили свої витрати на придбання непродовольчих товарів та послуг на протязі 2010-2013 pp. на 1,8\%, а 3 2016- 2018 рр. збільшили на 2\%. За нашими розрахунками у середньому на рік непродовольчі витрати господарств зростали лише на 4\%. Власне, цю величину можна вважати за середньорічні темпи зростання дискреційного доходу домогосподарств протягом 2010-2018 pp.

Інтенсивність структурних змін у сукупній пропозиції на внутрішньому ринку національної економіки можна дослідити за допомогою показників: обсяг роздрібного товарообігу та часток у його структурі вітчизняних та імпортних споживчих товарів. Зростання закупівель імпортної продукції на внутрішньому ринку свідчить, що національні виробники адекватно не реагують на зміни структури попиту споживачів. Так за даними Державної служби статистики України, на протязі 2010-2017 рр. на внутрішньому ринку України склались сприятливі умови для зростання товарного виробництва, свідченням цього $є$ зростання обсягу роздрібного товарооборот [3]. Так, якщо у 2010 р. величина роздрібного товарообороту становила 33249,7 млн.грн, а у 2017 р. - 586330,1 млн.грн. Отже, можна стверджувати, що споживчий попит зростав прискореними темпами на внутрішньому ринку України. Зростання споживчого попиту супроводжувалося зміною структури витрат споживання на користь інноваційних та якісніших товарів та послуг. Роздрібний товарооборот вітчизняних споживчих товарів скоротився на 8,3\% з 2010-2013 pp., порівняно з обсягом внутрішнього ринку. На протязі 2010-2015 рр. відбулося зростання на $1,8 \%$ роздрібного товарооборот вітчизняних споживчих товарів. 32016 - 2018 рр, знов прослідковується тенденція до скорочення на $1,5 \%$. А в цей самий період приріст роздрібний товарооборот імпортних споживчих товарів становив 1,6\%. Цей факт, стверджує, що внутрішній ринок вітчизняного товарного виробництва почав адаптацію до змін у споживчому попиті, а це вельми, актуально в умовах інтенсифікації інтеграційних процесів України до ЄС.

Висновки. Дослідження внутрішнього ринку $\epsilon$ досить актуальним в умовах інтенсифікації інтеграційних процесів України до ЄС. На сьогодні не існує єдиної визнаної методики, щодо визначення обсягу внутрішнього ринку. В результаті дослідження обсягу внутрішнього ринку споживчих товарів на протязі досліджуваних 
років прослідковується тенденція до зменшення обсягу починаючи 3 2016 р. Зважаючи на важливу роль внутрішнього ринку у розвитку національної економіки, існує потреба подальших досліджень у цьому напрямі та удосконалення методичних засад для різних груп продукції кінцевого споживання.

\section{Список використаних джерел}

1. Внутрішній ринок i торгівля України: структурноінституціональна трансформація:монографія /В.Д. Лагутін, Ю.М. Уманців, А.Г.Герасименко та ін.; за ред. В.Д.Лагутіна.-К.: Київ.нац.торг.-екон.ун-т, 2015.- 432 с.

2. Внутрішній ринок України в умовах дисбалансів між виробництвом і споживанням/ А. А. Мазаракі, В. Д. Лагутін // Економіка України. - 2016. - № 4. - С. 4-18.

3. Державна служба статистики України [Електронний ресурс]. Режим доступу: http://www.ukrstat.gov.ua/

4. Інститут економіки та прогнозування [Електронний ресурс]. Режим доступу: http://ief.org.ua/?page_id=1182

5. Пустовойт О.В. Інституційна природа економічних циклів. Досвід України : монографія / О.В. Пустовойт. - НАН України, ДУ «Інт екон. та прогнозув. НАН України». - Київ, 2016.-388 с.

6. Пустовойт О.В. Політика розвитку внутрішнього ринку споживчих товарів та Угода про асоціацію Україна - СС: спільність і суперечність завдань / О.В. Пустовойт // Економіка та прогнозування. - 2015. - №1. - С. 49-63.

7. Ринки реального сектора економіки України в інституціональному середовищі СОТ: кон'юнктура та інтеграція / [Точилін В. О., Осташко Т. О., Пустовойт О. В. та ін.]; за ред. В. О. Точиліна; НАН України; Ін-т екон. та прогнозув. - К., 2012. - 552 с.

8. Уманців Ю.М. Розвиток внутрішнього ринку споживчих товарів в Україні / Ю.М. Уманців, М.В. Катран // Бізнес Інформ. - 2017. - №8. - C. 271-275

9. Global Competetiveness report [Електронний ресурс] - Режим доступу: https://www.weforum.org/reports/global-competitiveness-report2016-2017/

10. World economic forum [Електронний pecypc] - Режим доступу: https://www.weforum.org/ 
Ю.В. Кіндзерський, доктор економічних наук, ДУ «Інститут економіки та прогнозування НАН України»

\section{КОНСЫЮМЕРИЗМ ЯК ПРИВНЕСЕНА ІДЕОЛОГІЯ ДЕГРАДАЦІЇ СУСПІЛЬСТВА, ДЕРЖАВИ, ЕКОНОМІКИ: ФЕНОМЕНОЛОГІЯ ПРОЯВУ В УКРАЇНІ}

Започаткування ринкових перетворень в Україні у 90-х рp. XX століття на тлі відкриття нею свого внутрішнього ринку призвело до подальшого стрімкого завоювання імпортом домінуючих позицій на ньому, зумовило швидке перенесення в країну стандартів і практик споживання 3 розвинених країн та сформувало в українському суспільстві відносно новий для нього (але не новий для розвинених суспільств) феномен консьюмеризму з усіма його негативними рисами і наслідками ${ }^{1}$, що набули своїх особливих відтінків на вітчизняному господарському і суспільно-ментальному грунті. Внаслідок привнесення ззовні культу (справедливіше казати - біча) споживацтва дуже швидко почали розвиватися процеси дегуманізації самої людини, десоціалізації і деградації держави у іiї стосунках із суспільством і бізнесом, аморалізації і криміналізації бізнесу, як в його середині між суб'єктами, так і по відношенню i до держави, i до найманих працівників.

Людина, вийшовши з радянської системи і отримавши у т.з. «західних демократіях» принизливу характеристику як «Ното Soveticus», практично одразу (в історичному вимірі), за лічені роки перетворилась (за термінологією Ф.Фукуями) на «Ноmo Consumens». Проте, на жаль, відстала вітчизняна економіка з такою ж швидкістю і якістю просто об'єктивно не могла (i ніколи б не змогла) трансформуватися під нові, вибагливі і великі потреби цього новоствореного типу людини. На тлі непристосованості та неспроможності власного виробництва до їх задоволення, яка зберігається і донині, не дивлячись на усі т.з. «радикальні ринкові реформи», започатковані державою, в економіці України сформувалась модель «збіднюючого» чи «виснажливого» розвитку [3], в якій основним способом задоволення нових завищених зкультивованих потреб суспільства став продаж на світових ринках

\footnotetext{
${ }^{1}$ Проблема консьюмеризму та деградації суспільства як основного його наслідку широко представлена у роботах відомих світових філософів, соціологів, економістів, серед яких варто особливо виділити Жана Бодрійяра [1] та Френсіса Фукуяму [2].
} 
власних недорогих ресурсів в обмін на дорогі іноземні товари масового вжитку. Це стало основою формування нееквівалентного товарного обміну між Україною та іншими (насамперед розвиненими) країнами і поряд 3 феноменом консьюмеризму в країні виник феномен «ресурсного прокляття».

Насиченість (насамперед завдяки імпорту) внутрішнього товарного ринку та широта товарного асортименту, відкриття перед населенням доступу до матеріальних благ сучасної західної цивілізації, на тлі відсутності у громадян, з одного боку, виваженої і раціональної культури споживання, а 3 іншого - високої продуктивності праці, сформували ряд суперечливих ефектів, які чималою мірою вплинули і на інституційні деформації, і на формування соціальної невдоволеності і соціальних конфліктів. У населення швидко розвинулась невгамовна «жага» до споживацтва, не підкріплена такою ж «жагою» до ефективної праці. У заможних верств, представників вищих щаблів влади і бізнесу це перетворилось у демонстративне, клептократичне, «елітне» споживання. У середніх і малозабезпечених верств це посилило відчуття власної бідності, нерівності і соціальної невдоволеності. Бідність роздвоїлась на реальну (ту, яка дійсно не дає людині задовольнити найелементарніші потреби) і віртуальну (ту, яка сформована культом споживацтва у вигляді бажання володіти усе більшою кількістю не зовсім потрібних людині речей i неспроможністю їх придбати). Віртуальна бідність почала усе більше i більше переважати над реальною, причому у всіх верствах населення.

Випереджаюче формування завищених споживчих запитів i культу споживацтва на тлі низькопродуктивного виробництва привело до чималих проблем у фінансовій сфері загалом, та інвестиційній зокрема. Не лише у населення, але і у влади, як відмічає В.Геєць, сформувався «стереотип поведінки споживання не за ресурсами $\mathrm{i}$ життя не за коштами» $[4$, с. 8$]$. Досить поширеним став міф, що добробут населення розвинених країн забезпечується завдяки постійному життю у борг. На державному рівні ці стереотипи трансформувались не у політику розвитку виробництва, а у політику постійних запозичень коштів на покриття дефіциту бюджету. Формування ж самого бюджету відбувалося, виходячи не 3 реально отриманих результатів економічної діяльності, не із запитів на модернізацію виробничого базису країни, а 3 «роздутих» запитів на споживання, як у формі соціальної підтримки населення, так і у вигляді безпосередньо державного споживання.

На тлі деградуючої економіки, намагаючись підтримувати уже такий, що швидко став звичним, рівень споживання, українська 
держава потрапила у «борговий зашморг» перед зарубіжними позичальниками, коли левова частка нових запозичень спрямовується на покриття зобов'язань за старими, решта - знову таки на підтримку споживання і соціальні зобов'язання держави, а не на розвиток виробництва, при цьому рівень обслуговування боргу за рахунок бюджету зростає, а реальна дохідна база бюджету звужується внаслідок постійної стагнації виробництва. Водночас міжнародні донори надання своїх позик супроводжують вимогами, реалізація яких Урядом часто відверто негативно відбивається на суспільних настроях, оскільки має наслідком звуження соціальних гарантій населенню та його збідніння [5].

Для населення споживання понад власні ресурси і життя у борг особливо характерно проявилося у поширенні споживчого кредитування. Його обсяги були зіставні із рівнем кредитування переробної промисловості. Ураховуючи, що споживчі кредити надавалися на непродовольчі високотехнологічні товари тривалого використання, причому переважно іноземного походження (автомобілі, побутова техніка і електроніка, засоби зв'язку), можна говорити, що такі кредити стали для вітчизняних галузей переробки суттєвим чинником їх пригнічення, а для іноземної продукції механізмом прискореного просування на внутрішній ринок, що не могло не позначитись на посиленні сировинного ухилу вітчизняної промисловості.

Корпоративний нефінансовий сектор економіки не став винятком у веденні своєї діяльності за рахунок боргів. За останнє десятиліття, за спостереженнями В.Зимовця та Н.Шелудько, його борг стрімко нарощувався: якщо у 2005 р. він майже не перевищував власний капітал, то до 2016 р. співвідношення між ними (боргова залежність) сягнуло 4,37 од. [6]. Надвисока боргова залежність, незначна роль банків у фінансуванні та нагромадженні капіталу поряд із поширенням тіньової діяльності та офшорних схем виведення коштів $з$ країни, як вказують дослідники, є ознаками деформованої «квазіринкової» фінансової моделі ведення бізнесу в Україні. Вона утворилась внаслідок вищезгаданих деформацій інституційної системи та системи прав власності як іiі ключової складової. У даному контексті це проявляється, по перше, у слабкому захисту прав кредиторів та, по друге, у недовірі до банківської системи․․

\footnotetext{
2 Зокрема, за даними Світового Банку, станом на червень 2017 р. в Україні за завершенням процедур банкрутства суб'єктів кредиторам відшкодовувалось в середньому 7,5\% суми вкладених ними коштів, тоді як в Норвегії та Японії - 92\%, Великій Британії - 88,6\%, Німеччині - 84,4\%, США - 78,6\%, Польщі - 60,6 \%. Див.: Doing business: Resolving Insolvency. The World Bank Group. URL: http://www.doingbusiness.org/data/exploretopics/resolving-insolvency.
} 
Утвердження у суспільстві пріоритету поточного споживання над відкладеним інвестиційним на тлі високих ризиків постійного переділу та неправомірного відчуження власності, відкритості внутрішнього ринку і відсталості виробництва, безпосередньо позначилось на відтворювальних процесах у виробництві. Незадовільний рівень захисту прав інвесторів зробили інвестиції у виробництво непривабливими для бізнесу, а рівень валового нагромадження основного капіталу наднизьким ${ }^{3}$. Криза відтворення набула рис перманентності i стійкого поглиблення, що підтверджується постійно наростаючим рівнем зносу основних засобів в економіці та промисловості ${ }^{4}$ і зрештою може обернутися повним колапсом економіки уже в найближчій перспективі.

У результаті деструктивних трансформацій у системі прав власності й зумовленого ними переважання поточного споживання над інвестиційним на тлі поширення західних споживчих практик та збереження низької культури виробництва і якості управління ним, відбулося не лише інвестиційне «виснаження» економіки, але й, що більш важливо, набуття нею неспроможності до відтворення на інноваційній основі.

Успадкований від колишнього СРСР високий рівень освіченості населення виявився незатребуваним у процесах переділу власності і не став перешкодою для формування олігархічного капіталу, що згодом дало поштовх до руйнації і деградації освітнього потенціалу країни, оскільки мотиваційна основа його формування була суттєво підірвана несправедливим розподілом власності і великим розшаруванням суспільства за рівнем статків. Освіта і високий рівень освіченості перестали бути для пересічної людини головним фактором високих статків, гарантії отримання високооплачуваної роботи за фахом, соціальної і моральної задоволеності своїм життям. Відповідно спроможність економічної системи до генерування та імплементації інновацій суттєво послабшала.

Ще одним не менш важливим чинником такого послаблення виявилася непристосованість системи організації вітчизняної науки до нових умов господарювання - до потреб як нових власників підприємств, так і до запитів ринку на інноваційні товари і послуги.

\footnotetext{
${ }^{3}$ Впродовж останніх п'ятнадцяти років ВНОК (валове нагромадження основного капіталу) лише у 20062008 рр. наближалось до прийнятої у світовій практиці мінімально допустимої норми у 25\% ВВП для забезпечення процесу розширеного відтворення та інтенсивної модернізації виробництва. В інші роки воно було в межах $16-19 \%$.

${ }^{4}$ Впродовж останніх півтора десятиліття знос основних засобів зріс мало не вдвічі, з 45\% у 2001 р. до $83,5 \%$ у 2016 р. в економіці, та з 52\% у 2001 р. до $77 \%$ у 2016 р. в промисловості. Ще вищій рівень зносу спостерігається у секторах енергетичної і комунальної інфраструктури, зокрема у виробництві та розподіленні електроенергії, газу - $82,6 \%$, водопостачанні $-62 \%$.
} 
Пам'ятаючи, що інновації розглядаються підприємцем насамперед як джерело отримання прибутків за умови, якщо інші джерела відсутні або себе вичерпали, слід зазначити, що незахищеність і розмитість прав власності в Україні призвели до появи феномену перманентного генерування джерел прибутків, пов'язаних не 3 впровадженням інновацій, а 3 переділом власності і національного багатства країни, чому без сумніву посприяла споживацька психологія, сформована у суспільстві як на рівні держави, так і на рівні суб'єктів господарювання i пересічних громадян. Зрештою це обумовило хронічну кризовість i деградацію української економіки. Тому першим і головним кроком для виходу з цієї кризовості має стати відмова від суспільної ідеології невгамовного i невиправданого споживацтва, його раціоналізація, збалансування з наявними виробничими і ресурсними можливостями країни. Проте питання як це зробити і хто це зробить залишається відкритим для подальшої дискусії і наукового пошуку.

\section{Список використаних джерел:}

1. Бодрийяр Ж. Общество потребления. Его мифы и структуры / Пер. с фр., послесл. и примеч. Е.А. Самарской. - Москва: Республика; Культурная революция, 2006. - 269 с.

2. Фукуяма Ф. Конец истории и последний человек / Перевод с англ. М.Б. Левина. - Москва: ООО "Издательство АСТ", 2004. 588 с.

3. Кораблін С. Модель відстаючого зростання: економічні фактори та наслідки для України // Економіка і прогнозування. - 2016. № 2. - C. 74-85.

4. Геєць В. Інституційна обумовленість інноваційних процесів у промисловому розвитку України // Економіка України. - 2014. № 12. - С. 4-19.

5. Богдан Т. Зовнішнє боргове навантаження та виклики для валютно-фінансової політики України // Економіка України. 2016. -№ 7. - C. 21-32.

6. Зимовець В.В., Шелудько Н.М. Боргове навантаження та інвестиційна дисфункція в реальному секторі економіки України // Економіка промисловості. - 2017. - № 3 (79). - С. 82-95. 
Корнєєва Ю.В.,

к.е.н., ДННУ «Академія фінансового управління»

\section{КЛАСИФІКАЦІЯ ІНВЕСТИЦІЙ В УКРАЇНІ: ОБЛІКОВИЙ ПІДХІД}

Закон України «Про інвестиційну діяльність» визначає, що інвестицією є всі види майнових та інтелектуальних цінностей, що вкладаються в об'єкти підприємницької та інших видів діяльності, в результаті якої створюється прибуток (доход) та/або досягається соціальний та екологічний ефект [1]. Податковий підхід до трактування категорії інвестиція визначено у Податковому Кодексу України, що закріплює за інвестиціями наступне тлумачення господарські операції, які передбачають придбання основних засобів, нематеріальних активів, корпоративних прав та/або цінних паперів в обмін на кошти або майно [2]. Згідно з Міжнародними стандартами бухгалтерського обліку [3], що відображають обліковий підхід до визначення категорії, інвестицією $є$ актив, утримуваний підприємництвом для приросту капіталу через розподіл доходів (наприклад, відсотків, роялті, дивідендів та ренти), для збільшення вартості капіталу або інших вигод для підприємства інвестора, отриманих, скажімо, завдяки торговельним відносинам.

Об'єктом інвестування може виступати нерухоме майно, у тому числі підприємство як майновий комплекс, цінні папери та інтелектуальна власність. Відповідно до об'єкта інвестиції класифікують як фінансові інвестищіï, що здійснюються у різні фінансові інструменти, такі як цінні папери, депозити, цільові банківські вклади, та реальні інвестииї, що передбачають вкладання коштів у матеріальні активи, а саме - будівлі, споруди, обладнання тощо, та нематеріальні активи - патенти, ліцензії, «ноу-хау», науководослідні і дослідно-конструкторські роботи у вигляді документації тощо. Шарп У., Александер Г., Бейлі Дж. до реальних інвестицій відносять інвестиції в який-небудь тип матеріально відчутних активів (земля, обладнання, заводи), до фінансових, відповідно, контракти, записані на папері (акції, облігації) [4]. Г. Вайнріх віділяє матеріальні інвестиції - інвестиції у будівлі, споруди, обладнання, запаси матеріалів, та нематеріальні інвестиції - інвестиції у підготовку кадрів, дослідження, рекламу, та фінансові інвестиції - як придбання акцій, облігацій та інших цінних паперів [5]. 
Гітман Л. Дж. та Джонк М. Д. пропонують фінансові інвестиції розділити на прямі інвестиції як форму вкладення, яка дає інвестору безпосереднє право власності на цінні папери чи майно (придбання акції, облігації, коштовної монети чи земельної ділянки інвестором задля збереження вартості грошей чи отримання доходу), та опосередковані - вкладення в портфель (набір цінних паперів або майнових цінностей) [6]. Бланк I. зазначає, що «прямі інвестиції передбачають пряму участь інвестора у виборі об'єктів інвестування й вкладення капіталу. Зазвичай прямі інвестиції здійснюються шляхом безпосереднього вкладення капіталу в статутні фонди інших підприємств. Непрямі інвестиції характеризують вкладення капіталу інвестора, опосередковане іншими особами (фінансовими посередниками)» [7]. Тож, фінансові інвестиції в залежності від мети інвестора розподіляють на прямі та портфельні.

Державні фінансові інвестииіï у Законі України Про інвестиційну діяльність визначено як інвестиції 3 боку держави (державного, місцевих бюджетів) капіталу (активів) у фондові та грошові фінансові інструменти, статутні капітали юридичних осіб 3 метою отримання доходу та/або зростання (збереження) вартості капіталу. Державні фінансові інвестиції охоплюють внесення бюджетних коштів у дохідні види фінансових інструментів, внесення бюджетних коштів до статутних фондів державних або комунальних підприємств у формі капітальних вкладень, внесення бюджетних коштів у дохідні види фондових інструментів [1].

Державні реальні інвестиції - вкладення, здійснювані органами влади та управління за рахунок коштів бюджетів, позабюджетних фондів і позикових коштів, а також державними підприємствами й установами за рахунок власних і позикових коштів у матеріальні та нематеріальні активи. Стаття 2 пункту 20 Бюджетного кодексу України визначає державні капітальні вкладення як капітальні видатки державного бюджету (надання кредитів 3 державного бюджету), що спрямовуються на створення (придбання), реконструкцію, технічне переоснащення основних засобів державної власності, очікуваний строк корисної експлуатації яких перевищує один рік [8].

Класифікаційна матриця наукової категорії «інвестиція», розроблена на основі Закону України «Про інвестиційну діяльність», а також положень Бюджетного Кодексу України представлена у табл.. 1. 
Таблиия 1.

\section{Класифікаційна матриця наукової категорії «інвестиція»}

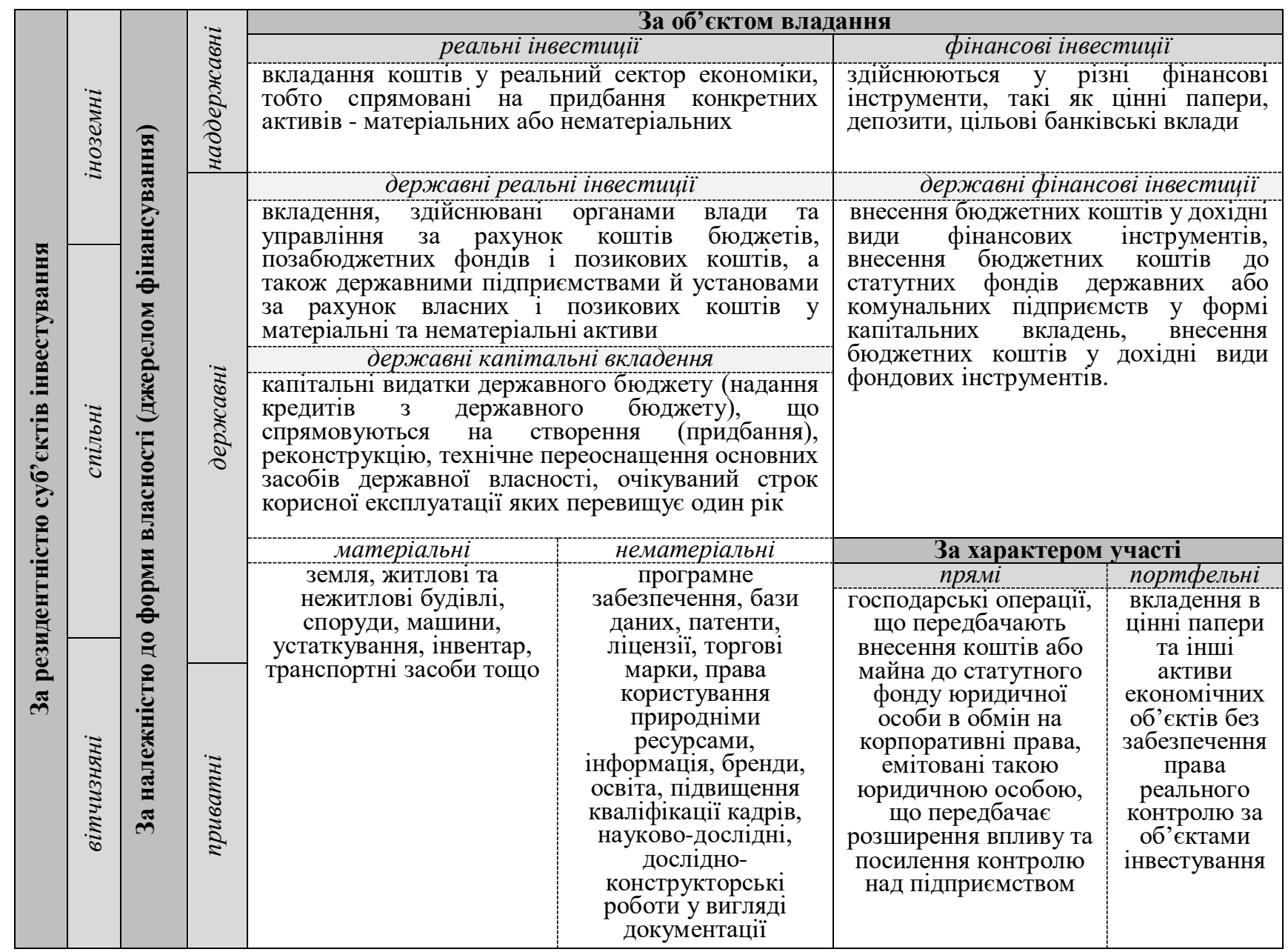

Джерело: узагальнено і систематизовано автором на основі $[1,8]$.

\section{Згідно чинного законодавства України капітальні інвестиції} визначені як інвестиції, що спрямовуються у будівництво, виготовлення, реконструкцію, модернізацію, придбання, створення необоротних активів (включаючи необоротні матеріальні активи, призначені для заміни діючих, i устаткування для здійснення монтажу), а також авансові платежі для фінансування капітального будівництва [9]. Згідно з методичними поясненнями Держстат України капітальні інвестиції визначені як інвестиції у придбання або виготовлення власними силами для власного використання матеріальних та нематеріальних активів [10]. Згідно 3 підходом Т. Майорової, капітальні інвестиції розглядаються як витрати на будівництво нових, розширення, реконструкцію та технічне переобладнання наявних основних засобів виробничого та 
невиробничого призначення [11]. Водночас, витрати на капітальний ремонт будівель, споруд та інших видів основних фондів до капітальних вкладень не зараховують, тому ці витрати до інвестиційних не відносять. До капітальних інвестицій відносять лише капітальні видатки у частині капітального будівництва та реконструкції чи реставрації. Шевчук В.Я. та Рогожин П.С. визначають капітальні інвестиції як видатки на створення, розширення, реконструкцію, модернізацію (технічне переоснащення) основних виробничих фондів чи основного капіталу [12]. В. Вергун визначає капітальні інвестиції як господарські операції, що передбачають придбання будинків, споруд, інших об'єктів нерухомої власності, інших основних фондів та неатеріальних активів, які підлягають амортизації [13]. Валовим капіталоутворенням для основного капіталу $\epsilon$ загальна сума капіталу, інвестованого у заводи, склади, офіси, споруди тощо [14].

Класифікуючи інвестиції за способом обліку засобів виділяють валові інвестиції (вкладення в основний виробничий капітал, які становлять загальний обсяг інвестування спрямованого на нове будівництво, придбання засобів виробництва та приріст товарноматеріальних запасів, капітальний ремонт будівель і споруд тощо певний період) та чисті інвестиції (сума валових інвестицій без суми амортизаційних відрахувань основного капіталу за певний період).

Обліковий підхід до класифікації інвестицій згідно з чинним законодавством України відображено у табл.2. У податковому обліку за класифікаційну ознаку береться як об'єкт інвестування (капітальні інвестиції та фінансові інвестиції), так і характер застосування капіталу (реінвестиції). Водночас до уваги береться характер участі інвестора для розподілу фінансових інвестицій на прямі та портфельні інвестицій. В основі класифікаційного розподілу інвестицій у бухгалтерському обліку домінує витратний підхід. До уваги береться об'єкт інвестування, водночас для капітальних інвестицій додається класифікаційна ознака - джерело надходження коштів (централізовані капітальні інвестиції, нецентралізовані капітальні інвестиції), а для фінансових інвестицій - часові межі (довгострокові, поточні). 
Класифікація інвестицій в Україні: обліковий підхід

\begin{tabular}{|c|c|c|c|c|}
\hline \multicolumn{5}{|c|}{ Податковий облік } \\
\hline капітальні інвестиції & \multicolumn{2}{|c|}{ реінвестиції } & \multicolumn{2}{|c|}{ фінансові інвестииї } \\
\hline \multirow{3}{*}{$\begin{array}{l}\text { господарські операції, що } \\
\text { передбачають придбання } \\
\text { будинків, споруд, інших } \\
\text { об'єктів } \quad \text { нерухомої } \\
\text { власності, } \quad \text { інших } \\
\text { основних засобів і } \\
\text { нематеріальних активів, } \\
\text { що подлягють } \\
\text { амортизації п }\end{array}$} & \multirow{2}{*}{\multicolumn{2}{|c|}{$\begin{array}{l}\text { господарські операції, що } \\
\text { передбачають здійснення } \\
\text { капітальних або фінансових } \\
\text { інвестицій за рахунок } \\
\text { прибутку, отриманого від } \\
\text { інвестиційних операцій }\end{array}$}} & \multicolumn{2}{|c|}{ 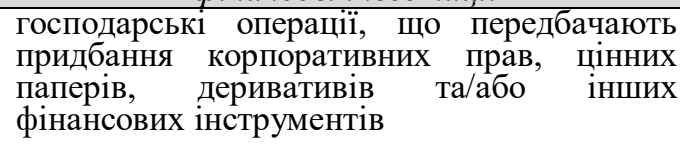 } \\
\hline & & & прямі інвестичиї & $\begin{array}{c}\text { портфельні } \\
\text { інвестииіі }\end{array}$ \\
\hline & & & $\begin{array}{l}\text { господарські шо } \\
\text { операції, } \\
\text { передбачають } \\
\text { внесення коштів або } \\
\text { майна в обмін на } \\
\text { корпоративні права, } \\
\text { емітовані } \\
\text { юридичною особою } \\
\text { при їх розміщенні } \\
\text { такою особою }\end{array}$ & $\begin{array}{l}\text { господарські що } \\
\text { операції, } \\
\text { передбачають цінних } \\
\text { купівлю дюр цінивів } \\
\text { паперів, дериватих фінансових } \\
\text { та інших фанти кошти на } \\
\text { активів за конт або } \\
\text { фондовому ринку } \\
\text { біржовому } \\
\text { товарному ринку }\end{array}$ \\
\hline \multicolumn{5}{|c|}{ Бухгалтерський облік } \\
\hline \multicolumn{2}{|c|}{ капітальні інвестииії } & \multicolumn{3}{|c|}{ фінансові інвестииії } \\
\hline \multirow{3}{*}{\multicolumn{2}{|c|}{$\begin{array}{l}\text { витрати на будівельно-монтажні роботи, } \\
\text { придбання будівель або їх частин, обладнання, } \\
\text { інструменту, інвентарю, інші капітальні роботи і } \\
\text { витрати на проектно-пошукові роботи, } \\
\text { геологорозвідувальні і бурові роботи, а також } \\
\text { витрати на відведення земельних ділянок і } \\
\text { переселення у зв'язку } 3 \text { будівництвом, на } \\
\text { підготовку кадрів для підприємств, що будуються, } \\
\text { та ін. }\end{array}$}} & \multicolumn{3}{|c|}{$\begin{array}{l}\text { активи, які утримуються підприємством з метою } \\
\text { збільшення прибутку (відсотків, дивідендів } \\
\text { тощо), зростання вартості капіталу або інших } \\
\text { вигод для інвестора }\end{array}$} \\
\hline & & \multicolumn{2}{|c|}{ довгострокові } & nоточнi \\
\hline & & \multirow{3}{*}{\multicolumn{2}{|c|}{$\begin{array}{l}\text { утримуються } \\
\text { підприємством на } \\
\text { період більше одного } \\
\text { року, а також усі } \\
\text { 1нвестиції, які не можуть } \\
\text { бути вільно реалізовані } \\
\text { в будь-який момент }\end{array}$}} & \multirow{3}{*}{$\begin{array}{l}\text { утримуються } \\
\text { підприємством на } \\
\text { строк, що не } \\
\text { перевищує один рік, і } \\
\text { які можуть бути вільно } \\
\text { реалізовані в будь- } \\
\text { який момент }\end{array}$} \\
\hline \multicolumn{2}{|c|}{$\begin{array}{c}\text { Капітальні інвестииіі в необоротні матеріальні } \\
\text { активи - }\end{array}$} & & & \\
\hline \multicolumn{2}{|c|}{$\begin{array}{l}\text { витрати на будівництво, реконструкцію, } \\
\text { модернізацію (інші поліпшення, що збільшують } \\
\text { первісну (переоцінену) вартість), виготовлення, } \\
\text { придбання об'єктів матеріальних необоротних } \\
\text { активів (у томучислі необоротних матеріальних } \\
\text { активів, призначених для заміни діючих, і } \\
\text { устаткування для монтажу), що здійснюються } \\
\text { підприємством }\end{array}$} & & & \\
\hline $\begin{array}{c}\text { иентралізовані } \\
\text { капітальні інвестиції }\end{array}$ & $\begin{array}{c}\text { нецентралізовані } \\
\text { капітальні інвестиціі }\end{array}$ & \multicolumn{3}{|c|}{$\begin{array}{c}\text { фінансові інвестиції, що здійснюються } \\
\text { суб'єктами господарювання державного } \\
\text { сектору }\end{array}$} \\
\hline \multirow[t]{3}{*}{$\begin{array}{l}\text { кошти, які асигнують на } \\
\text { капітальне будівництва } \\
3 \text { державного бюджету }\end{array}$} & \multirow{3}{*}{$\begin{array}{l}\text { визначаються планами } \\
\text { підприємств, населення } \\
\mathrm{i} \text { здійснюються за } \\
\text { рахунок їхніх власних } \\
\text { коштів. }\end{array}$} & \multicolumn{3}{|c|}{$\begin{array}{l}\text { активи, які утримуються (контролюються) } \\
\text { суб'єктом державного сектору з метою отримання } \\
\text { економічних вигід від їх володіння }\end{array}$} \\
\hline & & \multicolumn{2}{|r|}{ довгострокові } & поточні \\
\hline & & & $\begin{array}{l}\text { ансові інвестиції зі } \\
\text { оком погашення на } \\
\text { б балансу більше } \\
\text { надцяти місяців, що } \\
\text { имуються суб'єктом } \\
\text { жавного сектору не } \\
\text { продажу }\end{array}$ & $\begin{array}{l}\text { фінансові інвестиції зі } \\
\text { строком погашення на } \\
\text { дату балансу не більше } \\
\text { дванадцяти місяців, які } \\
\text { призначені до продажу } \\
\text { i можуть бути вільно } \\
\text { реалізовані у будь- } \\
\text { який момент }\end{array}$ \\
\hline
\end{tabular}

Джерело: узагальнено і систематизовано автором на основі [2, 15-19].

Пункт 14.1.81. статті 14. Податкового кодексу України ${ }^{5}$ визначає капітальні інвестищії як господарські операції, що передбачають придбання будинків, споруд, інших об'єктів нерухомої власності, інших основних засобів і нематеріальних активів, що підлягають

\footnotetext{
${ }^{5}$ Податковий кодекс України / Відомості Верховної Ради України (ВВР). 2011. № 13-14. № 15-16. № 17. с Пункт 14.1 статті 14. / URL: https://zakon.rada.gov.ua/laws/show/2755-17.
} 
амортизації; фінансові інвестиції як господарські операції, що передбачають придбання корпоративних прав, цінних паперів, деривативів та/або інших фінансових інструментів; а реінвестиції як господарські операції, що передбачають здійснення капітальних або фінансових інвестицій за рахунок прибутку, отриманого від інвестиційних операцій. Фінансові інвестиції, згідно цього документу поділяються на прямі інвестиції - господарські операції, що передбачають внесення коштів або майна в обмін на корпоративні права, емітовані юридичною особою при їх розміщенні такою особою; та портфельні інвестииії - господарські операції, що передбачають купівлю цінних паперів, деривативів та інших фінансових активів за кошти на фондовому ринку або біржовому товарному ринку. Фінансові державні інвестиції у бюджетному процесі визначені як внески у статутні капітали суб'єктів господарювання відповідно до Коду економічної класифікації видатків бюджету (КЕКВ) 3210 «Капітальні трансферти підприємствам (установам, організаціям)» [2, 19].

\section{Список використаних джерел}

1. Про інвестиційну діяльність : Закон України від 18.09.1991 № 1560-XII / BP України. http://zakon.rada.gov.ua/laws/show/1560-12.

2. Податковий кодекс України / Відомості Верховної Ради України (BBP). 2011. № 13-14. № 15-16. № 17. Пункт 14.1 статті 14. / URL: https://zakon.rada.gov.ua/laws/show/2755-17.

3. Міжнародні стандарти бухгалтерського обліку 2000 / Пер. $з$ англ. К. : ФПБАУ, 2000. 1272 с.

4. Шарп У., Александер Г., Бэйли Дж. Инвестиции / пер. с англ. М.: Инфра-М, 2003. С. 16.

5. Вайнрих Г., Хоффман У. Планирование и анализ инвестиций / под ред. Фалько С.Г. пер. с нем. М. : Правление общества «Знание», $1992.113 \mathrm{c}$.

6. Гитман Л., Джонк М. Основы инвестирования : пер. с англ. / М. : Дело, 1997. С. 10.

7. Бланк И. А. Инвестиционный менеджмент. К. : Эльга-Н, НикаЦентр, 2001. С. 24.

8. Про Бюджетний Кодекс України : Закон від 08.07.2010 № 2456. / Відомості Верховної Ради України (ВВР). 2010. № 50-51. ст.572. URL: http://zakon.rada.gov.ua/laws/show/2456-17.

9. Про затвердження Національного стандарту N 3 «Оцінка цілісних майнових комплексів» : Постанова Кабінету Міністрів 
України; Стандарт від 29.11.2006 № 1655. URL: http://zakon.rada.gov.ua/laws/term/11899:2692.

10. Державна служба статистики України: офіційний сайт. URL: http://www.ukrstat.gov.ua.

11. Майорова Т. В., Крук В.В., Шевчук Я.В. Капітальні інвестиції : мутність та проблеми реалізації в кризових умовах. Інвестиції: практика та досвід. 2015. № 21. С. 14.

12. Шевчук В.Я., Рогожин П.С. Основи інвестиційної діяльності. К.: "Генеза", 1997. С. 6.

13. Вергун В.А., Ступницький O.I., Коверда В.M., Волковинська Т.В. Інститути спільного інвестування в умовах глобалізації світових фінансових ринків: монографія. Київ: Видавничо-поліграфічний центр «Київський інверситет», 2009. C. 484.

14. Гіл. Ч. Міжнародний бізнес. Київ: Видавництво Соломії Павличко «Основи», 2001. С. 250.

15. Про затвердження Положення (стандарту) бухгалтерського обліку 12 «Фінансові інвестиції»: Наказ Міністерства фінансів України. № 91 від 26.04.2000. URL: https://zakon.rada.gov.ua/laws/show/z0284-00.

16. Про затвердження Положення (стандарт) бухгалтерського обліку 7 "Основні засоби": Наказ Міністерства фінансів України № 92. від 27.04.2000 p. URL: https://zakon.rada.gov.ua/laws/show/z0288-00.

17. Про затвердження деяких національних положень (стандартів) бухгалтерського обліку в державному секторі та змін до національних положень (стандартів) бухгалтерського обліку в державному секторі: Наказ Міністерства фінансів України. № 568 від 18.05.2012. URL: https://zakon.rada.gov.ua/laws/show/z090112/ed20170124\#n95.

18. Про затвердження Змін до деяких нормативно-правових актів Міністерства фінансів України з бухгалтерського обліку: Наказ Міністерства фінансів України № 1163. від 25.11.2014. URL: https://zakon3.rada.gov.ua/laws/show/z1603-14.

19. Про затвердження Інструкції щодо застосування економічної класифікації видатків бюджету та Інструкції щодо застосування класифікації кредитування бюджету: Наказ Міністерства фінансів України №133 від 12 березня 2012. URL: https://zakon.rada.gov.ua/laws/show/z0456-12\#n18. 
Крюкова I.O.,

к.е.н, доцент, Державний університет інфраструктури та технологій

\title{
РОЛЬ ЛОГІСТИКИ У СУЧАСНИХ СВІТОВИХ ТЕНДЕНЦІЯХ ЕКОНОМІЧНОГО РОЗВИТКУ
}

\author{
«Розробляти життєздатні стратегії можна \\ лише розглядаючи різні альтернативи" \\ Франк Аппель[10, С.45].
}

Ознакою економіки останніх років $є$ зростання ролі логістики $\mathrm{i}$ логістичних об'єднань. Навіть в умовах економічної кризи, в Україні не зупиняється розпочате раніше будівництво логістичних центрів, виділяються кошти на реконструкцію доріг і транспортних терміналів, а експерти прогнозують прискорений розвиток контрактної логістики.

Аналіз публікацій та досліджень останніх років свідчить про те, що проблема управління логістичними процесами є досить актуальною [1-10]. Сучасним логістичним концепціям присвячено роботи Бауэрсокса Д. Дж., Клосса. Д. Дж., Стока Дж.Р., Ламберта Д.М., Гаджинського А.М., Смирнова Е.А., Уварова С.А., Кальченко А.Г., Крикавського Є.В., Чухрай Н.І., Окландера М.А., Лариної Р.Р.

Мета логістичної системи - забезпечення доставки продукції у задане місце в потрібній кількості й асортименті у максимально можливому ступені підготовлених до виробничого чи особистого споживання при заданому рівні витрат[ 1, С.64].

Ключовими складовими логістичної системи, управління якою забезпечує конкурентоспроможність підприємства на ринку, $\epsilon$ логістична інфраструктура, логістична інформація, управління запасами, транспортування, складське господарство, вантажопереробка й упаковка[ 1, C.65].

Перспективи логістичного потенціалу підприємств, зайнятих у цих сферах економічної діяльності, тісно пов'язані із загальними сучасними тенденціями світового економічного розвитку.

Група компаній «Deutsche Post DHL» опубліковала футурологічне дослідження «Погляд у майбутнє: логістика-2050". В дослідженні визначено 5 концепцій логістики майбутнього та їх вплив на розвиток торгівлі і бізнесу в цілому.

«Як провідний провайдер в індустрії глобального значення, ми вважаємо себе відповідальними за активне дослідження соціальних i 
економічних проблем, що впливають на майбутнє людства», - зазначив генеральний директор «Deutsche Post DHL» Франк Аппель[10, C.46].

Дослідження «Логістика-2050», доповнене серією різнопланових есе, стало третім дослідницьким проектом серії «Погляд у майбутнє», представленим Deutsche Post DHL. За допомогою цих прогресивних досліджень група німецьких компаній прагне відкритого діалогу щодо ключових проблем, які будуть впливати на навколишній світ у найближчі десятиліття.

«В останні роки наш світ змінюється усе швидше. У таких складних економічних, політичних та соціальних умовах створення лінійних прогнозів практично неможливе. Передбачити, яким стане життя навколо нас, усе складніше - для цього необхідно розширювати горизонти та розглядати можливі альтернативні шляхи розвитку. Розробляти життєздатні стратегії і обирати правильний курс можна тільки із розумінням різних перспектив», - зазначив Франк Аппель на презентації дослідження «Погляд у майбутнє: логістика-2050» [10, C.46].

Ключовим результатом дослідження стала розробка 5 вірогідних сценаріїв майбутнього, які відображають, наскільки різними можуть стати шляху розвитку економіки до 2050 року з урахуванням ступеня глобалізації, економічного та соціального розвитку, переважаючих технологічних стандартів і стану навколишнього середовища. Це довгострокові та у деяких випадках радикальні версії того, як може вигля дати світ майже через 40 років.

Результати дослідження засновані на очікуваннях і прогнозах експертів 3 різних сфер. У дослідженні брали участь 42 відомих експерта, в тому числі Клаус Тепер (колишній міністр з охорони навколишнього середовища Німеччини та директор Програми ООН 3 навколишнього середовища), Фатіх Біроль (головний економіст Міжнародного енергетичного агентства) i Міхаель тен Хомпель (керуючий директор Інституту Фраунгофера 3 руху матеріалів та логістики). Над футуристичними сценаріями розвитку логістики для Deutsche Post DHL також працювали провідні фахівці таких організацій, як Всесвітній економічний форум, дослідницький інститут Gesellschaft fbr Konsumforschung (GfK), Інститут Рокі Маунтін, Копенгагенський інститут футурології, Всесвітня рада підприємців зі сталого розвитку та Грінпіс Інтер нешнл.

Відправною точкою для дослідження став глибинний аналіз ключових факторів та їх зв'язку з актуальними тенденціями в економіці і логістиці. На відміну від класичних методик ізольованого аналізу та прогнозування, обраний за участі провідних експертів підхід до 
розробки сценаріїв дозволив виділити потенційні напрямки розвитку таких факторів і прив'язати їх до кожного із сценаріїв. Далі можливі напрями обговорювалися і оцінювалися у форматі робочих груп, що дозволио створити декілька варіантів комплексного прогнозу розвитку логістики на найближчі десятиліття.

Сценарій 1: Світ на межі колапсу.

Світ живе за законами матеріальних цінностей i неконтрольованого масового споживання. Цей нестійкий шлях заснований на нещадному використанні природних ресурсів, що прискорює зміни клімату і призводить до почастішання стихійних лих.

У світі, для якого характерний бурхливий ріст, попит на логістичні та транспортні послуги різко збільшується. Глобальна транспортна система забезпечує швидкий обмін товарами між центрами споживання. По суті, це інерційний сценарій. Азія стає новим економічним центром, і навколо неї формується нова організація вільної торгівлі, що діє паралельно СОТ. Глобальний середній клас безконтрольно споживає. Чого варті 4 млрд. автомобілів на дорогах планети до 2050 року? Відомо, чого вони варті, - розробку родовищ розпочато у середині 2040-х навіть у Гренландії та Антарктиці.

Ще один наслідок нестримного споживання - глобальне потепління (до 2100 року на 6 градусів за Цельсієм) [10, С.47]. Це турбує суспільство настільки, що до середини 2040-х з'являються групи екологічних терористів, але й бізнес стри- вожений: посилюються кліматичні зміни, які часто порушують ланцюжки поставок, що створює проблеми для логістичних компаній.

Сценарій 2: Суперефективність у супермістах.

Мегаполіси перетворюються на світові центри управління. Саме тут народжуються ініціативи стосовно переходу до екологічному шляху розвитку, від якого виграють насамперед самі міста. Щоб вирішити проблеми, пов'язані із зростанням міст, зокрема щодо перенаселеності та забруднення навколишнього середовища, мегаполіси ефективно розвиваються у напрямку співпраці. Іншими словами, виробництво та обслуговування зазнали революційних змін за рахунок роботизації - багато продуктів тепер не купуються, а беруться в оренду (у тім числі - авто), розвинений громадський транспорт, комп'ютерні системи управління зменшили затори на дорогах.

Глобальна транспортна система, що включає в себе наземні, морські, повітряні і навіть космічні перевезення, допомогла створити значущі торгові зв'язки між численними мегаполісами у всьому світі. 
Космічні літаки здійснюють надшвидкісні перевезення між континентами, працюють гігантські автомобільні потяги.

На плечі логістичних компаній лягло управління міськими транспортними потоками, комунальними службами, системне обслуговування аеропортів, лікарень і торгових центрів. Міжнародні організації типу СОT і OOH, а також транснаціональні корпорації взяли на себе у «глобальному місті» багато функцій національних урядів. Затьмарює майбутнє той факт, що міста розвиваються за рахунок села, яке бідніє - це породжує соціальну напругу.

Сценарій 3: Індивідуалізований спосіб життя

Цей сценарій описує світ, в якому широко розповсюджене індивідуалізоване споживання. Людина отримує можливість створювати і розробляти власні продукти, і чималу роль у цьому процесі відіграють 3D-принтери. Така тенденція призводить до зростання регіональних торгових потоків - глобальними залишаються тільки торгівля сировиною і передача даних.

Кастомізація i регіональне виробництво супроводжуються децентралізацією енергоспоживання та управління інфраструктурою. Для логістики це означає зниження попиту на перевезення готової продукції та напівфабрикатів на великі відстані. Зате розвинена регіональна логістика та високоефективна система «останньої милі» стають важливими факторами успіху у бізнесі.

Логістичні провайдери займаються організацією усього фізичного ланцюжка творення доданої вартості, а також керують потоками зашифрованих даних для передачі схем речей, які будуть друкуватися у 3D-принтерах. Третина сімей із середнього класу буде мати вдома принтер, придатний не тільки для виготовлення дрібних предметів, але навіть великих - велосипедів, меблів тощо.

На зміну Інтернету приходить Аутернет - у кожної речі своя RFID-мітка, за допомогою якої річ взаємодіє 3 глобальною інформаційною мережею. Проблема браку ресурсів вирішується за рахунок розвитку переробки відходів.

Сценарій 4: Послаблюючий протекціонізм

Згідно $з$ цим сценарієм, у результаті економічних потрясінь процес глобалізації змінився захистом національних ринків i виникненням численних протекціоністських бар'єрів. Розвиток технологій сповільнюється. Високі ціни на енергоносії і величезний їх дефіцит призводять до міжнародних конфліктів і боротьби за джерела ресурсів.

На логістичній галузі позначаються проблеми, що виникли внаслідок спаду світової торгівлі, а також наступної регіоналізації 
ланцюжків створення доданої вартості. Уряди розглядають логістику як стратегічну індустрію. Оскільки напруженість відносин між деякими регіонами i країнами значно посилюється, логістичні провайдери у нейтральних країнах виступають у ролі посередників у міжнародній торгівлі. Всі країни створюють свої власні аналоги GPS i ГЛОНАСС.

Сценарій 5: Глобальна стійкість - локальна адаптація

Цей сценарій передбачає високий рівень споживання внаслідок здешевлення та автоматизації виробництва. Однак підсилюються зміни клімату і часті катастрофи негативно позначаються на логістичних та виробничих ланцюжках, що призводить до регулярних порушень поставок. Особливістю нової економічної парадигми стає перехід від прагнення до максимальної ефективності до захисту «слабких місць» $\mathrm{i}$ підвищенню стійкості.

Радикальне зміщення фокусу на резервні системи виробництва та регіональні ланцюжки поставок дозволяє глобальній економіці вистояти у складний період. У 2050 році за регіоналізації торгівлі основою економічної системи стає логістичний сектор, основним пріоритетом якого є безпека ланцюжків постачань[10,C.50].

Логістиці добре, але світова економіка в цілому перебуває у стагнації, адже ті ресурси, які могли б йти на зростання, зараз задіяні на забезпечення безпеки та стабільності.

Всі ці світові економічні тенденції сягають своїм корінням ще тих змін, що були започатковані у останні десятиліття XX ст. Основні 3 них починалися 3 революції в інформаційних технологіях, i впровадженні персональних комп'ютерів, змін в державному регулюванні інфраструктури економіки, поширення філософії загального управління якістю, зростання партнерства й стратегічних союзів, структурних змін в організації бізнесу.

Висновки. У всіх п'яти запропонованих до уваги різних прогнозних сценаріях економічного розвитку є спільний фактор значно зросла роль логістики. У більшості з них попит на логістичні послуги стає істотно вищим, але конкретні ринкові умови і специфічні проблеми галузі у кожному випадку розрізняються.

Відповідно до сучасних тенденцій розвитку світової економіки, для логістичних процесів нині актуальним $є$ період інтеграції. Він характеризується об'єднанням логістичних функцій підприємства i його логістичних партнерів у так званий повний логістичний ланцюг ( закупівля-виробництво-розподіл-збут), а також управлінням матеріальними й супутніми потоками, створенням міжнародних логістичних систем[2]. 
Визначальну роль у становлення сучасної інтегральної концепції логістики відіграла можливість постійного контролю(моніторингу) над матеріальними потоками в реальному часі в режимах дистанційного доступу через інформаційні системи зв'язку( наприклад через супутникові телекомунікації) [1, С.18]. Це дало змогу використовувати зворотній зв'язок із споживачем як активний важіль маркетингової політики підприємств.

\section{Список використаних джерел:}

1.Балабанова Л.В. Логістика[Текст]: - Львів:Видавництво ПП «Магнолія 2006», 2015. - 368c.

2. Бауэрсокс Дональд Дж., Клосс Дейвид Дж. Логистика: интегрированная цепь поставок / Пер. с англ. - М.: ЗАО «Олимп Бизнес», - 2001.,- 640 с.

3. Gronroos C. Internal Marketing - Theory and Practice // T.M. Bloch (Ed) Services Marketing in Changed Environment. American Marketing Association, Chicago, 1985. - pp. 41-47.

4. Кальченко А.С. Логістика. - К.:КНЕУ, 2000. - 295с.

5. Кондратенко Н. О. Інструменти управління та методи оцінки ризиків у логістичних системах / Н. О. Кондратенко, О. О. Лобашов // Комунальне господарство міст: наук.-техн. зб. Серія "Економічні /науки". -2012. - Вип. 102. - С. 343-350.

6. Котлер Ф. Маркетинговий менеджмент / Ф. Котлер, К.Л. Келлер, А.Ф. Павленко та ін. - К.: Видавництво «Хім- джест», 2008. 720 c., c. 35.

7. Kotler P. Marketing 3.0: From Products to Customers to the Human Spirit / P. Kotler, H. Kartajaya, I. Setiawan. - Jonh Wiley \& Sonc. Inc., Hoboken, New Jersey, 2010. - 190p.

8. Панкрухина А.П. Маркетинг 3-е изд. - М.: Омега-Л, 2005. $656 \mathrm{c}$.

9. Решетнікова I. Маркетинг в прямих логістичних каналах: сучасні тенденції / І. Решетнікова // Маркетинг в Україні. - 2015. - № 1. - C. 46-52. - Режим доступу: http://nbuv.gov.ua/UJRN/Mvu_2015_1_7.

10. Світ до 2050 року: Deutsche Post DHL опублікувала футурологічне дослідження // Маркетинг в Україні. - 2012. - № 4. - С. 45-50. - Режим доступу: http://nbuv.gov.ua/UJRN/Mvu_2012_4_8. 
Kuzmenko V. M.,

Ph. D. student of Corporate Finance and Controlling department, SHEE «Kyiv National Economic University named after Vadym Hetman»

\section{FORMATION AND DEVELOPMENT OF INTERNATIONAL PROJECT FINANCE MARKET}

The process of financial globalization is accompanied by the use of a wide range of international investment forms in the current context. Project financing is one of these forms, which widespread use in the world has marked the international market formation.

The international project finance market, like any other market, consists of its development stages, infrastructure market units, supply that means financial resources, invested in the implementation of investment projects under terms of project financing, demand for these resources from investors and prices.

It is worth noting that the international project finance market (IPFM) development is cyclic process and still continues its duration nowadays. The cyclical development of the market is manifested on the background of economic, financial and global crises, which phases call for such development, corresponding to a certain period of the IPFM formation.

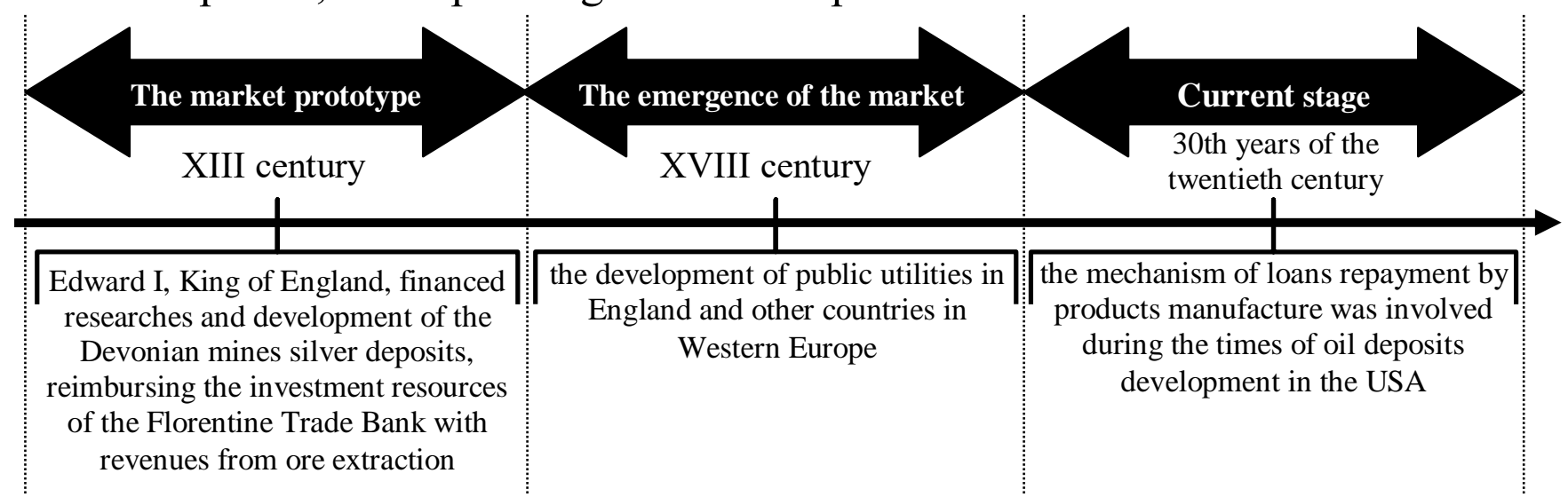

Figure 1. Stages of the international project finance market formation Source: compared by author on the basis of $[1,2]$.

IPFM has acquired its modern features only in the late 70th of the twentieth century. This was facilitated by this financing type spreading in large-scale foreign-trade transactions and the oil crisis of 1973, which led to a sharp increase in energy prices, significant investments in oil and gas extraction (oil reserves exploiting in the North Sea), the introduction of the energy efficiency regime and the energy supply companies' creation. In these circumstances, the world's leading banks, firstly, quickly began to 
accumulate petrodollars, which in turn led to a rapid increase of investment resources and their investment in oil and gas production. Secondly, these banks changed the vector of their activities, which was transformed from passive to active, namely the banks began to look for profitable projects for financing by themselves, assuming the increased risk.

Thereafter, financing by the project type served as a catalyst for energy and the raw materials industries development, namely: the development of deposits, the power plants construction, oil refineries etc. These industries and sectors faced the need for significant investment.

The energy and raw material projects had been the basis of a project finance portfolio formation in financial and credit institutions by the 1980th. However, the oil and gas prices decrease devalued the direction of banking activities and encouraged the development and expansion of project financing to other sectors and industries, including the high-tech industry, mining, tourist business and entertainment industry.

In 1982, the development of the project finance market was interrupted by the international debt crisis, which was initially accompanied by the rapid decline in volumes of lending under the sovereign guarantees of developing countries, and, subsequently, the complete termination of medium- and longterm lending by commercial banks to the balance sheets of these countries [2].

The significant improvements had taken place in 1989-1990, when Mexico, the Philippines, Venezuela and Costa Rica agreed to restructure external debt with their creditors in accordance with the "Brady Initiative" [3]. As a result, a number of countries initially received short-term loans, and then they received long-term loans for the investment projects implementation in accordance with project financing conditions.

The global financial crisis of 2008-2009, which was manifested as a result of rising inflation, currency imbalances increase, lending to the real sector of the economy and households reduce and the cost of credit rise, was not unaffected by the IPFM development. As a result, the existing lending capital has decreased. The largest infrastructure units, namely world's leading banks and developed countries governments were forced to suspend the new loans issuance in connection with decline in their return, to carry out absorption procedures, to declare themselves as bankrupt, to invest in distressed banks, to cancel the debts, to "put" capital into the banking sector in order to prevent the spread of the banking crisis.

In the present circumstances, in case of considering the project finance market by sectors of the economy, the energy sector ranks first, accounting for approximately $35 \%$ of the world market [4]. The infrastructure projects are at the second place that makes $27 \%$ of the world market. The oil and gas 
industry is at the third place, steadily losing its leading position in favor of mining since the late 80th. The mining industry is an appealing sector both for banks and transnational extractive corporations despite of barriers for similar projects implementation, including:

$>$ national governments measures to preserve and store resources in the form of strategic resources;

$>$ environmental friendliness and safety of the conducted activities;

$>$ high barriers to entry into the project (additional costs for licenses and permits, environmental monitoring, infrastructure creation);

$>$ long-term payback and construction.

It is also worth noting in the context of IPFM that the market evolution includes the evolution of its tools, principles, characteristics, models and schemes of project financing. Nowadays, bank loans, leasing, letters of credit, direct investment and commodity loans are the most widespread instruments, used by the international project finance market participants. In contrast, the least widespread instruments are international and regional financial and credit institutions, multilateral development agencies and investment support agencies, transnational and multinational corporations, large international insurance agencies, syndicates, governments, national export and import lending and insurance agencies, transnational banks, private lenders and institutional investors.

The existence of infrastructure units on the market always involves the presence of two opposing categories, namely demand and supply, which ratio determines the product price. The world's project finance market price has both specific and general characteristics, which are common for each market of loan capital:

Table 1

Characteristics of project finance price

\begin{tabular}{c|cc}
\hline \multicolumn{1}{c}{ Criterion } & Debt capital market & International project finance market \\
\hline Interest rate & Fixed and floating & Fixed, floating and differentiated \\
\hline Installation base & $\begin{array}{c}\text { Under the influence of supply } \\
\text { and demand }\end{array}$ & LIBOR rate \\
\hline Commission Fee & $\begin{array}{c}\text { It is charged for granting, } \\
\text { changing the terms of lending, } \\
\text { for servicing, for cash and } \\
\text { settlement services }\end{array}$ & $\begin{array}{c}\text { It is charged for the organization of financing, } \\
\text { management of the banking consortium, for agency } \\
\text { services in settlement and cash operations, for } \\
\text { guaranteeing the placement of debt, etc. }\end{array}$ \\
\hline Accessibility & $\begin{array}{c}\text { Determined by solvency of the } \\
\text { borrower }\end{array}$ & $\begin{array}{c}\text { The amount of funding is limited to either a certain } \\
\text { amount or a high interest rate }\end{array}$ \\
\hline Grace period & $\begin{array}{c}\text { Present in some cases } \\
\text { (loans for investment purposes) }\end{array}$ & $\begin{array}{c}\text { Distributed to the main part of the debt and } \\
\text { sometimes on interest (concession). Exemption of } \\
\text { borrower from payment of obligations until the } \\
\text { moment, when the investment object starts to } \\
\text { generate revenues }\end{array}$ \\
\hline
\end{tabular}


Source: compared by author

The IPFM characteristics, structured in accordance with regional principles, are selected in consideration with the regional peculiarities of the projects implementation and the worldwide allocation of the market infrastructure units and represented in Table 2.

Table 2

Features of the project finance market by region

\begin{tabular}{l|l}
\hline & The least contribution of loan capital in project financing. \\
& The use of a special project financing scheme that focuses on derivative financial \\
resources and instruments. & Projects "advertising". \\
\hline & The local banks loans are largely common for projects \\
& The countries of the region are highly dependent. \\
A clear division of banks into participants, participants' universals and aggressive \\
speculators, whose functions within project finance organization are different. \\
Insufficient flexibility of European banks.
\end{tabular}

Source: compared by author on the basis of [5, p. 149]

Taken together, the IPFM has its own history of development, which proved the practical effectiveness and reliability of project financing. Thus, nowadays, project financing is one of the most widespread forms of attracting and investing in the real sector of the economy in both industrialized and new industrialized developing countries due to the international market formation and provision of the opportunity for active engagement of the real sector of the economy with financial and banking sector.

\section{References:}

1. Kesinger, John V. Project Finance: Raising Money the Old-Fashioned Way / John V. Kesinger, John D. Martin // New Corporate Finance: Theory is Confirmed by Practice. New York: McGraw-Hill. - 1999. $326 \mathrm{p}$. 
2. Katasonov, V. Yu. Project Financing: World Experience and Perspectives for Russia / V. Yu. Katasonov, D. S. Morozov, M. V. Petrov. - 3rd ed., Pererab. and add - M .: Ankil. - 2001. - 308 p.

3. Debt relief logic for the poorest countries. - [Electronic resource]. Access mode: https:/www.imf.org/external/np/exr/ib/2000/rus/092300r.htm

4. Global Infrastructure Finance Review. - [Electronic resource]. Access mode: http://www.ijonline.com

5. Filippova, L.E. World project finance expertise. The role of banks. [Electronic resource]. - Access mode: http://elib.bsu.by/bitstream/123456789/5402/1/filippova_2011_8_IE $\mathrm{R}$ issues.pdf

Куліш Л. П., Київський національний торговельно-економічний університет

\section{ДЕРЖАВНА ПОЛІТИКА ПІДВИЩЕННЯ КОНКУРЕНТОСПРОМОЖНОСТІ НАЦІОНАЛЬНОЇ ЕКОНОМІКИ}

Конкурентоспроможність національної економіки грунтується на цілій низці макроекономічних, нормативно-правових та організаційноінституційних умов, які дають змогу економічній системі балансувати у координатах внутрішніх та зовнішніх ризиків, адаптуватися до них та вийти на траєкторію стійкого розвитку після їх прояву. Для протидії негативним зовнішнім факторам та зменшення несприятливих наслідків виділяють такі цілі та завдання державної політики у сфері забезпечення конкурентоспроможності національної економіки, як макроекономічна стабільність, ефективність внутрішнього ринку та державного управління, стійкий соціальний розвиток.

Вагомим орієнтиром розвитку української економіки $\epsilon$ формування ефективної конкурентоспроможної економіки, здатної забезпечити стійке економічне зростання і високий рівень життя населення. При цьому необхідно стимулювати конкурентне середовище як підгрунтя для розвитку підприємництва, підвищення ефективності функціонування економіки та зростання іiї потенціалу. На основі проведеного аналізу можна дійти висновку про те, що за умов 
розгортання глобалізаційних процесів держава покликана забезпечувати конкурентоспроможність національної економіки, а для цього їй слід сформувати ефективну політику, яка сприятиме вітчизняним підприємствам у їх високотехнологічному експорті та прагнутиме підвищувати конкурентоспроможність товарів українських виробників порівняно з їхніми імпортними аналогами $[1$, c. 35-39].

Аналіз світового досвіду дає змогу дійти висновку про те, що досягнення конкурентоспроможності національної економіки неможливе без активної цілеспрямованої політики держави. На основі сподівань лише на регулювальну роль ринкових механізмів неможливо розв'язати проблеми розвитку суспільства, а тому докорінної модернізації потребує політика стимулювання конкурентоспроможності національних суб'єктів господарювання [2].

На сучасному етапі розвитку світового господарства особливу роль у досягненні стійкої конкурентоспроможності економіки будьякої країни відіграють інновації. Перехід до інноваційної моделі розвитку, зростання впливу інноваційної складової на ефективність і конкурентоспроможність економіки ставлять проблеми прискореної розробки та впровадження інновацій у ряд пріоритетних.

Особливого значення набуває діяльність інноваційного підприємництва як найбільш гнучкої складової економіки країни. Однак в силу специфіки своєї діяльності інноваційне підприємництво потребує державної підтримки. Вагомі інноваційно-інвестиційні програми повинні орієнтуватися на вирішення завдань структурної трансформації національного господарського комплексу. При цьому йдеться про створення високотехнологічних підприємств, виробництво в яких базуватиметься на найсучасніших технологіях, розвиток сучасної інфраструктури для ефективного функціонування внутрішнього ринку, оновлення матеріальної бази галузей соціальної сфери [3, с. 7-11].

Активна державна політика здатна створити передумови для підвищення національної конкурентоспроможності. Вихід української економіки на траєкторію стійкого економічного зростання можливий лише у разі комбінації інституціональних і структурних перетворень, а також сучасної промислової та конкурентної політики. Інструментарій і методика економічної політики держави мають змінюватися в міру реалізації інституціональних і структурних реформ.

Водночас, якщо економіка перебуває в рецесії, це не сприяє швидкості здійснення інституціональних трансформацій. Слабкі інститути, у свою чергу, зменшують шанси на успіх державного 
регулювання, тому що важливі рішення не завжди ухвалюються в інтересах країни. Одне 3 найголовніших завдань державного регулювання полягає у формуванні довіри і співробітництва між державою та підприємницьким сектором, на основі чого можна закласти основу для успішного проведення інституціональних перетворень. Слід одночасно реалізувати інституціональні й структурні реформи, з одного боку, а також здійснювати промислову та конкурентну політику - 3 іншого [4, с. 5-12].

При цьому структурно-функціональна модель системи оцінки ефективності державної політики підвищення конкурентоспроможності має бути побудована на засадах конкретизації індивідуальних завдань кожного суб'єкта окремо у межах чинного законодавства, спрямованих на поліпшення економічних i соціальних відносин між усіма суб'єктами та підвищення ефективності національної економіки у цілому. Для України використання потенціалу ендогенного розвитку як найефективнішого шляху виходу з економічної кризи, зростання ролі держави в економіці, стимулювання інвестицій в інноваційну сферу, сприяння розвитку економіки знань, підвищення мотивації праці та підприємництва мають слугувати основними векторами нової парадигми конкурентоспроможності [5, с. 4-10].

У цьому контексті розв'язання завдань підвищення конкурентоспроможності української економіки визначатимуть вектор розвитку країни протягом тривалого періоду. Вкрай необхідно не тільки визначити пріоритети національної конкурентоспроможності, але й наполегливо реалізовувати їх, підвищуючи ефективність державної політики. Реалізація завдань національного розвитку, економічного зростання, підвищення конкурентоспроможності національної економіки потребують активізації ролі держави у цих процесах. Для цього потрібна активна державна політика та розвиток ефективного підприємництва.

\section{Список використаних джерел}

1. Вертелєва О. Фактори міжнародної конкурентоспроможності України / О. Вертелєва // Вісник Київського національного торговельно-економічного університету. - 2016. - №3. - C. 33-48

2. Пустовойт О. В. Інституційна природа економічних циклів. Досвід України / О. В. Пустовойт. - К.: Ін-т екон. та прогнозув., 2016. -388 c. 
3. Романенко В. Конкурентна політика та конкурентоспроможність національної економіки / В. Романенко // Вісник Київського національного торговельно-економічного університету. - 2016. - №3. - С. 5-16.

4. Геєць В. М. Ендогенізація розвитку економіки у вимірі рівноправності відносин держави, бізнесу та суб'єктів голосування / В. М. Геєць // Економіка України. - 2018. - №7. - С. 3-19

5. Лагутін В. Економічна політика держави та ефекти їі реалізації

/ В. Лагутін // Вісник Київського національного торговельноекономічного університету. - 2017. - №4. - С. 5-21

Малий І.Й. доктор економічних наук, професор, Київський національний університет імені Вадима Гетьмана

\section{КОНВЕРСІЯ ПУБЛІЧНОГО УПРАВЛІННЯ ЕКОНОМІКОЮ В УКРАÏHI}

Сучасна криза цивілізаційного прогресу та суспільних наук висуває на порядок денний проблему формування нового економічного порядку нових ідей та системи поглядів на взаємодію громадянина та держави, національного та глобального, публічної економіки та приватної економіки в управлінні суспільством [1]. До сучасних тенденцій розвитку цивілізації необхідно також віднести й органічну взаємозалежність та взаємообумовленість між собою розвитку всіх сфер людської діяльності (економічної, соціальної, політичної, гуманітарної і т.п.), що потребує використання принципів міждисциплінарного (екуменічного) підходу та верифікації [2]. А використання методології інституціоналізму дозволяє розкрити сутність та специфіку публічного управління економікою України, яка понад чверть століття перебуває в стані перманентних змін [3].

Організація державою господарської системи фактично полягає в розбудові системи економічних інститутів. Склад економічних інститутів за кожним функціональним напрямом змінюється, адже постійно виникають нові функціі. Водночас у кожному 3 таких напрямів функціонують базові економічні інститути. Досягнення єдності, узгодженості економічних інститутів у межах як функціональних напрямів, так і господарської системи, є головним 
завданням держави щодо забезпечення ії цілісності. Але з точки зору результативності управління публічною економікою ми отримали низку інституційних деформацій (тіньова економіка, олігархічна монополізація, корупція в розподілі та привласненні національного багатства та публічних фінансів), які з середини дискредитують базові інститути державності та підривають довіру до них з боку громадян. В публічному управлінні економікою України відбувається нашарування старих i нових інститутів (правил) в управлінні економікою, їх конверсія, суспільне усвідомлення яких відстає в часі та просторі [4 ]. Як в економіці, так і в публічному управлінні ми отримали в Україні гібридні, інколи навіть деструктивні, організаційно-економічні форми та методи, що й означає їх конверсію. Замість малого та середнього бізнесу ми сформували олігархічну систему економіки та управління державою, замість конкуренції -монополізацію, замість середнього класу (медіанного виборця) - «публічну» владу олігархів з тотальною корупцією всього суспільства, замість добробуту - злиденність та катастрофічне соціальне розшарування населення, замість економічного зростання національної економіки - руйнацію виробничої та соціальної інфраструктури; нищівну експлуатацію природних та людських ресурсів. Держава як організаційнй центр має верховенство в господарський системі, що виявляється в добровільній чи примусовій підпорядкованості суб'єктів усіх рівнів економічному центру, в ієрархічному характері зв'язків економічних суб'єктів з ним та має панівне становище стосовно до кожної підсистеми суспільства [5]

Застосування принципу верифікації до оцінювання державного управління в Україні дозволяє зробити висновок про наукову невизначеність цілей та способів їх досягнення в реальному вимірі українського державотворення. Так, зокрема тотальна приватизація суперечить формуванню інститутів державності Україні, фінансовоекономічною базою розвитку яких $\epsilon$ функціонування державного сектору економіки. Пошук нових методів та інструментів публічного управління складає головне завдання кожного суспільства на шляху досягнення добробуту. На сьогодні публічне управління, як свідчить досвід Нової Зеландії, Австралії та Сінгапуру, перебуває в стані постійного реформування. В розвинених країнах поступово здійснюється перехід від бюрократичної моделі публічного управління (Public Administration) до менеджерської моделі (Public Management), a в окремих країнах запроваджуються елементи координаційної моделі 
(Public Governance). Модернізація публічного управління набуває в розвинених країнах людиноцентричного тренду.

3 моменту отримання незалежності перед українським суспільством постала найважливіша проблема - проблема ефективності функціонування держави. Сьогодні досить багато праць присвячено ролі і місцю публічного управлінню в суспільстві, його суспільним функціям, тоді як на перший план висувається проблема здатності держави взагалі виконувати будь-які функції, не кажучи про стратегію забезпечення конкурентноздатності національної економіки України на світовому ринку. 3 точки зору створення та надання суспільних благ, держава в Україні постійно деградує. Теорія суспільного вибору (Д.Бюккенен, Г.Таллок), теорія колективних дій (М.Олсон), інституційна теорія держави (Д.Норт) акцентують увагу на функціонуванні держави як організації, яка повинна надати громадянам суспільні послуги, забезпечувати справедливість та безпеку життєдіяльності людей. Стабільність в суспільстві може бути досягнуто шляхом рівноважного балансування між ринком (ефективністю) та державою (справедливістю).

Існування в суспільстві формальних (публічних) правил, які тільки продукуються в пресі та інших засобах інформації з одного боку, і неформальних правил, на які повинні зважати всі суб'єкти господарювання у своїй діяльності - 3 другого, складає методологічну засаду формування інституційних пасток у взаємодії держави та бізнесу. Такий стан спричиняє високий рівень невизначеності, дуалізм норм, персоналізацію економічних i, особливо, фінансових відносин, виникнення різного роду інституційних пасток. Прагнучи стійкості в суспільстві, держава має спиратися на соціальні цінності та виробляти життєві стандарти, які вкоренившись у суспільстві, роблять іiі соціально міцним, конкурентоспроможним та стабільним інститутом, діяльність якого сприятиме не тільки збереженню та примноженню населення України, а й досягнення їх високого рівня добробуту, а значить й підвищенню довіри до держави та ствердження державності.

\section{Список використаних джерел}

1. Стиглиц Дж.Е. Крутое пике: Америка и новый экономический порядок после глобального кризиса / Стиглиц Джозеф;(пер.с англ. В.Лопатка).- М.: Эксмо, 2011. - 512c

2. Малий І.Й.,Диба М.І., Галабурда М.К. „ Держава і ринок: філософія взаємодії: Монографія / За заг. та наук.ред д-ра екон. наук, проф.. І.Й. Малого. - К.:КНЕУ, 2005. - 358c 
3. Антикризове управління національною економікою : монографія / [ І.Малий, І.Радіонова, Л.Смельяненко та ін. ] / за заг.ред. I.Малого.- К.:КНЕУ, 2017.- 368

4. Streeck W. Beyond continuity: Institutional change in advanced political economies / W.Streeck, K.Thelen.-Oxford: Oxford University press, 2005

5. Малий І.Й. Нове державне управління економікою в умовах глобалізаційних та інституційних змін / І.Й. Малии // Научные труды ДонНТУ. Серия: экономическая. Вып. № 2 (44). - Донецк: ДонНТУ, 2013 - С. $38-42$.

Міняйло O.I., к.е.н., доцент Міняйло В.П., к.е.н.

Київський національний торговельно-економічний університет

\section{СТИМУЛЮВАННЯ РОЗВИТКУ МАЛОГО ПІДПРИСМНИЦТВА В УКРАЇНІ: ФІСКАЛЬНИЙ АСПЕКТ}

Розвиток малого підприємництва для України, виходячи 3 окремих положень Стратегії сталого розвитку «Україна - 2020», $\epsilon$ одним 3 найактуальніших завдань для органів виконавчої влади всіх рівнів. Прискорення темпів економічного зростання, ліквідація дисбалансу в розвитку територій, боротьба з бідністю, розвиток інновацій, стимулювання розвитку нових малих підприємств, підвищення їх конкурентоспроможності та збільшення зайнятості працівників має стати пріоритетним завданням у цій сфері.

Податкове регулювання ринкових відносин $є$ невід'ємною складовою фінансового регулювання в будь-якій країні 3 ринковою економікою. В ході формування та реалізації податкової політики держава застосовує як стимулюючі, так і стримуючі методи впливу на діяльність економічних суб'єктів. Проблема фіскального регулювання малого підприємництва досить гостро стоїть на даному етапі економічного розвитку України. Необхідно визначити оптимальний ступінь державного втручання у підприємницьку діяльність 3 метою забезпечення ефективного функціонування приватного сектора економіки, а з іншого - створити передумови для збалансованого росту економіки країни загалом та підвищення рівня добробуту громадян. 
Сучасний стан малого підприємництва в Україні свідчить про необхідність стимулювання його розвитку з боку держави, а отже $\mathrm{i}$ продовження дії спрощеної системи оподаткування. Незважаючи на всі недоліки та аргументи проти спрощеної системи оподаткування, іiі ліквідація не є ефективним рішенням, адже вона має важливе соціальне значення в нашій країні. Також необхідно враховувати, що скасування спрощеної системи несе ризик переходу в «тінь» значної кількості суб'єктів малого підприємництва, що, як наслідок, призведе до зниження рівня розвитку малого бізнесу та зменшення податкових надходжень від єдиного податку до бюджету. Спрощена система оподаткування $\epsilon$ способом так званої «компромісної детінізації»: завдяки наявності такої системи офіційна реєстрація стає відносно більш привабливою, порівняно з роботою у цілковитій «тіні», оскільки забезпечує легальність та мінімальний правовий захист, не вимагаючи при цьому ведення обліку та дозволяючи сплачувати помірні податки [3].

Створення системи податкового стимулювання передбачає узгодженість всіх вказаних елементів на основі сформульованих вимог та правил застосування. На рисунку відображено вплив стимулів на розвиток суб'єктів малого підприємництва і державу. 


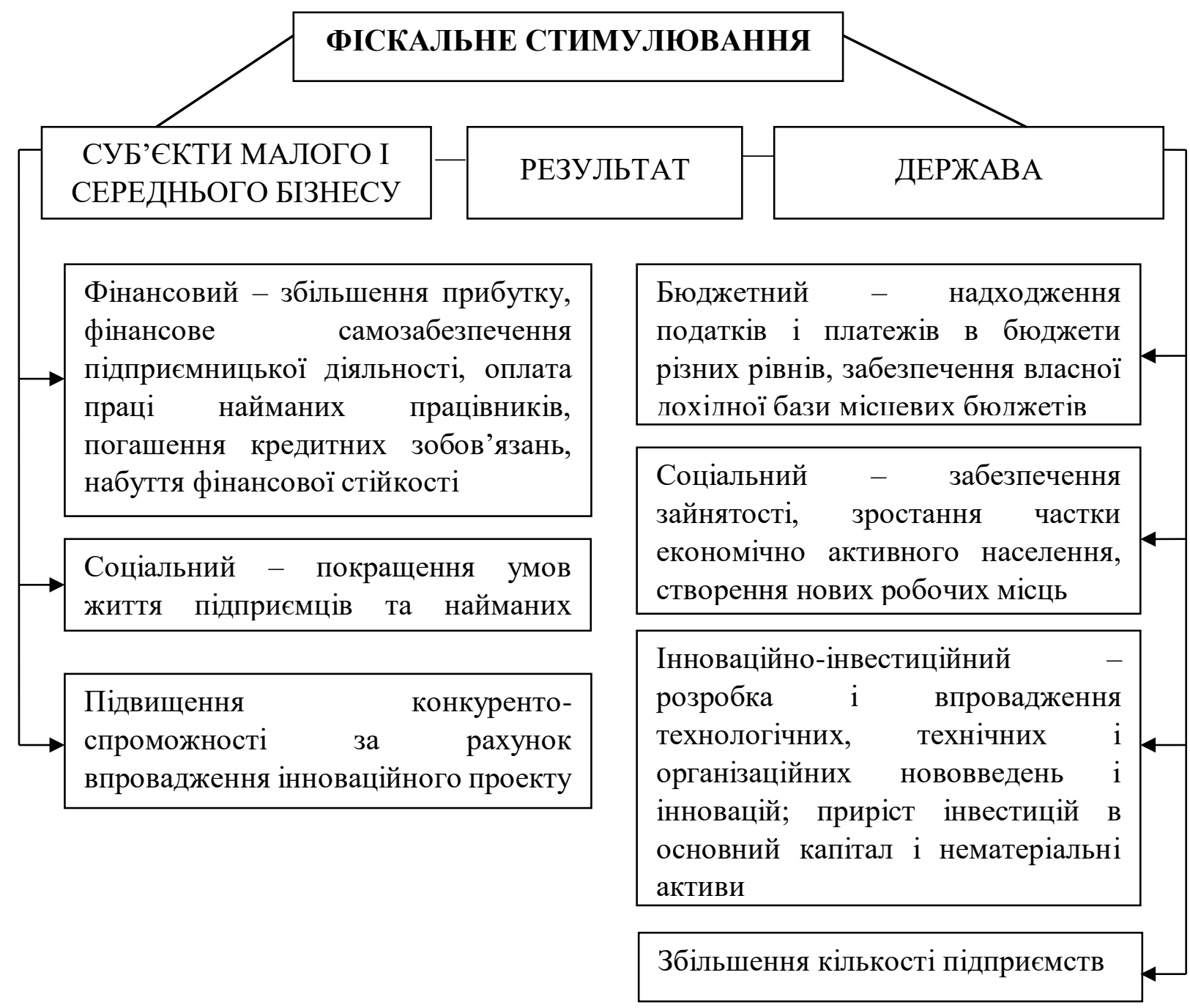

\section{Рис. Ефекти впливу фіскальних стимулів на розвиток суб'сктів малого підприємництва і держави}

Основними кроками держави на шляху підтримки розвитку малого бізнесу в світовій практиці вважають:

- створення раціональної нормативно-правової бази;

- вдосконалення спрощеної системи бухгалтерського обліку та звітності малих підприємств;

- організація фінансової підтримки малого бізнесу [1, С. 57].

Підприємства, які обирають «шлях оподаткування» за спрощеною системою, здійснюють свою діяльність та сплачують єдиний податок, який у стовідсотковому об'ємі зараховується до місцевих бюджетів і $є$ основою наповнення бюджету розвитку. У 2018 p. надходження єдиного податку від суб'єктів малого підприємництва становили 7,4 млрд. грн., що на 11,6\% більше за обсяги надходжень 2017 р. Статистичні дані підтверджують, що обсяги надходжень єдиного податку починаючи з 2016 р. зростають більш ніж у два рази. 
Так, у 2016 р. сума надходжень склала 4 815,6 млн. грн., що на 242,2\% більше, ніж у 2015 р. Така динаміка зростання спостерігається протягом 2017 та 2018 рр. [2, 4].

Слід зазначити, що наявність спрощеної системи оподаткування, як один 3 методів стимулювання розвитку малого підприємництва, сприяє позитивній динаміці щодо нарощування обсягів реалізованої продукції. Так, за останні роки спостерігається збільшення обсягів виробництва з 568267,1 тис. грн. у 2014 р. до 705000,5 тис. грн. у 2018 p., що необмінно позначається на зростанні податкових відрахувань та поповнення державного та місцевих бюджетів [4].

Статистика свідчить, що за останні роки кількість малих підприємств в Україні коливалась від 357241 у 2014 р. до 324598 у 2018 p. [4]. Це можна пояснити політичною та економічною нестабільністю, змінами в податковому законодавстві та пристосуванням до нової системи оподаткування (прийняття нового Податкового кодексу у 2018 p.). Виконуючи свою соціальну функцію, малий бізнес країни сьогодні охопив майже 1686,9 тис. українців, які щомісяця сплачують податки, тим самим забезпечуючи наповнення бюджету.

Що стосується оподаткування, то на сьогодні найбільш дієвим у плані стимулювання й розвитку малого бізнесу 3 погляду оптимального оподатковування є єдиний податок. Спрощена система оподатковування в Україні застосовується вже майже 18 років, i практичний досвід іiї використання дає підстави для того, щоб говорити про безсумнівний позитивний вплив, зокрема, стимуляцію режиму оподатковування на сектор малого бізнесу, його поступове розширення та ефективність для держави.

Одним із позитивних моментів спрощеної системи оподатковування $є$ те, що вона дає можливість суб'єктам малого бізнесу забезпечити роботою не тільки себе, але й інших громадян, створюючи додаткові робочі місця. Ефективність спрощених режимів оподатковування також підтверджується щорічним збільшенням платежів у бюджет, що становлять у 2014 р. в сумі 7,4 млрд. грн., що на 11,6\% більше за обсяги надходжень у 2013 р. [2, С. 52-53].

Необхідно додати, що спрощена система оподаткування протягом останніх років пережила декілька хвиль найбільш істотних змін. Постійний перегляд обмежень для малого бізнесу, змін правил перебування на спрощеній системі оподаткування сприяли важкості ведення бізнесу i, як наслідок, потребували від підприємців більше часу для адміністрування, зміни тактики ведення бізнесу та зважування власних ризиків і переваг. Зростаюча роль малого бізнесу в економіці заставила більшість країн СС визнати необхідність 
розробки спеціальної податкової політики, яка заслуговує особливої уваги для вітчизняної моделі оподаткування малого підприємництва.

Оподаткування малого бізнесу в Україні зазнало чимало структурних й інституційних змін 3 моменту його впровадження. Однак і на сучасному етапі соціально-економічного розвитку однією 3 нагальних проблем й водночас однією 3 стратегічних цілей реформування української економіки $\epsilon$ подальше формування й зміцнення потенціалу розвитку малого підприємництва в України.

\section{Список використаних джерел}

1. Волкова Н.І. Аналіз проблем кредитування малого та середнього бізнесу в сучасних економічних умовах / Н.І. Волкова, К.Д. Свірідова // Фінанси, облік, банки. - №1. - 2017. - С.55-62.

2. Губенко В.В. Бюджетний моніторинг: Аналіз виконання бюджету за 2018 р. / В.В. Губенко, І.В. Самчинська, А.Ю. Рудик та [ін.]; ІБСЕД, Проект «Зміцнення місцевої фінансової ініціативи (ЗМФІ - II) впровадження», USAID - K., 2019. - 77 с.

3. Дубровський В., Черкашин В. Порівняльний аналіз фіскального ефекту від застосування інструментів ухилення/уникнення оподаткування в Україні [Електронний ресурс] // Інститут соціальноекономічної трансформації. - Режим доступу: https://rpr.org.ua/wpcontent/uploads/2018/02/Instrumenty-uhylyannya-vid-splaty-podatkiv2017-1.pdf.

4. Офіційний сайт Державної служби статистики України [Електронний ресурс]. - Режим доступу: http://www.ukrstat.gov.ua.

Павлішина H.M., к.е.н., Національний університет «Запорізька політехніка»

\section{АДАПТАЦІЯ ЛОГІСТИЧНИХ ПРОЦЕСІВ ДО ЕЛЕКТРОННОЇ ФОРМИ ТОРГІВЛІ}

Розвиток Інтернету, широкі можливості, що надає мережа прискорили еволюцію бізнес-процесів, та призвели формування електронного ринку який дав початок розвитку електронної комерції. Науковці та практики відмічають, що це подія, яка формуватиме економіку нового тисячоліття.

За даними Інтернет Асоціація України (ІнАУ), яка раз на квартал проводить дослідження рівня проникнення Інтернет у суспільство, цей 
показник станом на лютий 2019 р. складає 64\%. Тобто, дві третини населення України мають постійний доступ до мережі та користуються нею для задоволення своїх потреб [1].

Можливості, що їх надає Інтернет, оцінили як користувачі, так i представники бізнес-середовища. За даними компаній AG Marketing (аналітика та просування у Інтернет) [2] та української продуктової ITкомпанії EVO [3] ринок E-commerce у цифрах виглядає наступним чином:

- товарообіг - 50 млрд.грн. Прогнозоване зростання на наступний рік - до 65 млрд.грн. Зауважимо, що світовий товарообіг - 2,8 трлн.дол;

- найбільш крупна група площадок в сегменті онлайн-торгівлі Prom.ua, Bigl.ua, Crafta.ua, Shafa.ua (проекти компанії EVO). На них витрачено 14,2 млрд.грн. Що на 70\% більше ніж роком раніше;

- сегмент електронной торгівлі - 4\% від загального ринку роздрібної торгівлі України. Через це аналітики зазначають, що має місце не стільки конкуренція між продавцями, скільки консолідація зусиль та досвіду спрямована на збільшення ринку онлайн-торгівлі;

- витрати на транспортування товару складають 4\% від товарообігу.

Запорукою ефективності електронної торгівлі $є$ постійна наявність товару, зручна оплата, доставка та повернення товару, персоналізований сервіс. Тобто, незважаючи на широкі можливості, що відкриваються електронною комерцією, $є$ деакі торгівельні операції, реалізація яких об'єктивно неможлива без традиційної (офлайн) взаємодії. Найбільш важливою формою взаємодії $\epsilon$ поєднання електронної торгівлі та логістичних процесів, тобто розвиток електронної логістики.

Е-логістика, за визначенням Н. Чухрай та О. Гірної - це «ефективне управління інформацією та співпраця усіх учасників ланцюга на підставі швидкого i докладного передавання інформаційного потоку з пунктів роздрібної торгівлі, які пересилають дані в узгодженому інформаційному стандарті до постачальника виробника вихідної сировини» [4, с.273].

Оскільки тенденція зростання у сфері онлайн-торгівлі буде зберігатись і в майбутньому, а прогнозування розвитку компаній в окремих галузях на даний момент ускладнене, багатьом торговим компаніям i центрам дистрибуції доводиться заново створювати структуру логістики або постійно адаптувати їі.

Сьогодні компанії, що ведуть діяльність на ринку E-commerce стикають с численними викликами у сфері логістики:

- необхідність орієнтуватися на високі швидкості постачання; 
- необхідність постійного скорочення строків доставки;

- коливання рівня замовлень у залежності від сезону, наявності святкових дат і навіть дня тижня;

- виникнення термінових замовлень;

- значна кількість повернення товарів.

В.Іжевська виділяє три форми постачання товару до клієнта:

- пряме постачання споживачеві у встановлене місце (місце проживання, роботи і т. д.) і час. Постачання при цьому здійснюється повністю під відповідальністю продавця;

- непряме постачання споживачеві через bох-систему, яка знаходиться у зазначеному споживачем місці. Така система розширює час поставки і дозволяє раціоналізувати транспортні потоки;

- приймання товарів споживачем у встановленому місці. Таке місце називають місцем прийняття вантажів (pick-up-points). В цьому випадку частково або повністю відповідальність за транспортування лягає на покупця [5, с. 167].

Однак, постачання товару - це лише верхівка логістичного айсбергу. У рішеннях для організації складської діяльності та дистрибуції сьогодні часто мають також враховуватись вимоги, притаманні сфері онлайн-торгівлі. При цьому торгівля через інтернет відрізняється від звичайної логістики, зокрема, у кілька разів вищою оборотністю, а також необхідністю обробки збільшеної частки повернень, яка часто здійснюється в автоматичному режимі.

Серед переваг Е-логістики Н.Т. Гринів називає:

- значне скорочення витрат, за рахунок заміни фізичних площ на дисковий простір;

- можливість вийти у міжнародний простір;

- можливість збільшити розміри партій за рахунок укладання довгострокових експортних договорів на поставку. Товар збирається у дрібних товаровиробників через інформаційну систему;

- скорочення часу виходу на ринок і зміни асортименту;

- мінімізація нереалізованих запасів [6, с. 577].

Bce це висуває вимогу до організації та використання максимально гнучких, простих і швидких логістичних процесів, які дозволяють реагувати на швидкозмінні запити споживачів. При цьому значна частина витрат інтернет-магазинів - це логістика та просування. Конкуренція стимулює до економії, зокрема до мінімізації витрат на логістику. А отже, вибір форми організації логістичного процессу $є$ важливим рішенням, що визначає ефективність роботи на ринку.

Перед операторами електронного ринку постає питання виконувати логістичні функції самостійно чи віддати логістику на 
аутсорсинг. Логістичне управління, що здійснюється самостійно є більш привабливим варіантом через можливість повного контролю та отримання прибутку. Однак, через дороговизну більшість компаній передає логістичний процесс (повністью або частково) у аутсорсинг. Послуга $з$ повної передачі сьогодні відома під назвою «fulfillment services». 3 англійської термін не має точного перекладу, тому він використовується без перекладу як «фулфілмент».

Фулфілмент, як спосіб побудови логістичного процессу, окрім традиційного управління товарними потоками включає значний обсяг послуг інформаційної логістики і інших послуг: складське зберігання товарів, прийом та обробка замовлень, прийом платежів, комплектація та упаковка замовлень, доставка, організація сервісів підтримки та послуг call-центрів, робота 3 поверненнями [7, с. 23]. Фулфілмент надається зазвичай 3PL - провайдерами (Third Party Logistics Provider).

Серед інших аспектів, що дозволяють адаптувати логістику до електроної форми торгівлі можна виділити:

- розширення способів доставки. Сьогодні це лише поштомати, УкрПошта, експрес-доставка;

- оптимізація логістики доставки замовлень і повернень;

- передача всіх логістичних функцій одному партнеру. Так званий «fulfillment+»;

- впровадження IT-технологій;

- підвищення рівня інформаційного сервісу завдяки акцентуванні уваги на мобільних додатках;

- максимізація зворотнього ROPO («research offline, purchase online» - досліджуй офлайн, купуй онлайн);

- масимальне прискорення та здешевлення доставки;

- вихід на міжнародні ринки;

- відмова від паперового документообігу тощо.

Резюмуючи можна відмітити, що поява Е-логістики це лише початок масшабно адаптації логістичних процесів до вимог сучасного електронного ринку. Сьогодні ми можемо спостерігати зміни логістики у бік сталого та якісного розвитку, забезпечення прозорості бізнес-процесів. Це дозволить реалізувати значний потенціал українського ринку електронної торгівлі та підвищити конкурентоспроможність вітчизняних підприємств на міжнародному ринку 


\section{Список використаних джерел}

1. Дослідження інтернет-аудиторії [Електронний ресурс] // Інтернет Асоціація України (ІнАУ). - Режим доступу: https://inau.ua/proekty/doslidzhennya-internet-audytoriyi

2. Электронная коммерция в Украине 2018: цифры, факты, интересная статистика [Електронний ресурс] // AG.MARKETING. Режим доступу: https://ag.marketing/uk-ru/elektronnaya-kommertsiya-vukraine-2018/

3. Итоги и планы: e-commerce Украины 2018/2019 [Електронний pecypc] // EVO. - Режим доступу: https://evo.business/itogi-plany-ecommerce-ukrainy-20182019/

4. Чухрай Н.I. Розвиток логістики в умовах Е-економіки // Логістика: [збірник наукових праць] / відповідальний редактор Є.В. Крикавський. - Львів: Видавництво Національного університету «Львівська політехніка», 2008. - 340 с. - (Вісник Національного університету «Львівська політехніка» ; № 623). - С. 272-278

5. Іжевська В. Електронна торгівля (е-логістика) // 69-та студентська науково-технічна конференція: секція «Економіка i менеджмент» : збірник тез доповідей / Національний університет «Львівська політехніка». - Львів : Видавництво Львівської політехніки, 2011. - С. 166-168.

6. Гринів Н.Т. Логістика електронної торгівлі в Україні // Вісн. Нац. ун-ту «Львів. політехніка». - 2010. - № 690. - С. 576-579.

7. Винокурова П. Логистика для E-commerce [Електронний peсурс - Режим доступу: http://www.logistikaprim.ru/sites/default/files/22-24_1.pdf.

Петренко Н.В. Київський національний торговельно-економічний університет

\section{ПРІОРИТЕТНІ НАПРЯМИ ПРОТИДІЇ СИСТЕМНІЙ КОРУПЦЇ̈ В УКРАЇ̈I}

Однією з найгостріших та найактуальніших проблем сьогодення нашої держави, що гальмує ii розвиток та стримує економічне процвітання $\epsilon$ корупція. Тому одним 3 пріоритетних напрямків для нашої держави $є$ розробка ефективної системи протидії цьому явищу. Економічна доцільність протидії корупції передбачає, що 
антикорупційні заходи повинні бути економічно обгрунтованими як 3 точки зору їхньої економічної ефективності, так і можливих негативних побічних наслідків, а також реальної економічної можливості їх впровадження в життя.

Виділяємо наступні заходи протидії корупції, використання яких дозволить змінити систему стимулів та сприятиме іiі протидії: спостереження за поведінкою, службовими контактами державних службовців; періодичне вивчення документів щодо діяльності державного службовця за певний період; визначення кола посадових осіб та громадян, з якими державний службовець 3 корисливих мотивів контактує в процесі роботи, встановлення осіб, з якими такі контакти здійснюються систематично; проведення планових перевірок діяльності державного службовця, оцінка законності та обгрунтованості його дій.

Антикорупційна реформа в Україні потребує системного підходу. Відтак першим кроком стало затвердження Верховною Радою України Закону - нової антикорупційної стратегії [1], що на нашу думку дозволило в цей період часу комплексно підійти до вирішення проблеми, визначити чіткі цілі та часові рамки і засоби їх досягнення, а також поєднати антикорупційні реформи з іншими, зокрема такими як судова реформа, реформа органів правопорядку, державної служби, адміністративна реформа тощо.

Стратегія сталого розвитку «Україна - 2020», передбачає оновлення влади та антикорупційну реформу метою якої є зниження рівня корупції в Україні, зменшення витрат державного бюджету та бізнесу через корупційну діяльність, а також підвищення позицій України у міжнародних рейтингах, що оцінюють рівень корупції [6].

Чинниками вдалої та результативної антикорупційної реформи, які апробовані міжнародною спільнотою є: насамперед чітко визначені алгоритми дій та норми етичної поведінки державних службовців усіх рівнів; закріплена законодавчими нормами відповідальність за недотримання їх; прозорість діяльності влади, відкритість процедури прийняття нею державних рішень; активність громадянського суспільства, що проявляється в безперервному контролю діяльності посадових осіб з висвітленням іiі результатів у незалежних засобах масової інформації.

Пріоритетні напрямки антикорупційної реформи та способи їх досягнення є наступні:

1. Реформування органів державної влади, оптимізація та конкретизація їх повноважень, посилення доброчесності та 
підзвітності шляхом скасування служб підвищеного корупційного ризику, передача їх завдань новоствореним інституціям.

2. Реформа виборчих технологій шляхом недопущення корумпованих чиновників до керівних посад.

3. Удосконалення механізму забезпечення прозорості державної економічної політики шляхом надання громадськості можливості контролю дій уряду, зміцнення міжнародного співробітництва по протидії корупції.

4. Реформа судової системи і правоохоронних органів шляхом завершення люстрації шляхом публічності; встановлення громадського контролю за суддями; запровадження права місцевих громад на законодавчому рівні відкликати суддю у будь-який час та їх судове переслідування за вчинення неправомірних дій; забезпечення відкритості питань, що вирішуються.

5. Реформа податкової системи шляхом забезпечення уникнення спеціальних привілеїв та пільг, що ставлять галузі в нерівні умови; включення лише мінімально необхідних податків та зменшення винятків та спеціальних режимів, з чіткими та зрозумілими правилами; застосування ставок, що базуються на об'єктивній платоспроможності платників.

6. Митна реформа

шляхом лібералізації зовнішньоекономічної діяльності, запровадженням чітких та ефективних митних механізмів.

7. Реформа у сфері захисту економічної конкуренції шляхом запобігання зловживань великими компаніями, діяльність яких спотворює конкуренцію і обмежує можливості менших гравців ринку.

8. Реформа державної служби шляхом недопущення конфлікту інтересів при прийому на роботу службовців, антикорупційний контроль та зміну оплати праці державних службовців; скорочення державного апарату та оновлення його складу 3 постійними ротаціями працівників, що займають керівні посади.

9. Реформа освіти шляхом удосконалення механізму соціальних стипендій i інших виплат; підготовці студентів за спеціалізацією - розкриття і розслідування економічних злочинів i корупції; введення гарячої телефонної лінії на час екзаменаційної сесії; проведення лекцій щодо прав та обов'язків суб'єктів освітнього процесу; відповідальність за корупційні дії - аж до заборони викладацької діяльності; поширення інформації про навчальний заклад та викладачів, залучених до корупційних дій.

10. Контроль за виконанням конкретних державних інвестиційних проектів, що здійснюється шляхом цільового 
призначення частини коштів, що виділяються на їх реалізацію, на організацію оперативного супроводу за витрачанням і списанням бюджетних коштів, можливо, створивши тимчасові підрозділи цільового призначення, які можуть бути структурними підрозділами НАБУ.

11. Подальше реформування антикорупційного законодавства шляхом удосконалення законодавчої бази, впровадження правової експертизи законодавства антикорупційної спрямованості; удосконалення системи охорони і захисту свідка.

12. Реформа програм соціальних пільг шляхом спрощення процедури реалізації соціальних програм за рахунок чіткого визначення кола осіб, які відповідають вимогам даної програми; перехід до системи адресної грошової допомоги для зниження корупційних стимулів

13. Відкритість і прозорість інформації, постійне вдосконалення інформаційного i матеріально - технічного забезпечення антикорупційної діяльності шляхом удосконалення механізмів перевірки достовірності декларацій про доходи державних службовців; контроль за поширенням економічної інформації, з метою запобігання ¥іi продажу; створення банку даних суб'єктів підприємницької діяльності, причетних до корупції, 3 метою виключення можливості їх участі у виконанні державних замовлень і контрактів; постійний моніторинг ринку корупційних послуг 3 метою зменшення його обсягів.

14. Формування культурно-етичних норм несприйняття корупційної поведінки громадським суспільством шляхом впровадження етичних кодексів професійної діяльності; стимулювання «доносів» на тих, хто здійснює службові правопорушення.

Запропоновані вище економічні рекомендації можуть лягти в основу формування антикорупційної політики країни. Однак, слід враховувати, що корупція, це не тільки економічне явище, а й соціальне. Протидія корупції запропонованими заходами, спрямованими на попередження та протидію їй, і здійснення на цій основі ефективної діяльності можливо лише за умови усвідомлення тих соціальних механізмів, які обумовлюють корупцію.

При розробці антикорупційної політики необхідно в обов'язковому порядку враховувати думку і готовність населення до протидії цьому явищу, його потенціал і можливості. Для цього необхідно здійснювати наступні заходи. 
1. Формування у громадськості впевненості в перемогу над корупцією шляхом популяризації прикладів успішних антикорупційних програм як у нашій державі так і в інших країнах.

2. Здійснення антикорупційного освіти.

3. Активне залучення інститутів громадянського суспільства до протидії корупції, забезпечення прозорості, відкритості та чесності в державному управлінні.

4. Розробка і популяризація стандартів ділової практики, де буде підкреслюватися престижність державної служби та моральна відповідальність осіб, що займають державні посади. Державні службовці повинні уникати дій (поведінки), які можуть створити навіть видимість зловживань, оскільки це може відбитися на довірі до державного апарату та уряду.

5. Розробка програми боротьби з конфліктом інтересів, заснованої на кодексі ділової етики і підкріпленої юридичними санкціями.

6. Проведення адміністративної реформи шляхом модернізації та оптимізації державної служби, діяльність якої повинна бути прозорою для громадянського суспільства 3 можливістю публічного контролю. Саме це має бути основною метою модернізації державної служби. Громадський контроль дозволить попереджати, виявляти і усувати обставини, які сприяють корупції та зловживанням на державній службі та дозволить одночасно підвищити якість і ефективність їх роботи.

7. Розробка державної виховної програми з протидії корупції, розрахованої на всі вікові групи для зміни самого менталітету громадян і збільшення в цьому ролі ЗМІ та некомерційних організацій. Це має бути виражено у вигляді осуду громадською думкою всіх проявів корупції та самих корупціонерів, коли страждає репутація такого службовця і стає неможливою його подальша кар'єра.

Отже, одним із важливих чинників протидії деструктивному впливу корупції на сталий соціально-економічний розвиток держави $\epsilon$ ефективна антикорупційна політика, яка повинна відповідати сучасним умовам розвитку держави, враховувати масштаби поширення корупції в суспільстві, зокрема і в зонах підвищеного корупційного ризику, передбачати основні напрями протидії системній корупції та ефективні механізми моніторингу, оцінки та звітності за результатами здійснення антикорупційних заходів.

\section{Список використаних джерел}

1. Про засади державної антикорупційної політики в Україні (Антикорупційна Стратегія) на 2014-2017 роки: Закон України від 14 
жовтня 2014 року № 1699-VII [Електронний ресурс]. - Режим доступу : http://zakon4.rada.gov.ua/laws/show/1699-18

2. Про Стратегію сталого розвитку «Україна - 2020»: Указ Президента України від 12 січня 2015 р. № 5/2015 / Президент України. Офіц. Вісн Президента України, 2015. - № 2.

Підчоса О.В. к.е.н., доцент, Інститут міжнародних відносин Київського національного університету імені Тараса Шевченка

\section{ЗАГАЛЬНИЙ ОГЛЯД ОСНОВНИХ ВИДІВ ТРАНСПОРТНИХ ЗВ'ЯЗКІВ МІЖ ЄВРОПОЮ ТА АЗІЕЮ: РОЛЬ КРАЇН СХІДНОЇ ЄВРОПИ, ЩО НЕ ВХОДЯТЬ ДО ЄС}

Інфраструктура та транспорт, наявність та якість яких надзвичайно важливі, $€$ основою будь-якого економічного співробітництва, як всередині країн так і в умовах їхньої взаємодії 3 зовнішніми акторами. Розвиток існуючих транспортних шляхів i створення нових дозволять країнам Свропи та Азії, а також державам, які є транзитними хабами за своїм географічним положенням, брати участь у створенні та розвитку глобальних ланцюгів створення вартості. Диверсифікація транспортних зв'язків, оптимізація витрат, пов'язаних $з$ логістикою, а також оптимізація витрат часу поставок $\epsilon$ важливими складовими успішної торгівлі та інвестицій, що сприяють збільшенню потоків товарів, послуг, капіталу та праці.

Одним 3 найважливіших кроків у цьому відношенні було започаткування проекту Євро-Азіатських транспортних зв'язків (ЄAT3, англ. - EATL) у 2002 році як спільної діяльності Європейської економічної комісії ООН (СЕК ООН) та Економічної та соціальної комісії ООН для Азії та Тихого океану (UNESCAP). Проект визначає основні євро-азіатські авто- та залізничні маршрути для пріоритетного розвитку та співробітництва [1]. До держав-учасниць також входять країни Східної Свропи, що не входять до ЄС, такі як Україна, Білорусь, Молдова, Російська Федерація, а також інші країни Азії.

На відміну від морського і повітряного транспорту, вартість товарів, що перевозяться залізничним транспортом, істотно зросла протягом 2011-2016 років (табл. 1). Очікується, що може зрости частка внутрішніх маршрутів у перевезенні чутливих до часу вантажів, таких 
як високоцінні компоненти в автомобільній або комп'ютерній промисловості [2, р. 42].

Таблиця 1

\section{Середня вартість 1 тони вантажу, що транспортусться між ЄС та КHP}

за видами транспорту в 2011-2016 роках (дол.США)

\begin{tabular}{|l|c|c|c|c|c|c|c|}
\hline $\begin{array}{c}\text { Види } \\
\text { транспорту }\end{array}$ & $\mathbf{2 0 1 1}$ & $\mathbf{2 0 1 2}$ & $\mathbf{2 0 1 3}$ & $\mathbf{2 0 1 4}$ & $\mathbf{2 0 1 5}$ & $\mathbf{2 0 1 6}$ & $\begin{array}{c}\mathbf{2 0 1 6 / 2 0 1 1 ,} \\
\mathbf{\%}\end{array}$ \\
\hline Із Китаю до Свропейського Союзу \\
\hline Морський & 4865 & 4886 & 4353 & 4440 & 4925 & 4174 & 85.8 \\
\hline Залізниця & 5057 & 6023 & 5956 & 7956 & 9068 & 9841 & 194.6 \\
\hline Авіа & 79266 & 83342 & 71676 & 65206 & 81772 & 75931 & 95.8 \\
\hline Із Свропейського Союзу до Китаю \\
\hline Морський & 3125 & 3016 & 3027 & 3215 & 2400 & 2273 & 72.8 \\
\hline Залізниця & 3056 & 4946 & 10083 & 10130 & 8647 & 12057 & 394.5 \\
\hline Авіа & 83047 & 88239 & 76615 & 101073 & 87011 & 74154 & 89.3 \\
\hline
\end{tabular}

Джсерело: [2, pp. 41-42].

Залізниці значною мірою сприяли розвитку торгівлі та транзиту уздовж маршрутів через розвиток транспортних зв'язків Азії та Європи. Залізничний транспорт обслуговував внутрішньорегіональний експорт великих обсягів вантажів та їх доставку в морські порти, обсяг контейнерного вантажообігу 3 кожним роком зростав на більшості євразійських маршрутів [2, p.47-48]. У кожному з них можна побачити принаймні 1 Східноєвропейську країну, що не входить до СС (табл. 2). Загалом, Таблиця 2 демонструє важливість місця, яке надають Східноєвропейським країнам, що не входять до $Є C$, у розвиток транспортного зв'язку між Азією та Європою.

Таблиця 2

\section{Залізничні шляхи в рамках проекту Свро-Азіатських}

\section{транспортних зв'язків}

\begin{tabular}{|l|l|}
\hline 1 & $\begin{array}{l}\text { Транссибірська залізниця, Північний шлях } \\
\text { Захід (Фінляндія, Латвія, Литва, Польща, Угорщина) до Сходу } \\
\text { Перетинає країни: Російська Федерація, Білорусь або Україна } \\
\text { Кількість змін колії: 0 }\end{array}$ \\
\hline 2 & $\begin{array}{l}\text { Транссибірська залізниця, Південний шлях } \\
\text { Захід (Північ та Схід ЄС (Фінляндія, Литва, Польща, Угорщина)) до Сходу (Китай) } \\
\text { Перетинає країни: Україна, або Білорусь, Російська Федерація, Казахстан, Китай } \\
\text { Кількість змін колії:: 1 (Казахстан / Китай) }\end{array}$ \\
\hline 3 & $\begin{array}{l}\text { Захід (Південний Схід ЄС (Угорщина, Румунія, Болгарія) через Кавказ та Центральну } \\
\text { Азію до Сходу (Китай) } \\
\text { Перетинає країни: Молдова, Туреччина, Грузія, Азербайджан, Вірменія, Туркменістан, } \\
\text { Узбекистан, Таджикистан, Киргизстан, Казахстан, Китай } \\
\text { Кількість змін колії:: 1 (Казахстан / Китай) Кількість паромних переходів: 2 (Каспійське } \\
\text { і Чорне море) }\end{array}$ \\
\hline 4 & $\begin{array}{l}\text { Південний Шовковий шлях або шлях через Свропу до Азії } \\
\text { Захід (Південний Схід ЄС (Болгарія) через Іран і Центральну Азію до Сходу (Китай) }\end{array}$ \\
\hline
\end{tabular}




\begin{tabular}{|l|l|}
\hline & $\begin{array}{l}\text { Перетинає країни: Туреччина, Іран, Туркменістан, Узбекистан, Казахстан, Китай } \\
\text { Кількість змін колії: } 2 \text { (Іран / Туркменістан, Казахстан / Китай }\end{array}$ \\
\hline 5 & $\begin{array}{l}\text { Північ (Північ СС (Фінляндія)) через Кавказ і Центральну Азію на Південь (Іран) } \\
\text { Перетинає країни: Російська Федерація, Азербайджан, Іран, Туркменістан, Казахстан, } \\
\text { Узбекистан } \\
\text { Кількість змін колії: } 1 \text { (Казахстан / Китай) } \\
\text { Кількість паромних переходів: } 1 \text { (Чорне море) }\end{array}$ \\
\hline 6 & $\begin{array}{l}\text { Захід (Схід ЄС (Угорщина, Польща)) через Центральну Азію до Сходу (російське } \\
\text { тихоокеанське узбережжя) } \\
\text { Перетинає країни: Україна, Молдова, Російська Федерація, Казахстан } \\
\text { Кількість змін колії: 0 }\end{array}$ \\
\hline 7 & $\begin{array}{l}\text { Захід (Схід СС (Угорщина та Польща)) через Центральну Азію до Сходу (Китай) } \\
\text { Перетинає країни: Україна, Казахстан, Узбекистан, Китай) } \\
\text { Кількість змін колії: 1 (Казахстан / Китай) }\end{array}$ \\
\hline 8 & $\begin{array}{l}\text { Північ (Північ та Схід ЄС (Латвія, Польща та Литва)) через Кавказ до Півдня } \\
\text { (Азербайджан, Іран) } \\
\text { Перетинає країни: Україна, Російська Федерація, Грузія, Азербайджан, Іран } \\
\text { Кількість змін колії: 1 (Азербайджан /Іран) }\end{array}$ \\
\hline 9 & $\begin{array}{l}\text { Північ (Північ СС) Фінляндія) та Балтійська частина Російської Федерації) через } \\
\text { Центральну Азію-Південь (Центральна Азія) } \\
\text { Перетинає країни: Російська Федерація, Казахстан, Узбекистан, Таджикистан } \\
\text { Кількість змін колії: 0 }\end{array}$ \\
\hline
\end{tabular}

Джерело: [2].

Проте останні події в Україні, які призвели до військового конфлікту у східній частині держави та ембарго, введеного Російською Федерацією на транзит цілого ряду українських товарів через іiі територію, значно ускладнили становище України на перехресті шляхів з Азії до Європи. Але ми вважаємо, що це тимчасові труднощі, і вони будуть подолані.

Східноєвропейські країни, що не входять до $\mathrm{CC}$, також $\epsilon$ частиною 2 маршрутів, в рамках Ініціатив поясу та шляху КНР: Новий Свразійський сухопутний економічний коридор, економічний коридор Китай-Центральна Азія-Західна Азія [5; 6; 7].

Автомобільний транспорт обслуговував переважно міжрегіональні зв'язки у торгівлі між Азією та Європою [2, p. 86]. Фаза III проекту САТЗ охоплювала різні програми та проекти, для переміщення вантажів між Свропою та деякими азіатськими країнами. Укладено 286 двосторонніх договорів про дорожній транспорт. Ці угоди застосовуються лише в 12 країнах Євразії, включаючи 4 східноєвропейські країни, що не входять до $\mathrm{CC}$, таких як Білорусь, Молдова, Росія та Україна. Згідно зі звітом ЄЕК ООН, дорожні транспортні перевезення між Китаєм та європейськими країнами (без зміни вантажівок та перевантаження на маршруті) не проводилися до 2017 року, хоча вони залучені до торгівлі та транзиту товарів між Європою та Центральною Азією [2]. 
За даними ЮНКТАД, Свростату, МААТ, МСЗ, Корпорації Боїнг та їх контейнерної статистики на етапі III проекту САТЗ (2013-2017) євразійська торгівля забезпечувалася головним чином морськими маршрутами. Приблизно 97\% вантажів за своїм обсягом (у метричних тонах) і майже 70\% вантажів за їхньою вартістю (у дол. США) транспортувалися морським транспортом. Частка повітряних вантажів у вантажних перевезеннях між Свропою та Азією становила менше 2\% за обсягом і близько $30 \%$ за вартістю. Залізниці перевозили $1 \%$ вантажів за обсягом і більше $2 \%$ за вартістю [2, с. 40].

Морські порти мають велике значення для країн САТЗ. Роль морських портів у євро-азіатській торгівлі розвивалася разом 3 прогресом у розвитку ланцюгів поставок. Внутрішні логістичні центри, термінали і сухі порти в Свропі та Східній Азії ставали важливими консолідаційними хабами для морських портів [2]. Чорноморські порти - Іллічівськ/Одеса (Україна), Варна, Бургас (Болгарія), Констанца (Румунія), Новоросійськ (Росія), Поті і Батумі (Грузія), Трабзон (Туреччина) обслуговують ряд східно-західних ЄвроАзіатські залізничних та дорожних шляхів, включаючи інтермодальні послуги через регулярні поромні i Ro-Ro лінії. У Чорноморському регіоні найбільшими портами за пропускною спроможністю були Констанца з 0,7 млн. TEUs (двадцяти фунтовий еквівалент) (2016р.), Новоросійськ - 0,6 млн. TEU (2016 р.) та Одеса - 0,5 млн. TEU (2016 р.). На закінчення, морські порти, розташовані в зоні САТЗ, відігравали подвійну роль в експлуатації євроазіатських внутрішніх транспортних зв'язків [2].

В результаті поліпшення паливної ефективності літаків, розвитку електронної комерції та логістики повітряного транспорту, цивільна авіація почала відігравати все більш важливу роль у сприянні торгівлі між Європою та Азією, конкуруючи як з морським, так і з сухопутним транспортом. Вантажні повітряні перевезення на торгових шляхах, що з'єднують Азію 3 Європою, значно перевищили довгострокову тенденцію - з 2000-х до 2017 року. У 2015 році вантажні авіаційні товари становили менше $1 \%$ тоннажу світової торгівлі, хоча повітряні перевезення складали 35\% вартості світової торгівлі. Згідно з даними Boeing, ринок Європи та Азії складав приблизно 20,3\% світового повітряного вантажообігу в тонна-кілометрах і 10,5\% у тоннажі. Авіаперевезення в Свропі та Азії з 1995 року зростали в середньому на $6,4 \%$ на рік. Ринок зріс на $6,0 \%$ у 2014 році та на $6,5 \%$ у 2015 році [2].

У 2017 році загальний середній рівень сполучення аеропортів в Європі збільшився на $3,8 \%$, що свідчить про значне розширення потужності авіакомпаній. Транспортні зв'язки на ринку поза межами 
СС зростали набагато повільнішими темпами - на 1,4\%, з втратами в Туреччині (6\%). Turkish Airlines разом з авіакомпанією Gulf Airlines отримали зростаючу частку ринку непрямого зв'язку між $\mathrm{CC}$ та Азіатсько-Тихоокеанським регіоном (19\%, порівняно з 4,9\% у 2007 році) - переважно за рахунок трьох найбільших європейських груп (Air France / KLM, IAГ та Lufthansa Group знизили свою частку ринку 3 $60,6 \%$ до $41,8 \%$.

\section{Список використаних джерел}

1. UNECE. (2019). Transport. [Електронний ресурс] Отримано 3: https://www.unece.org/trans/main/eatl/about_us.html

Отримано

2. UNECE. (2019). $3^{\text {rd }}$-phase Report. [Електронний ресурс] https://www.unece.org/fileadmin/DAM/trans/doc/2018/itc/Informal_docu ment_No_8_EATL_3rd-phase_report.pdf

3. World Bank. (2013). Quantitative Analysis of Road Transport Agreements (QuARTA). [Електронний pecypc] Отримано 3: http://documents.worldbank.org/curated/en/175601468157187988/pdf/768 250PUB0EPI00IC00PUB0DATE04013013.pdf

4. Airports Council International. (2017). Airport Industry Connectivity report. [Електронний pecypc] Отримано 3: http://www.seo.nl/uploads/media/2017-

36_ACI_EUROPE_Airport_Industry_Connectivity_Report_2017.pdf p. 41

5. OBOR Europe. Belt and Road Initiative. [Електронний ресурс] Отримано 3: https://www.oboreurope.com/en/beltandroad/one-belt/

6. Eurasia Trans Service. (2017). Ukraine formally joined the TransCaspian transport route. [Електронний pecypc] Отримано 3: https://www.etservice.com.ua/en/post-2-en/

7. Belt and Road Centre Hungary. (2017). East-Central Europe on the New Silk Road. [Електронний pecypc] Отримано 3: http://beltandroadcenter.org/2017/11/07/east-central-europe-on-the-newsilk-road/ 
Київський національний торговельно-економічний університет

\section{ВПЛИВ ІНФОРМАЦЙНОЇ АСИМЕТРІЇ НА ДЕФОРМАЦІЮ СПОЖИВЧОГО ПОПИТУ В УКРАЇНI}

Ринок споживчих товарі та послуг - це один із найбільш
стратегічно важливих напрямків будь-якої сучасної економіки. Розвинений ринок споживчих товарів та послуг - це перша ознака розвиненої та цивілізованої економіки. Високий рівень попиту на споживчі товари та послуги є ознакою платоспроможності населення країни. Зазначений попит в свою чергу має бути забезпечений якісною та своєчасною пропозицією.

За рахунок зручного географічного положення та достатньо великої кількості населення український ринок має значний потенціал для подальшого розвитку. Підтвердженням зазначеного трактування $є$ те, що відповідно до Індексу Глобальної конкурентоспроможності в 2017 р. Україна посіла 47 місце серед 137 можливих за показником "місткість товарних ринків"[1].

Проте, у зв'язку з постійними трансформаційними економічними та політичними процесами в українській економіці відсутня певна стабільність, що має значний негативний наслідок на всі системи та процеси в країні.

Як наслідок для ринку споживчих товарів та послуг це проявляється в монополізації, невиправдано завищених цінах, ігноруванні споживчих уподобань, порушенні стандартів, тінізації масштабів діяльності тощо.

Одним із джерел походження зазначених проблем в Україні також $є$ інформаційна асиметрія.

Інформаційна асиметрія як явище, яке характеризує різний рівень проінформованості учасників ринкових відносин існувала ще 3 початку зародження ринку як такого. Проте найбільшого розвитку вона зазнала останні 50 років, які характеризувались потужним розвитком інформаційних систем та технологій та, на основі цього, розвитку нової економічної системи - економіки інформаційного типу на шляху до становлення якої сьогодні знаходиться наша держава.

Інформаційна асиметрія може мати об'єктивний характер, виникаючи на ринках всупереч рівномірному розподілу ресурсів i можливостей щодо просування власного товару. 
Проте найбільш розповсюдженими випадками поширення інформаційної асиметрії є саме ті, що мають суб'єктивний (умисний) характер - наприклад, коли окремі суб'єкти господарювання, володіючи та користуючись своєю ринковою владою, свідомо й агресивно просувають менш якісний товар з метою мінімізації власних витрат та максимізації прибутку [2].

Саме суб'єктивний характер поширення інформаційної асиметрії має найбільш руйнівний вплив на основні економічні процеси, що відбуваються на ринку.

Проявами суб'єктивного поширення інформаційної асиметрії є: поширення неправомірної реклами, що може стосуватись як зовнішніх, так і внутрішніх характеристик рекламованого товару; поширення інформації, що вводить в оману, що $є$ одним із найбільш поширених правопорушень та займає близько $80 \%$ від всього об'єму правопоушень у вигляді недобросовісної конкуренції; неправомірне використання ділової репутації іншого суб'єкта господарювання; створення перешкод іншим суб'єктам господарювання у процесі конкуренції; досягнення неправомірних переваг у конкуренції, неправомірне збирання, розголошення та використання комерційної таємниці тощо.

Загалом, поступово складається така ситуація на ринку за якої практично неможливим стає ведення чесної підприємницької діяльності.

Так, у 2016 р. Центром комплексних досліджень 3 питань антимонопольної політики проведено опитування керівників підприємств 3 метою визначення основних проблем і перспектив розвитку конкурентного середовища та, зокрема, проявів недобросовісної конкуренції. За результатами зазначеного дослідження встановлено, що у цей період прояви недобросовісної конкуренції відчули $37.9 \%$ респондентів. Серед них найбільша частка (19.1\%) зазначили, що про товар або діяльність їх підприємств поширювались неправдиві, неточні або неповні відомості [3].

Таким чином, на ринку споживчих товарів та послуг найбільш поширеними інструментами, що сприяють активному розповсюдженню інформаційної асиметрії, $\epsilon$ : приховування інформації про дійсну якість товарів та послуг; поширення неправдивої інформації про товари та послуги, їх якість, ціни, експлуатаційні характеристики тощо; неправомірне використання позначень; копіювання зовнішнього вигляду виробу конкурентів; дискредитація конкурентів; неправомірне використання їх ділової репутації; створення перешкод іншим суб'сктам господарювання у процесі 
конкуренції; досягнення неправомірних переваг у конкуренції; неправомірне збирання, розголошення та використання комерційної таємниці. Як наслідок, споживачі практично позбуваються можливості зробити ефективний економічний вибір, будучи змушеними нести додаткові трансакційні витрати на пошук та перевірку інформації, а також втрати від невдалого вибору, а споживчий добробут скорочується через зростання величини таких витрат та втрат.

Проте споживачі не є єдиними учасниками ринкових відносин, які несуть втрати від поширення інформаційної асиметрії. Інформаційна асиметрія за рахунок можливості спотворення попиту на ринку здатна впливати на конкурентні відносини між суб'єктами господарювання навіть на ринках, які мають аналогічну структуру та примірно однаковий рівень концентрації.

А якщо нерівномірний розподіл інформації укорінюється в ринкових інститутах, то втрати нестимуть вже не тільки окремі споживачі, але й усі безпосередні учасники ринкових відносин.

\section{Список використаних джерел}

1. Економічний дискусійний

клуб.

URL: edclub.com.ua/analityka/pozyciya-ukrayiny- v-reytyngu-krayin-svitu-zaindeksom-globalnoyi-konkurentospromozhnosti-2.

2. Мазуренко В.П. Вплив інформаційної асиметрії на функціонування товарних ринків. URL: //http://jrnl.nau.edu.ua/index.php/SR/article/viewFile/7098/7943.
3. Антимонопольний
комітет
України
URL: http://www.amc.gov.ua/amku/doccatalog/document?id=133712\&schema= mai.

Смагін В.Л., д.е.н., професор, Київський національний лінгвістичний університет

\section{МЕТОДОЛОГІЧНЕ ПІДГРУТЯ ФУНКЦІОНУВАНЯ ФІНАНСОВОГО РИНКУ В УМОВАХ СИСТЕМНИХ ТРАНСФОРМАЦЙ}

3 кінця XX-початку XXI ст. Україна перебуває в стані системної трансформації, під якою переважна частина вітчизняних та зарубіжних дослідників розуміє «перетворення, які охоплюють увесь спектр 
суспільного життя, його духовну, політичну, економічну та соціальну структури (перетворення політичного режиму, радикальне економічне реформування, духовно - культурну переорієнтацію суспільства). Водночас, системна трансформація поєднує структурні, функціональні та організаційні перетворення підсистем та компонентів тієї чи іншої складної системи» [1, с. 25], що диктує певні вимоги методів дослідження розбудови ринкової економічної системи.

Синтезувати все цінне і об'єднати в єдине ціле те, що накопичила теорія ринків можна лише на основі творчого застосування методології економічного дослідження.

3 огляду на брак єдиного розуміння методології економічної теорії в науковій літературі [2, с. 6] ми беремо за основу для аналізу об'єкта свого дослідження тлумачення сутності методології як системи принципів і способів організації та побудови теоретичної і практичної діяльності, а також учення про систему.

Синтезувати все цінне й об'єднати в єдине ціле все, що нагромадила економічна теорія 3 метою забезпечення нової якості економічного зростання світового та національного господарств, можна лише на основі творчого застосування сучасної методології інституціоналізму.

Цей підхід $\epsilon$ вкрай важливий саме для трансформаційної економіки. Причина цього-проблема суб'єкта і суб' єктивності в такій економіці. Г. Клейнер виокремив цілу низку соціально-інституційних функцій суб' єктів економіки, без виконання яких економічна система не здатна до функціонування і розвитку [3, с. 103-105]. Цей аспект проблеми стосовно саме трансформаційної економіки розглянув також російський економіст Р. Нурєєв. Позначивши таку економіку як «економіку фізичних осіб», він показав, що саме дефіцит суб'єктності робить економічну систему не тільки неефективною, а й такою що згасає [4].

Отже, для системних трансформації в економіці вельми важливо $\epsilon$ не просто проблема суб'єкта, а проблема ефективних міжсуб'єктивних зв'язків. Це пов'язане з тим, що в цих економіках формується новий економічний порядок, що реалізується в новій структуризації суспільства, у встановленні нових інститутів, які уособлюють органічне поєднання економічного, правового, соціального політичного станів у певному інституціональному середовищі. Адже воно суттєво впливає на ефективний стан функціонування економіки в якому забезпечується максимальна відкритість і прозорість укладання угод між учасниками ринку 3 
мінімальними трансакційними витратами, а також регулюється діяльність за допомогою конкретних важелів через стимули і санкції.

Подальший напрям дослідження, на наш погляд, вимагає формування вихідних методологічних посилок через триєдине твердження, що фінансовий ринок, як суспільний інститут в сучасній економіці, по-перше, $\epsilon$ складовою процесу інвестиційного забезпечення економічного розвитку країни; по-друге, функціонування фінансового ринку невіддільне від процесу руху власності; по - третє. перспективи й напрямки розвитку фінансового ринку визначаються загальними тенденціями змін у країнах з нестабільною економікою. Отже ідеться, насамперед про системність розуміння сутності фінансового ринку, комплексний вибір методів та інструментів його дослідження.

Досить важливим методологічним підходом сучасного інституціоналізму в плані пізнання фінансового ринку є його аналіз не в статичному стані, а в розвитку, динаміці. 3 позиції інституціонального підходу, як зауважує О.С. Сухарєв, «це тривалий у часі процес, який характеризується генетично обумовленою заміною старих інститутів новими, тобто автоматичною зміною правил, звичаїв або їх модифікацією, чи керованим інститутоутворенням. Інституціональна динаміка - сукупний термін,який передає загальну суть еволюції інститутів, але кожна із інституціональних структур, кожне правило може мати власну й унікальну траєкторію розвитку [5, c. 89]. Що стосується фінансового ринку, то даний методологічний підхід зумовлює його пізнання в динамічному процесі переходу його від нижчих до вищих досконаліших форм функціонування через використання історично-генетичного методу.

Методологія інституціоналізму в дослідженні фінансового ринку передбачає широке застосування описово - статистичного методу [6, c. 19]. Він дозволяє способом використання математичного апарату опрацювати наявну інформацію, що «має енергетичну природу i пов'язана з акумуляцією та набуттям специфічної форми суспільної енергії людей, можливості їі передавання у просторі часі» [7, с. 180]. Розглядаючи проблему фінансового ринку, ми будемо в першу чергу вести мову про економічну інформацію, яка посідає важливе місце в аналізі особливостей поведінки економічних суб'єктів, що приймають раціональні та ірраціональні рішення в інституціональному середовищі ринку. Ефективність того чи іншого рішення перебуває в прямій залежності від обсягу і повноти інформації якою володіє 
суб'єкт ринку з відповідним рівнем економічних знань, досвіду корпоративної культури.

Розв'язання конкретних завдань щодо досягнення необхідної забезпеченості фінансовими ресурсами 3 мінімальними трансакційними витратами в інституціональному середовищі фінансового ринку сьогодні і в майбутньому буде залежати від швидкості і якості фінансових операцій, що в кінцевому результаті визначатиме ефективність функціонування фінансового ринку. Інформація належить до надбань матеріальної та духовної культур і несе в собі традиції і цінності з минулого в сучасність через розвиток формальних і неформальних інститутів, що визначають психологічні, професіональні якості поведінки суб'єктів фінансових відносин.

У процесі формування фінансового ринку в Україні суттєвий вплив на його якісні параметри мають неформальні відносини та інститути, які домінують над формальними відносинами та інститутами. Цьому спряли певні історичні традиції та звичаї, що сформували специфічну національну економічну культуру.

На наш погляд, зародження неформальних стосунків у процесі реалізації економічних відносин як на мікро-, так і на макрорівні, започатковано ще в надрах адміністративно-командної економіки, незважаючи на існування жорстких формальних інститутів на всіх рівнях господарювання. Базовою причиною формування потужної системи неформальних інститутів став хронічний дефіцит на всіх рівнях господарювання 3 відповідним міжгалузевим дисбалансом. Відповідно, це породжувало потребу в реалізації економічних інтересів через стійкі нелегальні відносини, обумовлені браком необхідного суспільного інституту для вільного укладення угодконтрактного права.

Фундатори інституціоналізму надавали i надають важливе значення моральному змісту ринкових відносин [8, с. 4-17; 9, с. 42-45; 10, с. 43-53], цілком нехтуючи тим, що моральні принципи існують у масштабі особистого інтересу, здобутої вигоди. Особистий інтерес просто не може з'явитися без опори на етичні норми. Властивість цього інтересу, його спрямованість залежать від моральних мотивів, або інститутів моралі. Процес створення морального клімату в трансформаційній економіці вкрай складний, має властивість незмірності, але протиставляти інтерес моральності неможливо. Необхідно вести мову про моральний інтерес, тобто інтерес, який є позитивним для всіх суб'єктів фінансового ринку.

Це досить важливо в сучасних умовах наявності ажіотажної, ризикованої, спекулятивної діяльності посередників на фінансовому 
ринку, коли спекулятивний капітал оминає реальний сектор економіки i стає головним детонатором фінансових криз у суспільстві. Його ідеологія обмежень параметрів підприємницької діяльності може бути покладена в основу пошуку способів стримування спекулятивних операцій на фінансовому ринку, що досить важливо в умовах трансформаційної економіки.

У плані нашого дослідження слід звернути особливу увагу на взаємозалежність та взаємозв'язок економічних знань та економічної культури. Адже «економічна культура - це свого роду посередник між комплексом політико-правових, економічних та інших умов тієї чи іншої країни та економічної поведінкою суб'єктів господарювання. Можна сказати, що розвиток економіки є сумарним результатом дій мільйонів людей, які регулюються як зовнішніми інституціональними умовами їхньої діяльності, так і рисами економічної культури самих людей» [11, с. 132].

У сучасному світі спостерігається тенденція до появи нового досить важливого впливу на економічну культуру суспільства впливу, який сформувався в кінці XX ст. внаслідок бурхливого розвитку інтернет - технологій. Нині навіть можна говорити про появу електронної культури. Значимість цього феномену дає для нас підстави говорити про виникнення нової субкультури - електронної економічної культури. Цей новітній інститут дозволяє підвищити оперативність обміну інформацією, синхронізувати попит на фінансові активи 3 їх пропонуванням на фінансовому ринку, сприяти спеціалізації знань і збільшенню інформаційного потенціалу економіки в цілому.

Очевидним $є$ факт, що в країнах де відбуваються системні трансформації неабияку роль відіграє стабільність (сила) інститутів, що регулюють фінансовий ринок. Високий рівень ризику інвестицій в економіку i, зокрема, у фінансові активи країн з трансформаційною економікою - прямий наслідок слабкості та нестабільності їхніх інститутів. Відсутність державного контролю над інститутами фінансового ринку призводить до катастрофічних наслідків, проте його посилення автоматично не здатне вирішувати всі проблеми.

\section{Список використаних джерел}

1. Гражевська Н. I. Відображення трансформаційних процесів в системі категорій соціально-економічної динаміки // Економічна теорія: науковий журнал, 2007. - №4. С. 19-29. 
2. Степаненко С. В. Інституціональний аналіз економічних систем (проблеми методології). К.: КНЕУ, 2008. - 312 с.

3. Клейнер Г. Б. Эволюция институциональных систем // М., 2004. - $240 \mathrm{c}$.

4. Нуреев Р. Социальные субъекты постсоветской России: история и современность. Режим доступу: http//ie.boom.ru / Nureev / article/article. htm

5. Сухарев О. С. Институциональная теория и економическая политика: $\mathrm{K}$ новой теории передаточного механизма в макроэкономике: в 2 кн. - Кн. 1. Институциональная теорія. Методологический эскиз. М.: Экономика. 2007. - 516 с.

6. Паєтко Т. В. Методологічні аспекти фінансових досліджень // Економіка і держава: науковий журнал, 2008. - №10. - С. 37-52.

7. Степаненко С. В. Інституціональний аналіз економічних систем (проблеми методології). К.: КНЕУ, 2008. - 312 с.

8. Корнаи Я. Честность и доверие в переходной экономике // Вопрос экономики: научный журнал, 2003. - №9. - С.15-27.

9. Тобин Дж. Теорема о «невидимой руке» должна бать модифицирована // Рос. экон. журн, 2012. - №3. С. 44-49.

10. Шастико А. Фридрих Хайек и институционализм // Вопросы экономики: научный журнал, 1999. - №6. - С. 43-53.

11. Прутська О. О. Інституціоналізм і проблеми економічної поведінки. - К.: Логос, 2003. - 256 с.

Соколова Ю.О., к.е.н., доцент Національний університет «Запорізька політехніка»

\section{РОЗВИТОК РЕГІОНУ В КОНТЕКСТІ КОНЦЕПЦЇ̈ ІНКЛЮЗИВНОСТІ}

Одним 3 найбільш дискусійних питань сьогодення, що обговорюються світовою науковою спільнотою, є питання про те чому одні країни процвітають в економічному відношенні, а інші ні. Тим більше, це питання є актуальним для України, яка володіє значним потенціалом розвитку завдяки своєму просторово-територіальному розташуванню (перетин Європейсько-Азіатських шляхів, логістична доступність ринків Близького Сходу та Африки); людським ресурсам 
(трудовим і науковим); кліматичним умовам та земельним ресурсам; умовам для розвитку альтернативної енергетики та енергозберігаючих технологій. Але наявний величезний потенціал національної економіки витрачається марно, через неефективну економічну політику, відсутність дієвого законодавства та програм розвитку, значних проблем, пов'язаних з корупцією, низькою продуктивністю, відсутністю інвестицій.

Д. Аджемоглу та Д. Робінсон в своїй праці «Чому нації занепадають? Походження влади, багатства i бідності» [1] стверджують, що ступінь розвитку національної економіки безпосередньо залежить від інклюзивних економічних інститутів, які забезпечують роботу двох найважливіших рушійних сил економічного зростання: технологічних інновацій та освіти. А безпосередньо стійке економічне зростання майже завжди супроводжується технологічними інноваціями, які підвищують продуктивність всіх трьох чинників виробництва: людська праця, землі та капіталу. Інклюзивні економічні інститути створюють інклюзивні ринки, які, на відміну від вільного ринку, забезпечують рівні можливості доступу до ресурсів.

Якщо розглядати Україну, то зараз окремі регіони дуже різняться за рівнем розвитку та економічного зростання, що зумовлено історичними чинниками, складом та структурою галузей економіки, які переважають в тому чи іншому регіоні, рівнем адаптивності до сучасних умов господарювання, рівнем інноваційного та інвестиційного розвитку. Отже, на нашу думку, одним з чинників успішного зростання національної економіки є забезпечення умов для розвитку регіонів.

Слід погодитися з думкою А.В. Пелашко про те, що ефективність функціонування регіону залежить не лише від рівня розвитку країни, а насамперед від способів управління економікою, соціальноекономічних відносин та особливостей використання місцевих ресурсів [2]. Таким чином, для ефективного розвитку регіону необхідно формування структури управління, що грунтується на принципах раціонального використання всіх видів ресурсів при збереженні сприятливого навколишнього середовища. Ефективний розвиток регіону також передбачає постійне зростання його соціальноекономічного та промислового потенціалу.

Інструментом такого зростання може стати сучасна концепція логістики, яка слугує підгрунтям для побудови інклюзивних економічних інститутів. Вона втілює у собі мікс 3 інформаційної, маркетингової та інтегральної концепцій логістики, реалізуючи системний підхід до організації матеріальних, інформаційних, 
фінансових потоків, сприяє побудові ефективних ланцюгів постачань та забезпечує цілісний підхід до інклюзивного зростання регіону. Головною метою при цьому повинно стати створення та розвиток логістичної інфраструктури, яка повинна враховувати всі виклики та проблеми людства на сучасному етапі розвитку економіки, серед яких $\epsilon$ :

- екологічні (забруднення повітря, води, землі, знищення лісів, зростання середньорічних температур, зникнення цілих екосистем);

соціальні (поведінка споживача, яку може охарактеризувати як «показове споживання», бажання купувати нові речі у відповідності до сучасних трендів та моди, прагнення належати до певної соціальної групи та відповідати їй за кількістю та складом необхідних атрибутів (одягу, аксесуарів, технічних приладів тощо), що призводить до перевантаження виробничих ресурсів, необхідності будувати все нові інфраструктурні об'єкти для забезпечення попиту, що зростає);

виробничі (поступове зникнення традиційних для економіки України галузей - металургія, машинобудування тощо; поява нових галузей - альтернативна енергетика, інформаційні технології; комунікації та транспорт, новітні підходи до просування товарів та послуг, зміна технологічних укладів).

Системний характер логістичного підходу дозволяє інтегрувати регіональні виробництва, канали розподілу, об'єкти інфраструктури 3 метою досягнення оптимального результату за мінімальних витрат.

Маркетингова складова сучасної концепції логістики пов'язує іiі 3 пануючою нині концепцією холістичного маркетингу, яка гарантує розширений інтегрований підхід до вирішення виробничих, соціальних, економічних та інших проблем ринку (регіону).

Запорізький регіон, - один з найбільш розвинених, в минулому, промислових регіонів України, який сьогодні практично втратив промисловість IV (виробничі ланцюги, родинні та підтримуючі галузі виробництва кольорових металів - ПАТ «ЗАлК», виробництва феросплавів) та V (радіо та приборобудівництво - ЗДП «Радіоприбор», завод «Гамма», ПАТ «Завод Перетворювач», ПАТ «Запоріжтрансформатор»; автомобілебудування - ПАО «ЗАЗ») технологічних укладів через неможливість доступу до традиційних ринків збуту та низьку конкурентоспроможність на глобальному ринку і перетворився на депресивний регіон. Занепад традиційної для регіону промисловості призводить не лише до негативних економічних наслідків, але й до значних соціальних потрясінь, відтоку 
працездатного населення та кваліфікованих трудових ресурсів, прояву соціальних захворювань суспільства, руйнування інфраструктури.

Водночас Запорізькому регіону вдалося зберегти виробництво авіадвигунів та надати йому подальший розвиток шляхом центрованої диверсифікації - будівництво сучасних гелікоптерів (АТ «Мотор Січ»). Поступово зароджуються компанії VI технологічного укладу (IT-сфера, альтернативна енергетика, логістичні центри та інші), які змінюють профіль регіону та роблять його промисловість більш сучасною та інноваційною. Ситуація, що склалася вимагає від керівництва регіону пошуку нових ефективних шляхів та інструментів для збереження його промислового статусу, розвитку інноваційних галузей, приваблення інвестицій та кваліфікованих фахівців.

\section{Список використаних джерел}

1. Аджемоглу Д., Робінсон Д. Чому нації занепадають? походження влади, багатства та бідності. - Київ: Наш формат, 2016. $472 \mathrm{c}$.

2. Пелашко А.В. Логістичний підхід до формування регіональної політики з метою підвищення ефективності соціально-економічного розвитку в післякризовий період / Наукові праці НДФІ. - 2012. - №4 (61). - C. 104-106.

Соколовська І.П., к. е. н., доцент, Київський національний торговельноекономічний університет

\section{ПЕРЕДУМОВИ ВІДНОВЛЕННЯ КРЕДИТУВАННЯ ЕКОНОМІКИ УКРАЇНИ}

Необхідною умовою відновлення стійких темпів економічного зростання в Україні $є$ ефективне використання наявних фінансових ресурсів. За висловом відомого дослідника проблем глобальної конкурентоспроможності професора Клауса Шваба, в умовах стрімкого поширення четвертої промислової революції у виграші залишаться лише країни з ефективним інтелектуальним та фінансовим капіталом [1]. Як відомо, одним із чинників, що визначає ефективність використання фінансового потенціалу економіки, є здатність фінансового ринку акумулювати вільні ресурси суб'єктів економіки та трансформувати їх в інвестиційні витрати підприємницького сектору. 
Особливістю українського фінансового ринку $є$ значне домінування активів банківського сегменту, що становить понад $80 \%$ від загальних активів всього фінансового ринку України. Науковці пояснюють це низьким рівнем довіри до небанківських фінансових посередників, нерозвиненістю національного ринку цінних паперів, та недостатньою активністю населення на фінансовому ринку $[2,256]$.

Ефективність функціонування банківської системи України в рамках агрегованого індексу глобальної конкурентоспроможності Світового економічного форуму оцінюється вкрай негативно. Зокрема, серед індикаторів, які мали найнижчі бали при розрахунку субіндексу ефективності фінансового ринку України у 2018 р., були надійність банків, фінансування малого і середнього бізнесу, частка проблемних кредитів. Це свідчить про відсутність умов для виконання банками своєї головної функції - кредитування реального сектору економіки, та не дозволяє національному фінансовому ринку здійснювати оптимальний перерозподіл капіталу для стимулювання економічного зростання.

Фундаментальним внутрішнім чинником, що обумовлює кредитну рестрикцію в Україні, є відсутність підтримки економічної динаміки з боку монетарного регулювання Національного банку України. Навіть упродовж останніх кризових періодів економічного розвитку національної економіки основним цільовим орієнтиром НБУ було таргетування інфляції, тобто реалізація жорсткої монетарної політики.

Одним із наслідків стиснення грошової пропозиції є збереження високих відсоткових ставок, що обумовлює підвищення вартості кредитування. Упродовж 2018 р. ключова ставка НБУ поетапно підвищувалась з 16 до 18 \%, не зважаючи на зниження рівня інфляції до 9,9 \% за підсумками 2018 р. Як наслідок, відсоткова ставка за гривневими довгостроковими кредитами, що зазвичай розглядаються як фінансове джерело інвестицій в економіці, становить $25 \%$ (станом на 18.04.19 за даними статистичної звітності банків України), а обсяги кредитування суб' єктів господарювання лише за два місяці поточного року скоротились майже на 10 млрд. грн. (з 904,8 млрд. грн. на 01.02.2019 р. до 894,9 млрд. грн. на 01.04.2019 р.) [3].

Аналіз світової практики свідчить, що стрімке економічне зростання більшості країн супроводжувалось випереджаючим двохп'ятикратним нарощуванням показника монетизації економіки. Так, у періоди наздоганяючої модернізації в Японії рівень монетизації був підвищений в 2,4 раза, в Кореї - більш ніж у 5 р., у Сінгапурі - у 2,2, в Малайзії - у 4,2, в Індії - у 1,9 раза. На сучасному етапі середнє співвідношення грошової маси та ВВП у країн 3 розвиненою 
економікою перебуває в межах 60-80\%, а у тих, що ставлять за мету досягнення прискорених темпів зростання економіки, монетизація перевищує $100 \%$. Зокрема, у лідера світової економіки Китаю зазначений показник наближається до 200\% [4, 302].

Слід зазначити, що жорстка монетарна політика та обумовлена нею висока вартість кредитних ресурсів суттєво скоротили фінансову глибину економіки (вимірюється як частка кредитів у ВВП). За оцінками експертів, даний показник знизився більш ніж вдвічі за останні 5 років - із $64 \%$ у 2014 р. до $30 \%$ на початок 2019 року, що значно нижче, ніж в інших країнах. Зокрема, у Польщі фінансова глибина економіки становить 70\%, у Туреччині - 80\%, у країнах Сврозони - 160\%, в Японії - 180\% [5].

Суттєвим стримуючим чинником кредитування на сучасному етапі стало посткризове накопичення проблемної заборгованості у банківській системі, що обумовило значні кредитні ризики та вимагає формування банками значних обсягів резервних активів. Про масштаби даної проблеми свідчить визначений за міжнародними стандартами, згідно нових вимог НБУ до оцінки банками розміру кредитного ризику з активних банківських операцій, реальний рівень проблемних кредитів, виданих українськими банками - близько $60 \%$ на середину 2017 р., що є своєрідним антирекордом у світовій практиці. Наявність значної кількості непрацюючих кредитів є однією з головних загроз банківського сектора на сучасному етапі. Вона несе в собі значний ризик як для самих банків, так і для їхніх вкладників та інших кредиторів, підриває стійкість банківської системи та економіки країни в цілому через неможливість повноцінного відновлення кредитування суб'єктів господарювання.

Для зменшення розмірів накопиченої проблемної заборгованості у банківській системі необхідний комплекс заходів, серед яких у першу чергу ефективна судова та правоохоронна реформи для забезпечення надійного захисту та дотримання прав кредиторів. Крім цього, слід прискорити впровадження нових інструментів роботи 3 проблемною заборгованістю, які допоможуть банкам очистити баланси від проблемних кредитів і поліпшити стан кредитних портфелів. Слід також зазначити, що відновлення кредитування економіки неможливе без подальшого підвищення рівня рентабельності підприємств реального сектору, який на сьогодні становить лише $11 \%$ та свідчить про низьку платоспроможність позичальників. Це потребує активізації заходів економічної політики щодо покращення регуляторних умов ведення підприємницької діяльності в країні. 


\section{Список використаних джерел}

1. The Fourth Industrial Revolution, by Klaus Schwab [Електронний ресурс] // Офіційний сайт Світового економічного форуму. - Режим доступу: https://www.weforum.org/about/the-fourthindustrial-revolution-by-klaus-schwab

2. Інноваційний розвиток корпоративних фінансів: тенденції та перспективи: монографія / [Терещенко О.О., Бабяк Н.Д., Іващенко А.І.та ін.]; за заг. ред. д.е.н., проф. О. Терещенка. - Київ : КНЕУ, 2017. $-495 \mathrm{c}$.

3. Процентні ставки за кредитами та депозитами [Електронний ресурс] // Офіційний сайт НБУ. - Режим доступу: https://bank.gov.ua/files/4-Financial_markets.xls

4. Чинники i тренди економічного зростання в Україні : колективна монографія / за ред. д-ра екон. наук М.І.Скрипниченко ; НАН України, ДУ «Ін-т екон. та прогнозув. НАН України». [Електронний ресурс] - Режим доступу: http://ief.org.ua/docs/mg/302.pdf

5. Фурман В. Чи потрібен кардіостимулятор для кредитування економіки в Україні [Електронний ресурс] // Режим доступу: https://www.epravda.com.ua/columns/2019/02/27/645605/

Стратійчук B.M., Київський національний торговельно-економічний університет

\section{АНАЛІЗ РИНКУ ТУРИСТИЧНИХ ПОСЛУГ УКРАЇНИ}

Ринок туристичних послуг можна розглядати як відкриту систему, що багатьма каналами (виробничо-технологічний, ресурсний, кадровий, інформаційний. фінансовий тощо) пов'язана 3 ринками вищих рангів (ринок послуг і світовий ринок) та 3 господарським комплексом певної території як з соціально-економічною системою вищого порядку, складовою якої $є$.

На сьогодні досить гострою залишається проблема дослідження туристичного ринку, зважаючи на посилення конкуренції на ньому серед вітчизняних виробників туристичних послуг та іноземних туристичних компаній. Відповідно, виникає необхідність у грунтовному дослідженні ринку туристичних послуг та його складових, що дасть змогу отримати об'єктивну інформацію про процеси, що відбуваються на туристичному ринку, та запропонувати 
дієві заходи щодо його розвитку. Однак специфічність туризму, як сфери економіки (об'єднує низку галузей: транспорт, зв'язок, готельне господарство, банки, сферу розваг тощо), зумовлює значні труднощі в отриманні економічної інформації для аналізу туристичної діяльності на всіх рівнях.

Дослідженням розвитку туристичного ринку України займалася низка науковців, зокрема Антонюк Н.В., Герасименко В.Г., Мальська М.П., Нещадим Л.М., Пастернак O.I., Тимчишин-Чемерис Ю.В., Тимчук С.В. та інші.

Метою написання даної роботи є здійснення аналізу сучасного стану та ретроспективи розвитку туристичного ринку України.

В процесі аналізу певного ринку, на нашу думку, на початковому етапі необхідно проаналізувати та оцінити стан ринку на момент здійснення аналізу. Для цього проаналізуємо динаміку основних показників туристичного ринку для розуміння сучасних тенденцій ринку та пріоритетів його розвитку [2].

Основними показниками туристичного ринку $\epsilon$ кількість підприємств, що надають туристичні послуги, а також обсяги доходів даних підприємств від надання туристичних послуг. Як видно на рис.1, динаміка кількості підприємств, що надають туристичні послуги в Україні була переважно спадною у 2013-2017 рр. Найбільше зниження кількості підприємств спостерігалося у 2015 році, коли кількість юридичних осіб, що надають туристичні послуги зменшилась на $-18,8$ $\%$ та фізичних осіб-підприємців - на 17,2 \%. Такі тенденції можна пов'язати із кризовими явищами в економіці України у 2015 році. В наступному році тенденція дещо покращилася, кількість юридичних осіб зросла на 3 \%, кількість фізичних осіб підприємців зросла на 19,4 $\%$. Проте у 2017 році кількість юридичних осіб знову зменшилася на 5,2 \%, а фізичних осіб підприємців зросла на 3,5 \%.

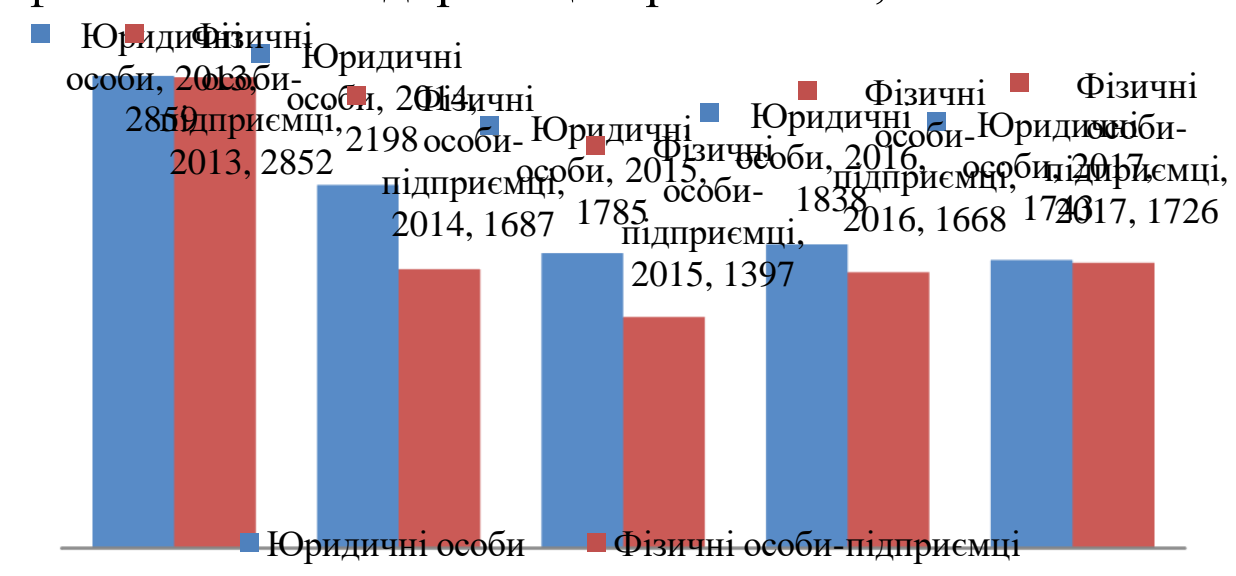

Рис. 1. Динаміка кількості підприємств туристичного ринку в Україні у 2013-2017 рр. (одиниць) [8] 
Не менш важливим ідентифікатором стану вітчизняного туристичного ринку, ніж кількість підприємств є обсяги одержаних туристичними підприємствами доходів.

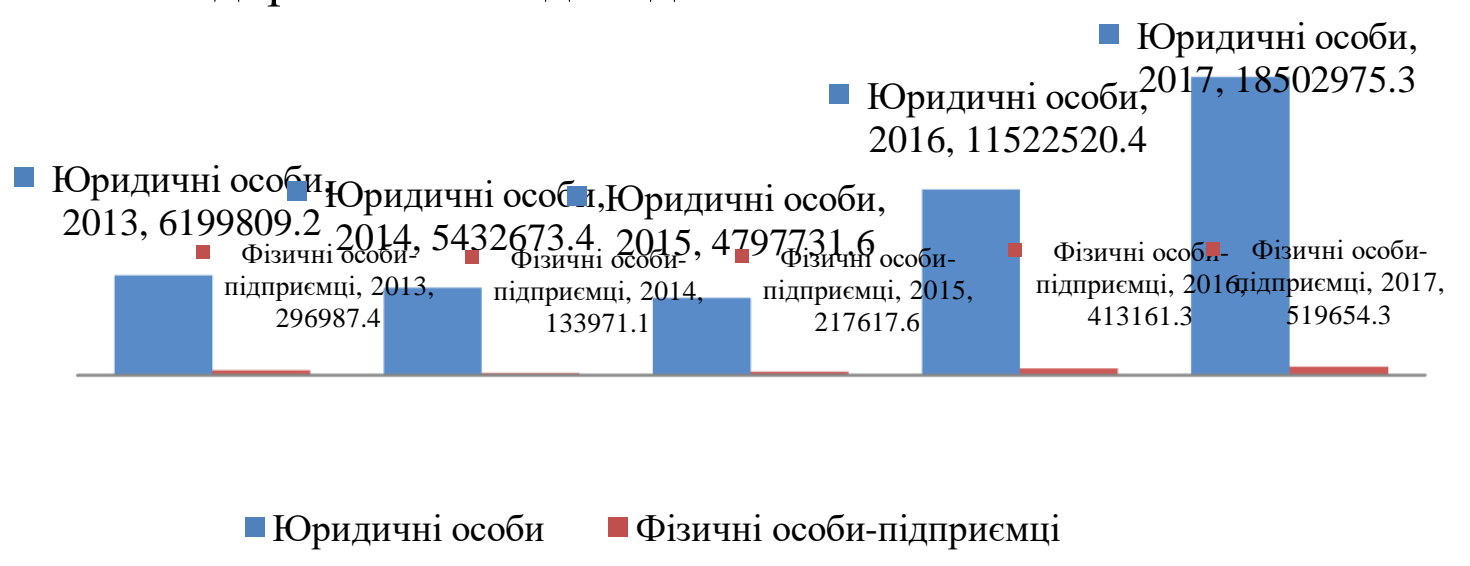

\section{Рис. 2. Динаміка доходу від реалізації туристичних послуг в Україні у 2013-2017 рр. (тис. грн.) [8]}

Згідно рис. 2., протягом 2013-2015 рр., спостерігалося зниження доходів від здійснення підприємницької діяльності в Україні, проте починаючи з 2016 року відбулися позитивні зрушення, що призводили до зростання обсягів доходів на туристичному ринку України. Так, у 2016 році дохід юридичних осіб від надання туристичних послуг зріс на 140,2 \%, дохід фізичних осіб-підприємців зріс на 89,9\%. У 2017 році приріст доходу юридичних осіб склав 60,6 \%, фізичних осіб підприємців - 25,8 \%.

Як видно з рисунків 1, 2, різниця між кількостями юридичних осіб та фізичних осіб-підприємців значно нижча, ніж між їх доходами, що свідчить про одержання значно більшої частини доходів юридичними доходами. На основі показника доходу від надання туристичних послуг визначимо динаміку часток ринку юридичних осіб та фізичних осіб підприємців.

Таблиця 1

Динаміка часток туристичного ринку юридичних осіб та фізичних осіб-підприсмців [8]

\begin{tabular}{|c|c|c|c|c|c|}
\hline Показник & 2013 & 2014 & 2015 & 2016 & 2017 \\
\hline $\begin{array}{c}\text { Дохід від надання } \\
\text { туристичних послуг } \\
\text { юридичних осіб, тис. } \\
\text { грн. }\end{array}$ & 6199809 & 5432673,4 & 4797731,6 & 11522520,4 & $\begin{array}{c}18502975 \\
, 3\end{array}$ \\
\hline $\begin{array}{c}\text { Дохід від надання } \\
\text { туристичних послуг } \\
\text { фізичних осіб- } \\
\text { підприємців, тис. грн. }\end{array}$ & 296987,4 & 133971,1 & 217617,6 & 413161,3 & 519654,3 \\
\hline
\end{tabular}




\begin{tabular}{|c|c|c|c|c|c|} 
Всього, тис. грн. & 6496797 & 5566645 & 5015349 & 11935682 & 19022629 \\
\hline $\begin{array}{c}\text { Частка ринку } \\
\text { юридичних осіб (\%) }\end{array}$ & 95,43 & 97,59 & 95,66 & 96,54 & 97,27 \\
\hline $\begin{array}{c}\text { Частка ринку } \\
\text { фізичних осіб (\%) }\end{array}$ & 4,57 & 2,41 & 4,34 & 3,46 & 2,73 \\
\hline
\end{tabular}

Аналіз часток ринку в розрізі фізичних осіб-підприємців та юридичних осіб свідчить, що протягом 2013-2017 рр. спостерігалася тенденція щодо переважання на ринку туристичних послуг юридичних осіб, протягом 5 останніх років частка юридичних осіб становила більше, ніж $95 \%$.

Крім виділення юридичних осіб та фізичних осіб-підприємців на туристичному ринку України, доцільно також проаналізувати динаміку часток ринку в розрізі видів туристичних підприємств.

Таблиця 2

Динаміка часток ринку туристичних послуг в Україні в розрізі видів туристичних підприємств за доходом у 2013-2017 рр. (\%) [8]

\begin{tabular}{|c|c|c|c|c|c|}
\hline Показник & 2013 & 2014 & 2015 & 2016 & 2017 \\
\hline $\begin{array}{c}\text { Частка ринку } \\
\text { туроператорів }\end{array}$ & 89,52 & 92,14 & 84,42 & 92,02 & 94,19 \\
\hline $\begin{array}{c}\text { Частка ринку } \\
\text { турагентів }\end{array}$ & 9,17 & 7,61 & 15,17 & 7,72 & 5,52 \\
\hline $\begin{array}{c}\text { Частка ринку } \\
\text { суб'єктів, що } \\
\text { здійснюють } \\
\text { екскурсійну діяльність }\end{array}$ & 1,31 & 0,25 & 0,42 & 0,26 & 0,30 \\
\hline
\end{tabular}

Проведений аналіз динаміки часток ринку різних видів туристичних підприємств за отримуваним доходом показав, що протягом останніх 5 років найбільшу частку ринку туристичних послуг в Україні складали туроператори, найменшу - суб'єкти, що здійснюють екскурсійну діяльність.

Однією з найголовніших характеристик туристського ринку, яка відображає рівень конкуренції на ньому, є концентрація ринку ступінь переважання однієї або декількох великих фірм [4]. 


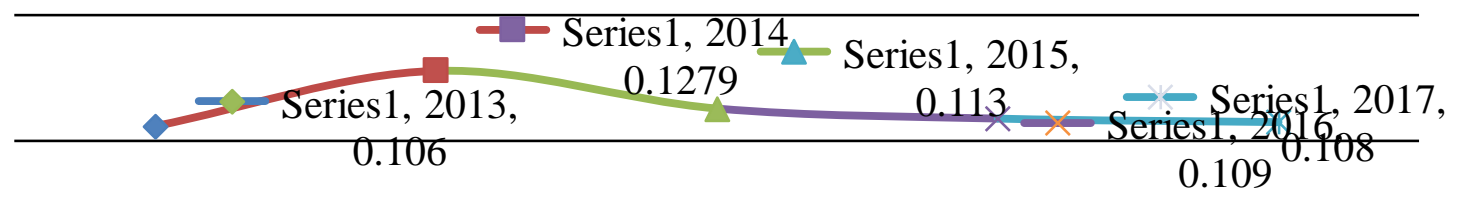

\section{Рис. 3. Динаміка індексу Герфінделя-Гіршмана на туристичному ринку України у 2013-2017 рр.}

Проведений аналіз індексу Герфінделя-Гіршмана на туристичному ринку України у 2013-2017 рр. показав, що значення індексу варіювалися від 0,1279 до 0,106 протягом останніх 5 років, що свідчить про те, що вітчизняний туристичний ринок був та залишається помірно концентрованим. Динаміка даного показника була зростаючою лише у 2014 році, починаючи із 2015 року спостерігалася тенденція щодо зниження індексу Герфінделя-Гіршмана. Така тенденція говорить про те, що на туристичному ринку України присутня велика кількість підприємств, що надають туристичні послуги.

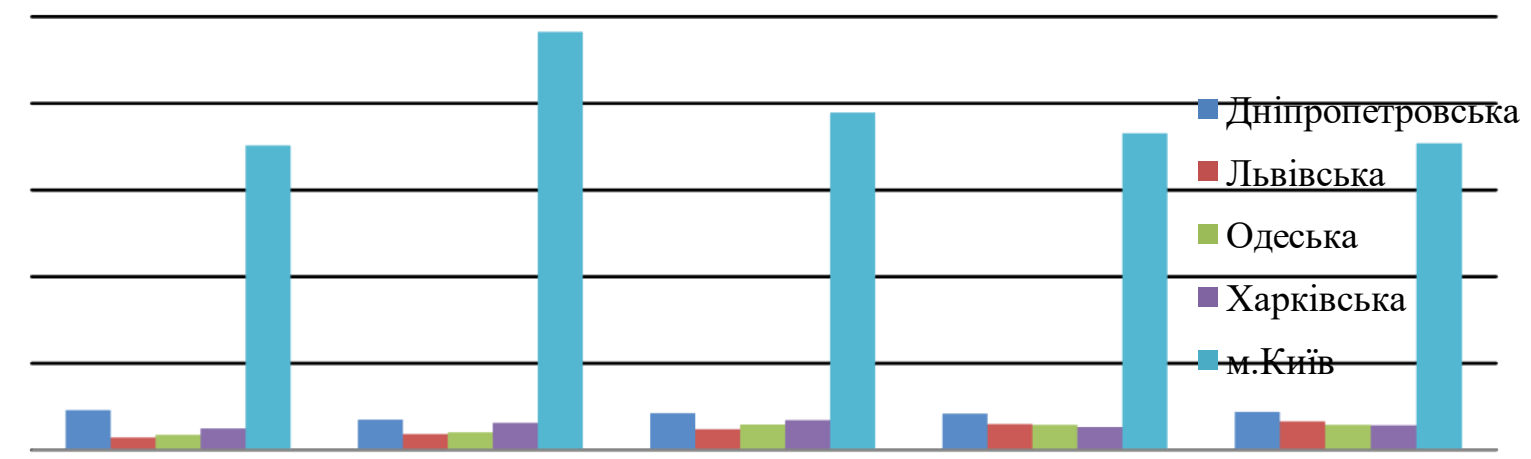

Рис. 4. Динаміка індексу Герфінделя-Гіршмана областей України із найбільшою концентрацією туристичних підприємств y 2013-2017 pp.

Як видно на рис. 5, найбільше туристичних підприємств в Україні сконцентровано в місті Київ, показник концентрації був найвищим у 2014 році, у наступних роках він дещо знизився. На другому місці Дніпропетровська область, далі ідуть Одеська, Львівська та Харківська області.

Таким чином, проведений аналіз показав, що у 2013-2017 рр. в Україні було зареєстровано більшу кількість туристичних агентів, ніж туристичних операторів. Проте обернено пропорційною є ситуація щодо одержання доходів, тобто більша кількість туристичних агентів 
приносить нижчий обсяг доходів, ніж значно менша кількість туристичних операторів. Проведений аналіз індексу ГерфінделяГіршмана показав, що на туристичному ринку України присутня велика кількість підприємств, що надають туристичні послуги. Найбільше туристичних підприємств в Україні сконцентровано в місті Київ, далі йдуть Дніпропетровська, Одеська, Львівська та Харківська області. Отже, протягом останніх 5 років туристичний ринок України інтенсивно розвивається, що приносить приріст доходів від їх функціонування та визначає туризм одним із найбільш динамічних та перспективних галузей вітчизняної економіки.

\section{Список використаних джерел}

1. Державне агентство України з туризму і курортів [Електронний pecypc]. - Режим доступу : http://tourism.gov.ua.

2. Міжнародний туризм і сфера послуг: Підручник. Затверджено МОН / Мальська М.П., Антонюк Н.В. - К., 2008. - 661 с.

3. Нещадим Л. М. Песпективні напрями диверсифікації туристичної діяльності в Україні / Л. М. Нещадим, С. В. Тимчук // Молодий вчений. - 2016. - № 8. - С. 27-30.

4. Ринки туристичних послуг: стан і тенденції розвитку : монографія / за заг. ред. професора В.Г.Герасименко. - Одеса : Астропринт, 2013. $-334 \mathrm{c}$.

5. Світова рада 3 туризму та подорожей / World Travel \& Tourism Council [Електронний ресурс]. - Режим доступ : http://www.wttc.org//media/files/reports/economic-impactresearch/2017-documents/globaleconomic-impact-and-issues-2017.pdf.

6. Світова туристична організація UNWTO [Електронний ресурс]. Режим доступу : http://www.unwto.org.

7. Тимчишин-Чемерис Ю. В. Напрями підвищення конкурентоспроможності підприємств туристичної справи в Україні / Ю. В. Тимчишин-Чемерис, О. І. Пастернак // Міжнародний науковий журнал "Інтернаука" . - 2017. - № 7. - С. 165-171.

8. Туристична діяльність в Україні у 2016 році : стат. зб. - К. : Державна служба статистики України, 2017. - 76 с. 5. Стратегія розвитку туризму та курортів на період до 2026 р. [Електронний ресурс]. Режим доступу : http://zakon2.rada.gov.ua/laws/show/16 
Струк Н. П.,

к.е.н., доцент, Івано-Франківський національний технічний університет нафти і газу

\section{ЯКІСТЬ ЖИТТЯ НАСЕЛЕННЯ: АНАЛІЗ БАЗОВИХ КОМПОНЕНТ}

Якість життя населення - багатоаспектне поняття, що охоплює широке коло соціально-економічних, національних, релігійних та інших відносин, які характеризують умови життедіяльності людини, сім’ї, різних соціальних верств населення окремих регіонів і країни в цілому. В період глибокої та системної економічної кризи проблеми стабілізації і зростання якості життя населення стають провідними. Саме тому аналіз базових компонент поняття «якість життя населення» не втрачає актуальності сьогодні.

У ході історичної еволюції багаторазово змінювалися підходи до визначення базових компонент якості життя. Це доводить, що існуючі трактування містять інтегральне, комплексне походження, яке змінюється під впливом розвитку суспільних відносин. Якість життя тісно пов'язана із добробутом населення і формується під впливом багатьох факторів. В процесі дослідження встановлено, що якість життя є складовою добробуту населення і включає об'єктивну та суб'єктивну компоненти. Об'єктивна компонента охоплює рівень та умови життя населення, а суб'єктивна - задоволеність життям.

Об'єктивну компоненту якості життя можна поділити на економічну, соціальну, екологічну (природну) та суспільно-політичну складові, або, іншими словами, на складові того середовища населення, яке формує якість його життя. Найбільш тісний зв'язок із якістю життя, на нашу думку, має економічна складова. Економічна складова якості життя населення охоплює реальні доходи населення (грошові та сукупні) у співвідношенні із споживчими цінами, зайнятість та умови праці, матеріальне становище тощо. Нормальне існування і розвиток людини можливі лише за умови безперервного споживання нею матеріальних і духовних благ [1, с. 7-11; 2, с. 43-48].

Саме тому виробництво останніх у суспільстві також повинно бути неперервним. Сучасне виробництво являє собою складний розгалужений і всеосяжний організм, який забезпечує життєдіяльність i певний рівень життя населення. Таким чином, між суспільним виробництвом i колом потреб людини, а також ступенем їх задоволення, тобто між виробництвом і рівнем життя людей, існує 
глибокий внутрішній взаємозв'язок. 3 одного боку, виробництво має вирішальне значення для рівня життя населення, потенційний життєвий рівень в основному визначається сукупною кількістю благ, які створюються, тобто залежить від обсягу ВВП на душу населення (наприклад, у вартісному вираженні). 3 іншого боку, підвищення життєвого рівня населення має бути основною метою розвитку суспільного виробництва [3, с. 83]. Соціальна складова охоплює охорону здоров'я, освіту, соціальне забезпечення, культуру, мистецтво, транспортну інфраструктуру, криміногенне середовище тощо. Екологічна складова - стан екології та навколишнього середовища, в якому проживає людина. Суспільно-політична складова залежить від суспільно-політичної ситуації і стану суспільного середовища. На нашу думку, об'єктивний підхід $\epsilon$ найбільш поширеним, він визначає якість життя через параметри об'єктивних умов і процесів життєдіяльності.

Суб'єктивна компонента (задоволеність життям) відбиває ставлення особистості до життя і до майбутнього. На нашу думку, суб'єктивний підхід зосереджений на розгляді ціннісних установок. Елементами структури якості життя $є$ самопочуття, задоволеність життям, щастя (чи комбінація цих елементів). В цьому контексті варто звернути увагу на економічну теорія щастя (еconomics of happiness) один 3 нових напрямків сучасних досліджень, який базується на концепції обмеженої раціональності, запропонованої нобелевським лауреатом Г. Саймоном. У центрі уваги - суб'єктивні уявлення особистості про задоволеність своїм життям як економічний феномен. Крім того, ця теорія розглядає, які економічні чинники і якою мірою визначають людське щастя, як щастя людини залежить від рівня економічного розвитку країни, які економічні параметри відображають «рівень щастя» суспільства в цілому, як відчуття людиною власного щастя впливає на результативність його економічної діяльності, як i міра відповідальності за щастя самої особистості і держави [4, с. 33].

Слід зауважити, що якість життя визначається системою критеріїв, кожен із яких дає уявлення про яку-небудь одну сторону життя населення. Щоб мати повне уявлення про якість життя, необхідне комплексне вивчення доходів населення, рівня і структури споживання матеріальних благ і різних послуг, забезпеченості житлом, предметами культурно-побутового призначення тощо.

Отже, сьогодні існує багато різних підходів до визначення якості життя. Вивчення цих підходів дозволяє зробити висновок про те, що до теперішнього часу серед більшості науковців відсутня єдність у іiі трактуванні. Тому виглядає цілком доцільним вивчення соціально- 
економічної категорії «якість життя» як такої, що постійно еволюціонує та аналізувати останню як комплексне, інтегральне поняття, яким визначаються і оцінюються об'єктивні та суб'єктивні характеристики всіх сфер життєдіяльності людини, серед яких економічна, соціальна, екологічна та суспільно-політична. Якість життя - це інтегральна якісна характеристика життя людей, яка розкриває по відношенню до суспільства в цілому критерії його життєдіяльності, умови життєзабезпечення, а також умови життєздатності суспільства як цілісного соціального організму.

\section{Список використаних джерел}

1. Геєць В. Новий прагматизм - інструмент досягнення кращого майбутнього [Текст] / В. Геєць // Економічна теорія. - 2017. - №1 . - С. $5-24$.

2. Гриценко А.А. Логіко-історичні засади кардинальних економічних змін і переходу до реконструктивного розвитку [Текст] / А.А. Гриценко // Економіка України. - 2017. - №5-6. - С. 39-55.

3. Чечель О.М. Базові критерії добробуту населення [Текст] / О.М. Чечель / Інвестиції: практика та досвід. - 2011. -№1. - С. 82-85.

4. Андрющенко О.Б. Державний механізм управління якістю життя населення України [Текст] : дис. ... канд. наук 3 держ.упр.: 25.00.02 / О. Б. Андрющенко. - Хмельницький, 2017. - 198 с.

Тетеринец Т.А., к. э. н., доцент, Белорусский государственный аграрный технический университет

\section{ПРОБЛЕМЫ РАЗВИТИЯ ЧЕЛОВЕЧЕСКОГО КАПИТАЛА В СЕЛЬСКОМ ХОЗЯЙСТВЕ БЕЛАРУСИ}

Экономическая эволюция белорусского общества в современных условиях движется в направлении активного вовлечения в общемировые глобализационные тенденции. Данные процессы затрагивают достаточно консервативную сферу отечественной экономики - сельское хозяйство. На протяжении длительного периода исторического времени аграрный сектор выступал органической частью не только народнохозяйственного, но и социально-культурного укладов отечественной экономики. Это обстоятельство стоит учитывать именно сегодня, когда речь идет о том, что основой 
экономического развития и процветания должна стать принципиально новая концепция развития, основанная на всемирном финансовом, информационном, производственном взаимодействии. В этой связи отечественная экономико-социальная структура должна получить существенный модернизационный импульс и продолжить свою трансформацию.

В последние годы, хотя и наметились положительные тенденции в развитии агропромышленного комплекса, однако в полной мере не обеспечивается эффективное развитие села. Сложившиеся структура аграрного производства и механизмы хозяйствования далеко не всегда способствуют рентабельному ведению отрасли даже при нормативном уровне затрат.

Важнейшим направлением повышения эффективности использования человеческого капитала сельскохозяйственной отрасли является совершенствование системы управления трудовыми ресурсами, определяющей их наличие и качественный состав, уровень образования и т.д. Качество менеджмента кадрового потенциала во многом предопределяет эффективность использования и других ресурсов аграрной сферы: земельных, материальных, финансовых, а значит, и успешность деятельности отрасли в целом и конкретного предприятия в частности.

Учитывая сложившуюся демографическую ситуацию, прирост данного элемента человеческого капитала весьма проблематичен. Особенно ярко это проявляется в сельском хозяйстве, где экстенсивные источники прироста трудовых ресурсов исчерпаны и их увеличение становится практически невозможным. Кроме того, для сельскохозяйственного труда характерны существенные отличия, связанные с особенностями аграрного производства. Экономический рост в аграрном секторе может обеспечиваться, прежде всего, на основе роста производительности труда. Факторная доля труда в валовом доходе сельскохозяйственных предприятий Республики Беларусь, являющаяся параметром производственной функции КоббаДугласа, составляет не менее 0,3 [1].

Проведение системного и комплексного анализа состава и структуры человеческого, оценка демографического потенциала в сельском хозяйстве Республике Беларусь позволили выявить следующие основные проблемы в этой сфере [2-4].

$\mathrm{B}$ аграрном секторе отмечается устойчивая динамика сокращения численности сельского населения. Несмотря на некоторое улучшение демографической ситуации в последние годы, в динамике ее развития сохраняются негативные тенденции. Основными индикаторами 
демографического неблагополучия являются естественная убыль населения и, как следствие, его сокращение, высокая смертность и старение белорусской нации, усиливающаяся территориальная неравномерность в формировании демографического потенциала. Удельный вес сельского населения в общей численности населения на протяжении 2010-2017 гг. сократился с 24,9 до 21,9\% [2].

Указанное обстоятельство провоцирует существенное снижение численности населения в трудоспособном возрасте, занятых в сельском хозяйстве: за исследуемый период падение количества основной части работоспособного населения составило 16,3\%. Данные обстоятельства способствовали тому, что коэффициент трудовой нагрузки в агарной сфере в 2010-2017 гг. увеличился с 1,8 до 2,0 [2].

В результате отмечается снижение списочной численности работников организаций в среднем за год в сельском хозяйстве на $20,9 \%$. Учитывая высокую трудоемкость работ в этой сфере, а также высокий удельный вес использования ручного труда, сложившаяся ситуация негативным образом сказывается на формировании трудового потенциала аграрной сферы [2].

Одной из серьезных проблем, формирующих рынок труда в сельскохозяйственной области, является уровень оплаты труда. Несмотря на некоторый рост заработной платы в настоящее время размер номинальной начисленной заработной платы в сельском хозяйстве составляет $65,8 \%$ к среднереспубликанскому уровню. При этом в исследуемом периоде темп роста реальной заработной платы в целом по республике существенно опережал аналогичный показатель в аграрной сфере [2].

Отсутствие развитой социальной инфраструктуры негативным образом сказывается на формировании трудового потенциала в сельском хозяйстве республики. Низкая обеспеченность жильем, сокращение количества учебных и воспитательных заведений различного тира, недостаточность или отсутствие объектов культурнобытового назначения, включая магазины шаговой доступности, являются одной из важнейших проблем развития сельских территорий и, соответственно, обеспечения аграрной сферы высокопрофессиональными работниками.

Инвестирование социальной сферы села в условиях ограниченных финансовых возможностей государства осуществляется по остаточному принципу. В результате различие в уровнях социальных стандартов города и деревни постоянно возрастает. Так, в 2017 г. инвестиции в сельское хозяйство составили 1069,7 млн. долл. США, составив 10,4\% от общего объема инвестиций в основной капитал [2]. 
Проблема села и сельскохозяйственного производства - одна из главных в социально-экономическом развитии общества и укреплении безопасности страны. Естественно, что развитие сельского хозяйства на всех уровнях необходимо осуществлять с системных (комплексных) позиций, отказавшись от чисто рыночных, социальноориентированных, экологических и прочих узко ориентированных позиций. При всей важности экономической составляющей, она должна быть приведена к единому знаменателю с вопросами социальной трансформации, социализированности сельского населения, институционализации.

\section{Список литературных источников}

1. Тетеринец, Т.А. Инвестиционный и человеческий капитал АПК: единство и борьба противоречий // сборник трудов III Международной научно-практической конференции «Экономикоматематические методы анализа деятельности предприятий АПК», под ред. С.И. Ткачева.- Саратов: Саратовский государственный университет имени Н.И. Вавилова.- Амирит.- 2019.- С. 338-341.

2. Сборник Сельское хозяйство Республики Беларусь, 2018 // Национальный статистический комитет Республики Беларусь, редкол. И.В. Медведева [и др.].: Минск.- 2018-234 с.

3. Tsetsiatynets, T., \& Chizh, D. (2018). Public-Private Partnership as the Innovative Instrument of Effective Management of Belarusian AgroIndustrial Complex. Marketing and Management of Innovations, 4, 54-65.

4. Тетеринец, Т.А. Инвестиции в человеческий капитал как фактор формирования инновационной экономики // Економічний вісник університету: Збірник наукових праць учених та аспірантів. Випуск 41. - Переяслав-Хмельницький: ДВНЗ «ПереяславХмельницький державний педагогічний університет імені Григорія Сковороди», 2019. - С. 75-82. 
Тищенко О. П.,

д. е. н., ст. н. с., Київський національний економічний університет імені Вадима Гетьмана

\section{ДИСБАЛАНСИ ІНКЛЮЗИВНОГО РОЗВИТКУ ЕКОНОМІКИ УКРАЇНИ: ОЦІНАА ТА ШЛЯХИ ПОДОЛАННЯ}

Характерною тенденцією трансформаційних процесів в національній економіці України, що відбуваються останніми роками, стало зміцнення провідних позицій агропродовольчого сектору та зростання його ролі й впливу на макроекономічну динаміку усіх базових показників соціально-економічного розвитку держави.

Так, лише за п'ять звітних років (2012-2017 рр.) приріст частки сільського, лісового та рибного господарства у загальному обсязі валової доданої вартості по країні склав $3,1 \%$, що є найвищим показником порівняно з іншими видами діяльності. Протягом чотирьох років поспіль у цій сфері щорічно створювалось 12-14\% сукупної валової доданої вартості, що забезпечило їй стабільну третю позицію після оптової та роздрібної торгівлі, ремонту автотранспортних засобів і мотоциклів та переробної промисловості. При цьому слід також взяти до уваги, що в обсязі валової доданої вартості, що іiі створено у переробній промисловості, достатньо вагома частина припадає на виробництво харчових продуктів, напоїв і тютюнових виробів, яке $\epsilon$ однією із складових частин агропромислового сектору національної економіки (табл.).

Кількість зайнятих у сільському, лісовому та рибному господарстві у періоді, що розглядається, не зазнала значних змін. У 2017 р. вона становила близько 2,9 млн. осіб, або 17,7\% від загальної кількості зайнятих в країні, що на 2,6 процентних пункти перевищило аналогічний показник по промисловості [1, с. 20 ].

Найбільш переконливо про роль агропромислового комплексу у національній економіці у теперішній час свідчить товарна структура експорту. Так, частка позицій, згідно УКТЗЕД, за кодами 1-24 (продукти тваринного, рослинного походження та готові харчові продукти) у загальному обсязі експорту країни зросла з 26,0\% у 2012 році до 41,0\% у 2017-му [2, с. $252 ; 3$, с. 395].

Але, якщо розглядати динаміку розвитку агропродовольчого сектору держави через призму положень концепції інклюзивного зростання, яка просуває справедливі можливості економічних 
учасників під час економічного зростання 3 вигодами для кожного сектору суспільства, рівний доступ до ключових ресурсів, розподілу

Таблиця
Частка валової доданої вартості та середньомісячна номінальна заробітна плата штатних працівників по Україні та у розрізі окремих видів економічної діяльності

\begin{tabular}{|c|c|c|c|c|c|}
\hline & \multicolumn{3}{|c|}{$\begin{array}{c}\text { Частка валової } \\
\text { доданої вартості, \% }\end{array}$} & \multirow{2}{*}{\multicolumn{2}{|c|}{$\begin{array}{c}\text { Середньомісячна } \\
\text { номінальна } \\
\text { заробітна плата } \\
\text { штатних } \\
\text { працівників } \\
2017 \\
\end{array}$}} \\
\hline & & & & & \\
\hline & 2012 & 2017 & $\begin{array}{l}\text { Зміна } \\
(+,-)\end{array}$ & грн. & $\begin{array}{c}\% \text { до } \\
\begin{array}{c}\text { середньої по } \\
\text { країні }\end{array} \\
\end{array}$ \\
\hline Україна - усього & 100,0 & 100,0 & $\mathbf{x}$ & 7104 & 100,0 \\
\hline $\begin{array}{l}\text { Оптова та роздрібна торгівля, } \\
\text { ремонт автотранспортних } \\
\text { засобів і мотоциклів }\end{array}$ & 16,7 & 16,3 & $-0,4$ & 7631 & 107,4 \\
\hline Переробна промисловість & 14,1 & 14,3 & $+0,2$ & 7299 & 102,7 \\
\hline $\begin{array}{l}\text { у.т.ч. виробництво харчових } \\
\text { продуктів, напоїв і тютюнових } \\
\text { виробів }\end{array}$ & 3,7 & $4,5^{*}$ & $+0,8$ & 6756 & 95,1 \\
\hline $\begin{array}{l}\text { Сільське, лісове та рибне } \\
\text { господарство }\end{array}$ & 9,0 & 12,1 & $+3,1$ & 6057 & 85,3 \\
\hline У т.ч. сільське господарство & $\mathrm{x}$ & $\mathrm{x}$ & $\mathrm{x}$ & 5761 & 81,1 \\
\hline $\begin{array}{l}\text { Транспорт, складське } \\
\text { господарство, поштова та } \\
\text { кур`єрська діяльність }\end{array}$ & 8,2 & 7,6 & $-0,6$ & 7688 & 108,2 \\
\hline Операції з нерухомим майном & 6,9 & 6,8 & $-0,1$ & 5947 & 83,7 \\
\hline $\begin{array}{l}\text { Добувна промисловість та } \\
\text { розроблення кар`єрів }\end{array}$ & 6,5 & 7,0 & $+0,5$ & 9704 & 136,6 \\
\hline Освіта & 6,0 & 5,3 & $-0,7$ & 5857 & 82,4 \\
\hline $\begin{array}{l}\text { Державне управління й } \\
\text { оборона, обов 'язкове соціальне } \\
\text { страхування }\end{array}$ & 5,1 & 6,5 & $+1,4$ & 9372 & 131,9 \\
\hline $\begin{array}{l}\text { Фінансова та страхова } \\
\text { діяльність }\end{array}$ & 5,0 & 3,2 & $-1,8$ & 12865 & 181,1 \\
\hline $\begin{array}{l}\text { Охорона здоров я та надання } \\
\text { соціальної допомоги }\end{array}$ & 4,2 & 3,0 & $-1,2$ & 4977 & 70,1 \\
\hline
\end{tabular}


доходу та багатства [6, с. 58], то не можна не помітити його суттєвого відставання від інших секторів національної економіки. Підтвердженням цьому $є$ значно нижчий рівень заробітної плати штатних працівників, яка у 2017 р. становила: у сільському господарстві - близько 80\% від іiі середнього рівня по країні, а у виробництві харчових продуктів, напоїв та тютюнових виробів - 95\% (табл.).

Наявні статистичні дані щодо обсягу та структури грошових доходів домогосподарств також свідчать про їх відставання у сільській місцевості порівняно з міськими поселеннями. Так, наприклад, у 2017 році грошові доходи у середньому за місяць у розрахунку на одне домогосподарство в міських поселеннях складали 7443,0 грн., а у сільській місцевості - лише 6535,6 грн., тобто були меншими майже на $14 \%$. Головною причиною такого відставання є значно нижча частка саме оплати праці в загальному обсязі грошових доходів, яка у сільській місцевості становила 48,6\%, а у міських поселеннях - 64,6\% [3, c. 94].

Набагато гіршими є й можливості доступу жителів сільської місцевості до базових соціальних благ. Згідно офіційних даних Державної служби статистики України, станом на 1 січня 2018 року, питома вага обладнаної загальної площі житлових приміщень у житлових будинках, гуртожитках та нежитлових будівлях у сільській місцевості становила: водопроводом - 36,6\%, каналізацією - 33,0\%, гарячим водопостачанням - 24,0\%, природним газом - 57,3\%, центральним опаленням - усього $1,3 \%$ [7, с. 52]. Для порівняння зазначимо, що у міських поселеннях частка житла, обладнаного зазначеними послугами $є$ значно вищою: по водопроводу - у 2,1 рази (обладнано 78,0\%), по каналізації - у 2,3 (77,0\%), по гарячому водопостачанню - у 2,6 (62,7\%), по природному газу - в 1,4 рази $(82,2 \%)[7$, c. 51$]$.

Крім того, результати аналізу у територіальному розрізі свідчать, що у деяких провідних за рівнем розвитку агропродовольчого сектору регіонах, зокрема у Вінницькій, Кіровоградській, Хмельницькій областях, обладнання житлового фонду у сільській місцевості відповідними послугами суттєво відстає навіть від зазначених вище середніх показників в цілому по країні.

Результати оцінки розвитку національної економіки 3 позицій «інклюзивного підходу» повністю підтверджують думку вітчизняних науковців щодо суперечності, в окремих випадках, процесу економічного зростання, коли більшість населення не відчуває покращення життя або воно є не зіставним зі збагаченням невеликої 
групи людей [8]. Також не можна не погодитись 3 думкою авторів щодо того, що саме концепція інклюзивного зростання, на відміну від стандартного економічного зростання, зміщує акцент на розвиток людини, зростання ії добробуту, зниження рівня бідності й нерівності.

Отже, наявні диспропорції між «внеском» агропродовольчого сектору в економічний розвиток країни в сучасних умовах, рівнем й якістю життя його працівників та домогосподарств, що проживають у сільській місцевості, можливостями доступу до економічних та соціальних благ, задоволення матеріальних й духовних потреб, з точки зору «інклюзивного підходу» $є$ достатньо вагомими і мають стати об'єктом цілеспрямованої державної політики з метою їх зменшення та вирівнювання умов життя в масштабах усієї країни.

Практична реалізація принципів концепції інклюзивного зростання щодо агропродовольчого сектору, який нині відіграє провідну роль у розвитку національної економіки, потребує реалізації низки заходів, які, на нашу думку, сприятимуть, 3 одного боку, підвищенню рівня віддачі його потенціалу та, відповідно, зростанню конкурентоспроможності вітчизняної економіки на світовому ринку сільськогосподарської продукції та готових харчових продуктів, а 3 іншого - дозволять суттєво покращити стандарти життя як зайнятих у ньому працівників, так й безпосередньо усіх домогосподарств у сільській місцевості. Першочергові заходи мають бути спрямовані на:

визнання, законодавче закріплення пріоритетності агропродовольчого сектору у загальнодержавній економічній політиці та його реальну підтримку з боку державних інституцій;

підвищення інвестиційної привабливості агропродовольчої сфери України, у тому числі для іноземних інвесторів;

державну підтримку та стимулювання виходу вітчизняних підприємств агропродовольчого сектору на світовий ринок продукції сільського господарства та продовольства;

здійснення адресної преференційної політики для виробників сільськогосподарської продукції кінцевого споживання, у першу чергу для експортоорієнтованих підприємств;

зростання оплати праці в агропродовольчому секторі до рівня, не нижче середнього у державі, 3 подальшим його поступовим підвищенням відповідно до обсягів генерованих доходів;

розвиток системи пільгового кредитування підприємств, орієнтованих на використання інноваційних технологій при виробництві кінцевої продукції; 
збільшення обсягів фінансування розвитку мережі закладів соціальної сфери у сільській місцевості, у тому числі за рахунок коштів державного та місцевих бюджетів;

реалізацію цільових програм розвитку інфраструктури, насамперед шляхів сполучення (автомобільних, залізничних, водних) у сільській місцевості;

удосконалення організаційних та фінансово-економічних інструментів стимулювання діяльності об’єднаних територіальних громад щодо створення повноцінного і комфортного середовища на підвідомчих територіях, підвищення соціальних стандартів та надання високоякісних публічних послуг за різними напрямами життєдіяльності населення.

Послідовна реалізація, за допомогою дієвих механізмів, державної політики, спрямованої на інклюзивний розвиток та підтримку агропродовольчого сектору, як важливої складової єдиного господарського комплексу країни, нині є, по суті, безальтернативним шляхом забезпечення та утримання національної економіки на траєкторії економічного зростання в умовах сучасних глобальних трансформацій та викликів.

\section{Список використаних джерел}

1. Статистичний збірник «Сільське господарство України за 2017 рік» / відп. за випуск О.М. Прокопенко // Офіційний сайт Державної служби статистики України. URL: http://www.ukrstat.gov.ua/.

2. Статистичний щорічник України за 2012 рік / за ред. О.Г. Осауленка // Офіційний сайт Державної служби статистики України. URL: http://www.ukrstat.gov.ua/.

3. Статистичний щорічник України за 2017 рік / за ред. I.Є. Вернера // Офіційний сайт Державної служби статистики України. URL: http://www.ukrstat.gov.ua/.

4. Статистичний збірник «Валовий регіональний продукт за 2012 рік» / за ред. I.M. Нікітіної // Офіційний сайт Державної служби статистики України. URL: http://www.ukrstat.gov.ua/.

5. Статистичний збірник «Валовий регіональний продукт у 2017 році» / за ред. I.М. Нікітіної // Офіційний сайт Державної служби статистики України. URL: http://www.ukrstat.gov.ua/.

6. Бобух I.M., Щегель С.М. Стратегічні орієнтири економічного зростання України: інклюзивність як ключовий пріоритет. Вісник НАН України. 2018. № 7. С. 55-70. 
7. Статистичний збірник «Житловий фонд України» / відп. за випуск О.О. Кармазіна // Офіційний сайт Державної служби статистики України. URL: http://www.ukrstat.gov.ua/.

8. Малий І.Й., Смельяненко Л.М., Дзензелюк К.В. Імплементація концепції інклюзивного розвитку в практику регулювання зайнятості населення. Ефективна економіка. 2018. № 12. - URL: http://www.economy.nayka.com.ua/?op=1\&z=6776.

Феняк Л.А.

Вінницький національний аграрний університет

\section{СУЧАСНІ ТЕНДЕНЦЇ̈ РОЗВИТКУ ПІДПРИСМСТВ ГАЛУЗІ САДІВНИЦТВА У ВІННИЦЬКІЙ ОБЛАСТІ}

3 огляду на особливості та тенденції сучасних змін у розвитку промислового садівництва, дослідження комплексу питань щодо підвищення ефективності функціонування галузі, пошук шляхів подальшого зростання обсягів виробництва плодів та ягід, нарощування експортного потенціалу набувають виняткової актуальності.

Нині найгострішою в сучасному промисловому садівництві країни $є$ проблема визначення сукупності чинників ефективного функціонування галузі, їх ролі та значення у виробничому процесі. Адже виробництво високоякісної плодоягідної продукції має стати одним 3 пріоритетних напрямів розвитку сільського господарства, зважаючи на сукупність чинників, що лежать в основі успішного ведення садівництва.

Вінницька область традиційно займає провідне місце серед регіонів України по виробництву продукції садівництва, іiї переробки та вирощування посадкового матеріалу. Сприятливі природні умови, наявність мережі великих плодопереробних підприємств, значна місткість внутрішнього ринку плодів, ягід і продуктів їх промислової переробки та наявний експортний потенціал виробництва цієї продукції $\epsilon$ важливими передумовами невпинного поступу промислового садівництва у Вінницькій області [1].

За площею сільськогосподарських угідь Вінницька область посідає 6-те місце серед регіонів України, але займає 1-ше місце за площею плодоягідних насаджень у плодоносному віці, яка складає 22,8 
тис. га станом на 1 січня 2018 року. Питома вага плодоягідних насаджень у структурі посівних площ у Вінницькій області складає $1,3 \%$, що у 2,6 рази більше середнього показника по Україні, який становить лише $0,49 \%$ (табл. 1 ).

У 2017 році валовий збір плодів і ягід склав 233,7 тис. т, що є найбільшим показником по Україні. Щодо урожайності, то 2017 рік не був сприятливим за своїми погодними умовами напередодні збирання врожаю, коли велика його частка була пошкоджена, але традиційно цей показник є вищим за середній по країні. Вінницька область має значно кращі показники за обсягами виробництва та споживання плодів і ягід на одну особу.

Таблиця 1

\section{Показники виробництва та споживання плодів і ягід в Україні та Вінницькій області, 2017 р. [2]}

\begin{tabular}{|l|c|c|}
\hline \multicolumn{1}{|c|}{ Показники } & Україна $^{1}$ & Вінницька область \\
\hline $\begin{array}{l}\text { Площа сільськогосподарських угідь, } \\
\text { тис. га }\end{array}$ & 41489,3 & 2014,2 \\
\hline $\begin{array}{l}\text { Площа плодоягідних насаджень у } \\
\text { плодоносному віці, тис. га }\end{array}$ & 198,5 & 22,8 \\
\hline $\begin{array}{l}\text { Питома вага плодоягідних насаджень } \\
\text { у загальній площі } \\
\text { сільськогосподарських угідь, \% }\end{array}$ & 0,49 & 233,7 \\
\hline Валовий збір плодів і ягід, тис.т & 2048 & 102,5 \\
\hline Урожайність, ц/га & 103,1 & 148 \\
\hline $\begin{array}{l}\text { Виробництво плодів і ягід на одну } \\
\text { особу, кг }\end{array}$ & 48 & 58,2 \\
\hline $\begin{array}{l}\text { Споживання плодів та ягід на одну } \\
\text { особу, кг }\end{array}$ & 52,8 & Автоно \\
\hline
\end{tabular}

${ }^{1}$ без урахування тимчасово окупованої території Автономної Республіки Крим, м.Севастополя та частини зони проведення антитерористичної операції.

Галузь садівництва Вінницької області постійно нарощує свій потенціал. Із року в рік зростають площі насаджень та обсяги виробництва плодово-ягідної продукції. За останні чотири роки обсяги виробництва нарощено майже на $20 \%$ (табл.2). Рівень урожайності плодоносних культур поступово зростає, що пов'язано, перш за все, із застосуванням новітніх технологій у виробництві плодів і ягід, із підвищенням рівня інтенсифікації галузі. Це пояснюється не тільки виключно сприятливими природно-кліматичними умовами, але й функціонуванням у регіоні великої мережі спеціалізованих садівничих підприємств. 
Таблиця 2.

Динаміка площ, урожайності і валових зборів плодів та ягід у Вінницькій області [3]

\begin{tabular}{|c|c|c|c|c|}
\hline \multirow[b]{2}{*}{ Роки } & \multicolumn{2}{|c|}{$\begin{array}{c}\text { Площа плодоягідних } \\
\text { насаджень, тис. га }\end{array}$} & \multirow{2}{*}{$\begin{array}{c}\text { Урожайність } 3 \\
1 \text { га насаджень, } \\
\text { ц }\end{array}$} & \multirow{2}{*}{$\begin{array}{c}\text { Валовий } \\
\text { збір, тис. ц }\end{array}$} \\
\hline & всього & $\begin{array}{c}\text { у тому числі у } \\
\text { плодоносному } \\
\text { віці }\end{array}$ & & \\
\hline 1995 & 68,5 & 54,3 & 26,0 & 1417,3 \\
\hline 2000 & 35,4 & 31,5 & 23,2 & 728,7 \\
\hline 2005 & 24,2 & 21,9 & 84,4 & 1849,2 \\
\hline 2010 & 24,9 & 21,7 & 87,1 & 1892,4 \\
\hline 2012 & 26,1 & 22,7 & 109,7 & 2521,9 \\
\hline 2013 & 26,8 & 23,1 & 119,2 & 2754,3 \\
\hline 2014 & 26,8 & 23,8 & 101,9 & 2420,7 \\
\hline 2015 & 27,5 & 24,1 & 121,5 & 2922,8 \\
\hline 2016 & 27,6 & 24,2 & 121,1 & 2695,4 \\
\hline 2017 & 26,7 & 22,8 & 102,5 & 2337,3 \\
\hline
\end{tabular}

За останні 5 років загальна площа плодоягідних насаджень зросла на $10 \%$, площа насаджень у плодоносному віці - на $11 \%$, в той час як в середньому по Україні ці показники за аналогічний період дещо зменшились. Протягом останніх 10 років область є лідером за площею посадки молодих інтенсивних садів. За цим показником область вийшла на європейські норми. Лише за період 2015-2018 років закладено молоді високо інтенсивні сади на площі понад 3,5 тис. га. В 2019 році в області планується висадити 500 га молодих садів.

Області вдалося зберегти координуючу структуру, яка $\epsilon$ організаційним штабом для садівників. Це $\epsilon$ корпорація «Вінницясадвинпром», господарства якої виробляють щонайменше чверть яблук від валового їх збору в організованому секторі економіки держави. У господарствах, що входять до корпорації є майже 4 тис. га молодих інтенсивних садів, що становить $30 \%$ від загальної їх площі.

За даними Корпорації «Вінницясадвинпром», свою діяльність в галузі садівництва та ягідництва здійснює близько 100 підприємств та фермерських господарств, що виробили в 2018 році 324 тисяч тонн продукції i, на яких працює понад 10 тисяч чоловік. Наявність у регіоні потужних переробних підприємств, - таких, як «Аграна Фрут Україна», «Пфанер Бар», «Яблуневий дар», Консервний завод «Поповецький», «Вінні Фрут», Консервний завод в с. Рахни Лісові («Вітмарк Україна»), 
- дає можливість виробникам фруктів та ягід зменшити витрати на транспортування, зберігання продукції тощо. [4]

Вінницька область $є$ флагманом садівництва, який виробляє найбільшу кількість плодоягідної продукції в країні. Для підвищення ефективності використання промислового потенціалу галузі садівництва необхідне поєднання організаційно-економічних чинників. Напрямками покращення економічної ситуації в галузі $\epsilon$ краще використання наявних ресурсів господарств завдяки впровадженню інтенсивних ресурсозберігаючих технологій вирощування плодоягідних культур, поліпшенню їх породного й сортового складу, розширенню переробки і зберігання продукції.

\section{Список використаних джерел}

1. Єрмаков, О. Ю. Ефективність інвестицій у садівництво: монографія / О. Ю. Єрмаков, М. І. Кісіль, В. І. Чорнодон. - Т.: Крок, 2011. - 233 c.

2. Офіційний сайт державної служби статистики України [Електронний ресурс]- Режим доступу: http://www.ukrstat.gov.ua/

3. Вінниччина у цифрах у 2017 році: стат. зб. / [за ред. С. Н. Ігнатова]; Держ. служба статистики України, Голов. упр. статистики у Вінниц. обл. - Вінниця, 2018.

4. Феняк Л.А. Напрямки підвищення ефективності використання промислового потенціалу галузі садівництва у вінницькій області /Л.А. Феняк //Агросвіт. - 2016 р. - №11.-С.63-69

Хаєцька О.П., к.е.н., доцент Вінницький національний аграрний університет

\section{ЕКОНОМІЧНЕ ЗРОСТАННЯ В УКРАЇНI}

В останні роки економіка України демонструє нестійку динаміку щодо економічного зростання, спостерігається зниження рівня інвестиційно-інноваційної привабливості та конкурентоспроможності, різні галузі по різному адаптовані до викликів сучасності.

Основним показником розвитку і добробуту будь-якої країни $\epsilon$ економічне зростання, це одна з головних макроекономічних цілей, 
досягнення якої обумовлено необхідністю випереджаючого зростання національного доходу порівняно з ростом чисельності населення на фоні підвищення рівня життя в країні $[1$, с. 85].

Економічне зростання показує збільшення обсягів виробництва товарів і послуг (збільшення реального ВВП), яке може збільшуватися у такі способи: на умовах збільшення потенційного ВВП та на умовах усунення рецесійного розриву (розрив між сукупним попитом i потенційним ВВП).

До факторів, які визначають динаміку економічного зростання належать: кількість і якість трудових ресурсів; кількість і якість природних ресурсів; капіталовкладення або інвестиції, з урахуванням технічного рівня засобів виробництва, який забезпечується науковотехнічним прогресом; підприємницькі здібності.

Економічне зростання відображується: у збільшенні реального ВВП (ЧВП або НД) в абсолютних вимірниках за певний проміжок часу; в розрахунку на душу населення; в розрахунку на одного зайнятого [2, c. 471].

Економіка, яка стабільно розвивається не унікальне явище, але карта успішних економік світу щорічно зазнає якихось змін. Для того щоб відобразити реальні зміни в економіці визначають річні темпами зростання (табл. 1).

Лідери економічного зростання у світі у 2018 році були: Сирія, Бангладеш, Бутан, Індія, Руанда. Низькі показники економічного зростання спостерігались у країнах: Венесуела, Ємен, Іран, Екваторіальна Гвінея, Аргентина.

За прогнозами $\mathrm{PwC}$ «Світ у 2050 році»: найбільшою економікою до 2030 року стане Китай, темпи зростання якого виявляться на рівні загальносвітових; значних темпів розвитку досягнуть Бразилія, Росія, Польща; Індія може посперечається з США за друге місце; Індонезія, Мексика і Нігерія, можливо, витіснять Великобританію і Францію 3 першої десятки; значно поліпшить свої позиції в рейтингу Філіппіни, В'єтнам і Малайзія [3].

Таблиця 1

Темпи економічного зростання за групами країн

\begin{tabular}{|l|c|c|c|c|c|}
\hline & 2014 & 2015 & 2016 & 2017 & 2018 \\
\hline Весь світ & 3,6 & 3,9 & 3,4 & 3,5 & 3,6 \\
\hline Розвинені країни & 1,3 & 2,2 & 1,6 & 2,2 & 2,0 \\
\hline США & 3,0 & 2,9 & 1,5 & 2,2 & 2,0 \\
\hline Сврозона & 0,9 & 2,2 & 1,9 & 2,2 & 2,1 \\
\hline
\end{tabular}




\begin{tabular}{|l|c|c|c|c|c|}
\hline $\begin{array}{l}\text { Центральна і східна } \\
\text { Свропа }\end{array}$ & 1,8 & 2,0 & 2,9 & 2,5 & 3,3 \\
\hline Країни СНД & 1,3 & 2,3 & 2,3 & 2,5 & 2,6 \\
\hline Африка & 2,5 & 3,1 & 1,7 & 3,0 & 3,5 \\
\hline $\begin{array}{l}\text { Східна і Південна } \\
\text { Азія }\end{array}$ & 6,5 & 6,0 & 6,0 & 5,8 & 5,9 \\
\hline Індія & 7,2 & 7,6 & 7,1 & 6,7 & 7,2 \\
\hline Китай & 7,0 & 6,9 & 6,7 & 6,8 & 6,5 \\
\hline Україна & $-5,5$ & $-9,0$ & 1,0 & 1,3 & 3,0 \\
\hline
\end{tabular}

*Джерело: [4]

Економічне зростання України у 2018 році становило $3 \%$, українська економіка досягла в поточному році таких результатів завдяки: аграрній галузі (висока урожайність деяких культур, ранній збір); покращенню виробництва металургійної галузі; підвищенню внутрішнього споживання; збільшенню переказів заробітчан, які згодом витрачали свої гроші в Україні; підвищенню зарплат та пенсій. У той же час, спостерігаються і негативні тенденції, які з року в рік «тягнуть» Україну на дно: скорочення інвестицій, затримки реалізації структурних реформ та виконання програми МВФ, потреба у зовнішньому фінансуванні [5].

За відсутності прогресу в реалізації реформ, невиконання умов програми співпраці з МВФ призведуть до подальшої втрати інвесторів, загострення макроекономічної вразливості та скорочення внутрішнього попиту. Також Україна у 2019 та 2020 роках потребуватиме значних фінансових ресурсів для погашення державного боргу.

Станом на 2018 рік ВВП України на душу населення становить 2,82 тис доларів, країн, що розвиваються - 5,49 тис доларів, середній по світу - 11,73 тис доларів, розвинених країн - 48,97 тис доларів.

Згідно з прогнозом МВФ, у 2023 році ці показники становитимуть 4,22 тис доларів - для України (зростання 50\%), 7,43 тис доларів - для країн, що розвиваються (зростання 35\%), 14,49 тис доларів - середній по світу (зростання 24\%), 58,46 тис доларів - для розвинених країн (зростання 19\%) [6].

Позиції лідера у сфері стабільного економічного розвитку утримують Сполучені Штати Америки, завдяки чіткій та злагодженій роботі банківської системи, розвитку сільського господарства та промислового виробництва. 
На другому місці знаходиться Китай, майже кожен житель світу користується автомобілями, технікою, одягом, іграшками виробленими в Китаї [6].

Японія займає третю сходинку в рейтингу країн 3 високими темпами розвитку, завдяки злагодженій роботі уряду та великих підприємств. В країні застосовується політика, яка стимулює пропозицію якісної продукції, передбачає низький рівень оподаткування, підтримує міцну банківську систему та застосовує унікальну політику працевлаштування, вкладаються кошти в науку, робототехніку.

Значні результати економічного зростання прослідковуються у Німеччині - вдалі економічні реформи, що торкнулися сфери промисловості та торгівлі, збільшується експорт, підтримується високий рівень виробництва якісного товару. Стабільно розвивається економіка Великобританії - високий рівень промислового виробництва, експорт товару, розвиток науки, техніки, сфери страхування та фінансування. Також успішною країною вважається Франція, яка вдало поєднує розвиток сільського господарства, його експорт та вкладає інвестиції в розвиток гірничодобувної, машинобудівної, суднобудівної авіакосмічної промисловості [7].

В останні роки значного розвитку досягнула Індія, завдяки розвитку сільського господарства та гірничодобувної та обробної промисловості, за рахунок розвитку даних галузей значна частина населення забезпечена робочими місцями.

Крім перерахованих вище країн стабільне економічне зростання спостерігається у Бразилії та Канаді.

Якщо аналізувати за рахунок чого відбулось економічне зростання в Україні у 2017-2018 роках, то по-перше це стабільний розвиток сільськогосподарського виробництва та експорт аграрної продукції, по-друге, стабілізувалось виробництво у галузях літакобудування та кораблебудування, крім зазначених галузей вагому частку виробництва у структурі ВВП займає: мобільний зв'язок, мікроелектроніка та інформатика. По-трете, багато іноземних підприємств переносять своє виробництво в Україну, що збільшує зайнятість населення.

Але $\epsilon$ ряд причин, які стримують вітчизняний розвиток $\mathrm{i}$ відповідно економічне зростання: витрати на дослідження і розробку у різних галузях не значні, інноваційний клімат нестабільний; відсутність інноваційної структури, не завжди професійна кадрова політика та ін. [7]. 
Для прискорення економічного зростання в Україні пріоритетними напрямами $\epsilon$ : збереження макроекономічної стабільності, ефективна діяльність держави щодо обороноздатності країни, оздоровлення фінансового сектора, стимулювання та нарощування інвестицій, збереження частки стратегічно важливих підприємств, оновлення та індустріалізація економіки, проведення реформи державних підприємств, завершення реформи стосовно створення ринку землі. Ці реформи симулюватимуть розвиток вітчизняної економіки.

\section{Список використаних джерел}

1. Сталий розвиток суспільства: навчальний посібник / авт.: А. Садовенко, Л. Масловська, В. Середа, Т. Тимочко. - 2 вид. - К.; 2011. $-392 \mathrm{c}$.

2. Мікроекономіка і макроекономіка: Підручник для студентів екон. спец. зал. освіти: у 2 ч. / С.Будаговська, О. Кілієвич, І. Луніна та ін.; За заг. ред. С. Будаговської.. - К.: Вид-во Соломії Павличко «Основи», 2007. - 517с.

3. PwC: Економічний прогноз «Світ у 2050 році» / РwC Україна. URL: $\quad$ https://www.pwc.com/ua/uk/press-room/2015/the-world-in2050.html7. Фінансові кити: 10 країн, що впливають на економіку планети в 2018 URL: https://marketer.ua/ua/world-economy-2018/

4. World Economic Situation and Prospects 2018. The United Nations World Tourism Organization (UNWTO) also contributed to the report. URL: https://www.un.org/development/desa/dpad/wp-content/uploads/ sites /45/publication/WESP2018__Full_Web-1.pdf

5. Економічне зростання залежить від прогресу у впровадженні реформ та зовнішнього фінансування / Світовий банк. URL: https://www.worldbank.org/uk/news/press-release/2018/10/04/ukraineeconomic-update-october-2018

6. Якою буде економіка України через 5 років - прогноз МВФ URL:https://www.epravda.com.ua/news/2018/09/19/640725/

7. Сучасний стан економічної сфери в Україні URL: https://uamodna.com/articles/suchasnyy-stan-ekonomichnoyi-sfery-vukrayini/ 


\section{ПОЛІТИЧНІ ДЕТЕРМІНАНТИ РОЗВИТКУ МІЖНАРОДНОГО ТУРИЗМУ}

Уряди країни, в яких туризм посідає провідне місце в системі національних пріоритетів, велику увагу приділяють питанням, пов'язаним 3 виявленням позитивних i негативних факторів, що можуть чинити вплив на розвиток туристичної галузі, та розробкою відповідних заходів, спрямованих або на пом'якшення їх дії, або на використання додаткових можливостей, які вони відкривають.

Досвід останніх десятиріч наочно доводить, що одну з ключових ролей серед детермінантів розвитку туризму як на національному, так i на міжнародному рівні відіграють політичні фактори, які прямо або опосередковано формують базові параметри ведення туристичної діяльності, і як наслідок, стимулюють або стримують міжнародні туристичні потоки (табл. 1).

Таблиия 1

Вплив політичних факторів на умови розвитку міжнародного туризму

\begin{tabular}{|c|c|c|c|}
\hline & \multicolumn{2}{|c|}{ Наслідки впливу } \\
\hline & & позитивні & негативні \\
\hline \multirow{2}{*}{ } & 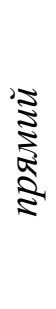 & $\begin{array}{l}\text { 1. Сукупність політичних дій та } \\
\text { рішень, спрямованих на } \\
\text { покращення умов ведення } \\
\text { туристичної діяльності та } \\
\text { стимулювання міжнародних } \\
\text { туристичних потоків }\end{array}$ & $\begin{array}{l}\text { 2. Сукупність політичних дій та } \\
\text { рішень, спрямованих на } \\
\text { ускладнення умов ведення } \\
\text { туристичної діяльності та } \\
\text { обмеження міжнародних } \\
\text { туристичних потоків }\end{array}$ \\
\hline & 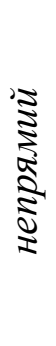 & $\begin{array}{l}\text { 3. Сукупність політичних дій, } \\
\text { рішень та обставин загального } \\
\text { характеру, що опосередковано } \\
\text { сприяють покращенню умов } \\
\text { ведення туристичної діяльності та } \\
\text { активізації міжнародних } \\
\text { туристичних потоків }\end{array}$ & $\begin{array}{c}\text { 4. Сукупність політичних дій, } \\
\text { рішень та обставин загального } \\
\text { характеру, що опосередковано } \\
\text { погіршують умови ведення } \\
\text { туристичної діяльності та } \\
\text { стримують міжнародні туристичні } \\
\text { потоки }\end{array}$ \\
\hline
\end{tabular}

Кожен з квадрантів наведеної матриці детермінант політичного впливу на міжнародний туризм має принципово різні характеристики i формати прояву, але разом з тим спирається на численні реальні 
приклади реалізації у новітній історії.

1. Фактори прямого позитивного впливу. Йдеться перш за все про правові основи здійснення туристичної діяльності, які визначаються системою міждержавних угод, а також нормативних і програмних документів, прийнятих різноманітними міжнародними $(\mathrm{OOH}$, ЮНВТО, IATA, ГАТТ та ін.) та національними організаціями.

У регулюванні розвитку туризму більшість держав керуються сьогодні Гаазькими (1989 р., Гаага, Нідерланди) та Манільськими (1980 р., Маніла, Філіппіни) угодами, рекомендаціями Осакської конференції міністрів по туризму (1994р., м. Осака, Японія), прийнятою на 6-й сесії Генеральної Асамблеї ВТО «Хартією туризму», Сеульською декларацією «Світ і туризм» (м. Сеул, Республіка Корея, 2001 р.) та ін.

Поза тим, у деяких країнах створені високоорганізовані та всеохоплюючі національні туристичні правові системи. Показовим у цьому сенсі $є$ приклад Японії, де на підтримку перспективних починань в сфері туризму прийнято закони про розвиток, про поліпшення оснащення міжнародних туристичних готелів, про національні парки, про гарячі джерела, про діяльність гіда-перекладача, про розвиток туризму через традиційні свята та ін. На потужній нормативноправовій базі, яка містить у собі закони щодо діяльності туристичних компаній, готелів, гідів-екскурсоводів, інвестування, підготовки кадрів, регулювання діяльності на туристичному ринку, обмеження негативного впливу туризму та захисту моралі суспільства тощо, грунтується динамічний розвиток і єгипетської туристичної галузі.

2. Фактори прямого негативного впливу. Міжнародний туризм нерідко постає інструментом досягнення різноманітних політичних цілей на світовій арені. Окрім формування громадської думки стосовно безпеки та привабливості дестинацій, політичні рішення безпосереднім чином впливають на індустрію туризму.

На перший погляд скорочення майже на $30 \%$ в’їзного туристичного потоку до Туреччини у 2016 році [1; 2] стало прямим i виключним наслідком військових конфліктів, терористичних актів та політичних хвилювань на Близькому Сході. Високий рівень кореляції між цими подіями, обумовлений занепокоєнням іноземних туристів, $\mathrm{i}$ справді видається природним. Проте зрозуміло, що у реальності відпочинок на турецькому узбережжі є не набагато ризикованішим, ніж у інших середземноморських країнах. Нагнітання ситуації забезпечили політично заангажовані західноєвропейські та американські 3МI. Зокрема, німецькі телеканали, друковані та 
інтернет-видання значно перебільшували політичні проблеми Туреччини та у негативній конотації висвітлювали діяльність іiі президента, спровокувавши у такий спосіб відповідну реакцію місцевої громадськості. Варто нагадати, що до того часу Туреччина щороку приймала близько 5 млн німецьких туристів.

Зрештою Захід здобув політичну та економічну перемогу у цьому протистоянні: Іспанія, Франція, Італія та Греція збільшили доходи від іноземного туризму; свої фінансові інтереси, як наслідок, задовольнили німецькі кредитори Греції та Іспанії; туристичний сектор Сполучених Штатів отримав додаткові прибутки від зростання попиту на послуги національних круїзних компаній.

Політичне підгрунтя мали і запроваджені у 2017 році заходи американського уряду із «забезпечення суворого дотримання закону про заборону туризму», що за офіційною аргументацією, «спрямовані на обмеження грошового потоку репресивним елементам кубинського режиму».

Взятий у грудні 2014 року курс на нормалізацію двосторонніх відносин відкрив можливості для відвідувань Куби громадянами США. Американці, як і раніше, не могли відвідувати острів Свободи на правах звичайних туристів, однак отримали змогу приїхати на нього, віднісши себе до однієї з 12 дозволених і достатньо умовних категорій: до країни був дозволений в'їзд із культурною, освітньою, релігійною, гуманітарною цілями та з метою відвідування родичів. У серпні 2016 року між США та Кубою було відновлено регулярне авіасполучення, а американські круїзні судна одержали дозвіл на прибуття до кубинських морських портів.

Однак на думку сучасної адміністрації Білого дому, особисті поїздки за індивідуальними запрошеннями «підвищують ризик потенційного зловживання законом». Крім того, Держдепартамент опублікував перелік кубинських готелів, які за його версією, належать силовим структурам Куби. Відпочинок там був заборонений, як i фінансові операції з ними.

В той же час, за прогнозами фахівців, нинішній потік мешканців США, які в обхід блокади прибувають на Кубу через Мексику та Канаду, після скасування ембарго міг би зрости 31 до 5 мільйонів туристів на рік. [3]

3. Фактори непрямого позитивного впливу. Суттєве значення для компаній, які ведуть операції в інших країнах, мають фактори політичної стабільності та інтеграції. Цілком очевидно, що пом'якшення міжнародного політичного клімату i формування добросусідських відносин між державами стимулюють туристичну 
активність населення. Так, відкриття кордонів та перехід до ринкових економічних систем країн Східної Свропи призвели до збільшення продукованих ними міжнародних туристичних потоків. Багато держав регіону, зокрема Угорщина, Чехія, Польща, зайняли провідні позиції і у прийомі іноземних туристів. У свою чергу, наявність єдиної візи, практична відсутність митного контролю та введення єдиної валюти постало важливим чинником підтримки розвитку міжнародного туризму у країнах Свропейського Співтовариства.

Важливе значення для системи міждержавних відносин в галузі туризму, які будуються на принципах мирного співіснування, мали також рішення, прийняті в рамках Хельсінкської Наради з питань безпеки і співробітництва у Свропі 1975-го року.

Інтернаціоналізація туристичного бізнесу та посилення економічних і політичних зв'язків між країнами дають підстави для включення до цієї групи факторів і ряду в цілому нейтральних щодо наслідків впливу адміністративно-правових норм, правил та процедур, що встановлюються окремими державами 3 метою внутрішнього регулювання таких питань, як оподаткування, патенти, трудові відносини, стандарти якості послуг, ціноутворення та надання відомостей державним установам.

4. Фактори непрямого негативного впливу. Об'єктивні події політичного характеру та непрораховані стратегічні рішення урядів через дію опосередкованих механізмів можуть мати незворотні наслідки і для туризму.

Згідно 3 даними нещодавно опублікованого звіту Асоціації британських турагентств (АБТА) про вплив Brexit на туризм, у випадку виходу Великої Британії з СС свобода пересування британських мандрівників по Європі та європейців по Британії стане значно меншою. На думку експертів, невизначеність щодо результату започаткованого політичного процесу дезінтеграції також послаблює фунт стерлінгів відносно інших валют i може призвести до подорожчання для місцевих мешканців виїздів на континент.

I це у той час, коли 76\% закордонних туристичних подорожей та $68 \%$ ділових візитів британців сьогодні припадають саме на $\mathrm{CC}$, а в структурі в”їзого туристичного потоку до Сполученого Королівства громадяни $\mathrm{CC}$ становлять $63 \%$ серед подорожуючих 3 метою відпочинку та 73\% - серед бізнес-туристів. Вони ж забезпечують $44 \%$ доходів країни від туризму. Самі британці залишають на території Свросоюзу 56\% своїх витрат на мандрівки.

Переважно через сумнівні політичні проекти та декларації протягом 2016-2017 спостерігалося тенденційне скорочення кількості 
прибуваючих туристів i до Сполучених Штатів. Адміністрація попереднього президента країни Барака Обами надавала туризму суттєву підтримку: наприклад, у 2010 році був підписаний закон про заохочення подорожей, в результаті якого була створена Brand USA національна маркетингова організація; багато держав приєдналися до програми безвізового в”їзду. Прямим наслідком цих дій стало збільшення в період з 2009 по 2016 роки обсягів міжнародних прибуттів до США на 40\%. Наступний очільник Білого дому після вступу на посаду навпаки видав декілька резонансних указів, що тенденцію докорінно змінили: про заборону в'їзду до країни громадянам деяких мусульманських країн, про будівництво стіни вздовж мексиканського кордону тощо. Національне бюро подорожей $\mathrm{i}$ туризму відзначає, що станом на липень 2017 року спад відбувся по 20 країнах, що є основними ринками туристів для США. [4]

Стримуючий вплив на туристичну активність мають також несприятливі політичні режими. Так, через політику апартеїду, що свого часу проводилася Південно-Африканською Республікою, від багатьох міжнародних туристичних компаній громадськість вимагала припинення будь-яких стосунків 3 цією країною.

Неможливо відокремити від політичного контексту і північнокорейський туризм. Тиск, який чинить уряд цієї країни на процес регулювання розвитку галузі, порядок організації турів, зміст програм туристичного обслуговування та маркетинг не послаблювався і не змінювався десятиріччями. Хоча останніми роками і були вжиті деякі, здебільшого символічні, кроки, що повинні сприяти перетворенню Північної Кореї на більш відкритий та різноманітний туристичний напрям.

Отже, як підсумок можна констатувати, що у теперішній час проведення єдиної міжнародної туристичної політики та забезпечення рівних правових умов провадження туристичної діяльності на світових ринках суттєво ускладнені строкатістю організаційних форм управління туризмом, особливостями історичного розвитку та диференціацією економічних потенціалів окремих країн.

При цьому для України завдання оптимізації політичного впливу на індустрію туризму набувають ще більшої актуальності 3 поглибленням процесів іiі входження у розгалужене соціальноекономічне та культурне середовище Європи і світу. В період сучасних інституційних перетворень політичні чинники повинні відіграти подвійну роль: з одного боку, сформувати регламентні норми і правила функціонування туристичних підприємств, установ і організацій, а 3 
іншого - створити юридичні підстави для регу-лювання туризму на основі підходу до нього як самостійної галузі народного господарства.

\section{Список використаних джерел}

1. Tourism Highlights 2018. - Madrid: World Tourism Organization. $-2018 .-16 \mathrm{p}$.

2. Tourism Highlights 2017. - Madrid: World Tourism Organization. $-2017 .-16 \mathrm{p}$.

3. США - Куба: время для диалога [Електронний ресурс]. Режим доступу: https://ria.ru/analytics/20090408/167504719.html.

4. Baker B. How does politics affect tourism? A look at international tourism trends on the back of a possible 'Trump slump' / B. Baker // Filly Voice. - 2018. - February 07.

Цімболинець Г.I., Ужгородський національний університет

\section{ВПЛИВ СУЧАСНИХ ТА ПРОГНОЗОВАНИХ ТРЕНДІВ ТРУДОВОЇ МІГРАЦІЇ НА ЕКОНОМІЧНІ ПРОЦЕСИ В ЗАКАРПАТСЬКІЙ ОБЛАСТІ}

Протягом всього періоду незалежності України кількість трудових мігрантів зростала майже кожного року, особливо посилилися еміграційні процеси останнім часом, на що мала в основному вплив затяжна економічна та соціальна криза, нестабільна політична ситуація та недовіра до влади, а також несприятливе середовище для ведення бізнесу та інноваційного прогресу.

Україна стала донором робочої сили для багатьох розвинених країн світу і надалі за прогнозними оцінками буде складати досить значну частку економічно активного населення країн $\mathrm{EC} \mathrm{та}$ Північноамериканського континенту.

Найбільшу кількість трудових мігрантів складають жителі Західних регіонів країни, особливо Закарпатської області, адже даний регіон відноситься до територій 3 низьким рівнем розвитку продуктивних сил та індустріалізації, тому мотиви пошуку роботи за кордоном тут досить очевидні, адже більшість місцевих жителів виділяють саме потребу у забезпечені сім'ї як основну причину виїзду за кордон [1, С.144-148]. До ключових особливостей закарпатської трудової міграції відносять також: 
1. Ланцюговий характер, адже вдале працевлаштування одного із членів родини нерідко спричиняє працевлаштування й інших родичів та знайомих. Особливо значущим цей фактор $\epsilon$ в сільській місцевості, де традиційно наявні розгалужені по населеним пунктам сільського типу родинні зв'язки і груповий характер працевлаштування чоловіків, які серед трудових мігрантів кількісно переважають.

2. Виїзд за кордон висококваліфікованих спеціалістів, що спричинено курсом розвинених країн на інноваційний шлях розвитку, що формує попит на високоінтелектуальну працю.

3. Стабільно найбільша кількість трудових мігрантів проживає в гірській та сільській місцевості, а найменше в низинній зоні та містах [2, С.65].

Економіка Закарпатської області вже відчула на собі вплив значної кількості втрати економічно активного населення. Розглядаючи динаміку основних показників ринку праці Закарпаття, можна простежити, що ситуація протягом 2011-2018 pp. погіршувалася, рівень безробіття зростав, чисельність економічно активного та зайнятого населення зменшувалася. Дана ситуація посприяла щорічному збільшенню трудових мігрантів із області, що в подальшому також призвело до негативних наслідків. Основні показники рику праці регіону наведено в рис 1 .

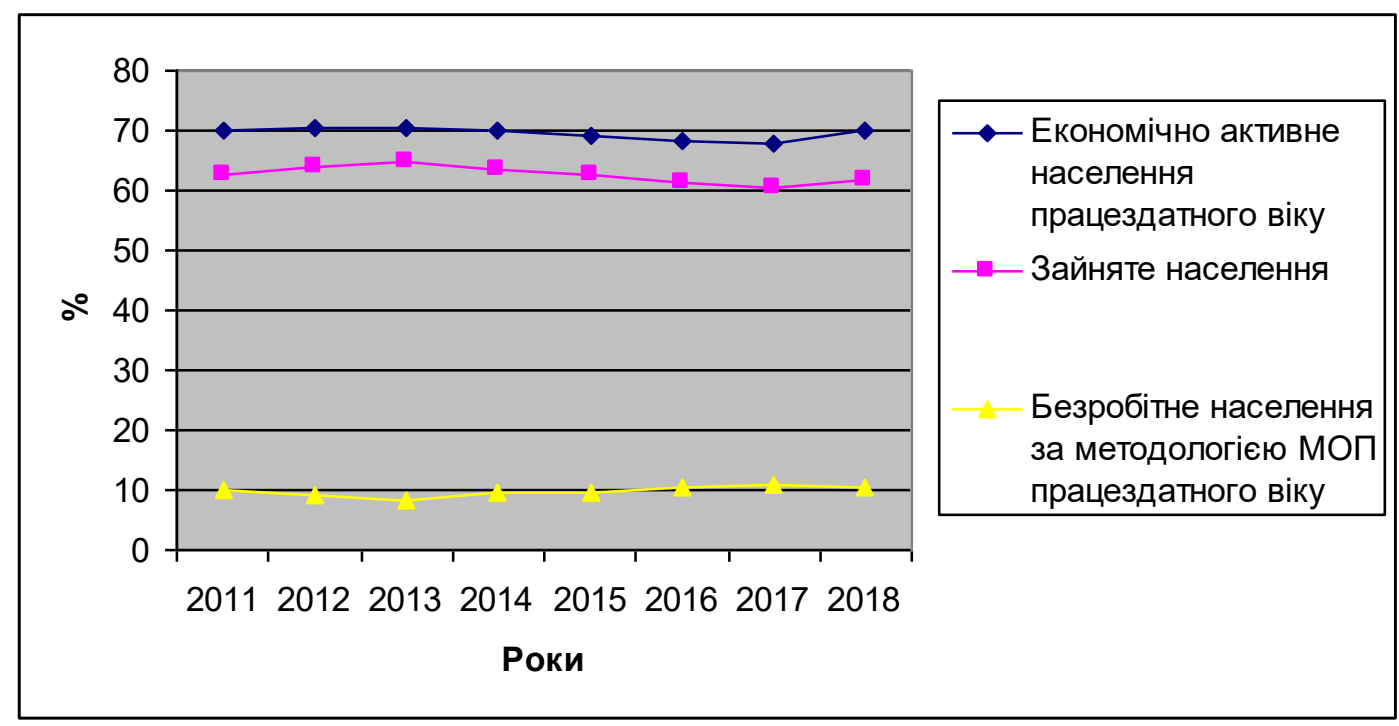

Рис. 1 Показники ринку праці Закарпатської області [3]

Незначне покращення показників спостерігалось в 2018 році, рівень безробіття зменшився на $0,6 \%$ до $10,3 \%$, але якщо порівняти показник безробіття з відповідними показниками сусідніх країн, то побачимо, що в них він різко зменшується: в Угорщині - 4,3\%, Польщі $-4,8 \%$, Словаччині - 7,5\%. Отже, в Закарпатській області ситуація 
несприятлива, оскільки велика частина населення працює за кордоном, деякі експерти називають цифру в 200 тис. трудових мігрантів, на ринку праці спостерігається значний дисбаланс між попитом та пропозицією робочої сили та кадровий голод в деяких галузях. Найбільшим попитом користуються робітничі професії: швачки, електромонтери, працівники сільського господарства, продавці, медсестри, охоронники, перукарі. Велика частка трудових мігрантів саме й виконують зазначену роботу адже заробітна плата за кордоном в декілька разів перевищує середню заробітну плату в регіоні. Так, в 2018 році середньомісячна заробітна плата в Закарпатській області становила 7776 грн., що еквівалентно 275 дол. США, для порівняння в країнах-реципієнтах трудових мігрантів дані показники становлять: Польща - 2307 дол. США, Словаччина - 2144 дол. США, Угорщина дол. США, Чехія - 2260 дол. США, Німеччина - дол. США, Італія 2955 дол. США, Іспанія - 2837 дол. США, Португалія - 1434 дол. США. Отже, різниця значна і досягнути такої оплати праці поки що нереально за сучасних економічних умов.

Можна підсумувати, що трудова еміграція, окрім позитивних аспектів, таких як насичення економіки грошовими переказами, спричинила диспропорції на ринку праці і тим в подальшому несе в собі загрозу кадрового голоду на підприємствах області та браку робітничих професій [4].

Має місце ситуація коли дана проблема є замкнутим колом: низький рівень соціально-економічного розвитку, безробіття та низький рівень заробітної плати по відношенню до споживчих цін спричиняють збільшення трудової еміграції українського населення, вона в свою чергу спричиняє також економічні диспропорції, створюючи дисбаланс на ринку праці та гальмуючи розвиток держави.

За результатами дослідження Міжнародної організації праці, прогнозується потенційне подальше зростання трудової міграції на $12 \%$, стабільно найбільший потенційний потенціал у західних регіонах-Тернопільській, Волинській та Закарпатській областях.

На стан міграційних процесів впливають як зовнішні, так i внутрішні чинники. Аналізуючи внутрішню ситуацію в країні, можна констатувати факт, що на даний момент немає позитивних факторів, що сприяли б зменшенню рівня міграції чи повернення значної кількості мігрантів, оскільки держава не має значного впливу на неї через відсутність чіткої міграційної політики та ігнорування наявних проблем.

Зовнішні причини для еміграції будуть також їй сприяти. Так, зокрема аналізуючи міграційну політику та демографічні процеси в 
розвинених країнах світу, можна стверджувати, що ситуація дійсно буде погіршуватися, саме ці фактори є першою причиною їх активної імміграційної політики. У багатьох країнах іммігранти збільшують чисельність населення: у США - майже на 50\%, у Канаді на 70\%, Швеції - 80, Угорщині - 100\%. Друга причина - емігранти збільшують пропозицію робочої сили. Наприклад, у Канаді 2018 року вже понад 75\% приросту робочої сили відбувається завдяки мігрантам, а 2034p. цей показник становитиме $100 \%$. Така сама ситуація у Швейцарії. Третя причина - іммігранти сприяють зростанню ВВП, прогнозується, що якщо не залучати іммігрантів, то до 2040 р. темпи зростання ВВП упадуть вдвічі. Це відбудеться через те, що зменшення кількості трудових ресурсів призведе до зменшення кількості капітальних та іноземних інвестицій, податків та платежів [5].

Через погіршення демографічної ситуації та прискорення еміграції все більше країн зазначають, що мігранти потрібні зараз. Наприклад, позиція міністерства у справах Канади така: чим скоріше мігрант приїде в країну, то швидше буде відчутний соціальноекономічний ефект від його діяльності. Досвід США також показує, що чим скоріше легалізувати мігранта, тим скоріше і вище буде зростання країни. Оскільки це не тільки робочі руки, а споживачі й платники податків.

Стає очевидним, що активізація політики імміграції в країнах Європи та Північної Америки призводять до трудової еміграції та виникнення дефіциту трудових ресурсів. Із кожним роком у нашій країні зменшується частка економічно активного населення. 2018 році за даними Держстату, з 42 млн. населення майже 28\% (11,7 млн.) пенсіонери, ще 26\% (11 млн.) - економічно неактивні, близько 7-10\% (3-5 млн.) працюють за кордоном. Залишається всього 15 млн. (36\%) економічно активних людей [6]. Однак багато експертів зазначає, що реальна кількість набагато менша, ніж в статзвітності. Тому необхідно негайно вживати заходи по усуненню основних причин еміграції та налагодження зв'язків з мігрантами, забезпечити їм гідні умови праці та соціального захисту для повернення хоч якоїсь частини додому, а також зменшити темпи міграції, що в перспективі можуть привести до поглиблення кризи та руйнівних наслідків для економіки.

\section{Список використаних джерел}

1. Рюль В. Специфіка закарпатської транскордонної трудової міграції та соціальних процесів пов'язаних з нею / В. Рюль // Науковий вісник Ужгородського національного університету. Серія : Педагогіка. Соціальна робота. - 2012. - Вип. 24. - С. 144-148. 
2. Регулювання трудоміграційних процесів в транскордонному регіоні: монографія / за заг. ред. д.е.н., проф. Пітюлича М. I.; [M.I. Пітюлич, В.В. Гоблик, Т.Д. Щербан та ін.] - Мукачево: Вид-во МДУ, 2015. $-148 \mathrm{c}$.

3. Основні показники ринку праці у 2000-2018pp. [Електронний pecypc] // Офіційний сайт Головного управління статистики в Закарпатській області. - 2019. - Режим доступу до ресурсу: http://www.uz.ukrstat.gov.ua/statinfo/pracja/2019/osn_pokaz_20002018.pdf

4. Фущич Ю. На ринку праці Закарпатті величезний дисбаланс [Електронний ресурс] / Юрій Фущич // перший.com.ua. - 2018. - Режим доступу до ресурсу: https://pershij.com.ua/na-rynku-pratsi-zakarpattivelycheznyi-dysbalans/..

5. Гайдуцький А. Боротьба за мігрантів. Україні приготуватися [Електронний ресурс] / А. Гайдуцький // Зеркало тижня. - 2018. Режим доступу до ресурсу: https:/dt.ua/internal/borotba-za-migrantivukrayini-prigotuvatisya

289703_html?fbclid=IwAR1Um_qEWKWz7Sjs7YvLJbgzCh8FJ4XZls 6o63SvFow3YX2KszwyVkL7cM.

6. Щур М. Що робити Україні в епоху високого попиту на українців? [Електронний ресурс] / М. Щур // Радіо Свобода. - 2017. Режим доступу до ресурсу: https://www.radiosvoboda.org/a/28330699.html?fbclid=IwAR1IIZQtB0wVCqH38axHPFNGPdO_hveL-Yh3VfGKeJr5jT7VZfpEIeTuOo.

Черленяк I.I., д. н.держ.упр, професор Ужгородський національний університет

\section{ЕКОНОМІЧНА ВЛАДА ТА ЕВОЛЮЦЙНА ЕФЕКТИВНІСТЬ ПОЛІТИЧНИХ ЦИКЛІВ В УКРАЇНІ}

Економічний розвиток України в умовах транзиту від однієї економічної системи до іншої за останні три десятиліття демонструє «інверсно-трансформаційну» суперечність напрямку руху. $\mathrm{He}$ зважаючи на «лавину» заяв, дій та трактувань логіки інтересів соціуму та владних кіл, що обгрунтовують нову економічну політику на початку кожного політичного циклу, усе ж відбувається неминуче 
повернення до перед трансформаційної диспозиції. Говорячи про владні кола, ми маємо на увазі не тільки обрану в процесі виборів державну політичну владу, але і владу економічну. Вважаємо, що саме економічна влада в пострадянському суспільстві $\epsilon$ найбільш важливим актором трансформаційного процесу.

Свідчення цьому те, що на початку кожного політичного циклу в публічному просторі «заявляються» та обговорюються економічні та соціально-економічні реформи, розробляються плани реформ, проголошуються різні програми реформування галузей. В січні 2004 року :Розділення влади та бізнесу». В квітні 2014 року говориться «Жити по новому». В квітні 2019 знову «Весна прийде, саджати будемо». Говориться знову про модернізацію принципів здійснення адміністрування, розробку методів проведення «нової» економічної політики. І усі ці наміри нібито спрямовані наступально вперед, подалі від невдалого економічного «минулого». Але економічне минуле чомусь повертається з кожним новим політичним циклом. Чому? Кому вигідно?

Стосовно особистих або афілійованих інтересів тих, хто отримав «офіційне» право говорити про реформи, або тих владоможців, хто має приватні телеканали, то «трансформаційні» економічні рішення приймалися і приймається наступально в часі. Але ця наступальність насамперед виражається в створенні тактичних монопольних переваг для окремих компаній та сегментів бізнесу. Або у формуванні тактичних особливих преференцій в оподаткуванні чи приватизації. Вона може мати вигляд: «недбалості» рішень антимонопольного комітету стосовно «преміювання преференціями» явних монополістів;, державних гарантій під приватні контракти; вибіркових відшкодувань ПДВ; особливих «зелених» цін на енергоносії для виділених компаній; вибірковий дозвіл на розробку родовищ газу, нафти. титану тощо для «своїх» людей та фірм. Варіантів такої усе більш «нової» «економічної політики» достатньо багато. Ці прояви «демократії для своїх» в економічній транзитології ідентифікують як «роздаткова економіка»[1].

Тактично, з точки отримання прибутку найбільш багатими в Україні безпосередньо носіями економічної влади використання інструментів роздаткової економіки виправдані. Але стратегічно вони згубні не тільки для широкого загалу економічних агентів України, але і для тих самих носіїв економічної влади, що акторко сформували роздаткову економіку. Більше того, усі вищеназвані тактичні прийоми носіїв економічної влади безперервно руйнують фундаментальний модернізаційний сенс трансформаційних перетворень в Україні: 
створення зовнішньо-конкурентної економіки, створення внутрішнього конкурентного середовища для прискорення мотиваторів розвитку суб’єктів економічної діяльності.

Проти такого ходу корисливих та шкідливих для суспільствадержави-країни трансформаційних перетворень активні соціальноекономічні актори України висловили публічний протест у формі трьох вуличних революцій: «Революції на граніті», «Помаранчевої революції», «Революції Гідності». Ці революції мабуть сприяли б якості формування політичної та економічної влади в країні. Але завжди відбувалося ще більш успішне переформатування тих сил економічної влади, які не зацікавлені в зміні стану перманентної трансформації, а зацікавлені в збереженні системи «влада-власністьмонополія».

До того ж трутилися в хід історичних еволюційнх подій і зовнішні негативні чинники та обставини. Перша негативна обставина: після відходу з геополітичної арени першого російського правителя-демократа Б.Сльцина в Кремлі цілком сформувався азійсько-деспотичний комплекс «влада-власність», основні ознаки якого описані в роботі [2]. Друга негативна обставина: кремлівському комплексу «влада-власність» шляхом торгових воєн та маніпулятивно-провокативних операцій цивілізаційного та геополітичного вдалося розв'язати оздоблену благородними гаслами про допомогу «братньому» українському народу спочатку скриту, а потім i відкриту гібридну війну проти економіки, соціальної стабільності та політичної системи України. Внаслідок, усі три революції замість підйому принесли тяжкі економічні та ресурсні втрати для України. Ці втрати ще більш посилили тягар трансформаційної кризи, який лежить на плечах середнього та бідного класу України. У цьому зв’ язку сьогодні критично важливо осмислити глибинні причини, як внутрішні так i зовнішні наших трансформаційних невдач.

Вважаємо, що доцільно виходити 3 тези синергійності та компланарності політичної, економічної та соціальної самоорганізації. Тобто, вважаємо, що в країнах пострадянського транзиту, що не пройшли історичний шлях органічної модернізації в 17-19 столітті, економічна трансформація повинна проходити свої сучасні етапи взаємно рефлексивно iз соціальною трансформацією та трансформацією організаційної культури цивілізаційного середовища країни. Це дещо суперечить позиції С. Хантінгтона, який заперечував вплив політичного розвитку на економічну модернізацією та на накопичення позитивних зрушень суспільного життя.[3] Проте вона 
співзвучна конструктивістській позиції Ернандо де Сото: політична та економічна стабільність повинна базуватися на таких принципах демократії та ринкової економіки, що здатні забезпечити конкуренцію та виключення монополії та диктату.[4]

Для подолання трансформаційної кризи українській управлінській та економічній науці необхідно більш глибоко та конструкційно опрацювати проблеми економічної влади та політичного ринку. Розробити на рівні моделювання форсайту та інших аналітичних моделей, що ж усе таки мішає на фундаментальному рівні завершенню трансформаційної кризи в Україні? Що перешкоджає руху вперед економіки України окрім гібридної війни кремлівської влади?

Україна формально ніби і рухається в колії модернізації. Певні досягнення на шляху суспільного транзиту на шляху модернізації очевидні. У країні формально. при підтримки міжнародних організацій та демократичних країн, розвивається політична «виборча демократія». Відбуваються конкурентні вибори. Нібито поступово формуються підстави трансформації економічної системи від гіршої якості до дещо кращої якості. Проте, боротьба з корупцією навіть при підтримці громадськості, урядів, спецслужб, диппредставництв провідних демократичних країн дуже туго просувається. А це є одним 3 індикаторів відсутності реальної економічної трансформації.

Другим індикатором якості трансформації країнового господарства $є$ продуктивність праці та продуктивність галузевих комплексів. За цими ознаками в Україні починаючи з 1990 року перманентна трансформаційна криза економіки в цілому та галузей промисловості, зокрема[5].

Вважаємо, що при оцінюванні реального стану та напрямку трансформаційного процесу i влада, i експерти-аналітики, i громадянське суспільство повинні опиратися в своїх оцінках трансформації на певний критерій еволюційної результативності та еволюційної ефективності

Еволюційну ефективність можна оцінювати 3 кількох сторін 1) на основі концепції бенчмаркінгу, порівнюючи профіль продуктивності та конкурентоспроможності країни з глобальними та регіональними лідерами; 2) на основі показників та індексів розвитку відносно базових станів системи що трансформується та еволюціонує.

При затяжній трансформаційній кризі еволюційну результативність потрібно оцінювати насамперед на основі певної системи показників: як далеко система еволюціонувала від початку транзиту в вимірах економічної, галузевих, соціальної, політичної 
структури; як модернізувалися функціональної відповідності згаданих сфер-структур конкурентним викликам; як модернізувалися (змінилися) економічні інститути. Ці завдання формально ставилися, проте на кінець кожного політичного циклу (Л.М.Кравчука, Л.Д.Кучми, В.А.Ющенка, В.Ф.Януковича, П.О.Порошенка) основним завданням, як визначають самі учасники чергових президентських перегонів знову i знову залишається «зміна системи діючих економічних інститутів».

Президентська виборча кампанія представника молодої генерації бізнесу В.Зеленського в квітні 2019 року Президентом України, немов би і не проходила під цими гаслами. Проте віртуальна реальність, створена командою В.Зеленського як довготривалий інформаційнопропагандистський грунт виборчої компанії новообраного Президента України був сформований екстра привабливим для широкої публіки саме на основі ідеологеми: зміна системи несправедливих та злочинних економічних інститутів.

Можливо, творці цієї ідеологічної панорами не хотіли так далеко заходити в своїх трансформаційних цілях та обіцянках. Проте рекордні результати підтримки виборців продемонстрували, що основні соціальні групи в усіх регіонах саме радикальних змін економічних інститутів (правил та норм поведінки акторів бізнесу та функціонерів влади) очікують. Носії економічної влади в таких умовах неминуче будуть думати над дилемою: рухатися на поклон до кремлівського комплексу «влада-власність» чи сприяти прогресу економічної системи України в умовах реалій нового політичного президентського циклу. Але це сприяння неможливо без зміни змісту та якості самої економічної влади першої п’ятірки, десятки, двадцятки та зрештою сотні найбагатших осіб України. Тому насамперед необхідно визначити які фундаментальні одиниці та процеси стануть основою конструювання еволюційно ефективної трансформації інституту економічної влади.

В якості перших практичних кроків впорядкування інституту економічної влади можна розглядати такі кроки:

1) прийняти закон про легалізацію лобізму інтересів та фінансування проектів акторів економічної влади;

2) унормувати лобізм в інформаційній сфері та впорядкувати приховану пропагандистську діяльність приватних телеканалів та інтернет-медіа на користь власників;

3) легалізувати та впорядкувати процес бенефіціарного представництва інтересів економічних влад в парламенті та політичних партіях. 


\section{Список використаних джерел}

1. Бессонова О. Э. Раздаточная экономика как российская традиция //Общественные науки и современность. - 1994. - №. 3. - С. $37-48$.

2. Wittfogel K.A. Oriental despotism. A Comparative Study of Total Power. London:New Haven, 1957.

3. Huntington S. The change to change. Ed. by A. Contory and A. Iegler // Comparative Politics in the Past-Behavioral Era. Boulder; Colorado: Lynne Rinner, 1988. Стор 4.

4. Де Сото Э. Загадка капитала. Почему капитализм торжествует на Западе и терпит поражение во всем остальном мир. Пер. с англ. М.: Олимп-Бизнес, 2001. 256 с.

5. Кораблін С. О. Україна: економічна нестійкість та вади сировинної спеціалізації (за матеріалами наукової доповіді на засіданні Президії НАН України 13 вересня 2017 р.) //Вісник НАН України. 2017.

Шкуропадська Д.Б., Київський національний торговельно-економічний університет

\section{ФАКТОРИ ЗАБЕЗПЕЧЕННЯ СТІЙКОСТІ ЕКОНОМІКИ}

Проблематика підвищення рівня стійкості національної економіки набуває особливого наукового та прикладного значення в умовах глобальної нестабільності та активізації зовнішніх шокових впливів. Стійкість економіки передбачає здатність економічної системи зберігати та нарощувати життєво важливі параметри і функції на всіх етапах циклічного розвитку в умовах зовнішніх і внутрішніх впливів на неї [1, с. 44 ].

На здатність економіки протидіяти та швидко відновлюватися після дії шокових впливів впливає ряд факторів. На рисунку 1 наведена система факторів впливу на рівень стійкості національної економіки. 


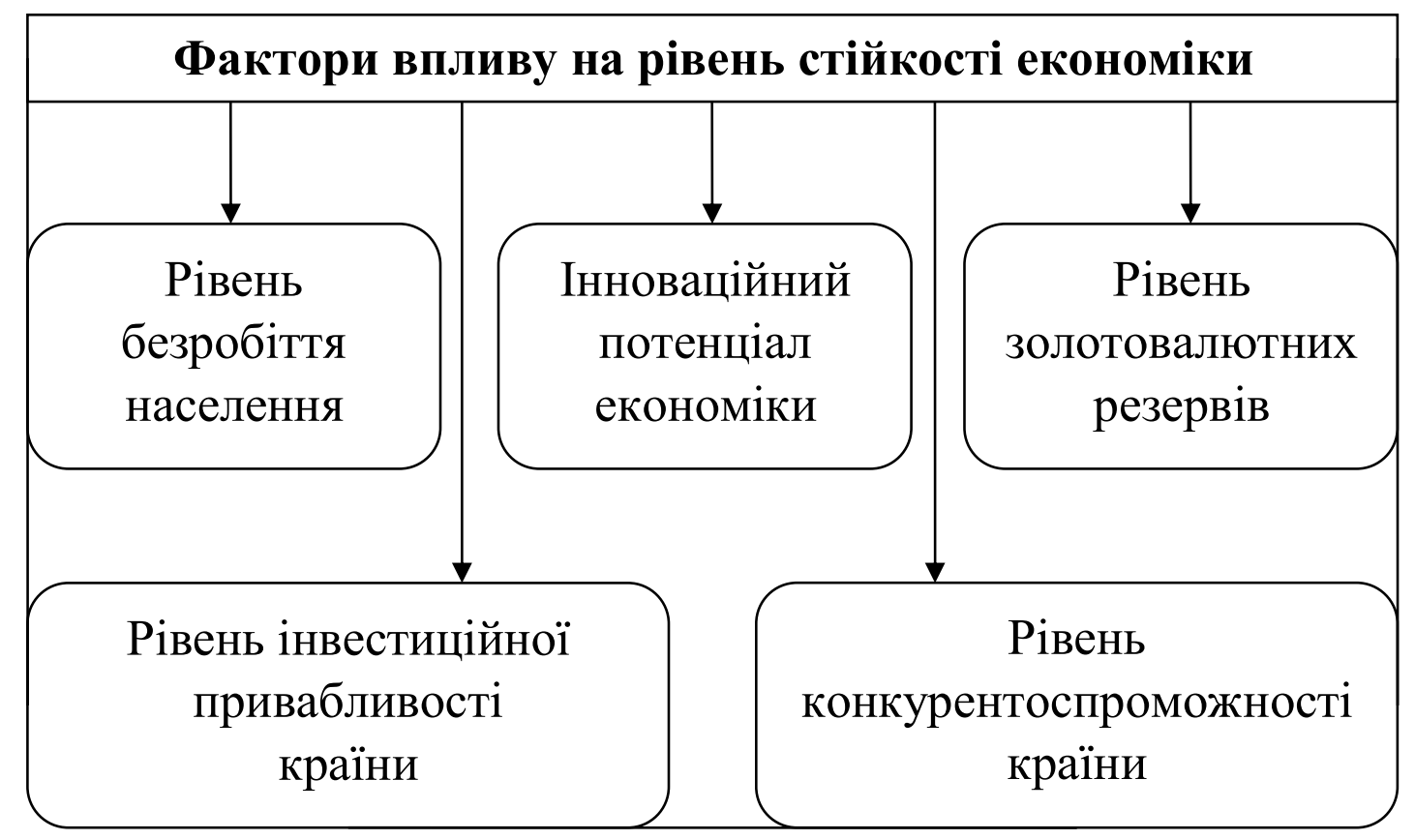

\section{Рис. 1. Система факторів впливу на рівень стійкості національної економіки.}

Джерело: розроблено автором

Безробіття як соціально-економічне явище $є$ результатом перевищення пропозиції робочої сили над попитом на неї. Одним із основних показників, що характеризує безробіття і використовується при аналізі тенденцій розвитку економіки, є рівень безробіття. Рівень безробіття показує відношення безробітного населення до загальної чисельності працездатного. Створюючи резерв безробітних, економіка обмежує потенціал свого стабільного розвитку та забезпечення стійкості.

Рівень безробіття в Україні у 2014-2018 рр. коливався від 9,1\% до $9,9 \%$. Оскільки пороговим значенням рівня безробіття є $10 \%$ (відповідно до Методики розрахунку рівня економічної безпеки України), то значення цього показника протягом досліджуваного періоду знаходилось у безпечній зоні.

Однією з ключових складових економічного потенціалу країни $€$ інноваційний потенціал. Інноваційний потенціал, як фактор забезпечення стійкості економіки, характеризує рівень розвитку науково-технічних, технологічних, інфраструктурних, фінансових, правових, соціокультурних та інших можливостей для забезпечення реалізації інновацій. Інновації, як новітня комбінація виробничих та інтелектуальних ресурсів, стимулюють розвиток інноваційних методів виробництва товарів і послуг, та пошук нових джерел сировини, технологій. У свою чергу, виробництво інноваційних продуктів та 
технологій забезпечує формування нових ринків збуту, що в результаті стимулює економічне зростання.

Рейтинг Глобального індексу інновацій щорічно складають Корнельський університет спільно зі школою бізнесу INSEAD та Всесвітньою організацією інтелектуальної власності (BOIB). Рейтинг формується за результатами аналізу рівня впровадження інновацій у сфері інституцій, освіти, інфраструктури та бізнесу. Глобальний індекс інновацій України у 2014-2018 рр. коливався від 35,72 до 48,09 балів із 100 можливих.

Одним $з$ надійних факторів забезпечення стійкості економіки та платоспроможності держави $€$ золотовалютні резерви. Під золотовалютними резервами розуміють офіційні централізовані запаси резервних ліквідних активів, які перебувають у розпорядженні центрального банку і використовуються для міжнародних розрахунків, погашення зовнішніх боргів, регулювання ринкових курсів національної валюти та вирішення інших національних завдань. Рівень золотовалютних резервів України у 2014-2018 pp. зріс на 13287,7 млн. дол. США або на 176,37\%. Станом на 28 лютого 2019 р. золотовалютні резерви України становили 20220,5 млн. доларів США. За обсягом золотовалютних резервів серед 164 країн світу Україна у 2017 р. зайняла 56 місце [2].

В умовах тривалої нестабільності економічного середовища, надходження іноземного капіталу в країну $є$ ключовим фактором економічного зростання та розвитку. Інвестиції забезпечують сприятливий фінансовий клімат країни, є додатковим джерелом капіталовкладень в національне виробництво товарів і послуг.

Під інвестиційною привабливістю країни розуміють сукупність політичних, соціальних, інституційних, екологічних, макро- та мікроекономічних умов функціонування економіки, що забезпечують стабільність інвестиційної діяльності національних та іноземних інвесторів. Інвестиційна привабливість України визначається за індексом інвестиційної привабливості, який розраховується міжнародною консалтинговою організацією BDO. У 2014-2018 pp. індекс інвестиційної привабливості України коливався від 2,51 до 3,1 балів із 5 можливих. На протязі 2017-2018 pр. індекс тримався на рівні вище 3 балів, що свідчить про його вихід з негативної площини.

В умовах глобальної нестабільності, забезпечення конкурентоспроможності країни $\epsilon$ ключовим фактором, який характеризує позиції розвитку української економіки на світовому ринку. Конкурентоспроможність країни характеризується такими умовами: 
- здатність виробляти більший обсяг матеріальних цінностей, ніж інші країни-конкуренти, на світових ринках;

- здатність виробляти товари та послуги, що відповідають вимогам світових ринків;

- створювати умови для нарощування державних ресурсів зі швидкістю, що дозволяє забезпечити стійкі темпи зростання ВВП і якість життя населення на рівні світових значень.

Таким чином, під конкурентоспроможністю країни варто розуміти здатність економіки виробляти товари та послуги, які відповідають попиту на світових ринках, що забезпечує зростання рівня ВВП та підвищення якості життя населення. Для визначення рівня конкурентоспроможності країни, використовують індекс глобальної конкурентоспроможності, який розраховується за методикою Світового економічного форуму. У 2014-2018 pp. індекс глобальної конкурентоспроможності України коливався від 4 до 4,11 балів із 10 можливих, що свідчить про низьке його значення.

Отже, розглянуті фактори забезпечення стійкості економіки безпосередньо впливають на темпи економічного зростання. В умовах шокових впливів економічне зростання забезпечить збереження рівня стійкості економіки у межах допустимих (порогових) значень.

\section{Список використаних джерел}

1. Бойко А.В. Стійкість національної економіки: теорія, методологія, практика: монографія. Київ: Ін-т екон. та прогнозув. НАН України, 2014. - 288 с.

2. Золотовалютні резерви країн світу. Світовий банк. NONEWS. URL: https://nonews.co/directory/lists/countries/gold

Шкутько О.Н., к.э.н., доцент, Белорусский государственный экономический университет

\section{ОБРАБАТЫВАЮЩАЯ ПРОМЫШЛЕННОСТЬ РЕСПУБЛИКИ БЕЛАРУСЬ: НАПРАВЛЕНИЯ РАЗВИТИЯ И ТОЧКИ РОСТА}

Обрабатывающая промышленность играет ключевую роль в промышленном развитии стран и мировой экономики в целом. Она обеспечивает возможности воспроизводственного роста, гармоничное сочетание различных видов экономической деятельности (секторов), а 
также стимулирует развитие технологий и инноваций, технологическую модернизацию страны и устойчивый рост производительности труда.

Кроме того обрабатывающая промышленность оказывает воздействие на структуру занятости, уровень оплаты труда и устойчивость на разных этапах развития экономики страны. С одной стороны, меняется структура национальной экономики, обычно обеспечивается переход от трудоемких производств к более капиталои технологически емким. С другой стороны, использование капитала, технологий и инноваций приводит к изменению структуры производимых товаров, производственных процессов и экспортных возможностей в каждой из подотраслей обрабатывающей промышленности.

Более того, несмотря на более высокие, чем ожидалось, темпы восстановления мировой экономики после глобального финансового кризиса страны продолжают сталкиваться с усилением экономической неопределенности, ростом неравенства, низкими темпами экономического роста, увеличением торговых конфликтов, постоянным усложнением нетарифных (относящихся к качеству, безопасности и экологическим стандартам) и ростом тарифных барьеров, в то время как высокие темпы технического прогресса порождают как новые проблемы, так и новые возможности.

Несмотря на бурный рост сферы услуг, эффективная структура отраслей обрабатывающей промышленности является объектом активной государственной политики, фактором международной конкурентоспособности и роста производительности, инноваций и технологий и внешней торговли.

Следует выделить, что современное промышленное развитие Республики Беларусь формируется под воздействием таких внешних факторов как: - последствия сырьевого, финансового, энергетического кризисов; - эффективное использование в промышленной политике развитых стран и стран НИС технологических укладов и разрывов; - в промышленной политике стран переход от стратегии сокращения издержек к формированию планов развития; - изменение стоимости производства в обрабатывающей промышленности, через использование цепочек добавленной стоимости; - развитие системы обмена результатами интеллектуальной деятельности: торговля лицензиями на использование технологий и компьютерными информационными сетями;- международный обмен специалистами; акселерация методов продвижения товаров и услуг, включая транспортировку, хранение, страхование, маркетинг, рекламу и 
организацию товарных потоко; - нестабильность мировых цен на ресурсы; - изменение структуры нефтяного рынка; - неоднозначность денежно-кредитной политики стран-эмитентов резервных валют; неопределенность в основной стратегии интеграционной деятельности в рамках ЕАЭС; - девальвационные влияния национальных валют стран- участниц ЕАЭС [2, с.87].

При этом, достаточно очевидно, что промышленность является ключевым сектором на этапе индустриального развития. Без собственной инновационной и эффективной обрабатывающей промышленности экономика Беларуси вряд ли сможет решить задачи модернизации других секторов, диверсифицировать экономику, уйти от нефтегазовой зависимости.

Важность обрабатывающей промышленности для национальной экономики подтверждается:

- существующей долей в ВВП (22, 2\% в 2017г.);

- высокой долей занятости (19,9\% от общей занятости);

- высокой долей в экспорте (94\% от экспорта промышленности);

- высоким удельным весом производства калийных удобрений в мире (45\% от мирового производства);

- высоким удельным весом производства азотных удобрений в мире (11\% от мирового производства);

- долей мирового рынка металлокорда (14\% от мирового производства);

- долей мирового рынка большегрузных автомобилей (5\% от мирового производства).

Обрабатывающая промышленность Беларуси разнообразна по своему составу. Ведущими отраслями обрабатывающей промышленности, на долю которой приходиться 88\% (2017 г.) общего объема производства продукции промышленности являются: пищевая промышленность $\quad(27,9 \% \quad$ в $\quad$ объеме обрабатывающей промышленности), производство нефтепродуктов $(15,9 \%)$, машиностроение $(14,7 \%)$, химическое производство (9,9\%) [1].

Вместе с тем, сложившаяся отраслевая структура национальной обрабатывающей промышленности оказывает давление на возможности структурной диверсификации в силу их технологического уровня и конкурентного развития, при одновременной нарастающей зависимости от импорта таких ресурсов, как капитал и промежуточные товары.

Доля Беларуси в мировой добавленной стоимости обрабатывающей промышленности составляет 0,14 \% (2015 г.). Что может быть связано с существующим технологическим уровнем 
развития, степенью аутсорсинга отдельных элементов цепочек добавленной стоимости обрабатывающей промышленности в отрасли сферы услуг, отсутствием политики стимулирования формирования как глобальных, так и региональных (в рамках ЕАЭС) цепочек добавленной стоимости.

Такие отрасли как пищевая, машиностроительная, нефтепереработка и химическая являются стратегически важными ввиду высокой добавленной стоимости продукции, а также высокого экспортного потенциала, поэтому целесообразно провести анализ выделенных отраслей с целью выявления потенциальных точек роста внутри отрасли. Нужно учитывать также наличие ресурсного потенциала и имеющийся научно-технический и кадровый потенциал в данных сферах.

Поиск возможностей роста и активизация также необходима с целью продвижения на глобальных рынках, повышения конкурентоспособности продукции, что подразумевает дальнейшее привлечение иностранных инвестиций и высококвалифицированных кадров и как следствие повышение научно-технического потенциала отраслей. Более того, развитие этих направлений может иметь не только экономический, но и социальный эффект.

Следует выделить следующие направления развития:

- реконструкция, модернизация и интернационализация традиционных ведущих отраслей;

- переход в межотраслевой специализации (смена поколений продукции, в результате развития наукоемких отраслей);

- рост услуг, сопровождающих обрабатывающую промышленность;

- локализация производств.

Сокращению наметившихся в последнее время разрывов в индустриальном развитии Беларуси с рядом ведущих стран региона будут способствовать улучшение качества и структуры экспорта промышленной продукции, а также рост ВДС обрабатывающих производств на душу населения, сохранение разумного баланса в промышленно-экспортном потенциале страны. Важным остается использование сложившихся в последние годы высоких темпов наращивания экспортного потенциала в промышленных видах деятельности в направлении расширения национального богатства.

Как уже отмечалось, обрабатывающая промышленность выступает мощным драйвером исследований и разработок. Многие инновации и технологии этого сектора могут с успехом использоваться в различных отраслях экономики, усиливая эффект мультипликации. 
При этом рост может осуществляться на основе различных факторов (конкурентных преимуществ), например: - за счет совершенствования технологий (роста технологического потенциала); - путем повышения ресурсного потенциала и более эффективного использования ресурсов; - на основе повышения эффективности управления и информационного обеспечения; - за счет повышения качества человеческого потенциала, транспортной инфраструктуры и т.п. Таким образом, точкой роста при данном подходе также является наличие в отраслях определенного потенциала и его активация в результате инновационной деятельности [3, с. 240].

Таким образом, точки роста характеризуются своей отраслевой принадлежностью к определенному виду деятельности (которая определяет сферу их возникновения); аспектом потенциала, на основе которого, осуществляется рост; и способом, которым осуществляется развитие точки роста.

С другой стороны, с учетом изучения промышленной основы развития постиндустриальной экономики в передовых странах мира после недавнего глобального финансового кризиса, надо отметить, что все больший интерес представляют отрасли обрабатывающей промышленности в контексте формирования длинных воспроизводственных цепочек при относительно низкой удельной валовой добавленной стоимости в общем объеме товарного производства.

Учитывая приоритет инновационного пути развития, это направление может стать перспективным только при условии модернизации отдельных предприятий и выпуска новых, конкурентоспособных на мировом рынке видов продукции.

В частности, для страны целесообразно последовательно оценивать следующие аспекты: конвергенцию циклов роста в динамике макроэкономического развития; структуру совокупной добавленной стоимости; уровень индустриализации и секторальные распределения; структурные сдвиги в общем экономическом и промышленном развитии; способность производить и экспортировать основные виды промышленной продукции; производственный и экспортный потенциал; значимость и влияние отрасли обрабатывающей промышленности на общую валовую добавленную стоимость (ВДС) в регионе СНГ; взаимосвязь роста и влияния ВДС и экспорта в обрабатывающей промышленности; обобщающие индикаторы эффективности обрабатывающей промышленности в региональной интеграции. 


\section{Список используемых источников}

1. Национальный статистический комитет: официальный сайт. Режим доступа: http://www.belstat.gov.by - Дата доступа: 18.03.2019.

2.Праневич А.А. Факторы конкурентоспособности малых стран и особенности их формирования в Республике Беларусь // Экономический вестник университета. Сборник научных трудов ученых и аспирантов. 2015. № 26-1. С. 86-92.

3. Шкутько О.Н. Особенности организации промышленной политики развивающихся стран в условиях интернационализации // Управление в условиях глобальных мировых трансформаций: экономика, политика, право. Сборник научных трудов. 2018. С. 238241.

Шубін В.Д., ДВНЗ «Київський національний економічний університет імені Вадима Гетьмана»

\section{ДО ПИТАННЯ ФУНКЦИЙ ДЕРЖАВИ ТА ЇХ ФІНАНСОВОГО ЗАБЕЗПЕЧЕННЯ}

Сучасна економічна наука сконцентрована на вирішенні складних проблем, що на сьогодні стоять перед людством. Саме тому в останні десятиліття актуалізувалися дослідження, спрямовані на детермінацію місця та ролі держави в економічних відносинах. Це стало результатом пошуку адекватних відповідей на неоднозначні та суперечливі процеси, що відбуваються у світовій економіці. Без перебільшення можна стверджувати, що усі глобальні проблеми людства - від політичних, екологічних до суто економічних - багато в чому залежать від здатності вирішити проблеми, пов'язані з державним втручанням в економічні процеси. Більше того, навіть зараз в наукових колах можна зустріти цілком аргументовані позиції, прихильники яких акцентують на мінімальному рівні державного регулювання економіки. Зрозуміло, що зазначена проблематика напряму пов'язана і $з$ дослідженням тих функцій, що притаманні державі.

Становлення сучасної парадигми функцій держави доволі часто пов'язують 3 вченням Т. Гоббса [1], який вважав що першою i неодмінною функцією держави $\epsilon$ захист громадян від загроз зовнішнього характеру. В цьому контексті в першу чергу мова йде про 
зовнішні військові загрози, проте ця функція реалізується і через нарощування внутрішнього безпекового потенціалу.

Не можна оминути увагою і роботи Дж. Локка, який у розумінні функцій держави виходив 3 необхідності пошуку тих напрямів і форм діяльності, що не притаманні природному станові [2]. Про які напрями діяльності держави йде мова у цьому випадку? По-перше, прийняття законів та функціонування суб'єктів, які забезпечують їх виконання. По-друге, розв'язання суперечок між різними членами суспільства, насамперед, за рахунок діяльності судової гілки влади. По-третє, гарантія реалізації суддівських рішень, в тому числі - за рахунок примусу.

Сучасні вчені, аналізуючи функції держави, насамперед акцентують увагу на іiі суспільному призначенні. Зокрема, П. Рабінович вважає, що «...функції держави - це основні напрями діяльності держави, які розкривають іiі соціальну сутність і призначення в суспільстві» [3]. В свою чергу, О. Варич вказує, що функції держави «...це структурно і змістовно відокремлені напрями діяльності держави, що зумовлені системою об'єктивних факторів, $\epsilon$ засобами реалізації завдань, відображають закономірності організації держави як складної соціальної системи, зумовлюють процес становлення, історичної зміни держав, відображають їх сутність та можливості як суб'єкта міжнародних відносин» [4].

Аналіз сучасної фахової літератури свідчить, що на сьогодні найбільш поширеним $є$ підхід згідно 3 яким усі функції держави поділяються на основні та другорядні (неосновні). До другої групи відносять виконання державою конкретних завдань, що лежать у другорядних сферах суспільного життя [5]. Як правило, до основних функцій відносять ті, що стосуються наступних сфер - політичної, економічної, соціальної, культурної. Доволі часто в якості окремої сфери реалізації функцій держави відносять міжнародну, хоча в цілому ряді робіт ії відносять до політичної діяльності сучасної держави.

В прагматичній площині проблематика реалізації функцій сучасної держави напряму пов'язана 3 питання їх фінансового забезпечення. Саме в цьому контексті відбувається симбіоз наукових підходів до детермінації функцій держави та іiі економічної i фінансової політики. Очевидним є той факт, що без відповідного фінансового забезпечення не варто розраховувати на повноцінне виконання державою своїх функцій. Проте, підкреслимо окремо, наявність відповідного фінансового забезпечення ще не є гарантією ефективного виконання функцій держави, адже тут виникає питання і про структуру фінансування і про ефективність використання ресурсів. 
Аналізуючи досвід України можна переконатися в правильності цього положення.

В прив'язці до функцій держави використовують різні дефініції «фінансова політика», «фінансування», «фінансовий механізм», «бюджетне фінансування» і т.д. Окремі науковці розглядають вплив держави на суспільний розвиток за допомогою фінансів через призму фінансового механізму, розглядаючи його як «сукупність фінансових методів i форм, інструментів та важелів впливу на соціальноекономічний розвиток суспільства» [6].

У тій чи іншій мірі ресурсна компонента функцій держави реалізується за допомогою усіх складових фінансової політики. Проте у найбільш явній формі фінансове забезпечення виконання функцій держави реалізується через бюджетне фінансування. Саме тому бюджетна проблематика знаходиться у центрі уваги сучасної науки як у кількісному, так і якісному вимірах. Формуючи доходну частину, насамперед за рахунок податкових надходжень, держава активно втручається в економічні процеси на макро- та мікрорівнях. Аналогічно слід розглядати і виконання видаткової частини бюджету. Сучасна вітчизняна наука значну увагу приділяє питанням бюджетного фінансування та його змістовним характеристикам. Зокрема, окремі вчені зазначають, що бюджетне фінансування це: «Форма централізованого виділення 3 державного бюджету фінансових ресурсів у вигляді безповоротного, безоплатного надання коштів, інвестицій на розвиток економіки, соціально - культурні заходи, оборону та інші громадські потреби» [7].

Проблема бюджету - одна із найбільш гострих для України на сучасному етапі. Насамперед, тут має йти мова не скільки про кількісні параметри (хоча і тут існують складні проблеми), стільки про низьку ефективність використання фінансових ресурсів у розпорядженні держави. Слід об' єктивно визнати, що на сьогодні жоден з напрямків не фінансується в достатній мірі результативно, що відбивається на суспільних настроях.

\section{Список використаних джерел}

1. Гоббс Т. Левиафан, или Материя, форма и власть государства церковного и гражданского. М.: Мысль, 1991. 545 с.

2. Локк Д. Два трактата о правлении / Сочинения. М.: Мысль, 1988. С. 135-406.

3. Рабінович П.М. Основи загальної теорії права та держави : [навч. посібник]. Вид 6-е. Харків : Консум, 2002. 160 с. 
4. Варич О. Г. Економічні функції сучасної держави: природа, зміст, тенденції розвитку в Україні: дис... канд. юрид. наук: 12.00.01. К.: Інститут держави і права ім. В. М. Корецького НАН України, 2006. 209 c.

5. Скакун О. Ф. Теорія держави і права : підручник. К.: Правова єдність, 2010. 520 с.

6. Опарін В. М. Фінанси (загальна теорія): Навч. посібник. К.: КНЕУ, 2002. 240 c.

7. Загородній А. Г., Вознюк Г. Л., Смовженко Т. С. Фінансовий словник. - 2-ге видання, виправлене та доповнене. - Львів: Видавництво “Центр Європи”, 1997. 576 с.

Щербакова Т.А., к.е.н., доцент, Київський національний торговельно-економічний університет

\section{СТРАТЕГІЧНІ ПРІОРИТЕТИ НАЦІОНАЛЬНОЇ ЕКОНОМІКИ В УМОВАХ ГЛОБАЛІЗАЦІї}

Національна стратегія економічного розвитку України знаходиться в прямій залежності від світових тенденцій, неоіндустріальної трансформації промислового потенціалу, конкурентоспроможності, дії інноваційних процесів і висхідного розвитку. І для оздоровлення української економіки необхідна сильна, оновлена i модернізована промислова база, яка дасть можливість створити конкурентоспроможні підприємства у різних галузях національної економіки.

Вітчизняна промисловість повинна базуватися на новому фундаменті, що забезпечить іï комплексний розвиток з можливістю збереження традиційних галузей економіки так і формування нових високотехнологічних й конкурентних секторів економіки.

Зростаюча залежність національної економіки від зовнішніх факторів, в тому числі негативних, обмеженість і здорощення енергетичних ресурсів, необхідність більш раціонального використання сировинної бази і робочої сили мають служити стимулом для використання інновацій задля підвищення потенціалу віддачі від наявних в країні та імпортованих з-за іiі меж ресурсів, переходу вітчизняної економіки до стандартів економічно безпечного 
виробництва і споживання з метою забезпечення сталого економічного розвитку в цілому.

Світова наукова думка виділяє п'ять основних узагальнених стратегій, що можуть бути використані у здійсненні неоіндустріальних перетворень: імпортозаміщувальна індустріалізація; експортноорієнтована індустріалізація; індустріалізація, основана на ресурсах; експортні зони; індустріалізація через інновації.

Імпортозаміщувальна індустріалізація спирається на внутрішній ринок і зосереджується на виробництві готової продукції. Такий підхід можливий лише в країнах із значними внутрішніми ринками i здатністю правильно визначити джерела динамічних порівняльних переваг. Зважаючи на ситуацію в економіці світу та очікування на майбутнє, за висновками Конференції $\mathrm{OOH} з$ торгівлі і розвитку (ЮНКТАД), стратегія економічного розвитку, що спиралася на експорт, себе вичерпала. У нинішніх умовах доцільним є підхід, що орієнтує на стимулювання внутрішнього попиту, зумовлюючи тим самим розроблення та реалізацію політики, завдяки якій прискорення отримають види діяльності, характерні для національних товаровиробників, здатних випускати продукцію з порівняно високою питомою вагою доданої вартості. Країни досягнуть кращих результатів, якщо у своїх стратегіях щодо економічного зростання орієнтуватимуться на більш важливу роль підвищення попиту на внутрішньому ринку, підвищення заробітної плати, зміцнення державного сектора $i$, на додаток, - на задоволення попиту за рахунок розвитку внутрішнього виробництва в тих видах діяльності, які належать до переробної промисловості, - що особливо важливо. Віддача від них підвищується за рахунок "технологічної креативності", що з часом посилить і роль експорту.[1; с.8]

Найбільш очевидним інструментом даної стратегії є тарифи, однак тарифні заходи можуть бути обмежені і така стратегія може бути лише короткостроковою.

Ексопортноорієнтована індустріалізація спирається на експорт та диверсифікацію економіки. При цьому ця стратегія може починатися 3 експорту продукції низького рівня обробки з поступовим підвищенням в структурі експорту високотехнологічної продукції. Стратегія може спиратись і на проміжні продукти, дозволяючи зосередитися на частини виробництва, де вже існує порівняльна перевага.

Індустріалізація, що базується на ресурсах, є стратегією, яка може застосовуватися у разі, коли країна має значні обсяги сировини i потенціал для переробки цієї сировини на місцевому рівні для експорту. Головним інструментом в даному випадку є податок на 
експорт сировини, що знижує іiі внутрішню ціну. У вітчизняній практиці елементи цієї стратегії можна спостерігати до олієнасіння, металобрухту. Угода України про ЗВТ з ЕС передбачає поступове зниження ставок експортних мит 3 подальшим їх обнулінням. Експортні переробні зони повинні розглядатись як складова ексопортноорієнтованої індустріалізації.

Світовий досвід засвідчує, що незалежно від основної цільової стратегії: використання ресурсного потенціалу, імпортозаміщення чи експортна орієнтація, ії успішна реалізація може бути забезпечена лише за умови поєднання обраної стратегії зі стратегією індустріалізації через інновації.

Слід зазначити, що відмінністю цієї стратегії $€$ не тільки іï здатність поєднуватись 3 іншими моделями, забезпечуючи більш швидкий та тривалий ефект, але й те, що то дана стратегія реалізується заходами як на макрорівні так і на мікрорівні, і ключову роль в тіi реалізації відіграють підприємства. Саме бажання отримати більш високий прибуток, зміцнити конкурентні позиції, закріпитись на нових ринках $є$ мотивацією для здійснення підприємствами інноваційної діяльності.

Стратегія індустріалізації через інновації передбачає своєчасне впровадження сучасних засобів праці на заміну застарілих, застосування прогресивних форм та методів організації виробництва, дозволяє забезпечити більш високу ефективність виробництва.

Таким чином, для ефективного вирішення завдань неоіндустріальної трансформації вітчизняного промислового потенціалу та інтеграції в мережу світової економіки, Україні доцільно спиратися на комбінацію експортноорієнтованої та інноваційноспрямованої стратегії індустріалізації. Однак, слід зауважити, що на даному етапі розвитку промисловості, доцільно було б застосовувати політику протекціонізму, якщо це не суперечить укладеним міжнародним чи двостороннім угодам.

Значна увага питанням розвитку національної економіки саме на основі неоіндустріальної модернізації приділяється у монографії вітчизняних авторів B.I. Ляшенка та С.В. Котова «Україна XXI: неоіндустріальна держава або “крах проекту”?» [2]. У той же час існує ряд питань, пов'язаних 3 проблемами розвитку національної економіки, які потребують більш детальних досліджень. 


\section{Список використаних джерел}

1. Геєць В.М. Економіка України: ключові проблеми i перспективи / Геєць В.М. //Економіка і прогнозування. - 2016. - № 1. C. $16-25$.

2. Ляшенко B.I. Україна XXI: неоіндустріальна держава або“крах проекту"?: моногр. / В.І. Ляшенко, С.В. Котов; НАН України, Ін-т економіки пром-сті; Полтавський ун-т економіки і торгівлі. -Київ, 2015. - $196 \mathrm{c}$.

3. Стратегия Европы 2020 [Электронный ресурс]. - Режим доступа: http://ec.europa.eu/eu2020/index_en.htm. 


\title{
ТЕОРЕТИКО-МЕТОДОЛОГІЧНІ ТРАНСФОРМАЦІЇ ЕКОНОМІЧНОЇ НАУКИ У ХХІ СТ.: ПЕРСПЕКТИВИ НОВОЇ ПАРАДИГМИ
}

\author{
МАТЕРІАЛИ ВСЕУКРАЇНСЬКӦ̈ \\ НАУКОВО-ПРАКТИЧНОЇ КОНФЕРЕНЦЇ̈ \\ (Київ, 28-29 травня 2019 року)
}

Видавець і виготовлювач

Київський національний торговельно-економічний університет вул. Кіото, 19, Київ-156, Україна, 02156

Електронна адреса: econ-teor@ukr.net

Свідоцтво суб’єкта видавничої справи серія ДК № 4620 від 03.10.2013 р. 